



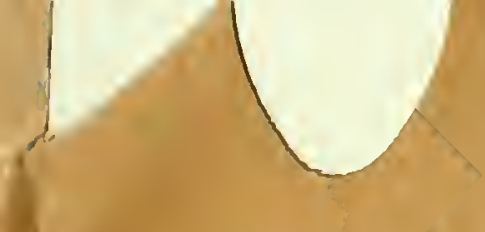

FAUNA

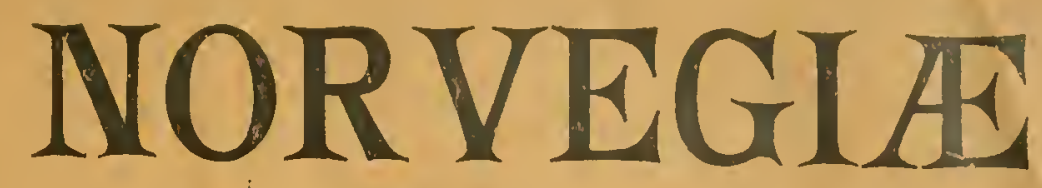

Bd. I.

BESKRIVELSE AF DE HIDTIL KIENDTE NORSKE ARTER

AF UNDERORDNERNE

\section{PHYLLOCARIDA 0G PHYLLOPODA}

\section{G. O. SARS}




\section{FAUNA}

\section{NORVEGI $\mathbb{E}$}

Bd. I.

BESKRIVELSE AF DE HIDTIL KJENDTE NORSKE ARTER

AF UNDLRORINERNE:

\section{PHYLLOCARIDA og PIYLLOPODA}

G. O. SARS 



\section{FAUNA}

\section{NORVEGI $\mathbb{E}$}

Vol. I.

DESCRIPTINS UF THE NURUEGIA SPEGIES AT PLESHAT KNOMN BEIONGING TO THE SIB-(MDERS

PHYLLOCARIDA AND PHYLLOPODA

$\mathrm{BY}$

G. O. SARS 



\section{FAUNA}

\section{NORVEGI}

Vol. I.

DESCRIPTIUNS OF THE NORTEGIAN SPECIES AT PRISENT RNOWN BELONGING TO THE SUBORIDERS

\section{PHYLLOCARIDA AND PHYLLOPODA}

BY

G. O. SARS 



\section{FORTALE.}

Nærværende Tærk, til hvis Udgivelse Staten liar hevilget de fornohe Miller, blev paalsegyndt tor mere end et Dexennimm siden; men forskjellige uforudseede Omstrendigheder har bevirket, at Udarbeidelsen af' samme $\mathrm{i}$ længere 'Tid har maattet standses, saa at forst nu Tærket kan ndkomme i sin Helhed. Oprindelig var Bevillingen givet til den fortsatte Udgivelse af Farma littoralis Norregice, livoraf tilligere er ndkommet 3 Bind, forfattede dels af min Fader alene, dels af ham i Forening med mu afdode Overlæge Danielssen og Konservator Koren. Da det forekom mig, at deme Titel paa en mindre heldig Maade vilde komme til at begrændse Stoffet, tillod jeg mig at foreslaa, at Benævnelsen 7ittoralis udgik og at Værket herefter sknlde nd komme muder den her anvendte 'Titel. Det af mig til nærværencle Bind valgte Stof er ogsaa af den Art, at det vanskeligt vilde passe indenfor Rammen af den tidligere Titel, da jo her ilke blot Sodyr, men ogsaa en Del rgte Ferskvandsdyr er omhandlede. Idethele syntes mig, at den mere omfattenrle Titel, Fama Nonegice, bedre matte knmne svare til sin Hensigt, da der lierunder vil kmme leveres Bidrag til Belysning af livilkensomhelst Branche af vor Fama, der maatte frembyde en særlig Interesse. I Overensstemmelse med de 3 udkomne Bind af Fauna littoralis, tror jeg at nærværende Værk bor indeholde Afhandlinger af en mere udforlig anatomisk-Jiologisk Character, hehandlende visse ndvalgte Dele af vor Fama og ndstyrede paa en saavidt muligt tidsmæssig Maade, saavel hvad Text som Plancher angaar. I et andet, paa engelsk skrevet Værk har jeg paabegyndt en Bearleidelse af vor Famna efter et lierfira temmelig forskjelligt Prin'ip, idet lette Værk er nærmest beregnet paa at
PREFACE.

The present work, for the publication of which the Government has granted the necessary funds, was begun more than ten years ago; but various unfureseen cireumstances having combined to put a stop to the preparation of the work for a considerable time, it is only now that it can be published in its entirety. The grant was originally given for the continned publication of Frana littoralis Norregice, of which three volumes had already been pnlilished, written partly by my father alone, partly by him in conjunction with the late Ir. Danielssen, and C'urator Koren. As it seemed to me that this title wonld limit the subject-matter' somewhat infelicitonsly, I ventured to suggest that the designation littoralis should be struck ont, and that the work should hereafter appear under the title here employed. The matter chosen by me for the present volume, is also of such a kind, that it conld hardly be inchuded under the former title, as not only marine animals, but also some true fresh-water animals are liere treated of. Upon the whole, it seemed to me that the more comprehensive title, Faune Norvegice. would better answer its purpose, as nuler it, contributions might be made to the information cuncerning any branch of our famma that might offer special interest. In accordance with the 3 published volnmes of Fama littoralis, I think that the present work should contain treatises of a more exhaustive anatomical-biological eharacter, dealing with certain parts of our fauna, and got up as far as possible in a manner suitalole to the times, as regards text and plates. In another work, written in English, I have begun an account of our fanma on a very different prineiple to this, as it is rather calculated to give, as far as possible, a brief', 
give en saavilt muligt kortfattet systematisk Oversigt af samtlige hidtil kjendte norske Arter, hvorved der er lagt hovedsagelig. Tægt para dets prak. tiske Anvendelighed red Artsbestemmelsen. mindre paa det ydre Uilstyr eller paa en mere indgaaende anatomisk Behandling af de enkelte Former. Jeg tror, at zoologiske Arbeider ularbeidede efter ethvert af disse Principer har sin fulde Berettigelse og Nytte Side om side, og skinle "grsaa af denne Trumd onske, at Fauma Norvegio hles forbeholdt mere ndtorlige Monographiner at enkelte mindre kjendte Dyreformer eller of legrændsede Grupper, der maatte frembrde en særlig Interesse i anatomisk-lbiologisk Henseende

Plancherne til nærværende Bind er $\mathrm{i}$ sin Tid ndforte paa nu aflode Lithograf Lynghs Officin, $\mathrm{og}$ ved deres Udforelse er anvendt al den Ombyrggeliglred og Kinnst, som da kunde præsteres, saavel hrad Lithographering som Farvetrykning angaar. Texten er i Lighed med de 2 sidste Bind af Fuma littoralis og med Nordhavs-Expeditionens Generalberetning, dobbeltspaltet, den ene Spalte norsk, den anden engelsk. Oversættelsen af de 6 forste Ark er besorget af nu afilode Translatem Wilson, Resten af Miss Jessie Muir.

Idet jeg herved fremlægger for Offentligheden 1ste Bind af Fauna Norvegire, sker det med det Haal, at der maa gives vore fremtidige Zoologer Anledning til at fortsætte dette Værk med flere paafolgende Bind udstyrede paa en for rort Land verdig Maade.

Forfatteren. systematic survey of all the hitherto known Norwegian speeies. whereby special importance is laid on its practical applicability in the determination of species, and less on its external get-np, or on a more detailed anatomical treatment of the varions forms. I think that zoological works written on these two principles are perfectly legitimate and useful side by side; and I therefore wish that Founc Norregice conld be liept for more detailed monugraphs on certain less familiar animal forms, or of limited groups that offered special interest in an anatomical-biological direction.

The plates to the present rolume were executed, in their time, in the late lithographer Lyngh's printing-office, and all the care and art of which that time was capable, both as regarls lithography and colonr-printing, were employed in their execution. The letter-press is similar to that of the last 2 volumes of Fauna littoralis, and to the General Report of the North Atlantic Expedition, being in two columns, the one colımn Norwegian, the other English. The translation of the first 6 sheets was made by the late $\mathrm{Mr}$. Wilson, translator, the remainder by Miss Jessie Mnir.

In now presenting the first volume of Fauna Norregise to the publie, I do so in the hope that opportunity may be given to our futnre zoologists to continue this work with successive volumes, got up in a manner worthy of our country.

The Author. 


\section{INDHOLD.}

Indledning .

Phyllocarida

Fam. Tebaliida

Gen. Nebalia, Leach

1. Teloalia bijes Falu.

2. Nalualia typhlops, (x. O). Sars.

Phyllopoda.

Sectio I. Anostrack

Fam. 1. Branchiporida .

Gen. Branchinecta, Verrill

Bramehinecta paludosa Müllurr)

Fam.2. Polyartemiida (ion. Polyartemia, Fischer

Polyartemia forcipata, Fischer

Sectio II. Notostraca

Fam. A podida

Gron. Lepidurus, Leach

Lejidlurus glacialis i Froyer

Sectio III. Conchostraca

Fam. 1. Limnadiida.

Gichl. Limnadia, Brogniart

Limmarlia lenticularis lin.). . . . . . $85^{\circ}$

Fam. 2. Limnetide . . . . . . . 116

Girn. Limnetis, Lovén . . . . . . . . . . 116

Limnetis brathyurus Mîll.)

Pag.
1.
4.
6.
7.
9.
31.
35.
39.
40.
40.
11.
58.
58.
59.
66.
67.
67.
68.
83.
84.
85
85.
116
116
117.

CONTENTS.

Introrluetion _. . _ _ . . . . . Pag. 1.

Phyllocarida.................4.

Fam. Tebaliida............ 0.

Gen. Nebalia, Leach . . . . . . . . 7 .

1. Nebalia hipes (Falur.). . . . . . . . . 9.

2. Tobalia typhlope, G. O. Sars . . . . . 31.

Phylloporla . . . . . . . . . . . . 35.

Section I. Anostraca . . . . . . . . . . . 39.

Fam. 1. Branchipodide. . . . . . . . 40.

Gen. Branchinecta, V'rrill . . . . . . . . 40.

Branchinecta paludosa Mïller) . . . . . . 41

Fan. 2. Polyartemiidae . . . . . . . . . 58.

tien. Polyartemia, Fischer . . . . . . 58.

Polyartemia furcipata, Fischer . . . . . . . 59.

Section II. Notostraca . . . . . . . . . 66.

Fam. Apodida . . . . . . . . . . . 67.

Gen. Lepidurus, Leach . . . . . . . . . . 47.

Lepidurus glacialis (Kroyer) . . . . . . . 68.

Section III. Conchostraca . . . . . . . . 83.

Fam. 1. Limnadiide . . . . . . . . 54 .

Gen. Limnadia, Brogniart . . . . . . . . . 8 ŏ.

Limnackia lenticularis lin.). . . . . . . . 85.

Fam. 2. Limnetida. . . . . . . 116.

Gen. Limnetis, Lovén. . . . . . . . . 116.

Limnetis brachyurus (Mïll.) . . . . . 117.

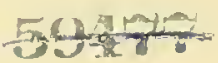

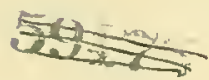





\section{INDLEDNING.}

Crustaceemes vidtloftige Classe inddeles, som behjendt, ialmindelighed i to store Afdelinger, Malacostraca, eller de hoier'e Krebsdyr, og Entomostraca, eller de saakaldte Smaakrebse. Enlver af disse Afdelinger lader sig igjen dele i 4 Grupper eller Ordener. Til den forste horer 1) I'odophthalmata, eller de stilkoiede Krebse (Decapoda, Schizopoda og Stomatopoda), 2) Cumacea, 3) Isopoda og 4) Amphiporta; til den siclste: 1) Branchiopoda, 2) Ostracoda, 3) Cirripatia, og 4) Copepoda. Hertil kommer endnu den $\mathrm{i}$ mange Henseender meget anomale, og $\mathrm{i}$ visse Punkter med Arachniderne beslægtede Gruppe, Tiphosw:e, eller Dolkhalerne, som dog af flere Naturforskere ikke henregnes til Crnstaceerne, men betragtes som Typen for en egen Arthropodeclasse. Naar undtages denne sidste Gruppe, er alle de orrige ovenanforte Ordener vel repræsenterede $\mathrm{i}$ vor Fauna. For det forste vil vi alene komme til at beskjæftige os med den forste af de til Entomostraceerne horende Ordener; Branchiopoda. Deme Orden har faaet sit Navn deraf, at et storre eller mindre Antal af de bag Munddelene folgende Lemmer antager en eiendommelig bladdammet Structur, der gjør dem fortrinlig skikicede til at fungere som Respirationsorganer, om de end i enkelte Tilfælde paa samme Tid kan fungere som Srommeapparater. Undertiden, saaledes los visse Cladocerer, kan disse Lemmers saavel respiratoriske som motoriske Function være meget rednceret, luvorimod de faar sin væsentligste Betydning som Griberedskaber, der understotter Munddelene ved at fastholde og bringe ti] Munden de Fodemidler, hvoraf disse Dyr lever, en Function, som imidlertid ogsaa for en Del kan paavises hos Former med forovigt normalt udviklecte Branchialfodder, f. Ex. Apus. Ogsaa hos fuld1 - R. 0. Sars: Famn Vorregia.

\section{INTRODUCTION .}

As is known, the extensive class Crustacea is, in general, classified into two great divisions viz., Malacostraca, or the higher Crustaceans, and Entomostraca, or the so-called lower Crustaceans. Each of those divisions may be subdividerl, again, into $\neq$ groups or orders. To the first division pertain: - 1) Podophthulmate oi the stall-eyed Crustaceans (Decapods, Schizopods and Stomapods), 2) Cumacea, - 3) Isoporla, and - 4) Amphiporla. To the second division pertain: - 1) Branchiopoda, 2) Ostracoda, - Cirripertia, and - 4) Copeporla. To them is added the Kiphoswre, or sword-tails - in many respects very anomolous, and in certain character's relat d to the gromp Arachuida - which are by several naturalists, lowever, not assigned to the Crustaceans, but is considered to be the type of a special class af Arthropods. With the exception of that last-named group all the other abovementioned orders are well represented in the Norwegiar Fainuia. At present we shall only occupy ourselves with the first of the order's pertaining to the Entomostracans riz: Branchiopoda. This order has obtained its appellation from the circumstance, that a larger or smaller number of the appendages behind the oral parts assume a peculiar foliaceous structure, which canses them to be admirably adapterl to serve as respiratory organs, even although they, in a few cases, may at same time serve as swimming apparatuses. Occasionally, as in certain Cladocerans, both the respiratory and motoric functions of these appendages may be greatly diminished; and their essential importance becomes that of a prehensile-apparatus which aids the oral parts in securing and carrying to the mouth the nutriment upon which these animals feed; a function which 
kommen typiske Branchiopocler ril ri finde, at Lemmerne. ved Siden af sin Function som Respinationsorganer, altid er af væsentlig Betydning for Tilveiebringelsen af Follen, idet de ved sine rythmiske Bevægelser frembringer en continuerlig Stronning af Vandet ind mod Hunden, hrorved de Smaapartikler, hroraf Dyret lever, bringes indenfor Munddelenes Omraade. I ethvert Fald maa den orenomtalte eiendommelige Modification af Lemmerne, hvortil ri egentlig ikke har noget tilsvarende hos andre Crustaceer, betragtes som den for de her omhandlede Dy' rigtigste og mest udprægede Character.

Branchiopoderne indtager i flere Henseender en central Stilling inden Crustaceernes Classe, og Prof. Clans har endog fremsat den Hypothese, at alle nulevende Crustaceer $i$ sidste Instans nedstammer fra en phyllopodeagtig Iyreform (Protophyllopod). Skjondt denne Hypothese af andre Zoologer (Packard) har været bestridt, er der dog al Grund til at antage, at disse Dyr har conserveret adskillige Characterer, der efter al Sandsynlighed er' i hoi Grad primitive og maaske endog skriver sig fra de ældste paa vor. Klode optrædende Arthropoder. Allerede det i hoi Grad varierende og ofte excessivt forogede Antal Kropssegmenter, samt disses ialmindelighed mindre skarpt ndprægede Gruppering til distincte Kropsafsnit, synes at vise, at vi her har at gjore med Former af en kum lidet ndarbeidet Character, los hvem endnu ikke det for Nutidens Crnstaceer typiske Forhold rigtigt har frestnet sig; og hrad Lemmernes Bygning angaar, saa er vel alle enige i at de, ialfald hos de typiske Branchiopoder, repræsenterer et mere primitivt Standpunkt end hos nogen af de ovrige Crnstacegrupper. Ogsaa hrad den indre Organisation angaar, findes hos de herhen horende Folmer kun lidet fixerede For'lold, men derimod en Mangfoldighed af Modificationer i Bygningen af snart sagt alle Organer, hvad der ligeledes giver denne Crnstacegruppe et ganske eiendommeligt Præg ligeoverfor de ovrige Ordener. Endelig vil vi i disse Dyrs Leveris, Forplantning og Udrikling stode paa baade characteriske Forskjelligheder mellem de forskjellige Former og tildels ogsaa hoist eiendommelige, fra samme hos andre Crustaceer afvigende Forhold. Et noiere Stndinm af deme Crustacegruppe ril derfor ogsaa være af særlig Interesse, saavel i phylogenetisk som biologisk Henseende og vil passende liunne tjene som Udgangspunkt red Bearbeidelsen af den her ombandlede Drrclasse. may also, to some extent, be demonstrated in forms with otherwise normally developed branchial-legs e. g. Amus. Also in perfectly typical Branchiopods we may observe that the appendages, besides their function as respiratory organs, are always of material importance in the procuring of the nutriment, as they by their rhythmical morement produce a continuous current of the water in towards the mouth. by which the minute particles upon which the animal exists are brought within the range of the oral parts. At any rate, the above mentioner? peculiar modification of the appendages, to which we meet with nothing really correspondent in other Cristaceans, must be considered to be the most important and prominent characteristic of the ani mals here spoken of.

The Branchiopods occupy, in several respects, a central position in the class of the Crustaceans, and Prof. Clans has even proposed the hypothesis, that all the now-existent Crustaceans may descend, in the final instance, from a plyllopodons animal-form (Protophyllopod). Althongh that hypothesis has been rejected by other zoologists (Packard), there is still every reason to assume that those animals have retained several characteristics which are, in all probability in a high degree primitive, and perhaps eren emanate from the oldest Arthropods that have appeared on our Earth. The extremely variable and frequently excessively increased number of bodr-segments, as well as in general their less distinctly prominent grouping into distinct sections, at once appear's to point to the circumstance that we have here to do with forms of only vaguely developed character, in which the typical features characteristic of the modemly existent Crustaceans, have not yet become permanently established: and as regards the structure of the appendages all unite, we believe, in the opinion that it. at any rate in the typical Branchiopods, represents a more primitive condition than in any of the other groups of Crustaceans. Also in regard to the internal or ganization there is found, in the forms belonging to this order, only little of permanent features but, on the other hand, a multitude of modifications in the structure of, it may be said, all the organs. a circumstance that also imparts to this group of Crustaceans a quite peculiar imprint compared with the other orders. Finally we meet in these animals' mode of life. propagation and development. both characteristio differences between the various forms and partly, also, highly peculiar features differing from those in other Crustaceans. A closer study of this group of Crustaceans, will, therefore, prove of special interest, both in phrlogenetic and biological respects, and will serve as a suitable point of departure in the treatment of the animal. class here spoken of. 
Branchiopodernes Orden lader sig naturligt inddele i 4 underordnede Grupper, eller Underordener, der saavel hvad den ydre Habitus som den anatomiske Bygning angaar, skiller sig temmelig skarpt fra hinanden. Disse Underordener er folgende: 1) I'hyllocarita, 2) Phyllopoda, 3) Cladocera og 4) Branchiura. De 2 forste af disse Underordener vil blive gjorte til Gjenstand for en nøiere Behandling i nærværende Bind af Fauna Norvegice.
The order of Branchiopods may be naturally divided into 4 subordinate gromps or sub-orders, which, both in regard to external habitus and anatomical structure, distingnish themselves pretty sharply from each other. These sub-orders are, as follows viz: 1) Phyllocarida, - -2) Phyllopoda, 3) Cladocera, and - 4) Branchiura. The two firstnamed sub-orders will be made the subjert of a closer treatment in the present volume of Fauna Norvegice. 
Subordo I.

\section{PHYLLOCARIDA}

\author{
(Leptostraca, Claus).
}

Character. - Branchiopoder med den forreste Del af Legemet dækket af et stort, mere eller mindre ndpræget tveklappet Rygskjold, forsynet fortil med en bevregelig Pandeplade. Den bagre Del af Kroppen cylindrisk, afsmalnende bagtil $\mathrm{og}$ endende med 2 bevægelige Grene (Furca), mellem hrilke der undertiden er en lolkformig Haleplade. Oinene stilkede og bevægelige. Begge Par Folere vel udvililede, mangeleddede, 2det Par enkle, hverken locomotoriske eller prehensile. Alle Forkropslemmer bag $1 l u n d-$ delene udelukkende respiratoriske; Bagkropslemmerne meget ulig disse og fordetmeste locomotoriske, manglende paa de bagerste Segmenter. Havdyr.

Alm. Bemærkninger. - Typen for denne Underorden er den i mange Henseender hoist mærkværdige og anomale Slægt Nebalia, on hris systematiske Stilling der har hersket den storste Uenighed blandt Zoologerne. ILedens man for ialmindelighed med Vilne-Edwards henregnede denne Form til Phyllopoderne, har $i$ den nyere Tid, narnlig efter de af Prof.Clans anstillede Undersogelser, en ganske anden, allerede meget tidligt af enkelte Naturforskere ytret Opfatning vundet Overhaand, nemlig at denne Form slntter sig nærmest til de stilkoiede Krebsdyx, navnlig til visse Schizopoder (Enphausiidæ), og at den saaledes snarere tilhorer Malacostraceernes Afdeling end Entomostaceerne. Jeg har paa et andet Sted ${ }^{1}$ ) nærmere udviklet mine Grunde til fremdeles at bibeholde denne Slægt muder Entomostraceerne, og blandt disse er Branchiopoderne de, hrormed nær-

Report on the I'hyllocurila, collected during the Expedition of H. AI. S. challenger

\section{Sub-Order I. \\ PHYLLOCARIDA}

\author{
(Leptostraca, Claus).
}

Characters. - Branchiopods, with the foremost portion of the body covered by a large, more or less distinctly bi-lobate carapace, furnished anteriorly with a mobile frontal plate. The posterior portion of the body cylindrical tapering backwards, and terminating in 2 mobile rami (furea), between which there is occasionally a mucroniform caudal plate Eyes peduneulated and mobile. Both pairs of antennæ well developed, multiarticulate; 2nd pair simple, neither locomotory nor prehensile. All the appendages of the anterior division of the body behind the oral parts, exclusively respiratory. The appendages of the posterior division of the body rery unlike the former and chiefly locomotory; absent on the posterior segments. Narine animals.

General remarks. The type of this sub-order is - the in many respects highly remarkable and anomalous genus - Telalia, regarding whose systematic position the greatest difference of opinion has prevailed among zoologists. Whilst, previously. zoologists in general agreed with Milne-Edwards in assigning this form to the Phyllopods, there has prevailed in later times, especially since the result of the investigations made by Prof. Claus, a quite different opinion, which already mush earlier was expressed by a fer naturalists, riz: that this form approximates closest to the stalk-eyed ('rustaceans, especially to certain Schizopods (Euphansiidæ), and that it, therefore, pertains rather to the Halaco. stracan than to the Entomostracan division. I have elsewhere ${ }^{1}$ ) explained, in greater detail, my reasons for still retaining this genus under the Entomo-

Report on the Phyllorrida collected during the Expledition of $\mathrm{H}$. M. S. Challenger. 
værende Form viser mest Afinitet. At den imidlertid ikke længere kan opfattes som en virkelig Phyllopode, derom kan der vel neppe for Tiden rære mere end en Mening, efterat dens anatomiske Bygning, navnlig ved Prof. Clans's udmærkede Undersogelser, er bleven noiere udredet. Sporgsmaalet er nn, om de Eiendommeligheder, denne Form viser i anatomisk Henseende, gjor det absolut nolvendigt at skille den helt nd fra de orrige Entomostraceer som Typen for en egen Orden. Saagodtsom samtlige Forskeve synes for Tiden i Virkeligheden at være af denue Mening, og baade Packard's Benærnelse Phyllocarida $\mathrm{og}$ den af Claus foreslaaede Leptostraca er beregnet paa at udtryklie en distinct Orden. Undersoger vi imidlertid, lvorledes Forholdet er med de for Tiden ialmindelighed til Branchiopodernes Orden henforte Former, saa vil vi ogsaa her stode paa særdeles store og væsentlige Forskjelligheder i den anatomiske Bygning; ja de saakaldte Branchiurer (Argulus), som vel de fleste Forskere nu er enige om at henfore til Branchiopodernes Orden, forekommer mig endog, saavel hvad den ydre Habitus som den indre Organisation og Levevis angaar, at skille sig endun betydelig mere fra de typislie Branchiopoder encl Tilfældet er-med Nebalia. Hos denne sidste Slægt ex der ialfald en Character, og det netop den for Branchiopodernes Orden mest betegnende, der staar i den bedste Harmoni med hvad vi finder som typiskt for denne Krebsdyrgruppe; jeg mener Forkiopslemmernes Bygning. Disse viser ikke blot ved sin udpræget bladdannede Form den storste Lighed med samme hos virkelige Branchiopoder: men, hvad der er af end storre Vægt, deres respiratoriske Function el fuldkommen ligesaa tydeligt udpræget som hos de mest typiske Former blandt hine. Alene denne ene Character synes mig at maatte stemple Slægten Nelualia som en reritabel Branchiopode, og ialfald at vare af adslillig storye Vrgt end Mesteparten af de Characterer, man har anfort for at molbevise en saadan Antagelse, og hvoraf flere falitisk er fuldstændig nbrugelige. Efter min Mening bor derfor. Slægten Nebalia henfores til Branchiopodernes Orden, on den end her maa danne Typen for en egen. i visse Henseender meget anomal Afdeling eller. Underorden, for hrilken den forst af Packard foreslaaede Benævnelse Phyllocarida vil kunne bibeholdes.

I den nyere Tid har man troet i nogle, tildels kjæmpemæssige, fossile For'mel fra den palæuzoiske Formation (Ceratiocaris, Dithyrocaris etc.) at gienkjende visse for Slægten Nebalia eiendommelige Characterer, saaledes Legemets almindelige Form, Udviklingen af Rygskjoldet og navnlig den meget characteristiske herægelige Pandeplade; og; skjondt stracans, and among these the Branchiopods are those with which the present form exhibits most affinity. That it may, however, be no longer regarded as a genuine Phyllopod, there can, now be scarcely any diversity of opinion since its anatomical structure has been precisely elncidated, especially through Prof. Clans's admirable investigations. The question now is, whether the peculiarities this form exhibits in anatomical respects makes it absolutely neccessary to separate it entirely from the other Entomostracans, as the type of a special order. Nearly all investigators appear, at present, to really entertain that view, and both Packard's appellation, Phyllocarida, and that proposed loy Claus, Leptostraca, ale intended to express a distinct order. If we, how ever, investigate what the relations of the forms at present generally assigned to the order of Branchiopods are, we will also here meet with particularly great and material divergencies in the anatomical structure; indeed the so-called Branchima (Argulus), which most investigators are now, we think, unanimous in assigning to the order of Branchiopods. yet appears to me, both in regard to external habitus, internal organization, and the mode of life, to distinguish itself even more considerably from the typical Branchiopods than is the case with Nebalia In the latter genus there is, at any rate, one char acter, and just the one most characteristic of the order of Branchioporls, which stands in the most perfect harmony with what we find to be typical in that group of Crustaceans. I refer here to the structure of the appendages of the anterior division of the body. These exhihit, not only in their distinguished foliaceous form the greatest similarity with the same limbs in genuine Branchiopods, bnt what is of still greater importance, their respiratory function is perfectly as prominent as in the most typical form of Branchiopods. That single characteristic alone, it appears to me, must stamp the gemus Nebalia as a true Branchiopod, and, in any case, is of considerably more importance than the greater part of the characteristics that have been adduced to disprove such an assumption, and some of which are really perfectly unserviceable In my opinion the genus Nebalia ought, therefore, to be assigned to the order of Branchioporls, even although it hele must form the type of a special, in certain respects rery anomalons division or suborder, for which the appellation Ihyllocarida, first proposed by Packard, may be retained.

In later times it has been thought, that we, in some partly gigantic fossil forms from the Paleozoic formation (Ceratiocaris, Dithyrocaris ic.) were able to recognize certain characteristics peculiar to the genus Nebalia, for instance the general form of the body, the development of the carapace, and especially the very characteristic mobile frontal 
disse Formers Organisation fororrigt kun er yderst ufuldstændigt kjendt (endmu har man saaledes ingensomhelst Kjendskab til Lemmernes Beskaffenhed hos disse Former), har Packard nylig indbefattet dem under samme Gruppe (Orden) som Vebalia. Uagtet jeg for flere af disse fossile Formers Vedkommende anser det for meget trivlsomt, hrorvidt de lader sig henfure til denne Gruppe, har jeg dog forsogt at give den ovenstaaende Diagnose af Underordenen en saavidt rummelig Character, at de nærnte fossile Former til Nod lader sig indbefatte nuder samme. De faa hidtil kjendte levende Former horer ntvivlsomt alle til en og samme Familie," der passende vil kumne benævnes efter den forst opstillede og derfor typiske Slægt. plate; and although the organization of those forms is, otherrise, extremely imperfectly known (we have, for instance, not the slightest knowledge of the nature of the appendages in those forms), Packard has lately included them in the same gromp (order), as Tebalia. Although I, in regard to several of those fossil forms, consider it very doubtful whether they can be assigned to that gronp, I have yet endeavoured to give the above diagnosis of the sub-order such a broarl character, that the fossil forms referred to, may, if necessary, be included in it. The few hitherto known living forms all belong, nudonbtedly, to one and the same family, which may suitably be named after the first established and therefore typical genus.

\section{Fam. Nebaliidæ.}

Character. - Legemet mere eller mindre forlænget, successivt afsmalnende bagtil, nden skarpt markeret Begrændsning mellem For- og Bagkrop. Rygskjoldet kun lelt fortil umiddelbart forbundet med Legemet, sammentrykt, treklappet, Valvleme bevægelige og sammenholdte ved en tydelig Adductormuskel; Pandepladen tungedamet, forbundet med Rygskjoldet ved et tydeligt Led. Truncus lost overdækket af Rygskjoldet og delt i 8 fuldstændige Segmenter af ens Udvikling. Bagkroppen bestaaende af 2 mere eller mindre tydeligt begræudsede Afsurit, brert sammensat af 4 Segmenter. Oinene fæstede tæt sammen under Basis af Pandepladen og divergerende til hver Side. Begge Par Folere kraftigt udviklede, snbpediforme, Skaftet dobbelt knæboiet, Sroben mangeleddet; de ovre med et lamelleformigt børstebesat Vedhæng ved Enden af Skaftet. Kindbakkerne forholdsvis smaa, men med vel ndviklet Palpe; Tyggedelen hovedsageligt repræsenteret af Molarprocessen. 1ste Par Kiæver merl 2 indadrettede Tyggelappe og en lang, borsteformig, bagndrettet Palpe; 2det Par lamellære, med mere eller mindre udviklet Palpe og Exognath. \& Par mere eller mindre udpræget bladdamede, respiratoriske Lemmer tilstede paa Eorkioppen, bestaaende af Endo-, Exoog Epipolit, den forste mere eller mindre forlænget, med Inderkanten tot borstebesat, men nden tydelige Enditer eller Flige De + forreste Par Bagkropslemmer omformerle til kraftige, tregrenede Svommefodder; de 2 folgende Par rudimentære. De 2 sidste Segmenter uden Buglemmer. Halegrenene simple, lineære eller lamellære, tæt borstebesatte

\section{Fam. Nebaliidæ.}

Characters. - Body more or less prolonged, tapering backwards gradually, withont sharply defined demarcation between the anterior and posterior divisions. Carapace attached, only quite in front, immediately to the body, compressed, bilobate, the valves mobile and kept together by a distinct addnetor muscle. Frontal plate linguiform, attached to the carapace by a distinct joint. Truncus loosely covered by the carapace and divided into 8 perfect segments of uniform derelop. ment. The posterior division of the body consisting of 2 more or less distinctly defined sections, each composed of 4 segments. Eyes secured close together below the base of the frontal plate, and divergent to each side. Both pairs of antennæ powerfully developed, subpediform, peduncle double-geniculated, flagellum multiarticulate; the superior ones with a lamelliform setous appendage at the extremity of the peduncle. Mandibles relatively small, but with well developed palp; the masticatory part represented chiefly by the molar expansion. First pair of maxillæ with two inwardly directed masticatory lobes and a long setaceous palp directed backwards; 'nd pair lamellar with more or less developed palp) and exognath. Eight pairs of more or less prominently foliaceous respiratory appendages present on the anterior division of the body, consisting of endo-, exo-, and epipodite; the first more or less prolonged, with the inner edge closely beset with bristles but withont distinct endites or laps. The $t$ foremost pairs of appendages of the posterior division of the body transformed into 
ved Spidsen og i Inderkanten. Ingen median Haleplade tilstede. Den indre Organisation nærmest lig samme hos Amphipoderne. Eggene gjennemgaar sin Udvikling indenfor Rrgskjoldets Valvler, mellem Forkroppens Branchialfodder. Ungens Udvikling directe, uden Metamorphose.

Bemærkninger. - Indtil for ganslie nylig kjendte man af nærræende Familie kun en eneste Slægt nemlig Slægten Nebalia. Under Challenger-Expeditionen blev imidlertid opdaget 2 herhen horende Former, der begge danmer Typer for særskilte Slægter og narmere er omtalte $\mathrm{i}$ min Bearbeidelse af de under denne Expedition indsamlede Phyllocarider. Begge disse Slægter udmærker sig red den eiendommelige Udvikling af Branchialfodderne. Medens disse hos den ene Slægt, Paranebalia Claus, er, navnlig hos Hunnen, ualmindelig stærkt forlængede, saa at de $\mathrm{i}$ visse Henseender selv minder om Forkropslemmerne hos visse Schizopoder (Euphausiidæ), er de hos den anden Slægt, Tebaliopsis G. O. Sars, reducerede til meget smaa, utydeligt lappede, membranose Plader, der viser endnu mindre Lighed med sædvanlige Fødder end hos de mest typiske Branchiopoder. Den 3die Slægt, Nebalia, staar i Henseende til Branchialfoddernes Udrikling paa en Naade midt imellem hine "2 Slægter og repræsenterer. saaledes det for Familien typislie Forhold. I Henseencle til den ovrige Organisation synes der ikke at være synderlig stor Forskjel mellem de 3 Slægter, omend man ogsaa her forefinder Characterer af utvivlsom generisk Betydning. Alene den typiske Slægt, Tebalia, er representeret $\mathrm{i}$ ror Fama.

\section{Gen. Nebalia, Leach.}

Slægtscharacter. - Rygskjoldet stærkt sammentrykt, bagtil i Midten dybt indbugtet. Sidelappene af betydelig Storrelse, bredt afrundede og dækkende næsten hele det forreste Afsuit af Bagkroppen. Pandepladen smalt tungeformig, med eller uden terminal Spina. Truncus forholdsvis kort. Bagkroppen betydelig længere end Forkroppen, jernt afsmalnende bagtil, nden skarp Begræudsning mellem det forreste og bagerste Afsnit. Oinene mere eller mindre ndviklede, hvert red Basis dækket af en tilspidset, slijalformig Plade De ovre Folere liortere end de nedre, Skaftet 4-leddet, med en stærls knæformig Boining mellem 2det og 3die Led; sidste Led noget udvidet mod Enden og lobende fortil ud i et liort, powerful bifurcate swimming legs; the 2 snceeding pairs rudimentary. The 2 last segments without any ventral appendages. Candal rami simple, linear or lamellar, closely beset with bristles at the tip and on the inner edge. No medial candal plate. Internal organization approximating elosest to that of the Amphipods. The ova mndergo their development inside the valves of the carapace, between the branchial legs of the anterior division of the body. The derelopment of the young direct, without any metamorphosis.

Remarks. - Until ruite lately we knew only a single genus of this family riz., the genus Nebalia. There were collected on the Challenger Expedition, however, 2 forms pertaining to the family, which both form types of special genera, and are more particularly described in my Report of the Phyllocarida collected by that Expedition. Both of those genera distinguish themselves by the peculiar derelopment of the branchial legs. Whilst these in the one genus, Iaranebatia, Clans, are, especially in the female, unusually greatly prolonged, so that in certain respects they even remind one of the appendages of the anterior division of the body in certain Schizopods (Euphansiidæ), they are in the other genns, Nebaliopsis, G. O. Sars, reduced to very small, indistinctly lobate membranous plates that show still less resemblance to ordinary legs than in the most typical Branchiopods. The 3rd genus, Nebatia. stands, in regard to the development of the branchial legs, in a manner intermediate between those two genera. and thus represents the relation that is typical of the family. In regard to the rest of the organization there does not appear to be any material difference between the 3 genera, although we, here, also find characteristics of indubitable generic importance. Only the typical genus, Telatia, is represented in the Norwegian Fauma.

\section{Gen. Nebalia, Leach.}

\section{Generic characters. - Carapace greatly com-} pressed, deeply insinnated in the middle posteriorly, the lateral lobes of considerable size, broadly rounded and covering nearly the entire front section of the posterior division of the body. Frontal plate narrow linguiform, with or withont terminal spina. Truncus relatively short. The posterior division of the body considerably longer than the anterion division, tapering evenly backwards, without sharp demarcation between the foremost and hindmost sections. Eyes more or less dereloped, each covered at the base by an acuminate squamifor'm plate. Superior antennæ shorter than the inferior ones; peduncle 4-jointed with a strong geniculate bend 
simpelt triangulært Fremspring; det lamelleformige Verlhæng ovalt, tæt haaret; Sroben hos Hamnen mere forlænget end hos Humnen og forsynet med talrige krandsformigt stillede Sandseborster. De nedre Folere med Skaftet 3-leddet, 2det Led red Enden fortil gaaende nd i et kort tandformigt Fremspring og dannende med sidste Led en knæformig Boining; Sroben hos Hannen overordentlig tynd og forlænget. Kindbakkernes Palper meget store, 3-leddede, sidste Led sammentrykt, lineært, stumpt tilrundet $\mathrm{i}$ Enden og tæt borstebesat langs Inderkanten. 1ste Par Kijæver med begge Tyggelappe korte, den yderste bredest, Palpen stærkt forlænget, besat med lange stire Borster; 2det Par med vel nuviklet 2-leddet Palpe og smal elliptisk Exognath. Branchialfodderne ganslie dækkede af Rygskjoldets Valvler; Endopoditen jevnt afsmalnende mod Enden, hos Hmmen stærkere forlænget end hos Hannen samt ved Spidsen besat med lange, cilierede Borster; Exopoditen lamelleformig, bredt oval; Epipoditen meget stor, platleformig, saavel oventil som nedentil nddraget til en lamellær Lap. Svommefodderne kraftigt ndviklede, den ydre Gren kortest og i Yderkanten heræbnet med stærke Torner, den indre smalt lancetformig. Halegrenene lineære, stærkere forlængede hos Hannen, tæt borstebesatte langs Inderkanten og i Spidsen.

Bemærkninger. - Fra de 2 oremnærnte Slægter, Paranebatia og Nebaliopsis, er nærrærende Slægt, foruden ved Branchialfoddernes forskjellige Udseende, blandt andet characteriseret ved Rygskjoldets Form, som navnlig hos Slægten Nebaliopsis er temmelig afvigende, fremdeles ved de eiendommelige skjælformige Øienplader, red Folernes Bygning og navnlig disses eiendommelige Udvikling hos Hannen, endelig red Kjærernes Bygning. Ogsaa i det indbyrdes For'lold mellem de forskjellige Kropsafsnit er der characteristiske Ditferentser mellem de 3 Slægter. Man kjender for Tiden med Sikkerhed kim ״․ Arter af denne Slagt, som begge forekommer hos os og nedenfor vil bive noiere beskrevne ${ }^{1}$ ).

Den af Thounson (Ann. Yat. Hist. Ser. 5. Vol. 4', fra Jew Zeeland anforte $\boldsymbol{T}$. longicornis tor dog, efter Lokaliteten at domme, rejrasentere en egeu Art. Det afbildeile Ex emular, en fulıt udviklet Hau, ligner imidlertid serdeles neget Hannell af vor $\mathbf{N}$. lipes. between the 2nd and 3rd joints; last joint somewhat expanded towards the extremity and, anteriorly, produced to a sliort plain triangular projection; the lamelliform appeidage oval, densely hirsute; flagellnm in the male more prolonged than in the female, and furnished with mumerous verticilate sensory bristles. Inferior antennæ with the pednncle 3-jointed, 2nd joint, at the anterior extremity, prodnced to a short dentiform projection, and forming with the last joint a geniculate bend; flagellum in the male extremely slender and prolonged. IIandibular palps very large, 3-jointed, last joint compressed, linear, bluntiy rounded at the extremity, and closely beset with bristles along the inner elge. First pair of maxillæ with both masticatory lobes short, the outer one broadest, palp greatly prolonged, beset with long stiff bristles; ?nd pair with well developed 2-jointed palp and small elliptical exognath. Branchial legs quite covered by the valves of the carapace, the endopodite diminishing uniformly towards the extremity, more prolonged in the female than in the male, and at the extremity beset with long ciliated bristles; the exopodite lamelliform, broadly oval; the epipodite very large, lamelliform, drawn ont above and below to a lamellar lappet. Natatory legs powerfully dereloped, the outer ramus shortest and on the onter margin beset with strong spines; the inner ramus narrow lanceolate. Caudal rami linear, more prolonged in the male, closely beset with bristles along the inner eige and at the tip.

Remarks. - The present genus is, besides by the different appearance of the branchial legs; among other things distinguished from the 2 above-mentioned genera, Paranebalia and Nebaliopsis, by the form of the carapace, which, especially in the genus Telualiopsis is pretty different; further, by the peculiar squamiform ocular plates, the structure of the antennæ and especially their pecnliar development in the male, and finally by the structure of the maxillæ. In the mutual relations, also, betreen the various sections of the body, there are characteristic divergencies between the 3 genera. At present we know, with certainty of only 2 species of this genus, both of which belong to the Norwegian Fauna and will be more particularly described in the sequel ${ }^{1}$ ).

\footnotetext{
) Tongicomis mentioned by Thomson, from New Zealand (Anu. Nat. Hist. Ser. 5, Vol. 4) may, howerer, juclged by its locality, represent a distinct species. The specimen illustrated, a fully developed male, resembles, however, very greatly the male of the northern $\mathbf{T}$. bipes
} 


\section{Nebalia bipes (Fabr).}

(Tab. I, Fig. 1-3; Tab. II og IlI; Tab. IV, Fig. 1-8; Tab. V).

Cancer bipes, O Fabricins, Fauna Grönlandica n. 223.

Cancer gamarellus bipes, Herbst, Geschichte der Krabhen etc. II, III.

Nebalia Herbstii, Leach, Zool. miscell. I, p. 100.

IIiIne-Edwards, Hist. nat, des Crustacés. III p. 356.

Nebulia Montagui, Thompson, Zool. Researches.

Telaliu bipes, Kroyer, Gronlands Amphipoder, p. 91.

- $\quad$ - Naturh. Tidsskr. 2den Række, II, 1. 436.

- _ Gaimard's Voyage en Scandinavie, I'l. 40, Fig. 2, $\mathrm{a}-\mathrm{x}$.

- - Baird, British Entomostraca.

Nobalin Geoffroyi, Milne-Edwards, Ann. d. sc. nat. I82s.

- - II-Edwards, Hist. nat. d. Crustacés. III.

- $\quad$ - Clans, Zeitschr. f. wissensch. Zoologie, XXII, p. 323, Tab. XXV.

- Claus, Untersuchungen zur Erforschung der genealogischen Grundlage des Crustaceensystems, p. 2t, Tab. XV, Fig. 4-6.

Nebalia bipes, A. S. Packard, A Monograph of the Phyllopod Crustacea of North America, with Remarks on the Order Pbyllocarida, p. 432, PI. XXXVIIXIVII.

Artscharacter. - Legemet af temmelig slank Form, uavulig hos Hannen. Rygskjoldet af betydelig Storrelse, seet fra Siden hos Hunnen af oval, hos Hannen af elliptisk Form, omtrent lige hoit fortil som bagtil. Pandepladen jevnt tilrundet i Enden, uden terminal Spina. Oinene vel ndviklede, noget sammentrylite, med den ydre Del noget ndvidet og skjævt afrundet, Pigmentet af morkerod Farve. De ovre Folere hos Humen omtrent af Forkroppens Længde, med Svoben omtrent saa lang som Skaftet og det lamelleformige Vedhæng ovalt; hos Hannen betydelig stærkere forlængede, med Svoben mere end dobbelt saa lang som Skaftet og det lamelleformige Vedhæng smalt elliptiskt. De nedre Folere hos Hmnen 1/2 Gang til saa lange som de ovre; hos Hannen af bele Legemets Længde, med Svoben overordentlig tynd og forlænget. Branchialfoddernes Epipodit meget stor, elliptisk, med den nedre Lap af samme Storrelse som den ovre. 1ste Par Svommefodder med Yderkanten af den ydre Gren tandet i hele sin Længde. Halegrenene hos Hunnen omtrent saa lange som de 2 silste Bagkropssegmenter tilsammen, hos Hannen af mere end den dobbelte Længde. Farven varierende fra lyst lividgult til intensiv rodbrun. Legemets Længde indtil $12 \mathrm{~mm}$.

Bemærkninger. - Den middelhavske Form, N. Geoffroyi, M. Edw., hvoraf jeg har havt Exemplarer til Undersogelse, tagne af min Farler ved Neapel, synes i ingensomlelst Henseende at skille sig fra vor nordiske Form, der ntvivlsomt er identisk med Fabricius's Art. Det samme er ogsaa Tilfældet med $N$. Herlstii Leach og N. Montagui Thomp-

\section{Nebalia bipes (Fabr).}

(I'l. I, figs. 1-3: PI. II and III; P]. IV, figs. I-8; Pl. V.).

Cancer bijes, O. Fabrieins, Fauna Grönlandica n. 223.

Cancer gamarellus bipes, Herbst, Geschichte der Krabben \&c. II, III.

Nebatia Herbstii, Leach, Zool. miscell. I. p. 100. Milne-Edwards. Hist. nat. des Crustacés, III. p. 356.

Nebalia Montagui, Thompson, Zool. Iesearches.

Nebalia bipes, Froỵer, Grönlands Amplipoder, p. 91.

- - Naturh. Tidsskr. 2 Series, II, p. 436.

- - Gaimard's royage en Scandinavie, Pl. 40, fig. 2, $\mathrm{a}-\mathrm{x}$.

- - Baird, British Entomostraca.

Nebalia Gcoffroyi, Milne-Edwards, Ann. de sc. nat. 1828.

- - M-Edwarls, Hist. nat. d. Crustacés, III. Claus, Zeitschr. f. wissensch. Zoologie, XXII, p. 323 , PI. XXY.

Clans, Untersuchungen zur Erforscliuug der genealogischen Gruudlage res Crustaceen systems, p. 24, Pl. XV, fig. 4-6.

Nebrlin bipes, A. S. I'ackard, A Monograph of the Phyllopod Crustacea of North America, with Reuarks on the order Phyllocarida p. 432, Pl. XXXVIXXXVII

Specific characters. - Body of rather slender form, especially in the male. Carapace of considerable size, viewerl laterally in female oval, in male elliptical in form, about the same height in front as behind. Frontal plate evenly rounded at the extremity, withont terminal spina. Eyes well developed, somewhat compressed, with the outer part somewhat expanded and obliquely rounded, pigment of dark red coloni. Superior antemn in female about the length of the anterior division of the body, with the flagellum about as long as the peduncle and the lamellar appendage oval; in male considerably more prolonged, with the flagellum more than twice as long as the peduncle, and the lamelliform appendage narrow elliptical. Inferior antennæ in female half again as long as the superior ones; in male as long as the entire body, with the flagellum extremely thin and prolonged. Epipodite of the branchial legs very large, elliptic, with the lower lobe of same size as the upper one. First pair of swimming legs dentated along the entire length of the exteroir edge of the onter ramns. Caudal rami in female about as long as the 2 last segments of the posterior division of the body together; in male more than twice the length. Colom varying from light whity-yellow to intense red-brown. Lengtl of the boly reaching $12 \mathrm{~m} . \mathrm{m}$.

Remarks. - The Mediterranean form, N. Geoffroyi, M.Edw. of which I have lad specimens for investigation, collected by my father off Naples, appears in no respect, whatever, to distingnish itself from our northern form, which is, undoubtedly, identical with Fabricins's species. The same is also the case with N. Herlstii Leacb, and N. Montagni Thompson. 
son. Overhovelet synes kun denne ene Art at vaere observeret af andre Forstere. Fra den folgende meget nærstaaende, skjondt sikkert specifiskt forskjellige Form er den strax kjendelig ved de vel udviklede og med tydeligt Pigment og Synselementer forsynede Oine, samt red Pandepladens forskjellige Form.

\section{Beskivelse at Humuen.}

Legemets Læunde, regnet fra Spidsen af Pandepladen til Enden af de sammenlagte Halegrene, er hos de storste af mig observerede Exempiarer, tagne ved Lofoten, omtrent. $12 \mathrm{~mm}$. Exemplarer fra vor Syd- og: Vestkyst er ialmindelighed noget mindre.

Legemets Form (se Tab. I, Fig. 1 og 2) ınaa idethele siges at være temmelig slank, især naar man observerer Dyret i levende Tilstand. Paa de i Spiritus opbevarede Exemplarer synes ialmindelighed Legemet nuget kortere og mere mndersæetsigt paa Grund af en red Spiritusens Action frembragt kjendelig Contraction i Ledfoiningerne mellem de forskjellige Segmenter; noget der ogsaa bemærkes paa de fleste af andre Forskere givne Figurer af dette Dyr. Hele den forreste Halvpart af Legemet lækkes mere eller mindre fuldstandigt af Rygskjoldet, bag hvilket den hagtil sucressivt afsmalnende og meget bevægelige Haie rager frit frem. Den liabituelle Lighed ned en Copepurle (navnlig visse Herpacticider) er umisliendelig og bliver endmere jaafaldende, naar man observerer Nrret i levende Tilstand, idet Bevægelserne foregar jaa en fuldkommen lignende Maade.

Rygskjoldet er meget stærkt sammentryt fra Siderne, saa at dets Brede km lidet overgaar den halve Hoide, og, da ret desuden mellem sine Sidedele fuldstændig indeslutter ikke blot Munddelene, nen ogsaa alle folgende Forkropslemmer (Branchial forderne), har det mere Lighed med en treklappet Skal, saaledes som vi finder det hos visse Phylloporler og Cladocerer. Ogsata i audje Henseender er demne Lighed tydeligt fremtrædende. Saaledes vil man finde, at lette Rygskjold kun par et meget indskrænket Omraade helt fortil og oventil, danner den umiddelbare Kropsvæg (se Tab. II. Fig. 1), medens det furovrigt limn gankie lost dækker Legemet, som dertor frit kan berages indentor samme. Endelig kan de 2 Sidedele, eller Valvler, ligesom lios de oremærnte Branchiopoder, beræges inod hinanden red $\mathrm{Hj}_{j} \mathrm{l}_{\mathrm{j}}$ af en stærk transrersal Adductormuskel (Tab. IJ, Fig. 7, ms), der lige bag Munddelene forlunder de 2 Valvler med himanden. Insertionen af denne Adductormuskel er ogsaa udvendigt meget tydeligt at se $i$ len formeste Del af hver Valvel, mærmere Iorsalsiden, i Form af en vel begrænclset oval Area, hrori henırkes en Ansam-
Altogether, unly this single species appears to have been observed by other investigators. From the following very closely related, althongl certainly specifically different, form, it is immediately distinguishable by the well developed eyes furnislied with distinet pigment and risual elements, and also by the different form of the frontal plate.

\section{Description of the fomale.}

The length of the body measured from the tip of the frontal plate to the extremity of the folded candal rami is, in the largest specinens that I have observed, taken off Lofoten, abont $12 \mathrm{~mm}$. Specimens from the south and west coasts of Norway are generally somewhat smaller.

The form of the body (see Pl. I tig. 1 and 2) must be said to be. on the whole, rather slender. especially when the animal is observed in the liv. ing state. In specimens preserved in alcohol, the body appears, in general, to be somewliat shorter and stonter, owing to an appreciable contraction of the articnlations between the various segments, produced by the influence of the alcohol, a circumstance also noticed in the illnstrations of this animal supplied by most other naturalists. The entire foremost half of the animal is covered more or less completely by the carapace, behind which the gradually backwards-diminishing and rery mobile tail projects freely. The habitual resemblance to a Copepod (especially certain Harpacticids) is unmistakeable and becomes still more conspicuous when we observe the animal in the living state, as the morements occur in an exactly similar manner.

The carapace is very strongly compressed from the sides, so tliat its breadth but little exceeds lialf the height, and, besides, as it completely encloses between its lateral parts not only the oral parts but also all the succeeding appendages of the anterior division of the loody (the branchial legs), it has more of l'esemblance to a bivalve shell, such as we find it in certain Phyllopods and Cladoceres Also in other respects is this resemblance distinctly prominent. IVe may thus observe tlat this carapace forms, only within a very limited space quite in front and above, the immeliate wall of the body (see Pl. II fig. 1), whilst it, otherwise, only quite lousely covers the hody, which can therefore move itself freely within it. Finally, the 2 lateral parts or valres "an, as in the above-mentionel Branchiopods, be moved towards each other with the aid of a powerful transvensal adductor muscie (see Pl. II fig. 7 , ms.) which immediately belind the oral parts connects the 2 valves to each other. The insertion of this adductor muscle may also be very distinctly observed from the exterior, in the foremost part of each ralve next the dorsal side, in the form of 
ling af klare Pletter (hucid spots), svarende til de enkelte Bundter af Adductormuskelen (se Fig. 1 ms). Nogen virkelig Laasrand, saaledes som lios Ostracoderne og enkelte Phylloporler (Estheria, Limnetis), er imidlertid ikke tilstede, idet de 2 Valvler dorsalt gaar umærkeligt over i hinanden med en jevn Krumning. Seet fra Siden (Tab. I, Fig. 1) har Rygskjoldet en noget uregelmæssig oval, eller næsten rhombisk Form, med omtrent samme Hoide fortil som bagtil. Rygkanten er ganske svagt lonet og danner med de skraat afskaarne bagre Kanter en meget stump Vinkel. Fortil udgaar fra Rygskjoldet overst den bevægelige Pandeplade, som i denne Stilling tager sig nd som et tilspidset, noget nedadboiet Pandeborn. Imellem denne og de forreste, noget udbnede Kanter af Rygskjoldet er der et smalt Indsnit, hvorfra Ginene rager frem. De nedre Kanter er i sin forreste Del stærlkt buede, længere bagtil næsten lige, og forbinder sig under en stærk Krumning med de bagre Kianter, hvorved fremkommer til hver Side en afrundet Sidelap, der næsten rækker lige til Enden af Bagkroppens the Segment. Ovenfra seet (Fig. 2) viser Rygskjoldet sig meget smalt og stærkere afsmalnende fortil end bagtil, hvor det har en dyb, i Bunden smalt afrundet median Indbugtning, der skiller de 2 Sidelappe fra linanden. Ved den forreste Encle af Rygskjoldet sees Pandeplarlen, som nu viser en smal tungedannet Form, med Enden jevnt afrundet (se ogsaa Tal. II, Fig. 2). Den er' forbundet med Rygskjoldet ved et tydeligt Led, saa at den ved særegne Muskler lian snart rettes lige fortil, snart indbøies mod Forkanten, i hvilket Tilfælde den ligesom et Laag dækker fortil for Indgangen til Rygskjoldets Hule. Rygskjoldet er ganske glat, uden nogen tydeligt udpræget Scnlptur og uden Borster eller Torner, af temmelig tynd, boielig, chitinos Cunsistens og halst giennemsigtigt, saa at den indenfor liggende Krop tilligemed dens Lemmer kan skimtes igjennem samme.

For noiere at kunne undersage denne silste, er det imidlertid hensigtsmæssigt at fjerne den ene af Rygskjoldets Valvler (se Tab. II, Fig. 1). Det viser sig da. at Legemet $\mathrm{i}$ sin hele Langle er tydeligt segmenteret, og at Segmenterne grupperer sig til vel markerede Kropsafsnit. Ian kan ialt adskille 4 saadanne Afsnit, hvoraf de 2 tilhorer Forkroppen, de 2 vvrige Bagkroppen. Det forreste Afsnit af Forkroppen kan passende benævies Hovedet (Cephalon); da det, foruden Ginene, kun bærer de 2 Par Folere og de egentlige Munddele (Over- og Underlæbe, Kindbakkerne og 2 Par Kjæver). Dets dorsale Parti, der er af betydelig stor're Udstrækning end dets ventrale, er fast forlundet med Rygskjoldet, a well defined ural area, in which are observed a number of lucid spots corresponding to the individual bundles of the adductor-muscle (see fig. 1, ms). A true cardinal margin, such as appears in the Ostracods and some Phyllopods (Estheria, Limnetis), does not, however, exist, as the 2 valves pass dorsally, imperceptilly into each other by an even curvature. Viewed laterally (Pl. I, fig. 1) the carapace lias a somewhat irregular oval or almost rhomboid form, having nearly the same height in front as behind. The dorsal margin is quite gently curved, and forms with the obliquely truncated posterior margins a very ubtuse angle. The mobile frontal plate issues anteriorly from the upper part of the carapace, and in this situation appears as an acuminate, somewhat downwards-bent rostrum. Between it and the foremost somewhat lunging edges of the carapace, there is a narrow incision from which the eyes project. The lower edges are in their foremost portion greatly curved, but further back almost straight, and mite with a strong curve to the posterior edges, whereby is formed on each side a romded lateral loje that alnost extends to the extrem ity of the 4th segment of the posterior division of the body. Viewed from above (fig. "2) the carapace appears very narrow and diminishing more rapidly in front than behind, where occurs a deep median sinus narrowly rounded at the bottom, which separates the 2 lateral lobes from each other. At the foremost extremity of the carapace appears the frontal plate, which now exhibits a narrow linguiform shape with the extremity evenly rounded (see also P1. II fig. 2). It is connected to the carapace by a distinct articulation, so that it can by means of special muscles be directed, now straight forward now bent in towards the anterior margin, in which case it, like a lid, covers in front the entrance to the eavity of the carapace. The carapace is perfectly smooth, without any distinctly marked sculpture, and is deroid of bristles or spines; of rather thin, flexible, chitinous consistency and semi-transparent, so that the enclosed body with its appendages may be observed through it

In order to elosely investigate the last-named, it becomes desirable to remore the one of the valves of the carapace (see Pl. II fig. 1); it then appears, that the body throughout its entire length is distinctly segmented, and that the segments group themselves into well defined sections of the body. We are able to distinguish in all 4 such sections. of which 2 pertain to the anterior division, and the other 2 to the posterior division of the body. The front section of the anterior division of the body may be suitably termed the head (cephalon), as it, besicles the eyes, only bears the 2 pairs of antennx and the oral parts proper (anterior and posterior lips, the mandibles and 2 pairs of maxillæ). Its 
som her danner den umiddelbare Kropsvæg. Det folgende Afsnit, der forestiller hrad man ialmindelighed pleier at kalde "Truncus» eller "Thorax", men som maaske mere passende bor kaldes Midtkxoppen (mesosome), bestaar af 8 , i sin hele Omkreds tydeligt sondrede, og ensformigt ndviklede Segmenter, der hvert bærer et Par Branchialfodder. Omvendt livad Tilfældet el med Hovedet, har dette Afsnit sin storste Udstrækning ventralt, idet begge Afsnit forbinder sig med hinanden langs en meget skraat gaaende Linie. Maalt langs Dorsalsiden er det her ombandlede Afsuit derfor neppe læengere end Hovedet, medens det ventralt er masten dobbelt saa langt. Bagtil forbinder det sig med Bagkroppen, uden at være afsat fia samme ved nogen mærkbar Indknibning. Det forreste Afsnit af Bagkroppen ("Præabdomen", metasome) el sammensat af 4 Segmenter, alle betydelig storre end de til Truncus horende Segmenter, og hvert forsynet med et Par kraftigt udriklede Srommefodder. Det sidste af disse Segmenter har tydelige pladeformige Epimerer, der ender bagtil med et retrinklet Hjorne. Hele Bagkantell af dette Segment er* desuden regelmæssigt sagtakket, og ogsaa paa det foregaaende Segment bemærkes i den dorsale Del en lignende, skiondt mindre udpræget Beræbning af Bagkanten. Afsnittet, der successirt afsmalnes bagtil, dreklies til Siderne næsten fuldstændigt af Rygskjoldet, medens dets dorsale Del træeler mere eller mindre frit frem indenfor den dybe Indbugtning i Rygskjoldets bagre Del (se Tab. I, Fig. 2): Angaaende Lrengden af dette Afsnit, saa er den noget forskjellig hos de 2 Kjon. Hos Hunnen er det, ialfald maalt langs Ventralsiden, neppe længere end Truncus, medens det selv bos endnn ikke fuldt udvililede Hanner (se Tab. II, Fig. 1) altid er betydelig storre, i Orerensstemmelse med den kraftigere Udvikling af Srommefodderne. Det ydre, meget bevægelige Afsnit af Bagkioppen ( Postabdomen", urosome), der gaar i Flugt med det forreste ${ }^{1}$ ) og jærnt og hurtigt afsmalnes bagtil (se Tab. I, Fig. $10 \mathrm{~g} 2)$, bestaar ligeledes af $\&$ Segmenter, hvoraf de 2 forreste er forsynede med rudimentære Buglemmer, medens de 2 bagerste ganske mangler saadanne. Det er af trind Form, mæsten dobbelt saa langt som det forreste Afsnit $o g$ har Bagkanten af de 3 forreste Segmenter regelmassigt sagtakket, ligesom paa de bagre Segmenter af hint. Til Enden af sidste Segment er Halegrenene indleddede; de symes at svare til den saakaldte Furca hos Copepoderne og tor saaledes nærmest rære at betragte som et i 2 Dele kluvet Endesegment. Under Basis af Halegrenene gaar sidste Segment ad i 2, ved et smalt mediant Indsnit dorsal portion, which is of considerably greater extent than the ventral one, is firmly connected to the carapace, which here forms the immediate wall of the body. The succeeding section, which represents what is usually termed the "trumcus" or "thorax», but which might perbaps be more properly termed the middle section of the body (mesosome) consists of 8 uniformly developed segments, distinctly separated throughout their entire circumference, each of which carries a pair of branchial legs. This section, contrary to what is the case with the head, has its greatest extent ventrally, as both sections are connected to each otler along a very oblique line of mion. Measured along the dorsal side, the section referred to here is, therefore scarcely any longer than the bead, while the ventral part is almost twice as long. Posteriorly it comnects to the posterior division of the borly without being demarcated from it by any noteworthy constriction. The front section of the posterior' division of the hody ("præabdomen", metasome) is composed of 4 segments, all considerably larger than the segments pertaining to the truncus, and each furnished with a pair of powerfully developed swimming legs. The last of those segments has distinct lamelliform epimeræ that terminate behind in a right-angled corner. The entire posterior margin of this segment is, further, regularly serrated, and also in the preceding segment there is observed, on the dorsal part, a similar although not so distinct armature of the posterior margin. 'The section, which diminishes gradually backwards, is almost completely covered at the sides by the carapace, while the dorsal part appears more or less uncovered inside the deep sinus in the posterior part of the carapace (see Pl. I fig. 2). Regarding the length of this section, it is somewhat different in the 2 sexes. In the female it is, at any rate when measured along the ventral side, scarcely longer than the truncus, while it, in even not yet fully developed males (see Pl. II fig. 1), is always considerably larger, in correspondence with the more powerful development of the swimming legs. The outer, very mobile section of the posterior division of the body ("postabdomen", urosome) which forms the immediate continnation of the anterior one ${ }^{1}$ ) and diminishes evenly and rapidly backwards (see Pl. I figs. 1 and 2) consists also of 2 segments, of which the 2 foremost ones are furnished with rudimentary ventral appendages, while the 2 hindmost ones are quite devoid of such appendages. It is cylindrical in form, almost twice as long as the foremost section, and has the posterior cdge of the 3 foremost segments regularly
Hos S1. Paranebalia er lette $\Lambda$ fsnit skaryt afsat fia Preabdomen.
In the gen. Paranclatia this section is sharply clefined from the lrieabdomen. 
skilte, tilspidsede Plader, der delvis dæklser Analaabningen nedentil (se Tal. III, Fig. 12).

Oinene (Tab. II, Fig. 1 og 7 , 0, Fig. 3 og 4), der er frestede temmelig nær sammen ved den forreste Ende af Hovedet, lige nnder Pandepladens Basis, er vel uiviklede og omtrent af Pandepladens halve Længde. De er tydeligt stilkede og meget frit bevægelige, saa at de suart kan rettes ud til hver Side, snart lægges tret ind mod hinanden og boies nedarl, i hvilket Tilfælde de ganske skjules mellem den forreste Del af Rygskjoldets Valvler. Af Form er de noget sammentrykte, aflangt ovale, eller næsteu halvmaanedannede, med den ydre Del noget udvidet og skjævt afrundet, endende nedentil i et vinkelformigt Hjorne. Forkanten af Oiet er ganske glat, uden Spor af de stærlie Sagtakker, som findes her hos Sl. T'aranebalia. Diepigmentet, der hos det levende Dyr er af en vakker pmpurrod Farve, fylder næsten ganske den ydre Halvpart af Øiet, og fra det udstraaler til alle Kanter talrige Synselementer, i Form af smaa stærlit lysbrydende Legemer (Krystalkegler) af kort pæredannet Form. Derimod mangler den Oiet omgivende Hud (Cornea) ganske ethvert Spor af nogen egentlig Facettering som hos de hoiere Crustaceer. Hvert Oie dækkes verl Roden af en fra Pandedelen udspringende skjælformig, i en skarp Spids ndgaaende Plade, der næsten rækker til Mirlten af Oiets Længde (se Fig. 3, 4).

De ovre Folere (Tab. II, Fig. 1, a $^{1}$, Fin. 5), der udspringer lige under Oinene, er af kraftig, næsten fodformig Bygning og, lige nistrakte, omtrent af af Forkroppens Langde. Man kan paa dem adskille et tykkere, dobbelt vinkelboiet Skaft og 2 terminale Vedhæng af ulige Form, hvoraf det ene har Udseendet af en skjælformig Plade, det andet af en forlænget, mangeleddet Svobe. Skaftet bestaar af 4 Segmenter, hvoraf de 2 yderste er fast forbunche iner hinanden, medens det foregaaende (2det) Ler har en meget bevægelig Articnlation saavel med 1ste som 3die Led. 1ste Led af Skaftet er, som det synes meget fast forbundet med Hovedet og kun lidet hevægeligt, hvorfor det ved Dissection vanskeligt kan erholdes i Forbinclelse med den ovrige Del. Det er (se Fig. 1, Fig. 7 a a $^{1}$ af oval Form, nden enhver Borstevæloning og opfyldt med stærlie Mnskel- serrated, as in the posterior segments of the former. The candal rami are articulated to the extremity of the last segment; they appear to correspond to the so-called furca of the Copepods, and may, therefore, be most properly considered to be a bifnreated terminal segment. Below the base of the caudal rami the last segment projects into 2 , by a narrow median incision, separated acuminate lamellæ which partly cover the anal aperture beneath (see Pl. III fig. 12).

The eyes (Pl. II, fig. 1 and 7,0 , figs. 3 and 4 ), which are secured pretty closely together at the foremost extremity of the head, just below the base of the frontal plate, are well developed and abont balf the length of the frontal plate. They are distinctly stalked and very freely mobile, so that they may be directed, now to each side now laid close in to each other and bent downwards, in which case they become quite concealed between the foremost part of the valves of the carapace. In form they are somewhat compressed, oblongooval, or almost semi-lnnar, with the outer part somewliat expanded and obliquely rounderl, terminating below in an angnlar corner. The anterior edge of the eye is perfectly smooth without trace of the powerful sawteeth found in the gen. Paranebalia. The ocular pigment, which, in the living animal, has a beantiful purple-red colour, occupies almost completely the outer half of the eye, and from it radiate numerous visnal elements in all directions, in the form of small, strongly refractive bodies (crystal cones) of short pyriform shape. On the other hand the enclosing integument (cornea) of the eye is quite deficient in every trace of any real facets such as exist in the higher. Crustaceans. Each eye is covered at the base hy a squamiform plate that issnes from the frontal part, and terminates in a sharp point which reaches nearly to the midlle of the length of the eye (see figs. 3, 4).

The superior antemme (Pl.II, fig. $1 \mathrm{a}^{1}$, fig. 5), which issue just under the eyes, are of powerful, almost pediform structure, and when straightly extended are abont same length as the anterior division of the body. We can in them distinguish a thickish doubly geniculated peduncle and 2 temninal appendages of dissimilar form, of which the one has the appearance of a squamiform plate, the other of a prolonger multi-articulate flagellum. The pedmole consists of 4 segments, of which the two outermost ones are firmly attached to each other, while the preceding joint (2nd) has a very flexible articnlation both with the 1st and 3rd joints. The 1st joint of the peduncle is, apparently, very firmly connecter to the head and but little flexible, hence it can with difficulty be obtained on dissection, in nnion with the remaining part. It is oval in form (see fig. 1 , 
knipper, der tjener til at beræge den orrige frie Del af Foleren. 2det Led, der ialmindelighed er rettet lige fortil. damende med 1ste en mere eller mindre tydeligt udpræget albuformig Boining, ex omtrent saa langt som de 2 folgende tilsammen og noget forstykket paa Vidten, næsten tendamnet. Det bærer i Midten af den ovre Kant en enkelt stærk Fjærborste og i den nedre Kant, nærmere Enden, en Rad af omkring 8 saadanne, der hurtigt aftager i Længde udad; ved Spidsen af Leddet findes desuden et Knippe af divergerende simple Børster. Jdie Led, der scedvanlig med det foregaaende danner en meget stærk, r'etvink]et knæformig Boining, er' noget indknebet ved Basis, men udvides successivt mod Enden, der er skjævt afskaaret i Retningen forfra bagtil. Det har i hver Kant, uær Enden, en Rad at cilierede Borster, hvoraf de i Bagkanten el længst. trle Led er meget kort og bredt, næsten triangulært ug ligesom for'egaaende skjævt at'skaaret i Enden, men i modsat Retning, hrorved dets Bagkant bliver meget kort. Forkanten er bevæbnet med en Rad af korte Tormer og ender med et noget sammentrykt, kort triangulært Fremspring, der ved Spidsen bærer en noget stor'e $\operatorname{Torn}^{1}{ }^{1}$. Af de 2 terminale Vedhæng har det forreste Formen af en oval Plade, omtrent af samme Længde som Skaftets Bdie Led, og langs Yderkanten og Spidsen tæt besat med fine haarformige Bor'ster ordnede $i$ to Rader. Det bagre Vedhang, der repræsenterer den egentlige Srobe. er omtrent af Skaftets Liengle og afsmalnes successirt mod Enden. Den bestaar af omtrent 15 Led, hvoraf dog de 3 forste ikke er tydeligt sondrede fra hinanden. Hvert Led bærer verl Enden i Forkanten et Kunppe af smaa Borster, hroraf nogle har Characteren af Sandseredhæng (Lugtepapiller), og i Bagkanten en enkelt simpel Borste. Hos den endnu ikke slægtsmodent udriklede Han (Fig. 1) ligner lisse Folere temmelig samme hos Hunnen, alene med den Forskjel, at Sroben er mere opsvulmet ved Basis og delt $\mathrm{i}$ et noget storre Antal Led.

De nedre Folere (Fig. 1, a $2^{2}$, Fig. (6), som udspringer tæt bag de ovre, mangler ganslie det bladformige Vedheng, men er forovrigt byggede efter samme Type som hine og har ligeledes Skaftet dobbelt genicnleret. 1ste Led er, som paa de orre, meget fast formudet med Hovedet, stærkt musculost fig. $\left.7, a^{1}\right)$, withont trace of any setaceous armature, and filled with strong muscular bundles, which serve to move the remaining free part of the antenna. The 2nd joint - which is usually directed straight formard, forming with the 1st a more or less distinctly marked elbow-shaped bend - is abont as long as the 2 succeeding ones together and somewhat tumefied at the middle, almost fusiform. It carries in the middle of the upper edge a single strong; plunose bristle, and on the lower edge, nearer the extremity, a series of about $\&$ similar bristles that rapidly diminish in length outwards: at the tip of the joint there is, further, observed a bundle of divergent simple bristles. The $3 \mathrm{rd}$ joint, which with the preceding one usually forms a very strong right-angled geniculate bend, is somewhat constricted at the base but gradually expands towards the extremity, which is obliquely truncated in a direction from before backwards. It has on each edge, near the extremity, a series of ciliated bristles. of which those on the pasterior edge are the longest. The 4th joint is very short and broad, almost triangular, and like the preceding one obliquely truncated at the extremity but in the opposite direction, cansing its posterior edge to be very short. The anterior edge is armed with a series of short spines and termin. mates in a somewhat compressed short triangular prominence, which at the point carries a somewhat largish spine ${ }^{1}$ ) Of the two terminal appendages: the furemost one has the form of an oval lamella, about the same length as the 3rd joint of the pedmele, and along the outer edge and at the point it is closely beset with delicate capilliform bristles arranged in two series. The posterior appentage, which represents the flagellum proper, is about same length as the peduncle and tapers gradually towards the extremity. It consists of about 15 joints, of which. however, the 3 fir'st ones are not distinctly separated from each other. Warh joint carries at the extremity, on the anterior margin, a bundle of small bristles, of which some have the nature of sensory appendages (olfactory papillæ), and on the posterior edge a single simple bristle. In the still incompletely sexually developed male (tig. 1) these antennæ resemble pretty much those of the female, with the sole difference, that the flagellum is more tumefied at the base and divided into a somewhat larger number of joints.

The inferior antemæ (tig. $1 \mathrm{a}^{2}$, fig. 6) which issue close behind the superior ones, are completely without the foliaceous appendage, but are constructed, otherwise, according to the same type as those, and have also the pedunele doubly geniculated. The 1st joint is, as in the superior ones very firmly mited to
1) Hos sl. Parrinebalia er lette Fremspring betyolelig storre ug grort sagtakket i Forkanten.
In the gren. Parcucbalia, this prominence is considerably larger aud coarsely serrated on the anterior exlge. 
og uden enhrer Borsteberabning. 2det Led, der omtrent er af samme Storrelse som 1ste, mangler ligeledes Borster. men gaar fortil ud i et kort tandformigt Fremspring. Den ydre Del af Skaftet danner ogsaa her en stærk kuæformig Boining med foregaaende Led, men bestaar kun af et enkelt Led, paa hvilket dog en oprindelig Tvedeling er antydet ved en sharpt markeret Afsats baade fortil og bagtil ${ }^{1}$ ). Til den bagre Afsats er fæstet en stærk Fjærbor'ste, og langs Forkanten af Leddet findes en hel Del saadanne Borster, tildels af betydelig Langde. navnlig red Enden, luror de delris er krandsformigt stillede omkring Leddet. Desuden findes langs den ovre Halvpart af Forlianten en Rad af Smatomer, der nedad successivt tiltager i Jæengde, og en Del lignende Torner bemærkes ogsaa ved Enden af Leddet fortil mellem Borsterne. Svoben er betydelig (næsten dobbelt) længere end paa de ovre Folere og bestaar af omkring 20 borstebesatte Led, livoraf dog de 3 eller 4 inderste er mindre tydeligt begræandsede. Hos den enchu ikke slrgtsmodent udviklede Han skiller clisse Folere (Fig. 1, $a^{2}$ ) sig ræsentlig kun derved, at Sroben er meget tat ringet, eller delt i et stort Antal, endnu ufuldstændigt begrændsede Led.

Orerlæben (Fig. 7, L, Fig. 8), der til Siderne ganske dækies af de nedre Foleres Basalled, danner et tydeligt convext Fremspring af afrundet Form og med den bagre Kant svagt indbugtet $\mathrm{i}$ Midten samt her besat med fine Haar.

Underlæben (Fig. 7, 1, Fig. 9) er meget liden og ranskelig at isolere. Den har imidlertid forekomnet mig at frembycle det Fig. y fremstillede Udseende af en i Midten dylut indskaaret og delvis cilieret Plade.

Kindbakkel'ue (Fig. 1, M, Fig. 10) hav et forholdsvis meget lidet Colpus, hvis ydre Del er baadformig og ender opad $i$ en Spids, hromed det articulerer til Rygskjoldets indre Flade. Dets indre Hule er fyldt med de starke, i Midten ved en chitinagtig Sene forbundne Adductormuskler (se Fig. 10), og fra den bagre Kant udgaal en tynd Chitinsene, lrortil Kindbakkernes Rotationsmuskler fæster sig. Den nasten under en ret Vinkel med det ovrige Corpus indboiede Tyggedel el (se Fig. 11) i Enden lelt i 2 Grene, hroraf den ydre har Formen af en liden triangulær Lamelle, der svarer til det tandede Parti (cutting edge) hos andre Crustaceer, medens the head, strongly musculous, and without any arnature of bristles. The ?nd joint, which is about the same size as the 1 st one, is also quite deficient in bristles, but passes, in front, into a short dentiform projection. The outer part of the peduncle also forms here a strongly geniculated hend with the preceding joint, but consists of only a single joint, upon which, lowever, there is an indication of an original subdivision in the shape of a sharply defined ledge both in front and behind ${ }^{1}$ ). Attached to the posterior ledge there is a powerful plumose bristle, and along the anterior edge of the joint quite a number of such bristles may be observer, partly of considerable length, especially at the extremity, where they are partly arranged in a rerticillate manner around the joint. Further, there may he observed along the upper lialf of the anterior edge a series of small spines, which gradually increase in lengtl below; and a number of similiar spines are also observed at the extremity of the joint in front, between the bristles. The flagellum is considerably longer (nearly double) than on the superior antennæ, and consists of about $2(1$ joints heset with bristles, of which, however. the $301^{\prime} 4$ innermost ones are less distinctly defined. In the not yet sexually fully developed male these antennæ distinguish themselves chiefly (fig. $\left.1, a^{2}\right)$, only by the circumstance that the Hagellum is very closely annulated, or divided into a large number of still imperfectly defined joints.

The anterior lip (fig. $i \mathrm{~L}$, fig. 8) which, at the sides, is quite covered by the basal joints of the inferior antennæ, forms a distinctly convex prominence of rounded form, with the posterior margin faintly hollowed in the middle and beset here witl delicate hairs.

The posterior lip (fig. 7 l, fig. 9) is very small and difficult to isolate. It appears, however, to me, to present the appearance of a partly ciliate lamella, deeply incised in the middle, as shown in fig. ?.

The mandibles (fig. 1, M, fig. 10) liave, relatively, a very small corpus, whose onter portion is navicular in form and terminates abore in a point, by which it articulates with the inner surface of the carapace. Its inner eavity is occupied by the powerful addnctor muscles, which are connected in the middle by a chitinous tendon (see fig. 10), and from the posterior malgin a thin chitinous tendon issues, to which the rotatory muscles of the mandibles are attached. The inasticatory part, which is bent inwards almost at a right angle to the remaining corpus (see fig 11), is divided at the extremity into 2 rami, of which the outer has the form of a

1) Hos sl. Nébaliopsis bestaar denue Imel af 2 tydeligt begrandsede Lerl."

In the gen. Tobaliopsis this part annsits of 2 distinetly refined joints. 
den indre og betydelig storre Gren svarer til Molarprocessen. Den forste er ganske simpel og har kun strax indenfor Spidsen et yderst lidet tandformigt Fremspring. Den sidste er af cylindrisk Form, lidt buet, og har som sædvanlig Enden fint riflet samt mere trært afkuttet paa hoire end paa venstre Kindbakke. Palpen (Fig. 1, 7, Mp, Fig. 10), der ndgaar fra Corpus noget fortil paa det Sted, hvor Tyggedelen forbinder sig med den ydre, baadformige Del, er af særdeles betydelig Storrelse, næsten 3 Gange saa lang som selve Corpus, og viser en Bygning idethele overensstemmende med samme hos hoiere Crustaceer, navnlig Amplipoderne. Den bestaar af 3 skarpt begrændsede Segmenter eller Led, alle ontrent af ens Storrelse, eller knn ganske lidt tiltagende i Længde ndad. 1ste Led er simpelt cylindriskt, dog noget fortykket i lrver Ende, og mangler ganske Borster. Det forbinder sig med 2det Led paa en ganske egen Maade, saa at hegge med hinanden danner et Slags Knæ. 2det Led er i sit basale Parti noget opsrulmet og danner umiddelbart indenfor Ledfoiningen med 1ste, en albnformig Udvidning. Det afsmalnes successivt nod Enden og har i Midten af Yderkanten 3-5 tynde Borster. Sidste Led, der er meget bevægeligt forbundet med ¿det, er temmelig smalt, stærkt sammentrykt fra Siderne og ganske lidt brerlere $\mathrm{i}$ sit ydre Parti, som er jevnt tilrundet i Enden. Det barer langs den nedadvendte skarpe Kant en tæt Rad af fint cilierede, toleddede Børster og har desuden ved Spidsen nok en Rad af meget fine og stærkt krummede Borster. Leddets ovre Kant mangler Borster, men viser $\mathrm{i}$ sit bagre Parti en særdeles fin Ciliering. I sin normale Situs convergerer de to Palper stærkt ved Basis (se Fig. 10), saa at 2det Led paa begge kommer til at ligge tæt sammen i Juxtaposition, indenfor Basalleddene af cle 2 Par Følere. Sidste Led paa hver divergerer igjen noget og træder frit frem enten foran eller mellem Folerues Rod (se Fig. 1, . 1 p).

1ste Par Kjæver (Tab. II, Fig. 1 \& $7 . \mathrm{m}^{1}$, Tab. III, Fig. 1) er af afrundet Form og gaar indad ud $i$ to korte, stumpt afrundede Tyggelappe, livoraf den ydre er storst, næsten af oxedannet Form og, foruden med nogle tildels cilierede Borster, bevæbnet i sit bagre Parti med en Gruppe af smaa, i Enden tvedelte Torner (Fig. 1 a). Den indre Tyggelap er forholdsvis liden, af membranıs Beskaffenhed og paa len næsten træert aflnuttede Ende forsynet med en tæt Rad af særdeles fine cilierecle Borster, foruden en Del korte Torner. Fra Enden af disse Kjæver small triangular lamella, which corresponds to the denticular portion (cutting edge) in other Crustaceans; while the inner, considerably larger ramus corresponds to the molar expansion. The first-named is quite simple, and has, immediately inside the point, only an extremely small dentiform prominence. The last-named is cylindrical in form, slightly curved, and, as nsual, has the extremity finely fluted and more obtusely truncated on the right than on the left mandible. The palp, (fig. 1, 7, Mp. fig. 10), which issnes from the corpus a little in advance of the place where the masticatory part is connected to the onter navicular part, is of partienlarly large size, almost 3 times as long as the corpus itself, and exhibits a structure corresponding, upon the whole, with that of the higher Crustaceans, especially the Amphipods. It consists of 3 sharply defined segments or joints, all of about the same size, or only quite slightly increasing in length outwards. The 1st joint is simple cylindric in form but somewhat tumefied at each extremity, and is quite deroid of bristles. It is connected to the 2nd joint in quite a pecnliar manner, so that they form with each otler a kind of knee. The ?nd joint is somewhat tumefied in its basal part, and forms immediately inside the articulation to the 1st joint an elbow-shaped expansion. It diminishes gradnally towards the extremity, and has $1-5$ slender bristles on the middle of the outer margin. The terminal joint, which is very flexibly counected to the and one, is pretty narrow, strongly compressed from the sides and quite slightly broader in its onter part, which is evenly rounded at the extremity. It bears along the downward bent sharp margin a close series of delicate donble-jointed bristles, and has, further, at the point, yet another series of very delicate and strongly bent bristles. The upper margin of the joint las no bristles, but exhibits a particularly delicate ciliation in its posterior part. In its normal situs the 2 palpi converge strongly at the base (see fig. 10), so that the 2nd joint of each lies in close juxtaposition insile the basal joints of the 2 pairs of antennæ. The terminal joint of each diverges again a little, and appears freely forward either in front of or between the bases of the antennæ (see fig. 1, Mp).

The 1st pair of maxillæ (Pl. II, figs 1 and 7 . $\mathrm{m}^{1}$; Pl. III, fig. 1 ) are rounded in form and pass over, inwards, into two short, obtusely rounded masticatory lobes, of which the outer one is the largest, almost securiform; and armed, besides with some partly ciliate bristles, also, in its posterior part, with a group of minnte spines bifurcated at the extremity (fig. 1 a). The inner masticatory lobe is relatively small, of membranous nature, and furnished on the almost obtusely truncated extremity with a close series of delicate ciliate bristles besides 
udgaar et besynderligt, stærkt forlænget Vedhæng (Tab. III, Fig. 1, p), som ifolge sit Udspring aabenbart repræsenterer en eiendommeligt modificeret Palpe. Den bestaar af en noget tykkere, med en Del tynde Inskelbundter fyldt Basaldel, og en tynd Endesnært, som dog begge gaar ganske umærkeligt over i linanden. Basaldelen, der paa 2 forskjellige Steder har et Bundt af tynde divergerende Borster, viser strax ved sit Udspring en abrupt dobbelt vinkelformig Bøining udad og bagtil, hvorfor den tynde, næsten borsteformige Encledel bliver rettet skrat bagtil og opad langs Siderne af Truncus, rækkende med sin Spids lige op til demnes dorsale Flade (se Tal. II, Fig. 1, $\mathrm{m}^{\mathbf{1}}$ ). Langs den ene Kant af denne Endedel er med korte Mellemrum fæstet circa 16 lange og tynde, ncilierede Borster og til Spidsen 3 lignende; alle Borster viser i Enden en eiendommelig, næsten korketrækkerformig Krumning $o g$ er temmelig stive, samt vende ialmindelighed nedarl og indar. Angaaende dette eiendommelige Vedhængs Function, er der ingen Tvivl on, at det tjener til at rense Rygskjoldets Hule, og dermed ogsaa de tandre Branchialfodder, for fremmede i den indtrængende Dele, i Lighed med hvad Tilfældet er' med det bagre Fodpar lios visse Ostracoder (Cypridinider, Cyprider).

2det Par Kjæver (Tab. U, Fig. 1 og $7, \mathrm{~m}^{2}$, Tab. III, Fig. 2) er udpraget pladeformige og af temmelig compliceret Bygning, mest mindende om samme hos de hoiere Crustaceer (Podophthalmia). Man kan paa dem adskille en af 2 utydeligt begrændsede Segmenter bestaaende Basaldel og 2 fra deme fortil ndgaaende Grene. Basaldelen har indad 4 borstebesatte Lappe, der utvivlsomt svarer til Tyggelappene paa 1ste Par, med den Forskjel, at hver Tyggelap lier altsaa er dobbelt eller delt $i$ to. Den forreste af disse 4 Lappe er imidlertid meget liden, knudeformig og bærer 6 lange, cilierede Borster. De 3 ovrige Lappe er ligeledes borstebesatte paa den tvært afkuttede Ende; men Børsterne er her meget kortere og tættere samt delvis ordnede i flere Rækker. Den midterste af disse 3 egentlige Tyggelappe er betydelig smalere end de 2 ovrige, som omtrent indbyrdes er at ens Storrelse. Af de 2 Endegrene er den indre (p), der forestiller Endognathen eller Palpen, af betydelig Storrelse, noget afsmalnende mod Enden og delt i 2 vel begrændsede Led, hvoraf det 1ste er storst. Begge Led er i Inderkanten besatte med talrige cilierede Borster, delvis ordnede i 2 Rækker, og en af de fra Spidsen udgaaende udmærker sig ved betydelig Længde. Den ydre Gren (ex), eller Exognathen, er betychelig mindre end den indre og rækker neppe udover dennes 1ste Led. Den har Formen af en meget smal elliptisk Plade, ler langs hele Inderkanten og Spidsen er forsynet a number of short spines. From the extremity of these maxillæ a strange, greatly prolonged appendage issues (Pl. III fig. 1, p.) which judged by its origin evidently represents a peculiarly modified palp. It consists of a somewhat thickish basal part occupied by a nnmber of thin bundles of muscles, and a slender terminal lash which, lowever, pass imperceptibly the one into the other. The basal part, which in two different places has a bundle of slender divergent bristles, exhibits, immediately at its origin, an abrupt double-kneed bend outwards and backwards, which causes the thin, almost setiform terminal part to become directed obliquely backwards, and upwards along the sides of the truncus reaching, with its point, quite up to its dorsal surface (see Pl. II, fig. $1 \mathrm{~m}^{1}$ ). Along the one margin of this terminal part there are secured at short intervals, about 16 long, slender, non-ciliate bristles, and 3 of the same kind at the tip: all the bristles exhibit at the extremity a peculiar, almost corkscrew-shaped bend and are rather stiff, and generally turn downwards and inwards Resrarding the function of this peculiar appendage, there is no donbt that it serves to clean the cavity of the carapace, and at same time the delicate branchial legs of foreign, to it penetrating, substances, like what is the case with the posterior pair of legs in certain Ostracods (Cypridinids, Cyprids).

The 2nd pair of maxilla (Pl. II, fig. 1 and $\overline{7}, m^{2}$; Pl. III fig. 2) are of distinguished lamelliform shape, and of rather complex structure, reminding one most of the same maxillæ in the ligher crustaceans ( $\mathrm{Po}$ dopthalmia). We can in them distinguish a - of 2 indistinetly defined segments constrneted - basal part, and two branches issuing from it in front. The basal part has, inwards, 4 lobes beset with bristles which indubitably correspond to the masticatory lobes of the 1st pair, with this difference, that each masticatory lobe is here donble or bifurcated. The foremost of these 4 lobes is, however; very snall, nodiform, and carries 6 long ciliated bristles. The 3 remaining lobes are also beset with bristles on the obtusely truncated extremity; but the bristles are here much shorter and closer and, also, partly arranged in several series. The mesial one of those 3 masticatory lobes proper is considerably narrower than the 2 others, which are mutnally of about the same size. Of the 2 terminal branches, the inner one ( $p$ ) which represents, the endognath or the palp, is of considerable size, diminishing somewhat towards the extremity, and divided into 2 well definerl joints, of which the 1 st one is the largest, Both joints are on the inner margin beset with numerous ciliated bristles, partly arranged in 2 series, and one of them issuing from the point distinguishes itself by its great length. The outer branch (ex), or the exognath, is considerably smaller 
med en regelmæssig Rad af temmelig lange, fint cilierede Randborster.

De 8 Par Branchialfodder, som umiddelbart

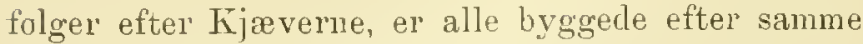
Type og ligger tæt ind mod hinanden i Form af trærstillede Plader, noget mere convexe fortil end bagtil (se Tab. II, Fig. 1). De tiltager noget i Storrelse indtil tde Par og aftager saa igjen successivt bagtil. Paa dem alle kan man (se Tab. III, Fig. 3 -6) adskille 3 fra en frolles Basis udgaaende Hoveddele, som vi, i Lighed med hvad man pleier hos andre Krebsdyr, kan benævne: Endopodit (p), Exopodit (ex) og Epipodit(ep). Den frelles Basaldel bestaar, som paa 2det Par Kjæver, af 2 nfuldkomment sondrede Segmenter, der i Inderkanten har en dobbelt Rad af Borster, Lvoraf de paa iste Segment delvis udmærker sig ved betydelig Længde. Endopoditen (p), der danner den middelbare Fortsattelse af Basaldelen, danner en mod Enden successivt afsmalnende Stamme, paa hvilken der er en srag Antydning til Segmentering. Denne Del er hos den agbærende Hun betydelig strokere forlænget end hos yngre Individer af begge $h_{j}$ jon og har sidste Led vel sondret, noget omboiet og besat med særdeles lange divergerende Fjorborster, der delvis rager frem nedenfor Rygskjoldets Valvler (se Tab. I, Fig. 1). Forovigt er Endopoditen langs hele Inderkanten besat ined Borster, der fordetmeste er ordnede $\mathrm{i}$ en dobbelt Rad og umiddelhart fortsætter de paa Basaldelen forekommende Borsterækker. Exopoditen (ex), del er frestet til Basaldelens zdet Segment, udenom Endopoditen, har Characteren af en bred, langs Midten med en noget fortykket Ribbe forsynet Plade, noget forskjellig i Form paa de forskjellige Branchialfodkler. Paa 1ste Par (Tal). III, Fig. 3) er den legelmæssig oval og i Iderkanten besat med en Ral af circa 18 tynde Borster, tiltagende i Lrengde mod Spidsen. Paa de folgende Par (Fig. 4, 5) bliver den successivt noget storre og starkere udvidet i Enden, som er skjæevt afrundet og lium besat med faa ug sprelte Randborster. Paa sidste Par endelig (Fig. 6) har den antaget en temmelig smal elliptisli Form. Epipoditen (ep), der ved en kort Stilk er fastet til Ydersiden af Basaldelens 1ste Segment, er at særdeles betyclelig Storrelse, saa at den mere eller mindre fuilstrendigt dækker de ovrige Dele, naar disse Lemmer sees in situ fra Tilersiden (se Tab. II, Fig. 1). Den lar Formen af en elliptisli eller næsten halvmaanedannet Plade og gaar ud $i$ en dorsal og en ventral Lap, adskilte $i$ Midten ved en tvars over Ej,ijuditen fra dennes Fæste lobende fortykket Rilub. Ligesom Tilfældet var med Exopoditen, er der ogsaa nogen Forskjel i Epipoditens Storrelse og Form par de forskjellige than the innel one and scarcely extends beyond its 1st joint. It has the form of a very narrow elliptical lamella which, along the entire inner margin and at the point, is furnished with a regular series of pretty long finely ciliated marginal bristles.

The 8 pairs of branchial legs which immediately succeed the maxillix, are all constructed on the same type, and lie close in to each other in the form of transversally placed lamellæ, rather more convex in front than behind (see Pl. II, fig. I). They increase somewhat in size as far as to the 4 th pair and then gradually diminish backwards. In all of them 3 chief portions issuing from a common base (see Pl. III, figs.3-6) may be distinguished, which we, like what we are accustomed to do with other crustaceans, may term endopodite (p), exopolite (ex) and epipodite (ep). The common basal part cousists, as in the 2nd pair of maxilla, of 2 imperfectly separated segments which have a double series of bristles on the inner margin, of which those on the first segment are distingmished by their great length. The endopodite (p) which forms the immediate contimuation of the basal part forms a. trunk, diminishing gradually towards the extremity, mon which there is a faint indication of a segmentation. This part is. in the ovigerous female, considerably more prolonged them in young individuals of buth sexes, and has the terminal joint well separated, somewhat reenrvate and lueset with particularly long divergent and plumose bristles, which partly project below the valves of the carapace (see Pl. I, fig. 1). The endopodite is, otherwise, beset with bristles along the entire inner margin, which are chiefly arranged in a double series, and are immediate continuations of the bristle series appearing on the basal part. The exopodite (ex), which is attached to the ond segment of the basal part, outside the endopodite, has the character of a broad lamella, furnished along the midrle with a somewhat thickened rib, and is a little different in form in the varions branchial legs. In the 1st pair (PI. III, fig. 3) it is regularly oval and beset on the onter edge with a series of about 18 slender bristles inereasing in length towards the point. In the succeeding pairs (figs. 4.5 ) it becomes gradually somewhat larger and more strongly expanded at the point, which is unevenly rounded and beset with ouly few and seattered marginal bristles. Finally, in the last pair (fig. (6) it has assmmed a pretty narrow elliptical form. The epipodite (ep), which is attached by a short stem to the outer side of the 1st segment of the basal part. is of particnlarly large size, so that it more or less completely covers the remaining parts when those appendages are viewed in situ from the outer side (see Pl. II, fig. 1). It has the form of an elliptical, or almost semilunar plate, and passes ont into a dorsal and a ventral lobe divided in the middle by a thickened rib which 
Par Branchialfødder. Dens Storrelse tiltager noget indtil tde Par, hror den er storst, og aftager saa igjen successivt paa de bagenfor liggende Par (se Tab. II, Fig. 1). Paa 1ste Par (Tab. III, Fig. 3) er dens ventrale Lap betylelig storre end den dorsale og smalt tillobende i Enden, medens hin er jevnt afrundet. Paa de folgende Par (Fig. 4, 5) bliver Forskjellen mellem de 2 Lappe efterhvert mindre, og paa sidste Par (Fig. 6) er Forholdet det omvenite af hvad det er paa 1ste Par, idet den dorsale Lap her er den storste og mere smalt udlobende end den ventrale. Saavel Exopoditen som Epipoditen, men især denne sidste, viser den for Gjelleelementerme hos andre Krebsdyr characteristiske spongiose Structur, idet der mellem de 2 Lameller, lıvoraf begge disse Vedhæng begrændses, findes et compliceret System af med hinanden anastomoserende $\mathrm{Hul}$ rum, hrori der hos ret levende Dyr foregaar en livlig Blodcirculation. At begge disse Vedhæng derfor er af respiratorisk Betydning, er ganske utvivlsomt, skjondt, som senere skal vises, ogsaa selve Rygslijoldet spiller $\mathrm{i}$ deme Henseende en vigtig Rolle.

De 4 forreste Par Bagkropslemmer (se Tab. II, Fig. 1) er overordentlig kraftigt udviklede Svømmeapparater, der i flere Henseender, og ogsaa i den Maade, hvorpaa de bevæges, minder on Copepodernes Srommefodder. De er alle byggede efter samme Type og bestaar hvert (se Tab. III, Fig. 7 og 9) af en med talrige stærke Muskelbuncter fyldt, noget affladet Basaldel, og to fra dennes Ende udgaaende, med cilierede Svommeborster for'synede, enleddede Grene eller Aarer, hvoraf den ydre ialmindelighed er rettet stærkt udad og i Yderkanten bevæbnet med kraftige Torner. Paa alle Par findes ved Enden af Basaldelen paa den indre Side en eiendommelig indadrettet Fortsats (Fig. 8), der moder den tilsvarende paa den anden Side $o g$ i Spidsen er bevæbnet med et Antal, sædvanlig 4, krogformige Torner (Fig. 8 a). Ved disse Torner hægtes de 2 til samme Par horende Fodder ligesom sammen, saa at deres Bevægelser kun kan ske samtidigt.

1ste Par Svømmefodder (Fig. 7) skiller sig lijendeligt fra de ovrige, saavel ved Basaldelens Form og Beræbning som ved Beskaffenherlen af den ydre Gren. Basaldelen, der ligesom paa de ovrige Par har et ganske kort Rodled, er her forholdsvis længere og smalere, noget aftagende i Brede mod Enden, og bevabnet med 4 lange Torner, hroraf en er crosses the epipodite from its point of attachment. As was the case with the exopodite, there is also some difference in the size and form of the epipodite in the varions pairs of branchial feet. The size increases somewhat until the 4th pair, where it is greatest, and it then diminishes again, snceessively, in the prairs sitnated behind (see Pl. II, fig. 1). In the 1st pair. (Pl. III, fig. 3) the ventral lobe is considerably greater than the dorsal one, and projects in a narow pointed form at the extremity, while the latter is evenly rounded. In the sncceeding pairs (figs. 4,5 ) the difference between the two lobes becomes gradually less, and in the last pair (fig. 6) the relation is the reverse of what it was in the 1st pair; as the dorsal lobe is here the largest one and more narrowly projecting than the ventral one. Both the exopodite and the epipodite, but especially the last-named, exhibit the characteristic spongy structure for the gill-elements in other crustacea; as between the 2 lamelli by which the appendages of both are limited, there is found a complicated system of cavities, anastomosing with each other, in which, in the living animal, an active bloorl circulation mroceeds. That both these appendages are therefore of respiratory importance is perfectly indubitable, although, as will be subsequently shown, the carapace itself also plays an important part in that respect.

The 4 foremost pairs of the posterior appendages of the body (see Pl. II, fig. 1) are extremely powerfully developed swimming legs which, in several respects as well as in the manner in which they are moved, remind us of the swimming feet of the Copepods. They are all constructed on the same type, and consist, each (see Pl. III, figs. 7 and ("), of a somewhat flattened basal part filled with numerous strong bundles of muscles, and two branches or oars, issuing from its extremity and fumished with ciliated swimming-bristles. Of these branches the onter one is usually directed strongly outwards, and is armed on the onter elge with powerful spines. In all the pairs there is found, at the extremity of the basal part on the imner side, a peculiar projection directed inwards (fig. 8), which meets the corresponding one of the other side, and is armerl at the point with a number - nsnally 4 - uncinate spines (fig. 8 a). The 2 feet pertaining to the same pair are, as it were, hoolied together by these spines, so that their movements can only take place simultaneonsly.

The 1st pair of swimming feet (fig. 7 ) are perceptibly distinguished from the others, both by the form and armature of the basal part as well as by the nature of the onter branch. The basal part which, as upon the other pairs, has a quite short basal joint, is here relatively longer and narrower, somewhat narrowing in breadth towards the extre- 
fæstet helt oppe ved Basis til Yderkanten. en anden helt nede red det ydre Hjorne, medens de 2 ovrige ndgaar fra den mederste Del af Inderkanten. Den ydre Gren er temmelig smal, men successivt noget iredere mod Enden, og har langs Yderkanten en regelmæssig Rad af circa 20 korte Torner, hvorpaa folger, fæstet til en særegen Afsats, en betydelig stærkere saadan. Fra den noget skraat afkuttede Ende udgaar 3 stærke divergerende Torner, hvoraf den yderste er læugst, den midterste kortest. Hele den indre Kant af Grenen er forovrigt besat med en tret Rad af lange og tyucle cilierede Borster. Den indre Gren er betydelig længere og ogsaa smalere end den ydre, næsten lineær, og viser ved Basis et ufuldstrndigt sondret lidet Rodled. Den er $\mathrm{i}$ begge Kanter forsynet med en Rad af lignende Srommeborster som paa den ydre Gren og gaar ved Enden ud i en kort dolkformig Spids, indenfor hvillien en lang bagudrettet Torn er frestet.

Paa de ovrige Srommefodder (Fig. 9) er Basaldelen kortere og bredere, mere affladet, og har Yderkanten tilskjærpet sant endende nedad med et spidst udtrukket Hjorne. Inderkanten er ligesom Yderkanten nden Toner, men har 2 Ḱnipper af meget fine Borster, skilte red et længere Mellemrum. Mellem de 2 Grene danner Basaldelen et lancetformigt tilspidset Fremspring. Den ydre Gren er forholds. vis storre og bredere end paa 1 ste $\mathrm{Par}$ og har langs Iderkanten 7 Afsatser, hver bevæbnet med 2 tæt sammenstillede divergerende Torner; fra Spidsen ndgaar, som paa 1ste Par, 3 'Torner, som her successirt tiltager i Længde inclad. Den indre Gren er knn lidet længere end den yrlre, men betydelig smalere, forovrigt af samme Beskaffenhed som paa 1ste Par. Det bagerste Par skiller sig neppe fra de ? foregaaende nden derved, at det er noget mindre.

De 2 Par rndimentære Bagkropslemmer, der er frostede til Bugsiden ved Enden af כte og 6te Segment (se Tab. I, Fig. 1), er begge af meget enkel Bygning og som det synes ganske ubevægelige. 1ste Par (Tab. III, Fig. 10) er det storste og bestaar hvert af 2 Segmenter, et kort Basalled og et mere langstrakt, i sin ydre Del lidt udvidet Endeled. Dette sidste er langs Inderkanten besat med fine Barster og har langs den skraat afskaarne Enderand en Rad af 7 Torner, hvoraf den yderste er længst: mellem Tornerne bemærkes ogsaa en Del fine lige udad rettede Borster. - 2ilet Par (Fig. 11) er neppe mele end halvt saa lange som 1ste og bestaar hrert af et enlielt ovalt Led, hvis Inderkant er ret. medens Yderkianten er noget buet. Til den mity, and armed with 4 long spines, of which one is secured to the outer edge, quite up at the base; another quite down at the outer corner, wlillst the 2 others issue from the lowest part of the inner. edge. The outer branch is pretty narrow, but is somewhat more successively broad torards the extremity, and has a regular series of about 20 short spines along the onter edge, succeeded by a considerably more powerful one secured to a special projection. From the somewhat obliquely truncated extremity there issue, 3 strongly divergent spines, of which the ontermost one is the longest, and the medial one shortest. The entire inner erlge of the branch is otherwise beset with a close series of long and slender ciliated bristles. The inner branch is considerably longer and also narrower than the onter one, almost linear, and exhibits at the base an imperfectly separated, small hasal joint. It is furnished on both edges with a series of similar swimming bristles as on the outer branch, and at its extremity passes into a short lanceolate point, inside of which a long spine. directed backwarts, is secured.

On the other swimming feet (fig. 9) the basal part is shorter and broader, more flattened, and has the onter elge sharpened and terminating downwards in an acntely drawn ont corner. The inner edge, like the onter one, is devoid of spines, but lias two bundles of very fine bristles, separated by a longish interval. Between the two branclies the basal part forms a lanceolate pointed projection. 'The onter branch is relatively larger and broader than in the 1st pair, and has 7 projections along the onter edge, each of which is armed with 2 divergent spines placed closely to each other; from the point there issue, as in the 1st pair, 3 spines, which increase liere successively in length inwards. The inner branch is only a little longer than the outer one, but considerably narrower; otherwise of the same character as in the 1st pair. The last pair are scarcely distinguished from the 2 preceding ones, muless in that they are somewhat smaller.

The 2 pairs of rndimentary, posterior appendages of the body, which are secured to the ventral side at the extremity of the 5th and 6th segments (see Pl. I, fig. 1), are both of very simple structure, and, as it appears, quite immobile. The 1st pair ( $\mathrm{Pl}$. III, fig. 10) are the largest, and each consists of 2 segments, a short basal joint and a more elongated, in its outer part slightly widened, terminal joint. This last is beset along the inner edge with fine spines, and along the obliqnely truncated terminal margin has a series of 7 spines, of which the ontermost one is the longest; between the spines there are observed, also, a number of fine bristles directed straight ontwards. The 2nd pair (fig. 11) are scarcely more than half as long as the 1st, and each consist of a 
sidste er fæstet 4 stærke Tormer, og fra Spidsen udgaar 2 lignende, hvoraf den inderste er længst. Inellem Tornerne findes ogsaa her fine ndadrettede Borster, medens Børsterne i Inderkanten er stærkt reducerede.

Halegrenene (Fig. 12) er omtrent saa lange som de 2 silste Bagkropssegmenter tilsammen og ialnindelighed stærkt divergerende. De er af smal lineær Form, ganske lidt afsmalnende nod Enden og rundtom forsynede med en Rad af korte ncilierede Torner, der ved Spidsen antager Formen af stærkt forlængede Borster. Fornden disse findea langs Inderkanten en Rad af betyclelig læugere og finere, tæt cilierede Borster.

Dyrets Farve er noget varierende fra meget bleg gulagtig til temmelig intens rodbrun. De mest udpreget farvede Exemplarer har jeg observeret i vor arktiske Region.

\section{Beskrivelse af dell sliegtsmodne Han.}

Medens den endun ikke slægtsmorlne, skjondt forovrigt fuldt ndvoxede Han (se Tab. II, Fig. 1) kun lidet skiller sig i sit Udseende fra Humen, er Forskjellen mellem de to Kjon i den slægtsmodne Tilstand saa skarpt udpræget (se Tab. I, Fig. $1 \mathrm{og}$ 3), at man uclen en noiere Undersogelse knapt engang skulde tro, at de tilborte samme Art. Kjonsforskjellen er ndtrykt saavel i den hele Habitus som i Structuren af enkelte af Lemmerne, især de 2 Par Folere, der er modificerede paa en meget lignende Marde som hos Hannerne af de fleste Amphipoder.

De storste Hanner, jeg har fundet, havde en Længde af omtrent $12 \mathrm{~mm}$; men jeg har ved vor Sydkyst truffet Hanner af knapt mere end den halve Storrelse, skjondt fuldstæncligt slægtsmodent udviklede.

Legemets Form er (se Tab. I, Fig. 3) paafaldende smækrere eud hos Humen, og navnlig er Rygskjoldet kjendelig smalere, seet fra Siden af elliptisk Form, med Hoiden neppe halvt saa stor som Længlen. Fremdeles er Bagkroppen noget læugere i Forhold til Forkroppen, og dens forreste Afsnit kraftigere ndviklet end hos Hunnen. Endelig giver de enormt forlængede Halegrene Dyret et fra Hum nen meget afvigende Udseende.

Dinene er fuldkommen af samme Bygning soin hos Humnen, men synes noget storre og har det ydre Parti stærkere ndvidet. single oval joint whose inner edge is straight, whilst the outer edge is somewhat curved. To the last named 4 strong spines are secured, and 2 similar ones issue from the point, of which the innermost one is the longest. Between the spines there are also found here fine bristles directed outwards, whilst the bristles on the inner nargin are greatly reduced.

The caudal rami (fig. 12) are about same length as the two last posterior segments of the body taken together, and are usually strongly divergent. They are of narrow, linear form, quite slightly narrowed towards the extremity, and furnished roundabout with a series of short non-ciliated spines, which at the tip assume the form of greatly prolonged bristles. Besides these there are found, along the immer edge, a series of consiclerably longer and finer, closely ciliated bristles.

The colour of the animal is somewhat variable. from very pale yellowish to pretty intense redhrown. I have observed the most distinguished colonred specimens in the Norwegian Arctic region.

\section{Description of the sexually ripe luale.}

Whilst the not yet sexually ripe male, although in other respects fully developerl (see $\mathrm{Pl}$. II, fig. 1), distinguishes itself in appearance only slightly from the female, the difference between, the two sexes in the sexually ripe condition is so sharply defined (see Pl. I, fig. 1 and 3), that without a close examination the observer would scarcely even believe that they pertained to the same species. The sexual difference is expressed both by the entire habitus, as well as in the structure of some of the appendages, especially the two pairs of antennæ, which are modified in a very similar manner to that of the males of most Amphipods.

The largest males I have found had a length of abont $12 \mathrm{~mm}$; but on our south coast I have met with males of scarcely more than half the size, although completely sexually developed.

The form of the body (see Pl. I, fig. 3) is conspicnously more slender than in the female, and the carapace, especially, is perceptibly narrower; riewed from the side the shape is elliptical, the height being scarcely half so great as the length. Further, the posterior division of the body is somemhat longer in relation to the anterior one, and its foremost section more powerfully dereloped than in the female. Finally, the enormonsly prolonged candal rami impart to the animal a very different appearance from the female.

The eyes are of exactly the same structure as in the female, lut appear to be somewhat larger, and hare the outer portion more dilated. 
De ovre Folere (Tab. IV, Fig. 1) er betydelig længere end hos Hunnen og, lige udstrakte, omtrent saa lange som Forkroppen og "Præabdomen" tilsammen. Skaftet skiller sig ikke væsentligt $i \sin B y g-$ ning fra samme hos Humnen, lrorimod begge de ter. minale Vedhæng er kjendelig forskjellige. Det bladformige Vedhæng el' forholdsvis betyrlelig storre og mere forlænget, omtrent 4 Gange saa langt som bredt, eller paa det nærmeste af samme Længde som de to sidste Led af Skaftet tilsammen. Forovrigt viser det den samme characteristiske tætte, kostformige Børstebesætning som hos Hunnen. Sivoben er særdeles stærkt forlænget, mere end dobbelt saa lang som Skaftet og stærkt afsmalnende mod Enden. Den er sammensat af 17 vel begrændsede Led, Lvoraf det 1ste egentlig repræsenterer 3 med hinanden sammensmeltede Led. De 1 - i0 forste Led er stærkt opsvulmede $i$ sit ydre Parti og her besatte med en tæt Kiranús af yderst fine gjennemsigtige Sandseborster. De ydre Led bliver efterhaanden overordentlig tynde og forlangede; dog er sidste Led noget, kurtere end de nmiddelbart foregaaende.

De nedre Folere (se Tab. I, Fig. 3) er af hele Legeméts Længde, Halegrenené iberegnede, og udmærker sig især ved den overordentlig tynde og forlrongede, af talrige korte Led bestaaende Srobe, der. ialmindelighed er lige bagud rettet. Derimod skiller Skaftet sig (se Tab. IV, Fig. 2) kun lidet fra samme hos Humnen. Dog er dets sidste Led noget tykkere og mangler de lange Fjærborster, der hos Hunnen ndgaar fra Enden, i hris Sted der blot findes nogle meget fine Haar.

Kindbakkeme og Overlæben viser fuldkommen samme Udseende som hos Hunnen.

Ogsaa de 2 Par Kijerer (Fig. 3 og 4) er byggede paa samme Maade som hos Hunnen; men begge Par er forholdsvis mindre og har navnlig Tyggelappene meget svagere udviklede samt kun for'synede med yderst smaa, simple Borster.

Branchialfodderne (Fig. 5) har den egentlige Stamme, eller Endopoditen, betydelig svagere uclviklet end hos Hunnen og neppe overragende Exopoditen. Ogsaa er de paa den fastede Borster kortere og alle af ens Udseende, uden at de i Spidsen tæstede ndmærker sig ver en paafaldende Læugde. I Modsætning hertil er saavel Exopoditen som Epipoditen særdeles store og deres Gjellestructur endnu mere ndpræget end hos Humnen.

Bagkroppens Svommefodder er idethele liraftigere udviklede end hos Humen (se Tah. I, Fig. 3),
The superior antennæ (Pl. IV, fig. 1) are considerably longer than in the female, and when straightly extended are abont as long as the anterior division of the body and the præabdomen taken together. The peduncle does not particularly distinguish itself in structure from that of the female while, on the other hand, both the terminal appendages are perceptihly different. The lamelliform appendage is, relatively, considerably larger and more prolonged, about 4 times as long as it is broad, or nearly of the same length as the two last joints of the peduncle together. It exhibits otherwise the same characteristic, close, brush-like, bristly armature as in the female. The flagellum is particnlarly greatly prolonged, more than twice as long as the peduncle, and is greatly narrowed towards the extremity. It is composed of 17 well-definerl joints, of which the first one really represents 3 , which are coalescent with each other. The 9-10 first joints are greatly thickened in their outer portion, and are here covered with a close wreath of estremely fine, transparent sensory bristles. The onter joints become gradually extraordinarily slender and prolonged; but the last joint is somewhat shorter than the immediately preceding ones.

The inferior antemnæ (see Pl. I, fig. 3) are as long as the entire body, the candal rami included, and are especially distinguished by the extraordinarily slender and prolonged flagellum, consisting of numerous short joints, which is usually directed straight backwards. On the other hand the peduncle (see Pl. IV, fig. 2) distinguishes itself ouly little from the same part in the female. Still its last joint is somewhat thicker, and is without the long plumose bristles which, in the female, issue from the extremity; in place of them there are only found a few very fine hairs.

The mandibles and upper lip exhibit exactly the same appearance as in the female.

The 2 pairs of maxillæ also (fig. 3 and 4) are constructed in the same manner as in the female; but both pairs are relatively smaller, and have, especially, the masticatory lobes much more faintly developed and only furnished with extremely small simple bristles.

The branchial feet (fig. 5) have the stem-proper, or endopodite, considerably fainter developed than in the female, and scarcely reaching beyond the exopodite. The bristles attached to it are also shorter and all alike in appearance, without those attached to the point distingnishing themselves by any remarkable length. In contrast herewith the exopodite as well as the epipodite are particnlarly large, and their gill-strncture more distinguished than in the female.

The swimming feet of the posterior division of the body are altogether more powerfully developed 
men skiller sig forovigt ikke syuderligt i sin Bygning.

De 2 Par rudimentære Bagkropslemmer (Fig. 6 og 7) er ligeledes noget storre end bos Humnen, og sidste Par (Fig. T) har her et tydeligt afsat lidet Rodled, ligesom 1ste Par. I sin Form og Bevæbning stemmer iovrigt begge Par temmelig noie overens med samme hos Hunnen.

Halegrenene ndmærker sig (se Tab. I, Fig. 3) verl en $\mathrm{i}$ Forhold til samme hos Hunnen meget paafaldende Lrongde, idet de endog er saa lange som de 5 bagiu Pañanmsanmenter tilsammen, eller næsten af Legemets halve Lrengde. 1: or (Tab. IV, Fig. 8), som hos Hunnen i hver hant bevæune..e ned en Parl af korte 'Torner, hvoraf dog de i Yderkanten her er meget talrigere og finere end de i Inderkanten. Desuden findes, som hos Humnen, langs ken indre Kant en Rad af temmelig lange og tynde Ejarborster.

Farven el' $\mathrm{i}$ levencle Tilstand gjennemgaaende blegere end hos Humnen og Legemet halvt gjennemsigtigt.

\section{Indre Organer}

Undersogelsen af den indre Organisation er los nærværende Dyreform forbunden med ganske særlige Vanskeligheder. Dyret er ialmindelighed iklie g.jennemsigtigt nok til at at man kan mmiddelbart studere deme paa det levende Dyr: og ved Dissection af opbevarede Exemplarer kommer mun iklie meget langt, paa Grund af det complicerede System uf Muskler, som ongiver og tildels fylder den i og for sig meget trange Irropshule. Hertil kommer endnu et meget stærkt udviklet, og med talrige Fedtkugler fyldt Binderær, som omsprender de forskjellige Organer $\mathrm{og}^{\circ} \mathrm{kun}$ vanskeligt lader sig skille fi'a samme. Heller ikke Snitmethoden har givet mig fuldt ud tilfredsstillende Resultater. Bedst har jeg kumnet faa undersogt den indre Bygning i sin Helhed ved af et stort Antal Exemplarer at udvalge enkelte ualmindelig gjennemsigtige og helst ganske unge Individer og nndersoge disse directe under Mikroskopet i levende Tilstand. Ved at combinere disse Under'sogelser'med hrad jeg har kunnet fremstille red Dissection, har jeg endelig efter meget Besvær troet at faa nogenlunde Rede paa den indre Organisation hos denne mærkelige Dyreform. Forst efterat disse Undersøgelser forlængst var afsluttede, erholdt jeg Prof. Claus's fortjenstfulde Arlueide: "Untersuchungen zur Erforschung der genealogisehen Grundlage des Crustaceen-System*, hvori den indre Organisation hos Nebalia i Korthed omtales, med Vedføielse af strerkt forstorrede Figurer af Han og Hun, fremstillede som transparente Objecter. De than in the female (see Pl. I, fig. 3), but do not otherwise distinguish themselves particularly in their structure.

The 2 pairs of rudimentary, posterior appendages of the body (figs. 6 and 7 ) are likewise somewhat larger than in the female, and the last pair (fig. 7) have here a distinctly defined, small basal joint like the 1st pair. In their shape and armature both pairs correspond otherwise pretty exactly with the same organs in the female.

The candal rami distingnish themselves (see $\mathrm{Pl}$. I, fig. 3) by a very striking length.in relation to the length of the same in the female, as they are even as long as the 5 backmost segments of the posterior body taken together, or nearly half the length of the body. They are ( Pl. IV, fig. S), as in the female, armed on each edge with a series of short spines, of which, however, those on the onter edge are here mnch more numerous and finer than those of the inner edge. Thrre are found, besides, as in the female, along the inn'r edge, a series of pretty long and thin plumose setæ.

'The colour, in the live state, is, pervadingly, paler than in the female, and the lindy is semitransparent.

\section{Internal organs}

The investigations of the internal urganization is in the present animal. form attended with quite special difficulties. The animal is generally inste ${ }^{2}$ iciently transparent to enable us to study it directiy in the living state; and on dissection of preserved specimens we make no rreat progress on acconnt of the complicated muscular system which surrounds and partly fills the, in itself very narrom, body cavity. To that is added still, a very strongly developed, and with fatty globules filled, connectiretissue, which encloses the varions organs, and permits itself with difficulty to be separated from them. Neither has the sectional method afforded me completely satisfactory resnlts. I have been enabled to investigate the internal structure in its entirety best, by choosing from among a large number of specimens some more than usually transparent, and preferably quite young, individuals, and by investigating these in the live state directly nnder the microscope. By combining these investigations with what I have been able to present by dissection, I have finally after much difficulty, I believe, been able to obtain in some measure an elucidation of the internal organization of this remarkable animal form. First after these investigations liad long previonsly been concluder, did I obtain Prof. Claus's admirable work «Untersuchungen zur Erforschung der* genealogischen Grundlage des Crustaceen System» in which the internal organization of Nebalia is shortly mentioned, and illustrated by greatly mag- 
Resultater, hvortil jeg er kommet, stemmer irlethele temmelig vel overens med hvad Claus her har meddelt. Paa Tab. V fremstiller Fig. 1 en Hun seet fra Siden og stærkt forstorret, merl de forskjellige Organer indtegnede i samme og anlagte med forskjellige Farver. Fig. 2 fremstiller et Trærsnit af Legemet omtrent over Midten af Trunens; de indre Organer er anlagte med samme Farve som paa Hovedfignren.

\section{Tarmtractus.}

Spiserøret er meget kort og stiger fra Mundaabningen lodret i Veiret, forbindende sig under en næsten ret Vinkel med den forreste, i Hovedet liggende Del af Tarmen. Dette forreste Afsnit af Tarmtractus er forsynet med et temmelig compliceret Chitinskelet (Tah. V, Fig. 3, t) og danner saaledes et Slags Tyggemave, noget lignende den bos Amphipoderne for kommende. Paa Chitinskelettet kan adskilles 3 iforeddele, en for'este, en midterste og en bagers,ce Del. Den forreste Del er noget affladet $\mathrm{og}$ indeholder 2 fortil divergerende Lister, besatte med en dobbelt Rad af fine, tæt sammentrængte Chitinpigge. Lige ved Indgangen til Spiseroret 'indes desuden ventralt 2 parvise Forhoininger, besatte med indadrettede Borster. Den midterste De! er temmelig stærkt opsvulmet og bagtil skraat afskaaret, dannende her en næsten klokkeformig Jdvidning, hvorfr'a rager frem et Par tæet laarede Flige. Det er her at de til Tarmen horende Leversække forener sig for at ndmunde i Tyggemavens Lumen. Den bagerste Del. endelig, dauner en lang skedeformig, og i de frie Kanter med fine Borster besat tynd Flig. der kun indtager Dorsalsiden af Tarmen og med sin $\mathrm{i}$ en fin Spids udtrukne Ende rækker langt ind i selve Truncus. Tarmen danner' forovrigt et simpelt cylindriskt, med stærke Ringmuskler forsynet Ror, der strækker sig igjennem hele Midtkroppen. Bagkroppen og Mesteparten af Halen. Ved Enden af næstsidste Halesegment forbinder den sig med en kort. stærkt muskulos Endetarm, der aabner sig nedennder Basis af Halegrenene. Af Leversække findes ikke mindre end 4 Par, alle særdeles tynde og saa fast forbundne med Tarmen med fedtholdigt Binderæv, at de yderst vanskeligt lader sig isolere fra samme. Det forreste af disse Par er meget korte og rettede fortil over Tyggemaven, medens de 3 ovrige Par følger Tarmen bagud og ender omtrent ved Begyndelsen af Halen. Paa Tvarsnit (Fig. 2) viser disse sidste (cd, cv) sig grupperede næsten i Form af en Rosette omkring og tret ind mod Tarmen, med et noget storre Mellemrum mellem det dorsale Par. nified figures of male and female, presented as transparent objects. The results at which I have arrived agree, upon the whole, pretty well with what Claus has here stated. Plate $V$, fig. 1 represents a female viewed laterally and greatly magnified, with the various organs drawn in the representation and coloured with different colonrs. Fig. 2 represents a transversal section of the body across nearly the middle of the truncus; the internal organs are colonred with the same colours as in the chief figure.

\section{The intestinal tract.}

The oesophagns is, rery chnnt win rises perpendicnlarlyr from the oral aperture, connecting i'seir at almost a right angle with the foremost part of the intestine situated in the head. That foremost section of the intestinal tract is furnished with a pretty complicated chitinous skeleton (Pl. 4, fig. 3. 4) and forms thus a kind of masticatory stomach, somewhat like what is present in the Amphipods. Three chief parts may be distinguished in the chitinous skeleton, a front one, a medial one, and a back one. The front portion is somewhat flattened and contains 2 fillets which diverge to the front and are beset with a donble series of fine, closely crowded chitinons spikes. Exactly at the mouth of the oesopbagus there are further found, ventrally, 2 prominences in pairs, beset with bristles directed inwards. The medial part is pretty greatly swollen ont and obliquely truncated behind, forming here a nearly bell-shaped dilation, from which a pair of densely hirsute flaps project. It is here that the liver-sacs pertaining to the intestine unite, in order to debouch into the cavity of the masticatory stomach. The posterior part finally forms a long sheatn-like thin flap which is, on its free edges, beset with fine bristles, and only occupies the dorsal side of the intestine; and which, with its extremity drawn ont to a fine point, extends far into the truncus itself. The intestine forms, otherwise, a plain cylindrical tube furnished with strong ring-muscles; which extends itself through the entire mesosome, the metasome, and the greater part of the urosome. At the extremity of the penultimate caudal segment, it connects itself to a short, strongly muscular rectum which opens below the base of the caudal rami. Of liver-sacs there are no less than + pairs found, all of them particnlarly slender, and so firmly connected to the intestine by fatty connective-tissne that it is extremely difficult to isolate them from it. The foremost pair of these saes is very short and directed forwards above the masticatory stomach, while the 3 other pairs follow the intestine backwards and terminate at about the beginning of the urosome. In transversal sections (fig. 2) these last show themselves 
(cd, cv), grouped nearly in the form of a rosette, around and elose in to the intestine, with a somewhat largish interval between the dorsal pair.

\section{Blodkarsystemet.}

Hjertet (Fig. 1, Fig. 2, c) er af langstrakt spindellannet Form og strækker sig, umiddlelbart ovenfor Tarmen, igjemem hele Midtkioppen og Storsteparten af Bagkroppen, endende omtrent red Enden af dennes 3die Segment. I Midtkroppens 5te Segment har det sin storste Vidde og viser her til hver Side en meget ioinefaldende Tværspalte. En lignende, men betydelig mindre Spaltaabning sees til hver Side helt fortil, red Hjertets Begyndelse. Claus har desuden afbildet, mellem begge Par, 4 meget smaa dorsale Spaltaabninger, som det dog ikke er lykkets mig at far se tydeligt. Fra Hjertets forreste Ende udgaar en, ialfald i sit inderste Parti tydelig Arterie, og ogsaa Hjertets bagre Ende har forekommet mig at fortsætte sig $\mathrm{i}$ en lignende bagudlobende Arterie. Noget virkeligt udviklet Blodkarsystem synes dog neppe at være tilstede, og Blodet circulerer, som hos andre lavere Crustaceer, væsentlig liun i vægløse Hulrum mellem Bindeværet og Musklerne. I Branchialfodderne er allerede omtalt Tilstedeværelsen af saadanne med hinanden anastomoserende Blodgange, navnlig i de 2 ydre Vedhæng (Exopodit og Epipodit). Et lignende System af væglose Blodkanaler findes ogsaa mellem Rygskjoldets 2 Lameller, og da Cirkulationen her er meget livlig, har man Grund til at antage, at Rygskjoldet spiller en ikke uvæsentlig Rolle ved Dyrets Respiration.

\section{Nervesystemet.}

At undersoge Nervesystemet i sine Detailler, er forbundet med særdeles store Vanskeligheder, da dets Centraldele ligger saa tæt omgivne af Muskler og Bindevæv, at de yderst vanskeligt lader sig isolere ved Disection. Paa Tværsnit af Kroppen (PI. V, Fig. 2) kan man dog let orientere sig angaaende Buggangliekjædens Beliggenhed $(\mathrm{g})$, og kan herefter bestemme dens Plads ogsaa i Profil af Dyret (se Fig. 1). Hjernegangliet har det kun lykkets mig at se temmelig ufuldstændigt. Det synes ikke at være af nogen betydelig Storrelse, og ndsender, fornden Synsnerverne, stærke Nervestammer til de 2 Par Folere. I Midtkroppen ligger de enkelte Knuder af Buggangliekjæden tæt sammen, kun forbundne med meget korte og tykke Langdecommissurer, mellem hvilke der linapt er noget Mellemrum. Selve Ganglierne er forholdsvis smaa og alle af ens Storrelse, deres 2 Halvdele fuldkommen sammen-
The blood-vessel system.

The heart (fig. 1, fig. 2 c) is of elongate, fusiform shape, and extends, immediately above the intestine, through the entire mesosome and the greater part of the metasome, terminating at about the extremity of the 3rd segment of the latter. It has its greatest hreadth in the 5th segment of the mesosome, and exhibits here on either sirle a very prominent transversal fissure. A similar, but considerably smaller fissure-aperture is seen on each side, quite in front, at the commencement of the heart. Claus has illustrated besides, between both pairs, 4 very small dorsal fissmre-apertures, which I have, however, not been fortmnate enongh to observe distinctly. From the foremost extremity of the heart there issues a, at least in its innermost portion, distinct artery; and also the posterior extremity of the heart has appeared, to me, to continue itself in a similar backward rumning artery. Any real, developed blood-ressel system scarcely appears, however, to be present; and the blood circulates, as in other lower Crustaceans, prineipally, only in cavities, without walls, between the connective-tissue and the muscles. In the branchial feet, the presence of such blood pasages, anastomosing with each other, has already been mentioned; especially in the 2 onter appendages (exopodite and epipodite). A similar system of blood-ducts, without walls, is also found between the 2 lamellæ of the carapace, and as the circulation is here very active there is reason to suppose that the carapace plays a not unimportant part in the respiration of the animal.

\section{The nervous system}

To investigate the nervous system in its details is a matter of particularly great difficulty, as its central portions lie so closely snrrounded by muscles and connective tissue that it is excessively difficult to isolate them by dissection. In transversal sections of the body (Pl. V, fig. 2) we can, however, easily obtain information concerning the situation of the rentral ganglial chain (g), and can from this determine its sitnation also in a side-view of the animal (see fig. 1). I have not been fortnnate enongh to observe the ganglion of the brain very perfectly. It does not ajpear to be of any considerable size, and sends off, besides the optical nerves, powerful nervous stems to the 2 pairs of antemw. In the mesosome, the individual knots of the ventral ganglial chain lie close together, only counected by very short and thick longitudinal commissures, hetween which there is scarcely any interval. The ganglia 
smeltede med hinanden og udsendende 2 stærke Sidestammer, der udbreder sig dels i Branchial. fadderne, dels i Kropjens Muskulatur, De 4 i Bagkloppen beliggende Ganglier er betydelig storre og ogsaa mere fjernede fra hinanden, med længere og mere tydeligt skilte Commissurer. I Halen løber ') Nervestammer langs ad Bugsiden lige til Halegrenene, og danner for hvert Par af de smaa Hale-

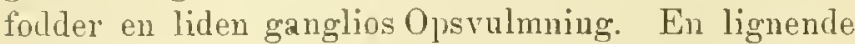
synes ogsaa at findes ved Basis af Halegrenene.

\section{Generationsorganerne.}

Orarierne er til sine Tider meget let at observere hos det levende Dyr, da de med stor Tydelighed skimer igjennem Integumenterne paa Grund af sin intense rodgnle Farve. De danner (se Pl. V, Fig. 1, Fig. 2, ov) 2 langstrakte Sække, der strækker sig, til hver Side af Tarmen, igjemem hele Miltkroppen og Bagkroppen og rager endog et Stykke ind i Halen. I enhver af Srkkene findes kmn en enkelt Række sig ndviklende Egr, alle med tydelig Kimblære og grovkom et Blommemasse. Aggelederne har det iklie lykkets mig at faa se saa tyde ligt, at jeg med Bestemthed lian angive deres Plads. Let har imidlertid forekommet mig, at de udmunder ved Basis af 6te Par Branchialfodder. Testes lar omtrent samm: Beliggenhed som Ovarierne og danner ligesom disse simple Sække, men er betydelig smalere end disse. De munder, ifolge Clans ved Basis af sidste Par Branclialfodder.

\section{Udvikling}

Eggene optages, som ovenfor navnt, efter at være komne ud af Eiglederne, i et Slags Rngehule, der ligger ind under Midtkroplen, ongiven af Rygskjoldets Valvler og delvis begrandset af Branchial fodderne, hris talrige krummede Endeborster hindrer lem fra at falde ud af Rygskjoldets Hule. De undergaar her sin hele Udvikling, og forst naar Ungerne er saa ridt komme, at le med Lethed kan bevæge sig i Vandet, forlader de klækkehulen. Udviklingen er noiere studeret af den russiske Naturforsker Kowalewsky, og mine Undersogelser stemmer i alt vasentligt overens med hvad der af denne udmærlielle Forsker er meddelt. Eggene er umiddelJart efter at være optagne i Klækkehulen, af rodgul Farre og noget oval Form. Senere antager de lidt. efter lidt en noget lysere Conleur og bliver ogsaa n+le giennemsigtige. De er, som hos Flelheden af Crustaceerne, meroblastiske, idet Stersteparten af themselves are relatively small and all alike in size; their 2 halves are completely coalescent with each other, and send off 2 powerful lateral stems which distribute themselves partly in the branchial feet and partly in the muscles of the body. The 4 ganglia situated in the metasome are considerably larger and also situated farther apart from each other, with longer and more distinctly separated commissures. In the urosome 2 nerve-stems pass along on the rentral side, right to the caudal rami, and form, for each pair of the small caudal feet, a small gangliar swelling. A similar swelling a jpears also to be present at the base of the caudal rami.

\section{The reproductive organs.}

The ovaries are at times very easy to observe in the living animal, as they shine through the integuments with great distinctness, owing to their intense red-yellow colour. They form (see Pl. V, tig. 1, fig. 2, ov) 2 elongate sacs which extend themselves to each side of the intestine through the entire mesosome and metasome, and reach even some way into the urosome. In each of the sacs there is found only a single series of developing ova, all having a distinct germinative vesicle and coarsely granular yolk substance. The ovarial ducts I have not been fortunate enough to observe so distinctly that I can with precision state their. situation. It has, however, appeared to me that they debouch at the base of the 6th pair of branchial feet. The testicles lave nearly the same situation as the ovaries and, like these, form plain sacs, but are considerably narrower than them. According to Clans they delonch at the base of the last pair of branchial feet.

\section{Development.}

The ova are received, as above stated, after having been discharged from the ovarial ducts, in a kind of hatching cavity, which is situated in below the mesosome. surronnded by the valves of the carapace and partly limited by the branchial feet whose unmerous bent terminal bristles prevent them from falling out of the cavity of the earapace. They undergo here their entire development, and first when the young ones have advancerl so far that they can move themselves with ease in the water do tley abandon the hatching cavity. The develoument has been closely studied by the Russian naturalist Kowalervsky, and my investigations agree in all naterial points with what has been stated by that eminent investigator. The ova are, immediately after having been received into the hatching cavity, red-yellow in colour, and somewhat oval in shape. Subsequently they, little by little, assume 
Aggets Blommemasse ikke undergaar nogen Klovning. Ifolge Kowalewsky dannes det blastodermale Cellelag ved den successive Klovning af en enkelt stor Polarcelle. Paa et temmelin tidligt Udviklingsstadium, som er fremstillet Pl. V, Fig. 6, finder vi, at Blommemassen $i$ den ene Halvdel af Egget er bægerformigt omgivet af et Lag af klare Celier, der navnlig i Kanten af Egget tydeligt hrevel sig af fra den mere ugjennemsigtige rodgule Blommemasse. Dette er den sig damende Blastoderm. Det forste Anlæg til Embryonet antydes ved en svag transversal Indbugtning $\mathrm{i}$ Blastodemen, begrendset af 2 noget fremspringende Vulster. Den ene af disse Vulster forestiller Overlæben, den anden Haleenden (se Fig. 7 og 8). Til hver Side af den ovenomtalte Indbugtning viser sig noget senere 3 tværstillede langagtige Forhoininger, del' for'estiller Anlægget til de 2 Par Folere og Mandibularpalperne, og foran dem sees til hver Side en ntydeligt begræudset rundagtig Udvidning, der aabenbart er Anlægget til Oienstilkene. Embryonet, der endnu er omgivet af Eggehinden, befinder sig nu i det saakallte Nauplinsstadium. Senere optræeder, bag de 3 Par ovenomtalte Lemmeanlæg, successivt en dobbelt Ræklse af mindre Forhoininger, del antyder Anlægget til de folgende Lemmer (se Fig. 7). Samtidigt bliver den transversale Indbugtning dybere, Haleenden sondrer sig tydeligere og stræber at fjerne sig fra Overlæben, Ivvad der tilsidst, i Eorbindelse med Embryonets Væxt, har tilfolge at Eggehinden brister og skaller af. Det Stadium, som nu folger, er det saakaldte Puppestadium, som el fremstillet Fig. $9 \mathrm{og}$ 10. Embryonet, som nu kun er omgivet af en overordentlig tynd og gjennemsigtig Membran, Larvehuden, viser ikke længere len oprindelige ventrale Krumning, men har strakt sig fuldt ud i Lrengden og endog antaget en svag dorsal Boining. Formen er næsten kolledannet, idet Legemet fortil ligesom er opblæst, paa Grund af en betydelig Rest af Blommemassen, der fylder det lier dorsalt. Man kan saaledes egentlig paa Legemet adskille to temmelig skarpt sondrede Hoveddele, en nasten kngleformigt opsvnlmet forreste Del, og en betylelig smalere, nasten cylindrisk og bagtil i en stump Spids udgaaende Del. Den forste svarer narmest til Hovedet, hos det voxne Dyr, medens den sidste i sig indbefatter baade Midtkrop, Bagkrop og Hale. Saavel paa len forreste som bagerste Del kan der nu adskilles en dobbelt Række af lemmelignende Fremspring, men af et endnu yderst ufuldkomment Udseende, kun dannende simple koniskt tillobende Fortsatser. Storst og tydeligst sondrede er de 2 forreste Par $\left(a^{1}, a^{2}\right)$ som forestiller de 2 Par Folere. De hal en næsten polsedannet Form og el boiede bagud langs Siderne af Forkroppen. Imellem dem i Midten sees et tydeligt klapformigt Fremspring (L), som er Overlæben, og foran dem til hver Side en a somewhat lighter colour and also become more transparent. They are, as in most of the Crustacea, meroblastic, as the greater part of the ovum's yolk does not undergo ally segmentation. According to Kowalewsky, the blastodermatic cellular layer is formed by the successive segmentation of a single large polar cell. In a pretty early stage of development, which is represented in $\mathrm{Pl} .4$, fig. 6 , we find that the yolk in the one lialf of. the ovum is surrounded by a cup-shaped layer of clear cells which, especially on the edge of the ovum, distinguish themselves from the more opaque red-yellow yolk. That is the Blastorlerm in course of formation. The first rudiments of the embryo is indicated by a faint transversal incurvation of the blastoderm, limited by 2 projecting swellings. The one of these swellings represents the upper lip, the other the candal extrenity (see fig. 7 and S). On each side of the above-mentioned in-cnrvature there, somewhat later, appear :3 transversally placed, elongate prominences which represent the rudiments of the 2 pairs of antennæe and tlie palpi of the mandibles; and in front of them there is seen on either side an indistinctly limited, roundish dilatation, which is evidently the rudiment of the ocular peduncles. The embryo, which is still surrounded by the skin of the ovum, finds itself now in the so-called Nauplius stage. Subsequently there appears, behind the rudiments of the 3 pairs of appendages above mentioned, successively, a double series of smaller prominences, which indicate the rudiments of the succeeding appendages (see fig. 7). At the same time the transversal in-curvature becomes reeper, the candal extremity separates itself more distinctly and endeavon's to remove itself from the upper lip, with the eventual effect, in connection with the growth of the embryon, that the skin of the ovum bursts and scales off. The stage which now succeeds is the so-called pupa stage, represented in fig. 9 and 10 . The embryo, which is now only surrounded by an extraordinarily thin and transparent membrane, the larval skin, no longer exhibits the original ventral curvature, but has stretched itself fully out in length, and even assnmed a faint dorsal curvature. The sliape is almost clavate, as the body in front is, as it were, blown out, owing to a considerable remnant of the yolk substance which here occupies it dorsally. We can thus in the body really distinguish two pretty sharply separated chief parts, an almost globularly shaped swollen front part, and a considerably narrower, almost eylindrical, part passing ont in a blunt point behind. The filst named corresponds closest to the liead of the adult animal, while the lastnamed contains within itself the mesosome, the "metasome and the urosome. In the front, as well as in the postelior part, there can now be dis tinguished a double series of limb-like prominences 
temmelig stor rundagtig Forhnining (0), Anlægget til Oienstilkene. Bug Folerne folger 3 Par ligeledes palsedanuede, men hetydelig mindre Vedhæng, hvori man let erkjender Anlægget til Mandibularpalperne (IIp) og de 2 Par Kjaver $\left(\mathrm{m}^{1}, \mathrm{~m}^{2}\right)$. Langs Siderne af den bagre Del af Legemet sees en nafbrndt Rækike af ialt 11 Par simpelt koniske Fortsatser, hvoraf de $s$ forreste er af fuldkommen ens Udseende og staar næsten ret nd til Siderne, medens de 3 bagerste Par er mindre tydeligt fremragende og mere nedadrettede. Alle disse Fortsatser er egentlig kun simple poseformige Udkrængninger af Larrehnden, og forst indenfor dem sees Anlægget til et tilsrarende Antal Lemmer. De forstnærnte 8 Par Fortsatser (brp) synes at svare til et lignende Antal Branchialfodder, medens de 3 bagerste Par (pl) aabenbart antyder ligesaamange Svommefodder. Den bagenfor liggende Del af Puppens Legeme er uden ethrert Spor af Fortsatser og simpelt koniskt tillobende. Indenfor den giennemsigtige Larvehnd, som temmelig lost omgiver den bagre Del af Embryonets Krop, er allerede en tydelig Segmentering hemærkelig, og man kan herved temmelig noie bestemme Grændsen mellem le forskjellige Kropsafsnit. Kun det bagerste Afsnit, Halen er endnu nfuldkomment segmenteret. I den forreste Del af Legemet sees til hver Side, ligeledes indenfor Larrehnden, en utydelig halrcirkelformigt bnet Linie (c), rer forestiller den frie Kant af det sig ndviklende Rygskjold, og helt fortil, umirldelbart ovenover Anlægget til Oienstilkene, er der et lidet knudeformigt Fremspring $(\mathrm{R})$, der aabenbart forestiller den sig undviklende Pandeplade. I Axen af den bagre Del af Legemet har allerede Tarmen anlagt sig i Form af en med et klart lysegult Inhold fyldt simpel Kanal, der dog endnu er Inkket i sin hagre Ende, medens den fortil staar $\mathrm{i}$ aaben Kommunication med den rummelige, af Blommemasse fyldte $\mathrm{Hule}$, der indtager den dorsale Del af Hovedet. Fig. 11 forestiller det umiddelluart efter Puppestadiet folgende Udviklingstrin. Hrad der vasentlig adskiller dette Stadinm fra det foregaaende, er, at Larrehnden nu er afkastet, saa at de forskjellige Kropsredlıng alle er frit fremragende, ligesom Legemets Segmentering ogsaa ndrendigt er tydelig. Den dorsale Krumning af Embryonet er mu saa stærk, at Legemet næsten bestriver en fuldstændig Halvcirkel. De til Hovedet horende Lemmer har voxet adslitligt i Storrelse, men er forøvrigt kun lidet forandrede. Dog bemærkes paa det forreste Par $\left(a^{1}\right)$ en liclen Bigren, som antyder det bladformige Appendix. Branchialfodderne (brip) er tilstede i sit fulde Antal (8 Par) og riser sig alle dybt tveklaftede, samt lige nedadrettede. Derimod findes der endnn kun anlagte 3 Par Srommefodder ( $\mathrm{pl}$ ), idet det 4de Par forst meget senere udvikler sig. Heller ikke sees noget Spor af Halefodder. Halen sely lar imidlertid nu sit fulde Antal which however have, as yet, an extremely imperfect appearance, forming only plain conically shaped prolongations, The 2 foremost pairs $\left(a^{1}, a^{2}\right)$ which represent the 2 pairs of antennæ, are the largest and most distinctly separated. They hare almost a sansage-shape, and are curved backwards along the sides of the anterior body. Between them, in the middle, there is seen a distinet flap-shaped prominence (L.), which is the upper lip, and in front of them, on either side, a pretty large roundish prominence $(0)$, the rndiments of the ocular stems. Behind the antennæ snceeed 3 pairs, likewise sansageshaped, but considerably smaller appendages, in which we easily recognize the rudiments of the mandibnlar palps $(M p)$ and the 2 pairs of maxillæ $\left(\mathrm{m}^{1}\right.$, $\mathrm{m}^{2}$ ). Along the sides of the posterior part of the body there is seen a continnons series of 11 plain, conical projections in all, the 8 foremost ones of which are of exactly the same appearance and stand almost straight out at the sides, while the 3 hackmost pairs are less distinetly projectant and direeted more downwards. All these projections are really only plain bag-shaped bnlgings of the larval-skin, and first to the inside of them is there seen the rudiments of a corresponding number of appendages. The first namerl s pairs of projections (brp) corre. spond, it wonld seem, to a similar number of branchial feet, whilst the 3 backmost pairs (pl) evidently indicate the same number of swimming feet. The portion of the body of the pupa situated behind is without the least trace of projections and runs ont in plain conical form. Inside of the transparent larval skin, which pretty loosely surrounds the posterior portion of the body of the embryot, there is already a distinct segmentation noticeable, and we can by it pretty distinctly determine the demarcation between the varions divisions of the body. The backmost dirision only, the urosome, is as yet imperfectly segmented. In the anterior part of the body there is seen on either side, likewise insirle the larval skin, an indistinct, semicirenlar curved line (c), which represents the tree edge of the carapace in course of development; and quite in front, immediately above the rndiments of the ocnlar stems, there is a small nodular prominence $(R)$ which evidently represents the frontal plate in course of development. In the axis of the posterior part of the body the intestine laas already begun to appear in the form of a plain canal, filled with a clear light yellow substance, which is still closed at its posterior extremity, whilst, in front, it stands in open communication with the roomy cavity filled with yolk substance which occupies the dorsal part of the head. Fig. 11 represents the stage of development immediately succeeding the pupa stage. What chiefly distingnishes this stage from the preceding one is, that the larval skin is now thrown off?, so that the varions 
Segmenter, og Halegrenene er tydeligt afsatte samt hver i Spidsen forsynet med en kort Borste. Pandepladen $(\mathrm{R})$ er nu tydeligt fremragende, og Dienstilkene.(O) har antaget en noget konisk Form samt viser i sin ydre Del den forste svage Antydning til Dannelse af Synselementer. Til hver Sile af Tarmen bemærkes i Midtliroppen en temmelig plump og kort cylindrisk Sæk, der aabenbart forestiller en af Leversækkene. Den dorsale Del af Forkroppen er endnu stærkt opblæst og fyldt af rodgul Blommemasse. Umiddelbar't nedenfor deme Del sees nu tydeligt de frie Kanter af Rygskjoldet. De Forandringer, Embryonet endnu har at gjennemgaa, er ganske successive. Den tilbageværende Rest af Blommemassen opbrnges lidt efter lidt, og samtidigt aftager den dorsale Opsvulning af Hovedet i Storrelse, medens Rygskjoldets Valvler mere og more roxer ud over Siderne af Midtkroppen. De forskjellige Tropsvedhæeng ndformes og indtager den for dem characteristiske Stilling i Forhold til Legemet, hrorved ogsaa meget suart Nebalia-Habitusen bliver fremtrædende. Fig. 12 fremstiller Ungen, naar den el færdig til at forlade Tŕlækkehulen. Man har ingensomhelst Vanskelighed med $\mathrm{i}$ den at erkjende en ung Nebalia. Den eneste ræsentlige Afvigelse er, at der fremdeles kun er 3 Par Srommefodder tilstede. Af det 4de P'ar sees liun et nbetydeligt Anlæg bag de ovrige, i Form af et Par smaa knudeformige Fremspring $\left(p^{1}\right)$. Ungen kan $n$ bevæge sig frit $i$ Vandet og ernære sig selv; men det varer endnn adskillig Tid, inden de forskjellige Vedhæng opnaar sin fulde Udvikling og faar sin normale rigelige Borstebesætning. Af alle Vedhæng er 4de Par Svommefodder de, som udvikler sig senest. appendages of the body are all freely projectant, while, also, the segmentation of the body is distinct externally. The dorsal curvature of the embryo is now so great, that the body almost describes a complete semi-circle. The appendages pertaining to the head have considerably increased in size, but are otherwise only little changed. Still there may be noted on the foremost pair $\left(a^{1}\right)$ a little subbranch that indicates the lamelliform appendage. The branchial feet (brp) are present in their full number ( $\delta$ pairs) and show themselves to be all deeply fissured and directed straight downwards. On the other hand, there are as yet only fonnd 3 pairs of swimming feet $(p l)$ in a rudimentary state, as the 4 th pair only much later becomes developed. Neither is there any trace of caudal feet observed. The urosome itself has now, however, its full number of segments, and the caudal rami are distinctly projected and each furnished with a short bristle at the tip. The frontal plate $(R)$ is now distinctly projectant, and the ocular stems have now assumed a somewhat conical form and in their external part exihibit the first faint indication of the formation of visnal elements. In the mesosome, on each side of the intestine, there is noticed a pretty stout and short cylindrical sac, which evidently represents one of the liver sacs. The dorsal part of the anterior body is still greatly blown out and filled with red-yellow yolk substance. Immediately below that part the free edges of the carapace are now distinctly seen. The changes that the embryon has yet to undergo are quite snceessive. The remains of the volk substance are little by little used up, and the dorsal swelling of the head becomes at same time reduced in size, while the valves of the carapace grow more and more out over the sides of the mesosome. The varions appentages of the body become fully formed and occupy the characterstic position in relation to the body peculiar to them, cansing thus the Nebalia habitus very soon to become prominent. Fig. 12 represents the young one when it is ready to abandon the hatching cavity. We have no difficulty whatever, in recognizing in it a young Nebalia. The only material divergence is, that there are still only 3 pairs of swimming feet present. Of the 4th pair there is only seen a faint rndiment, behind the others, in the shape of a pair of small nodular prominences $\left(\mathrm{p}^{1}\right)$. The young one call now move itself freely in the water, and nourish itself; bot some time still passes, before the various appendages attain their full development and acquire their normal, abundant bristle-covering. Of all the alpendages, the 4th pair of swimming feet are those which develope themselves latest. 


\section{Forekomst or Lerevis.}

Den her omhandlede mærkelige Dyreform forekommer ikke sjelden langs vor hele Kyst, fra Christianiafjorden til Vadso, men synes idethele at optræde baade hyppigst og kraftigst ndviklet $\mathrm{i}$ ror arktiske Region. I stor Mrngde har jeg saaledes fundet den paa en Plads i Lofoten, Brettesnas, hror mange hundrede Individer indsamledes i Lobet af et Par Dage, og ogsaa ved Finmäken har jeg paa siue Steder truffet den i mangdevis. Den pleier at holde til paa maadeligt Dyb, fra 10 til 30 Favne, og helst paa saadame Steder, hvor Bunden er drektet af forraadnende Tangarter, hvoraf den for en væsentlig Del synes at elnære sig. Ligesom Tilfaldet er med flere andre Crustaceer, synes Hannerne kun til visse bestemte Tider af Aaret at opnaa fuld Slagtsmodenled, og optræder da kun ganske enkeltvis. Derimod er enduu iklie slægtsmodent udriklede Hanner at finde til enhver Tid af Aaret og nasten $\mathrm{i}$ samme Antal som Hunmelne. I Maaden at beræge sig paa, ligesom i sin hele ydre Habitus, har dette Dyr en miskjendelig Lighed med en colossal Copepode; narnlig er den labitulle Overeusstemmelse med visse Harpacticicler meget paafaldende. Ligesom hos disse sidste, er Legemet overordentlig boieligt, navnlig i dorsal Retning, og kan ofte krmmmes saa stærkt, at Halegrenene kommer i Contaet med Pandepladen. Bevægelsen sker stodvis ved liraftige og temmelig rythmiske Slag af Svommefodderne, hvorved Legemet drives frem med temmelig betydelig Fart. De slægtsmodne Hanner er overotdentlig raske i sine Berregelser og foretager ofte langere Udflugter i Vandet. Derimod holder Hunnerne og de endnu ikke fuldt udviklede Hanner sig i Regelen ved Bunden og bevæger sig her mellem Bundmaterialet, ialmindelighed paa Siden. De forstaar herunder med stor Behændighed at skjule sig mellem Mudret eller de hensmuldrende Tangrester, som bedækker samme, saa det slet ikke er saa let at fiude dem frem, trods den ikke ubetydelige Storrelse. Lettest opdager man rlem ved at slaa det optagne Bundmateriale ud i et fladt Kar, med en ubetydelig Krantitet af Sjovand. De tilstedeværende Exemplayer vil da, især naar man rorer lidt om i Bundsatsen, snart vise sig paa Overfladen af Vandet, $o g$ da de $i$ Lighed med forskjellige andre Crustaceer ikke formar at homme ned i Vandet igjen, efterat de forst er komne i Berorelse med Luften, kan de med Lethed opsamles i levende Tilstand. Bringer man et helst yngre Individ $\mathrm{i}$ en passende Kvantitet Sjovand under Mikroskopet, kan man saa noiere studere de forskjellige Livsytringer og kan gjennem de halvt gjennemsigtige Integumenter observere Hjertets Pnlsationer, 'Tal' mens perestaltiske Bevægelser og Branchialfoddernes Spil. Disse sidste, ler ingensomhelst Inflydelse har paa Locomotionen, vil man i Regelen finde $i$ en

\section{Distribution and habits.}

The remarkable animal form spoken of here appears not rarely along our entire coast, from the Christianiafiord to Vadso, but seems, on the whole, to appear most frequently, and most powerfully developed in our Arctic region. I have thus found it in great abundance at a place, Brettesnæs in Lofoten, where many hundreds of individuals were collected in the comrse of a comple of days; and also in Finmark I have, in certain places, met with it in great abundance. It is acenstomed to keep itself at a moderate depth, from 10 to 30 fathoms, and preferably in those places where the bottom is eovered with decomposing sea-weed of which it appears, to a material extent, to nomish itself. Like what is the case with several other Crustaceans, the males appear to only attain full power of reproduction at certain fixed seasons of the year, and are then met with only quite solitary. On the other hand, not fully reprodnctively ripe developed males are to be found at all seasons of the year, and almost in equal number to the females. In manner of movement, as well as in entire external habitus this animal has an unmistakable likeness to a colossal Copepod, especially is the habitual agreement with certain Harpacticidx very striking. Lilie as in those last, the boly is extraordinarily flexible, especially in dorsal direction, and may ofen be so strongly bent that the candal branches come into contact with the frontal plate. The movement takes place in jerks, with powerful and tolerably rythmical strokes of the swimming feet, by which the body is drawn forwards with pretty considerable speed. The reprodnctively ripe males are extraordinarily active in their movements, and frequently make long excursions in the water. On the other hand, the females and the not yet fully developed males remain, as a rule. at the bottom, and move here among the material of the bottom, generally on the side. In doing this they understand to conceal themselves with great dexterity in the mud, or the decomposing remains of sea-reed which covers it, so that it is not at all easy to search them out, in spite of the not inconsiderable size. We find them easiest by pouring the collected bottom material into a flat ressel, along with an inconsiderable quantity of sea-water. The specimens present will then, especially if the bottom stufi is stirred a little up, soon show themselves on the surface of the water, and as they, like several other Crustaceans. are unable to swim downwards in the water again after they have first come into contact witl the air. they may with ease be collected in the live state. If we place, preferably a young individual, in a suitable quantity of sea-water, under the microscope, we can then more elosely study the varions features 
regelmassig svingende rythmisk Bevægelse, som km for kortere Tid ganske kan stoppes. Denne Bevægelse har væsentlig respiratoristie Formaal, men er ogsaa af stor Betydning for Næringsoptagelsen. Ved disse Lemmer's Spil frembringes nemlig indenfor Rygskjoldets Valvler en fortil gaaende Stromning af Vandet, hvormed de Smaapartikler, der tjener Dyret til Fode, hvirvles indenfor Munddelenes Omraade. Vandet strommer hermder $i$ en continuerlig Strom ud fra Pygskjoldets forreste Ende, nedenfor Paudepladen. Derfor holdes denme altid, under Branchialfoddernes Bevægelse, lige fortil strakt, medens den i Regelen, saasnart Bevægelsen stopper, boies nedad, invorved den som en Klap tillukker den forreste Aabning af Rygskjoldet.

Udbredning. Arten synes at have en ganske overorlentlig vid geographisk Udbredning. Fornden red Norges Kyster er den observeret $i$ de arktiske Have, ved Gronland, Spitsbergen og Island, fremdeles ved Nordamerikas Ostkyst, ved de britiske Der, og idethele langs hele Europas Nordso- og Atlanterhavskyst, ligesom den ogsaa forekommer i Middelhavet, livor den paa sine Steder, som i Golfen ved Neapel, ikle er nalmindelig.

\section{Nebalia typhlops. G. O. Sar's.}

(I'l. 1, Fig. 4, Pl. IV, Fig. ?-19).

Nebulia typhlops, G. O. Sars, Nye Iybvandscrustaceer fra Lo foten; Chr. Yja. Selsk. Forl. f. 1569.

Artscharacteristik. Meget lig foregaaende Art i sin almindelige Habitus, skjondt maaske lidt mere undersatsig af Form. Rygskjoldet, seet fra Siden, af oval For'm, lidt lavere fortil og med de nedre Kanter jevnt bnede paa Midten. Pandepladen vel udviklet, aflang oval, stærlit hvælvet oventil og forsynet i Enden med et spidst tornformigt Fremspring, Ginene yderst smaa og rudimentre, lioniskt tillobende i Enden, og uden Spor af Pigment eller Synselementer. De ovre Folere (hos Humnen) forholdsvis kortere end hos foregaaende Art. med Svoben neppe længere end Skaftet og kun sammensat af 10 Led, det bladformige Appendix temmelig forlænget, næsten halvt saa langt som Svouen. De nedre Folere omtrent som los $N$. bipes. Branchial. fodderne med Endopoditen meget tynd og strerkt forlænget, omboiet i Spidsen og forsynet med lange divergerende Fjærborster"; Epipoditen med den dor. of life, and may through the semi-transparent integuments observe the pulsations of the heart, the peristaltic movements of the intestine, and the play of the branchial feet. These last, which have no influence whatsoever on the locomotion, we will usually find in a regular, swinging, rythmical motion, which only for a short time may be quite stopped. That motion has chiefly a respiratory function, but is also of great importance in securing the nourishment. By the play of these appendage. there is produced, namely, inside of the valves of the carapace, a forward current of the water by which the small particles that serve the animal for food are drawn within the area of the oral parts. The water during this flows ont in a continuous stream from the foremost extremity of the carapace below the frontal plate. It is therefore always held stretched straight forward during the motion of the branchial feet, whilst, as a rule, as soon as the motion ceases, it is bent downwards, by which action it, like a cover, closes the foremost aperture of the caraprace.

Distribution. The species seems to have quite an extraordinarily extensive geographical distribution. Besides on the Norwegian coasts, it is observed in the Arctic seas, at Greenland, Spitzbergen and Iceland; further, off the east coast of North America, at the British Islands, and, as a whole, along the entire North sea and Atlantic coasts of Europe; and, it likewise occurs in the Mediterranean, where it, in certain places, such as the Gulf of Naples, is not uncommon.

\section{Nebalia typhlops. G. O. Sars.}

(P1. I, fig. 4, Pl. IV, figs 9-19).

Nebalia typhlops, G. O. Sars, Nye Drbrandscrustaceear fra Lofoten; Chr. Vid. Selsk. Forl. f. 1869

Specific Characters. Very like the preceding species in its general habitus, althongh, perhaps, a little more stmmpy in shape. Carapace, riewed laterally, oval in form, a little lower in front, and with the lower elges evenly curved at the middle. Frontal plate well developed, oblongo-oval, strongly arched above, and funished at the extremity with a pointed spiniform prominence. Eyes extremely small and rudimentary, passing into conical form at the end, and without trace of pigment or visual elements. Snperior antennx (in female) relatively shorter than in the preceding species, with the flagellum scarcely longer than the pedmole and only composed of 10 joints; the lamelliform appendage rather prolonged. almost half the length of the Hagellum. Inferior antennæ abont as in $N$. lines. Branchial feet with the entopodite very slender and greatly prolonged, 
sale Lob betydelig storre end den ventrale. Forste Par Svommefodder med Yderkanten af den ydre Gren kun forsynet med 3 Smaatænder, nmiddelbart orenfor den 1ste Eudetorn. Halegrenene noget kortere end de 2 bagerste Segmenter tilsammen, Farven hvidagtig, nden Pigmentering. Dyrets Længde $9 \mathrm{~nm}$.

Bemærkninger. Den her omhandlede Art staar vistnok meget nær foregaaende, men er dog let kjendelig fra samme ved forskjellige vel ndprægede Characterer, hvoraf navnlig maa fremhæves den l'udimentære Beskaffenhed af Øinene og Pandepladens Form og Bevæbuing. Ogsaa i Bygningen af de forskjellige Kropsvellhæing vil man ved en noiere Sammenligning kunne paavise en Del mindre Differentser fra samme hos $N$. bipes.

Beskrivelse. Legemets Form hos Humnen (se Pl. 1, Fig. 4) stemmer idethele temmelig noie overens med samme hos foregaaende Art, skjondt den maaske er noget mindre slank. Hannen er endnu ubekjendt. Rygsskjoldet er som hos .N. bipes stærkt sammentrykt og viser, seet fra Siden, en temmelig regelmæssig oval Forn, med den storste Hoide, der er noget storre end den halve Længde, omtent paa Widten. De frie Kanter af Valvlerne er nedentil jevnt buede og damner helt fortil en stærk Krum. ning, inden de stoder sammen ved Basis af Pandepladen. Bagtil viser de sig skrat afskaarne i Retningen forfra bagtil, og de nedre bagre Hjorner af Rygskjoldet dauner derfor, som hos foregaaende Art, til hver Side en smalt afrundet Lap, der dækker Siderne af Bagkroppen og næsten rækker til Begynlelsen af Halen. Pandepladen (se Pl. IV, Fig. 9, 10) er rel udviklet og af meget smal tungedannet Form, temmelig stærkt hvælvet oventil, og forsynet i Enden med et spidst tornformigt Fremspring, der danner Fortsættelsen af en langs den nedre Side lobende Kjol. Sidste Bagkropssegment har, som hos foregaaende Art, et Par smaa afrundede Epimerer og er ligesom de 3 folgende Halesegmenter grovt sagtakket i den bagre Kant. Halegrenene er noget kortere end de 2 foregaaende Segmenter tilsanmen. forovrigt af fuldkommen samme Bygning som hos foregaaende Art.

Oinene (se PI. IV, Fig. 9, 11) ndmærker sig i hoi Grad red sin ringe Størrelse og rudimentære Beskatfenhed, og rager kun lidet frem fra Rygskjoldet, hvorfor de let kan forlisees. De er, som hos V. bipes, dækkerle oventil af en skjælformig, spidst ndlobeude Plade. Selve Oienstilken er af konisk recurved at the tip and furnished with long divergent plumose bristles; the epipodite with the dorsal lobe considerably larger than the ventral one. First pair of swimming feet with the exterior edge of the onter branch furnished only with 3 small teeth immediately above the 1 st terminal spine. Caudal rami somewhat shorter than the 2 backmost segments taken together. Colour whitish, without pigmentation. Length of the animal $9 \mathrm{~mm}$.

Remarks. The species here spoken of is certainly very nearly allied to the preceding one, but still is easily distinguishable from same by various well defined characteristics, of which may especially be noticed the rudimentary character of the eyes, and the sliape and armature of the frontal plate. Also in the structure of the varions appendages of the body, we may, on a closer comparison, be able to notice a nnmber of smaller differences in the same from those of $N$. bipes.

Description. The shape of the body of the female (see Pl. I, fig. 4) agrees, on the whole, pretty exactly with that of the preceding species, although it is, perhaps, somewhat less slender. The male is yet unknown. The carapace is, as in $N$. bipes, strongly compressed and exhibits, viewed laterally, a pretty regular, oval form; with the greatest height, which is somewhat more than half the length, at about the middle. The free elges of the valves are evenly curved below, and form, quite in front, a strong curvature until they nnite at the base of the frontal plate. At the back they show themselves obliquely truncated in a direction from back to front, and the lower posterior corners of the carapace form, therefore, as in the preceding species, on each side, a narrow rounded lobe which eover's the sides of the metasome and extends almost to the comnencement of the urosome. The frontal plate (see Pl. IV, figs. 9,10) is well developed and of very narrow linguiform shape, pretty strongly arched above, and furnished at the extremity with a pointed spiniform prominence which forms the continuation of a carnia that roms along the lower side. The last segment of the metasome has, as in the preceding species, a pair of small rounded epimera, and are, as well as the 3 succeeding candal segments, coarsely serrated on the posterior edge. The candal rami are somewhat shorter than the 2 preceding segments taken together, otherwise of perfectly the same structure as in the preceding species.

The eyes (see Pl. IV, figs. 9, 11) distinguish themselves in a high degree by their small size and rudimentary character, and only project a little forward from the carapace; for which reason they may easily be overlooked. They are, as in N. bines, covered above with a squamiform plate rumning 
Form, uden nogen bemærkelig Opsvulmning i Enden. Af Pigment eller Synselementer er der ikke det ringeste Spor at opdage.

De ovre Folere (se Pl. IV, Fig. 9) er forholdsvis kortere end hos foregaaende Art, forovrigt af en meget lignende Bygning. Svoben er kun lidet længere end Skaftet og kun sammensat af 10 Led. Det skjælformige Appendix er derimod forholdsvis storre end hos foregaaende Art, næsten balvt saa langt som Svoben, og af en mere aflang Form, forovrigt forsynet med en lignende kostformig Besætning af stive Borster.

De nedre Folere (ibid.) stemmer idethele saa noie overens med samme hos foregaaende Art, at en noiere Beskrivelse er unødvendig.

Ogsaa Mnnddelene viser en meget lignende Bygning, skjøndt enkelte mindre Differentser ved noiere Sammenligning lader sig paavise. Saaledes er Mandiblernes Palper (se Fig. 12) forholdsvis noget min(lre, og deres 2det Led har kun en enkelt meget stærk Borste i den ydre Kant nær Spidsen. Første Par Kjæver (Fig. 13) er ligeledes noget svagere udviklede, men forovrigt paa det nærmeste af samme Udseende som hos $N$. lipes. Paa 2det Par Kjæver (Fig. 14) er Endognathens 2 Led kun ufuldkomment sondrede og næsten af ens Længe; Exognathen er neppe mere end halvt saa lang og har et ringere Antal Randborster end hos $N$. bipes.

Branchialfodderne (Fig. 15, 16) udmærker sig navnlig ved Endopoditens Længde og Tyndhed. Paa de forreste Par overrager den betydeligt Exopoditen og har sidste Led stærkt omboiet sant besat med særdeles lange divergerende Fiærbjorster. Exopoditen er af skjævt oval Form og forsynet med flere Randborster, hvoraf de yderste er tydeligt cilierede. Epipoditen har paa alle Par den dorsale Lap betydelig mindre end den ventrale, medens iet omvendte var Tilfældet hos foregaaende Art. Som hos denne, bemærkes nogen Forskjel i de forskjellige Hoveddeles indbyrdes Forbold paa de forsljellige Par Branchialfodder. Sidste Par (Fig. 16) har saaledes et fra 1ste Par (Fig. 15) temmelig afvigende Udseende og skiller sig ogsaa kjendeligt fra det tilsvarende hos $N$. bipes (PI. III, Fig. (j). Endopoditen er her, i Modsætning til hrad Tilfældet er med de ovrige Par, meget kort og uden nogen tydelig Led. deling, og Exopoditen er ligeledes forholdsvis mindre end hos $N$. bipes og i Yderkanten forsynet med en Rad af cilierede Borster. Fem lignende Fjær borster findes ogsaa paa den korte $\mathrm{og}$ tilrundede ventrale Lap af Epipoditen.

Svommefodderne forholder sig i alt væsentligt som hos Y. lipes; kun er ide illethele af en noget ont to a point. The ocular stem itself is of conical shape, without any noticeable swelling at the extremity. There is not the slightest trace of pigment or visual elements to be discovered.

The superior antennæ (see Pl.IV, fig. 9) are relatively shorter than in the preceding species, otherwise of a very similar structure. The flagellum is only a little longer than the peduncle and is composed of only 10 joints. The squamiform appendage is, on the contrary, relatively larger than in the preceding species, almost half the length of the flagellnm and more oblong in form, otherwise furnished with a similar supply of stift bristles.

The inferior antennæ (ibid.) agree, upon the whole, so exactly with those of the preceding species that a more detailed description is unnecessary.

The oral parts also exhibit a very similar structure, although upon a closer comparison a few small divergencies may lue observed. Thus the palpi of the mandibles (see fig. 12) are relatively somewhat smaller, and their ind joint has only a single, very strong bristle on the onter edge, near the tip. The first pair of maxille (fig. 13) are likewise somewhat more faintly developed; but otherwise pretty nearly of the samme appearance as in $\Lambda$. bipes. In the 2nd pair of maxillæ the 2 joints of the endognath are only imperfectly separated and almost equal in length; the exognath is scarcely more than half as long, and has a smaller number of marginal bristles than in $N$. bipes.

The branchial feet (fig. 15, 16) especially dis tinguish themselves by the length and slenderness of the endopodite. In the furemost pairs it considerably overreaches the exopodite, and has the terminal joint strongly recurved, and also beset with particularly long, diverging plumose bristles. The exopodite is of oblique, oval form, and furnished with several marginal bristles, of which the outermost are distinctly ciliuted. The epipodite has, in all pairs, the dorsal lobe considerably smaller than the ventral one, whilst the opposite was the case in the preceding species. As in that, there is observed some difference in the mutual relations of the various chief parts of the different pairs of the branchial feet. The last pair (fig. 16) have thus a pretty divergent appearance from the 1st pair (fig. 15 ), and distinguish themselves perceptibly from the corresponding pair in $N$. lipes $P l$. III, fig. 6 ). The endopodite is here, in contrast to what is the case in the other pairs, very short, and without any distinct articular division; and the exopodite is likewise relatively smaller than in $\mathrm{N}$. bipes, and is furnished on the outer edge with a series of ciliated bristles. Five similar plumose bristles are also found on the short and rounderl ventral labe of the epipodite.

The swimming feet have, in all essential respects, the same structure as in $N$. bipes; only that they 
mere smækker Form. Paa 1ste Par (Fig. 17) er der dog den Forskjel. at Tderkanten af den ydre Gren kun har, umiddelbart ovenfor den yderste Torn, 3 Smaapigge, medens hos $N$. bipes hele denne Kant er tæt og regelmæssigt pigget.

De 2 Par rudimentære Halefodder (Fig. 18, 19) viser ligeledes et Udseende, meget nær overensstemmende med samme hos denne Art, alene med den Forskjel, at Tornernes Antal paa begge er noget ringere.

Farven el hos det levende Dyr lividagtig, uden nogen bemærkelig Pigmentering. Integumenterne er tynde og gjennemsigtige, saa de indre Organer temmelig tydeligt skinner igjemem.

Eggene i Klækkehulen er forholdsvis store og af en meget bleg gulagtig Farve.

Længden af den ægbærende Hun er kun 9 mm., Storrelsen er altsaa betydelig ringere en hos $\mathrm{N}$. bipes.

Forekomst. Jeg har hidtil kum seet 3 Expl. af denne Art, alle Hunner. De blev tagne til forskjellige Tider paa 3 vidt adskilte Punkter af vor Kyst, det ene ved Hvitingso, ndenfor Stavanger, det 2 det i Trondhjemsfjorden, og det 3die red Lofoten. Exemplarerue forekom paa alle 3 Steder i et Dyb af fra 150-200 Favne og paa bled Lerbund. Arten synes herefter at maatte betragtes som en udpræget Dybvandsform, hvad der ogsaa kan shuttes af de ufuldkomment udviklede Synsredskaber. Udenfor Norge er den endnu ikke hleven observeret. are altogether of a somewhat more slender form. In the 1st pair (fig. 17) there is, however, the difference, that the outer edge of the outer branch has, immediately above the outermost spine, only 3 small spikes, whilst in $N$. bipes the whole of that edge is closely and regularly spiked.

The 2 pairs of rudimentary candal feet (figs. $18,19)$ likewise present an appearance very nearly correspondent with those in that species, with the difference only, that the number of spines on both is somewhat smaller.

The colon in the living state of the animal is whitish, without any noticeable pigmentation. The integuments are thin and transparent, so that the internal organs are pretty distinetly visible through them. The ora in the hatching cavity are relatively large, and of a very pale yellowish colour.

The length of the ovigerons female is only 9 mm. The size is thus considerably less than in $N$. bipes.

Distribution. I have hitherto only seen 3 specimens of this species, all females. They were taken at different times, at 3 widely separated places off our coast; the one at Hvitingso, off Stavanger, the 2nd in the Trondhjemsfjord, and the srd at the Lofoten isles. The specimens were obtained, at all the 3 places, at a depth of from 150-200 fathoms and on soft clay bottom. It appears from this, that the species must be considered as a distinguished deepwater form. which may also be gathered from the imperfectly developed visual apparatus. Out of Norway it has not hitherto been observed. 


\section{Subordo II. \\ PHYLLOPODA.}

Character. Branchiopoder af meget forskjellig Kropsform, dels nden. dels med Rygskjold, det sidste undertiden ndviklet $\mathrm{i}$ Form af 2 voluminose, det hele Dyr omslnttende Valvler. Legemets Segmentation forskjellig hos de forskjellige Former. Oinene dels stilkede, dels sessile, undertiden næsten sammensmeltede; et mediant Enkeltoie (ocellus) tilstede. Folerne i Regelen meget nlige ndviklede; 1ste Par som oftest meget smaa og udelukkende sensitive; 2det Par af forskjellig Bygning, snart rudimentære (hos det voxne Dyr), snart udviklede til kraftige 2grenede Aarer, eller til tangformige Griberedskaber (hos Hannen). Overlæben vel udviklet, klapformig; Underlæben i Regelen manglende. Kindbakkerne hos det ndviklede Dyr uden Palpe. To Par Kjæver tilstede, begge smaa og af forholdsvis simpel Bygning. Alle bag Munddelene folgende liemmer respiratoriske, af tilnærmelsesvis uniform Bygning og bladdannet lappet Form; deres Tal meget forskjelligt, undertiden abnormt stort. Udviklingen i Regelen en compliceret Metamorphose, begyndende med et frit NauplinsStadium. Indlandsdyr.

Bemærkninger. Denne Underorden omfatter et ikke meget stort Antal Dyreformer, der imidlertid viser meget væsentlige Forskjelligheder, saavel hvad let ydre Udseende som den indre Bygning angaar. Hvad der hovedsageligt characteriserer deme Afdeling af Branchiopoder, og har givet dem sit Navn, er Structuren af de bag Munddelene folgende Lemmer, der alle viser et lignende blarlformigt og lappet Udseende som de til Midtkroppen hos Phyllocariderne horende saakaldte Branchialfodiler. Da de tillige i sin Function er ndpræget respiratoriske, benævnes

\section{Sudordo II. PHYLLOPODA.}

Characters. Branchiopods of very various shape, partly withont and partly with carapace, the lastnamed sometimes developed in the form of 2 voluminous valves enveloping the entire animal. The segmentation of the body different in the various forms. Eyes partly pedunculated, partly sessile, sometimes nearly coalescent; a median single eye (ocellus) present. Antennæ, as a rule, very unequally developed; 1st pair most frequently very small and exclusively sensitory; 2nd pair of variable structure, sometimes rudimentary (in the alult animal), sometimes developed to powerful, 2-branched oars, or to pincer-shaped prehensile apparatus (in the male). Anterior lip well developed, flap-formed; posterior lip, as a rule, wanting. Mandibles, in the developed animal devoid of palpi. Two pairs of max. illæ present, both small and of relatively simple structure. All the appendages placed behind the oral parts respiratory, of approximately uniform structure and leaf-formed shape; their number very variable, sometimes abnormally large. The development usually a complicated metamorphosis, commencing with a free Nauplius-stage. Inland animals.

Remarks. This sub-order includes a not very large number of animal forms, which exhibit, however, very material divergencies, both in respect of the external appearance as well as in the internal structure. What chiefly characterizes this division of Branchiopods and has gevin to it its designation is, the structure of the appendages placed behind the oral parts, which all exhibit a similar leaf-shaped and lobed appearance as the so-called branchial-feet pertaining to the mesosome in the Pliyllocarida. As they are, besiles, in their function prominently 
de ogsaa her paa samme Maade. Forskjellen er altsaa, at her alle bag Munddelene folgende Leminer er ægte Branchialfodder, medens dette hos Phyllocariderne kun er Tilfældet med en Del af dem. I Folernes Bygning er der saa stor Forskjel hos de forskjellige Former, at intet andet bestemt fælles Charactertræk kan anfores end, at det 1ste Par udelnkkende er sensitive og derfor af en meget tander Structur. Ogsaa Oinenes Bygning er meget forskjellig, idet de snart er stilkede som hos Phyllocariderne, snar't sessile, snart sammensmeltede til et enkelt i det indre af Hovedet beliggende Organ. Characte ristisk ligeoverfor Phyllocariderne er Tilstederærelsen af et mediant Enkeltoie (ocellus). Angaaende Wunddelenes Structur, kan fremhæres Mangelen af Palper paa Kindbakkerne, og den forholdsvis simple Brgming af de 2 Par Kiærer.

De hidtil bekjendte Phyllopoder vil passende kunne fordeles paa 3 storre Afdelinger, for hrilke jeg allerede i $1867^{1}$ ) har foreslaaet folgende Benæynelser: Anostraca, Notostraca og Conchostraca. Forskjellen mellem disse Afdelinger er saa stor og giennemgribende, at de ikke, som af ite fleste Forskere giort, kan opfattes som blotte Familier, men ubetinget bor tillægges en langt hoiere systematisk Værdi (Tribus eller Sectioner). Til enhver af disse Grupper horer et meget begrændset Antal af Slægter, som delvis lader sig fordele paa flere Familier.

De herhen horende Slægttypers Faatallighed og i Regelen overordentlig skarpt ndpregede Forskiel, i Forbindelse med deres sporadiske Forekomst paa vidt adskilte Localiteter, synes at tyde hen paa, at vi i Phyllopoderne har de sidste divergerende Grene af en uddoende Tyrgruppe, som rimeligvis, at domme efter flere palæontologiske F'und, har været langt rigere repræsenteret i tilligere Jordperioder. Ogsaa af disse Dyrs Organisation og Udvikling synes man at være berettiget til at slutte, at de maa rære af meget gammel Oprindelse. Det yderlig variable Antal af Kropssegmenter og af Lemmer, disse sidstes uniforme Bygning, len oftest knn lidet skarpt udprægede Sondring af Legemet i tydeligt begræudsede Kropsafsnit, alt dette er Characterer, der aabenbart henpeger paa primitive Tilstande, hvori endnu ikke de bos de moderne Crustacegrupper gjældende Forhold rigtigt har fixeret sig. Phyllupoderne uninder i deme Henseende ikle saa lidet om de ældgamle Trilobiter, ligesom der ialfald hos Afdelingen Notostraca er en umiskjendelig habitnel Lighed med de ligeledes langt op i den geologiske Tid gaaende

1) G. O sars. Histoire naturelle des Crustacés d'eau douce de Norvège, I. respiratory, they are also named here in the same manner. The difference, therefore, is, that here all the appendages placed behind the oral parts are real branchial feet, while in the Phyllocarida that is only the case with a part of them. In the strncture of the antennæ there is such a great difference in the various forms, that no other certain characteristic feature in common can be given, than that the 1st pair are exclusively sensitory and therefore of a very delicate structure. The structure of the eyes also is very different, as they are sometimes pedunculated, as in the Phyllocarida, sometimes sessile, sometimes coalescent to a single-organ situated in the interior of the hearl. The presence of a single median eye (ocellus) is a characteristic feature in contrast with the Phyllocarida. Regarding the structure of the oral parts may be mentioned, the absence of palpi on the mandibles, and the relatively simple structure of the 2 pairs of maxiliæ.

The Phyllopods litherto known may suitably he assigned to 3 large divisions, for which the anthor. as early as $\left.1867^{1}\right)$, proposed the following designations: Anostraca, Notostraca and Conchostraca. The rlifference between those divisions is thronghont, so great, that they cannot be regarded as families only, as has been done by most writers, but ought, evidently, to be assigned a far ligher systematic value (Tribus or Sections). To each of these groups there pertain a very limiterl number of genera, which to some extent may be referred to several families

The pancity in number of the generic types pertaining hereto, and the, as a rule, extraordinarily sharply distingnished difference, in connection with their sporadic occurrence in widely separated localities, seems to give an indication that in the $\mathrm{Ph}_{2}-1$ lopods we have the last diverging branches of a vanishing animal group, which, probably, judging by several palæontological discoveries, has been far nore abnndantly representerl in earlier periods of our earth's history. From the organisation and development, also, of these animals, it seems as if we were warranted in conclnding that they must be of very old urigin. The extremely variable number of body segments and of appendages; the nuiform structure of the last-named; the nsnally only little sharply distinguished separation of the body in distinctly defined divisions, are all characteristics that evidently point to primitive conditions, in which the regulating relations of the modern gromps of crustaceans had not yet been thoroughly consolidated. The Phylloporls remind us in that respect, not so little of the ancient Trilobites, while, also, there, in

1) G. O. Sars, Histoire naturelle des Crustacés d'eau douce le Norrege, I. 
Dolkhaler (Xiphosura). Det synes altsaa som om disse Dyr, uagtet deres Organisation idethele har naret et forholdsvis meget hoit Udviklingstrin, dog ved Siden heraf har conserveret flere af de primitive Characterer, der maa antages at have udmærket de ældgamle Stamformer, hvorfra alle de moderne Crustaceel i sidste Instans har taget sit Udspring. Ogsaa Udviklingen synes at stotte denne baade af Prof. Claus og Dr. Dohrn fremholdte Anskuelse. Saagodtsom hos alle Phyllopoder begynder nemlig den frie Udvikling med det overordentlig simple saakaldte Nauplius Stadium, og Larven gjennemgaar derpaa en Række af successive Omformninger, der lidt efter lirt forbereder Phyllopordestadiet. Det bor log her bemærkes, at Dr. Packard i sit fortjenstfulle Værk over Nordamerika's Phyllopoder hævder en herfra meget forskjellig Anskuelse. Efter denne Naturforskers Mening er Phyllopoderne tværtimod af meget ny Oprindelse og fiemstaaet red en videre Udvikling af Cladocer-Typen. Dette kunde maaske til Noul lade sig hore, hror der er Sporgsmaal om den ene af Phyllopodernes:3 Sectioner, de saakaldte Conchostraca, ler ganske sikkert viser en meget udprreget Affinitet til Cladocererne. Men langt vanskeligere bliver det at faa udledet de 2 ovrige Phyllopode-Typer fra Cladocererne. Der gives iklie en eneste Cladncer, der viser den fjerneste Tilnærmelse til de for Grupperne Anostraca og Notostraca characteristiske Eiendommeligheder, og det gaar heller ikke an, at aflede disse 2 Typer fra den Bdie Conchostraca. De 3 Phyllopodetyper staar i Virkelig. heden paa en Maade helt isolerede og har rimeligris et meget forskjelligt Udspring. Langt naturligere end den af Packard fremsatte Hypothese om Phyllopodernes Afstamning fra Cladocererne, synes det mig at rære at vende Sagen helt om, ug altsaa antage, at Cladocererne er af yngre Oprindelse end Phyllopoderne og har ndviklet sig sım en Sidegren fra Gruppen Conchostraca. Raadsperger vi Palæontologien, vil ialfald intet Modbevis mod en sadan Antagelse kunne hentes herfra; tværtimorl. Medens man nemlig endnu ikke kjender en eneste Cladocer i fossil Tilstand, finder man talrige fossile Skaller af utvivlsomme conchostrake Plyllopoder, nærmest henhorende til Slægten Estherin, lige op til den Devoniske Periode; noget der jo viser, at ialfald denne Gruppe af Phylloporler ikke kan være af saa ny Oprindelse, som man efter Packards Hypothese synes at maatte antage. $\mathrm{Nu}$ er der forskjellige morphologiske Forhold, der gior det huist usandsynligt at antage, at Gruppen Conchostraca skulde repræsentere de aldste og oprindeligste Phyllopoder. Vi kommer arl denne Vei snarere til en stik modsat Slutning, nemlig at demne Gruppe er af en betydelig yngre Oprindelse end de 2 ovrige. At man ikke kjender nogen forverdenske Former af disse sidste Grupper, kan naturligt forklares af de herhen ho- the division Notostraca, at any rate, is an unmistakable habitual resemblance with the sword-tails (Xiphosura), likewise passing far back in geological times It appears therefore, as if these animals, although their organisation has, upon the whole. attained, relatively, a very high stage of development, still have retained several of the primitive characteristics which must be assumed to have distinguished the ancient ancestors, from which all the modern crustaceans have finally had their origin. The development also seems to support that view, advocaterl both by Prof. Claus and Dr. Dohrn. In almost all the Phyllopods the free development hegins, namely, with the extraordinarily simple so-called Namplins stage; and the larva thereupon undergoes a series of successive transformations. which, little by little, prepare the phyllopod-stage. It ought to be noted here, how ever, that Dr. Packard in his admirable work upon the Phyllopods of North America, maintains a very different view. According to the opinion of that naturalist, the Phyllopods are, on the contrary, of very late origin, and produced by a further development of the Cladocera-type. That might perhaps, in the absence of anything better, be accepted, when the question concerms one of the 3 sections of Phyllopods, the so-called Conchostraca, which quite certainly exhibits a very distingnished affinity to the Claclocera. But far more difficult does it become, to trace the 2 other phyllopod-types from the Cladocera. There is not a single Cladoceran that exhibits the slightest approximation to the characteristics peculiar to the groups Anostraca and Notostraca and neither is it permitted for ns to trace these 2 types from the 3 rd, the Conchostraca. The 3 types of Phyllopods stand in reality, in a measure, quite isolated, and probably have a very different origin. Far more natural than the lyypothesis of the derivation of the Phyllopods from the Cladocera, presented by Packard, does it appear, to me, to be, to quite reverse the case, and consequently assume that the Cladocera are of later origin than the Phyllopods and have become developed, as a lateral branch, from the group Conchostraca. If we consult pralæontology, we will, at any rate, find no testimony rebutting such an assumption to be obtained therefrom; on the contrary, while we do not yet know of a single Cladoceran in fossil condition, we find nnmerons fossil remains of indubitable conchostracan Phylloporls most closely approaching to the genus Estheria, even up to the Devonian period; a fact that rertainly shows that that group of Phyllopods. at any rate, cannot be of such late origin as we, according to Packard's hypothesis, seem obliged to suppose. Now there are various morphological relations that make it extremely improbable to suppose that the group Conchostraca represents the oldest 
rende Dyrs lidet faste Integumenter, der neppe er egnede til at opbevares i fossil Tilstand. Dog maa det her bemærkes, at det langt fra er sikkert, at alle de ældgamle, fordetmeste siluriske Former, der af Packard henregnes til Phyllocariderne, virkelig horer herhen. Enkelte af dem har ialfald habitnelt, ved sit flade Rygskjold og tildels Mangelen af den for Phyllocariderne characteristiske Pandeplade, en vel saa stor Lighed med notostrake Phyllopoder (Apus), og kan derfor muligvis ligesaa sandsynligt have hørt herhen. Da man af ingen af disse fossile Former kjender Lemmerne, maa deres rette systematiske Stilling endnu blive at betragte som et aabent Sporgsmaal.

Alle ægte Phyllopoder er Indlandsformer og forekommer som oftest i ganske smaa og grunde Ferskrandsansamlinger", der om Sommeren gansk eller delvis udtørres. Arterne af Slægten Artemia er eiendommelige for clet stærist saltholdige Vand i de saakaldte Saliner. I Havet existerer der derimod for Tiden ingen Phyllopoder.

Angaaende disse Dyrs Forplantningsmaade og Urvikling, saa stoder vi her paa nange eiendommelige og interessante Forhold, ligesom deres sporadiske Forekounst, Udbredningsforhold og Levevis idethele frembyder yderst mærkværdige Ting, som neppe endnu er tilstrækkeligt forklaret. Naar hertil kommer deres ofte meget bizarre Udseende, elegante $\mathrm{Be}^{-}$ vægelser og eiendommelige Organisation, synes der virkelig at være Grund for med Packard at anse dem for de interessanteste af alle Crustaceer.

Skjondt der til Norges Fanna kun horer ialt 5 Former, er dog alle de 3 ovenuævnte Hovedgrupper repræsenterede, og enluver af de norske Former repræsenterer desnden for sig en særskilt Familie. and most original Phyllopods. We arrive in that way. at, rather, a quite contrary conclusion, namely that that group is of considerably younger origin than the 2 others. That we are igmorant of any primeval forms of these lastnamed groups may be naturally explained by the little firm nature of the integuments of the animals pertaining hereto, which are scarcely adapted for preservation in fossil condition. Still it must be noted here that it is far from certain that all the ancient, chiefly silurian forms, which are assigned by Packard to the Phyllocarida, really pertain thereto. A few of them have, at any rate, in habitus, by their flat carapace and partly from the absence of the frontal plate characteristic of the Phyllocarida: a rather stronger resemblance to notostracan Phyllopods (Apns), and may therefore just as probably have possibly pertained thereto. As we do not know the appendages from any of these fossil forms, their correct systematic position must still be considered an open question.

All genuine Phyllopods are inland forms, and usually appear in quite small and shallow collections of fresh-water, which in summer quite, or partially, dry up. The species of the genns. Artemiu is peculiar to the strongly salt water in the so-ealled salines. In the ocean there exist, on the other hand, at the present time, no Phyllopods.

Regarding the method of reproduction of these animals and their development, we come here upon many peculiar and interesting relations, while also their sporadic appearance, distributive relations, and mode of life upon the whole, present extremely remarkable things which are scarcely yet sufficiently elucidated. When to this is added their frequently very bizarre appearance, the elegance of their movements and the peculiar organisation, there seems really to be reason for, like Packard, considering them to be the most interesting of all crustaceans.

Although there only pertain 5 forms altogether to the fauna of Norway, the 3 above named chief groups are, lowever, all represented; and each of the Norwegian forms represents of itself, besides, a separate family. 


\section{Sectio I. Anostraca.}

\author{
(Nogne Phyllopoder).
}

Syn: Phyllopoda pisciformia.

Character. Legemet forlænget, meget blodt og boieligt, mere eller mindre ormformigt, uden Spor af noget Rygskjold eller Skal. Legemets Segmentering temmelig uniform, dog med tydelig Adskillelse i Hoved, Midtkrop og Hale. Dinene tycleligt stilkede og berægelige, af en lignende Broning som loos $N e$ balia. Forste Par Folere meget smaa, traadformige; 2det Par hos Hunneu mere ellel mindre rudimentære, fligformige, hos Hannen omdanuele til kiloformige Griberedskaber. Kindbakkerne med stump riflet Tyggeflade, nden tydelige Trender. Branchialforlderne uden Coxallap, men med 1 eller 2 Drakblade ved Basis paa den ydre Side, alle af noget nær ens Bygning. ndpræget respiratoriske, men samtidigt ogsaa locomotoriske. Halen nden Lemmer, dens forreste Segmenter delvis sammenvoxne og givende Udspring for de ydre Kjonsvedhæng: hos Hunnen en enkelt, mere eller mindre sakformig Egbeholder med terminal Aabning, los Hannen 2 fuldstæudig skilte og meget smaa Copulationsredskaber. Udviklingen en compliceret Metamorphose begyndende med et frit Nanplins-Stadium.

Bemærkninger. De til demne Afdeling horende Phyllopoder er let kjendelige ved sit langstrakte og blode, næsten ormlignende Legeme, ved Mangelen af et Rygskjold eller Skal, verl de tydeligt stilkede Oine, ved den eiendommelige Bygning af 2det Pàr Folere hos de to Kjon, endelig ved den eiendomme. lige Beskaffenhed af de ydre Kjousvedhæng. Man kan fordele de hidtil bekjendte Former paa $3 \mathrm{Fa}$ milie1: Branchipodide. Thamnocephatide og Polyartemiidce. Kun den forste og sidste af disse Familier e1 repræsenterede i Norges Fauna. Den 3die Familie er opstillet af Packard for en mærkelig nordamerikansk Form, Thamnocephalus platyurus Packard, ler, fornden ved de eiendommelige Frontalvedhæng, ndmærker sig i hoi Grad derved, at Halen ender med en enkelt bred horizontal Svommeplade.

\section{Sectio I. Anostraca.}

(Naked Phyllopods).

Syn: Phyllopoda pisciformia.

Characters. Body prolonged, very soft and flexible, more or less vermiform, without trace of any carapace or shell. The segmentation of the body pretty uniform, but with distinct division between the head, the mesosome and the tail. Eyes distinctly pedumenlated and moveable, of similar structure to these in Vebalia. First pair of antennx very small, filiform. Second pair more or less rndimentary in the female, flap-shaped; transformed in the male to claw-formed prehensile apparatus. Manrlibles with blunt rifled masticatory surface, withont distinct teeth. Branchial feet without coxal lobe, but with one or two covering plates at the base on the outer side; all of somewhat miform structure, distinguished respiratory, but at same time also locomotive. Tail without appendages; the foremost segments partly coalescent and furnishing the origin for the onter sexual appendages: in the female a single, more or less sac-formed marsupinm with terminal aperture; in the male 2 completely separated and very small copulative appendages. The development a complicated metamorphosis, com mencing with a free Nauplius stage.

Remarks. The Phyllopods belonging to this division are easily recognizable by their elongate and soft, almost vermiform body, by the alsence of a carapace or shell, by the distinctly pedunculated eyes, by the peculiar structure of the 2nd pair of antenmæ in the two sexes and, finally, by the peculiar character of the onter sexual appendages. We may refer the hitherto known forms to 3 families: Branchipodide, Thammocephatide and Polyartemiide. Only the first and last named of these families are represented in the fauna of Norway. The 3rd family is established by Packard, to inclucle a remarkable North American form, Thamnocephalus platyurus, Packard, which, besides by its peculiar frontal appendages, distinguishes itself in a ligh degree, in that the tail terminates in a single, broad horizontal swimming plate. 


\section{Fam. 1. Branchipodidæ.}

Character. Legemet smalt cylindriskt, noget tykkere fortil, med Halen vel ndviklet og tydeligt segmenteret hos begge Kjon, endende med 2 borstebesatte Halegrene. Hannens Gribeantenner tydeligt segmenterede og i Regelen forsynede med en rudimentære.Bigren. Frontalvedhæng tilstede hos Hannen eller manglende. 11 Par Branchialfodder tilstede, alle med en enkelt sagtakket ydre Dækplade. Hnnnens Egheholder tydeligt sækformig og bagudrettet, ndspringende fra de 2 forreste Halesegmenter.

Bemærkninger. Til denne Familie hører ialt 5 Slægter, nemlig: Artemia Leach, Branchinecta, Verrill, Branchimes Schäffer, Chirocephalus Prevost og Streptocephalus Baird. Kun en af disse Slægter, Branchinectu, er repræsenteret i vor Fauna. Familien er hovedsageligt characteriseret ligeoverfor deu folgende Familie, Polyartemiule, ved den forskjellige Bygning af Hannens Gribeantemer, ved det betydelig ringere Antal Branchialfodder, ved Halens For'm, endelig ved Beskaff'enheden af Hunnens Eggebeholder. Fra Familien Tamnocephatidce, med hvem den kommer overens i Antallet af Branchialfodder, skiller den sig ved Legemets smækrere Form og navnlig ved Beskaffenheden af Halen.

Gen. Branchinecta, Verrill, 1869

Synn: Branchipus, Milne-Ertu: (ex parte).

Slægtscharacter. Legemet af særdeles slank Form, med Halen tynd og forlænget, bestaaende af 9 Segmenter, formden Halegrenene; de sidste forholdsvis korte. Hannens Gribeantenner simple, bestaaende af et tykt cylindriskt Skaft og en smal, kloformig, incladkrummet Endedel; Bigrenen meget liden, linudeformig. Ingen Frontalvedhæng tilstede. Branchialfodderne forholdsvis brede, med Exopoditen af afrundet oval Form, og den ydre Dækplade sagtakiket i Ranteine. Hunnens Eggebeholder særdeles smal og forlænget, næsten cylindrisk.

Bemærkninger. Denne af den amerikansle Forsker, Prof. Verrill, opstillede Slægt el væsentlig characteriseret ligeoverfor St. Branchimus Schätfer vel den overordentlig slanke Krropsform, ved Man-

\section{Fam. I. Branchipodidæ.}

Character. Body narrow cylindrical, somewhat thicker in front, with the tail well developed and distinctly segmented in both sexes, terminating in 2 bristle-beset candal rami. Prehensile antennæ of the male distinctly segmented, and usually furnished with a rudimentary sub-branch. Frontal appendages present in the male or awanting. 11 pairs of branchial féet present, all having a single serrated external covering plate. Marsupium of the female distinctly sac-formed, directed backwards, and issuing from the 2 foremost caudal segments.

Remarks. Five genera in all pertain to this family, namely: Artemia, Leacli; Branchinecta, Verrill; Branchipus, Schaeffer; Chirocephalus, Prevost, and Streptocephalus, Baird. Only one of these genera, Branchinecta, is represented in on fauna. The family is principally characterised, in contrast with the following family Polyartemiide. by the different structure of the prehensile antennæ of the male, by the considerably smaller number of branchial feet by the shape of the tail and, finally, by the character of the marsupium in the female. It distingnishes itself from the family Tamnocephalide, with which it agrees in the number of branchial feet, by the more slender form of the body, and especially in the character of the tail.

Gen. Branchinecta, Verrill, $1: 69$.

Sym: Branchipus, Mitne-Edu. (ex parte).

Generic characters. Bouly of particularly slender shape, with the tail slender and prolonged, consisting of s segments besides the caudal rami; the last named relatively short. Prehensile antennæ of the male simple, consisting of a thick, cylindrical shaft, and a narrow, claw-shaped, incurved terminal part; the sub-branch very small, nodiform. No frontal appendage present. Branchial feet relatively broad, with the exopodite of rounded oval form and the onter covering plate serrated on the edges. Marsupium of the female particularly narrow and elongated, almost cylindrical.

Remarks. This genus, established by the American naturalist, Prof. Verrill, is chiefly characterised, in contrast with the gen. Branchipus, Schäffer, by the extraordinarily slender shape of the body. 
gelen af Frontalvedhæng hos Hannen, ved den meget forskjellige For'm af Humens Aigbeholder, endelig ved betydelig liortere Halegrene. Betydelig storre Affinitet har den til Slægten Artemia Leach, med hvilken den stemmer overens baade i Henseende til den almindelige Habitus og ved Mangelen af Frontalvedhæug hos Hannen. Den skiller sig inidlertid ogsaa fra denue. Slægt ved visse vel udprægede Characteler, saaledes ved den forskjellige Form af Hannens Gribeantenner og af Hunnens Egbeholder, endelig derved, at Halen har et Segment flere. Man kjender ialt med Sikkerhed 6 herhen horende Arter, nemlig, foruden den nedenfor ncrmere beskrevne arktiske Form, 2 nordamerikanske Arter: $B$. roloradensis Packard og B. Lindahti Packard, en af Baird fra Jerusalem beskreven Form, B. eximia, og to russiske Arter fra Omegnen af Odessa, B. spinosa M. Edw. og B. ferox M. Edw. Det var denne sidste Art, som den russiske Naturforslier Schmankewiteh troede at se forvandlet til en Artemia ved paa kunstig Maade at domesticeres i saltholdigt Vand, noget der vel egentlig er at forstaa saaledes, at Arten under de forandrede Forhold antog risse Characterer, der mindede om ovenuævnte Slægt.

\section{Branchinecta paludosa (Müller).}

\author{
(I'l. VI, VII, VIII).
}

Cancer stagnalis, Fabr, Fanna gronlandica, No. 224 (non Linné). Branchipus paludosus, IIüller, Zool. Danica II, 10, Pl. 48, Fig. 1-8.

Branchipus middcndorfanus, Fischer, Middendorf's Sibirische Reisen, Bd. II, p. 153, Pl. VII, Fig. 17-23.

Branchinecta gronlandica, Verrill, Amer. Journ. Sc. 1869, p. 253. Branchinecta urctica, Idem, ibid.

Artscharacteristik. Legemets Form slank og elegant, med de 3 Kropsafsnit vel markerede. Hovedet af middelmaadig Storrelse, jevnt afiundet fortil hos begge $\mathrm{Kj}$ on. Halen betydelig længere end den foranliggende Del af Legemet, smalt cylindrisk, med næstsiclste Segment det længste, og sidste Segment omtrent halvt saa langt. Halegrenene næsten dobbelt saa lange som sidste Segment. smalt lancetformige og tæt kantede med cilierede Borster. 2det Par Folere hos Hunnen næsten af Hovedets Længde, meget skraat afskaame i Enden, med det bagre Hjorne udtrukket $\mathrm{i}$ en skarp Spids. Samme Folere hos Hannen mere end dobbelt saa lange, Skaftet noget krummet ved Basis, tykt cylindriskt, med en Rad af smaa Tænder langs den indre Kant; Endedelen lidt kortere, noget boiet paa Nidten og jernt afsmalnende mod Spidsen, som er stumpt tilrundet. Branchialfodderne med Endopoditens ydre Lap hos $6-$ G. O. Sars: Fauna Norvegix. by the absence of frontal appendages in the male, by the very different shape of the malsupium of the female, and, finally, by considerably sliorter caudal rami. It has much greater affinity to the genus Artemia, Leach, with which it agrees, both in regard to the general babitus and in the absence of frontal appendages in the male. It distinguishes itself, however, also from that genus by certain well marked characteristics; thus, by the different form of the prehensile antennæ of the male and of the marsupinm in the female, and, finally, in the tail having an additional segment. We know with certainty of 6 species, altogether, pertaining hereto, namely, besides the Arctic form more particularly described below, 2 North American species: B. coloradensis, Packard, and B. Lindahti, Packard; a form from Jerusalem, described by Baird, $B$. eximia; and 2 Russian species from the neighbourhood of Odessa, B. spinosa, M. Edw. and B. ferox M. Edw. It was the last named species that the Russian naturalist Schmankewitch believed to have seen transformed to an Aremia, by being, in an artificial manner, domesticated in water containing salt; a fact which may be more properly understood in this manner, viz. - that the species, under the changed relations, assumed certain characters which reminded of the above-named genus.

\section{Branchinecta paludosa (Miiller).}

\author{
(Pl. VI, VII, VIII).
}

Cancer stagnalis, Fabr., Fauna gronlandica, No. 224 (non Linné). Branchipus paludosus, Müller, Zool. Danica II, 10, I'l. 48, figs $1-8$.

Branchipus middendorfiantes, Fischer, Hiddendorf's Sibirische Reisen, Bd. II, p. 153, Pl. VII, figs. 17-23.

Branchinecta gronlandica, Verrill, Amer. Journ. Sc. 1869, 1, 253. Branchinecta arctica, Idem, ibid.

Specific characteristics. Form of body slendel and elegant, with the 3 body-divisions well malked off. Head of muderate size, evenly rounded in front in both sexes. Tail considerably longer' than the part of the body lying in front of it, narrow cylindrical, with the penultimate segment the longest, and the last segment abont half as long. Candal rami almost twice as long as the last segment, nar'ow lanceolate in shape, and closely edged with ciliated bristles. Second pair of antennæ, in female, almost the length of the head, very obliquely truncated at the extremity, with the posterior corner drawn out to a sharp point. Same antennæ in male more than twice as long; shaft somewhat curved at the base, thick cylindrical, with a series of small teeth along the inner edge; terminal part a little shorter, somewhat curved in the middle, and narrowing evenly towards the point, 
Hunnen kortt triangulæu, hos Hannen betydelig stærhere uddraget og næsten leformig indadkrummet. Hunnens Eghebolder særdeles forlænget, rækkende næsten til Enden af næstsidste Halesegment. Hannens ydre Kjonsvedhæng cylindriske, forsynede ved Basis fortil med 2 fremspringende Flige, mellem hvilke der er en dyb Indbuntning. Legemet hos begge Kijon gjennemsigtigt, med et mere eller mindre tyrleligt gronligt eller rodligt Anstrog. Hnnnens Længde indtil $18 \mathrm{~mm}$., Hannens $23 \mathrm{~mm}$.

Bemærkninger. Denne Art er allerede i 1780 af 0. Fabricius anfort fra Gronland, men urigtigt identificeret med Br. stagnalis Schæffer. Senere er den nnder den oventor anforte Species-Benævnelse kjendeligt beskrevet og afbildet af 0 . Fr. Müller i hans bekjendte Værk, Famna danica. De af Prof. Verrill som B. gronlantica og aretica opforte Former har senere vist sig at rære identiske mod nærrærende Art, og det samme er utvivlsomt ogsaa Tilfældet med $B$. middendorfianus Fischer, Af de 2 nordamerikanske Arter beskrevne af Packard, synes $B$. coloradensis at komme meget nær ten her omhandlede Art, medens $B$. Lindahii skiller sig mere kjendeligt, navnlig ved de betyclelig stærkere forlængede Halegrene.

Generel Beskrivelse. Legemet er hos begge Kijon (se PI. VI, Fig. 1-4) smalt og forlænget, næsten or'mformigt, med særdeles tynde og boielige Integumenter, samt inddelt i tydelige Segmenter. Man lim adskille 3 temmelig sliarpt begrændsede Kropsatsnit, nemlig Hoved, Midtlirop og Bagkrop eller Hale.

Horedet bestaar igjen af 2 Partier, et forreste og et bagerste, skilte rerl en tydelig over Rygsiden gaaende Tværsutur. Ilet forreste Parti er noget opsrnlmet, næsten kugleformigt, og mere eller mindre stærlit nedboiet. Det bærer Ginene og 2 Par Folere, samt fortsætter sig nedentil i Orerlæben. Til det bagre Parti eller. Nakkerlelen horer de orrige IInddele. Af disse er mest ioinefaldende de kraftigt ndriklede Kindbakker, ler som et Par Boiler omgiver Hovedet paa Grændsen mellem dettes 2 Afsnit, og hvis baadformige C'orpora danner til hver' Side et tydeligt convext Fremspring, sely bemarkeligt, nar Dyret sees ovenfra. Lige bag Krindbakkerne sees til hver Side af Nakkesegmentet en S-formigt bugtet Fignr. den saalialdte Skalkjærtel, hris bagre Del omsluttes af en lidt fremspringende Hndfold, den forste svage Antydning til det hos andre Phyllopoder saa stærlit udviklede Rrgskjold eller. Skal. Ventralt udgaar fra Nakliesegmentet de 2 Par Kjæver. which is bluntly rounded. Branchial feet with the onter lobe of the endopodite, in female, short triangular; in male considerably more drawn ont, and almost falciformly curved inwards. Marsupinm of female greatly prolonged, reaching almost to the extremity of the penultimate caudal segment. Outer sexual appendages of male cylindrical, furnished in front, at the base, with 2 projecting flaps, between which there is a deep sinus. Body transparent in both sexes, with a more or less distinct greenish or reddish tinge. Length of female rp) to $18 \mathrm{~m}$. m.; that of male $23 \mathrm{~m} . \mathrm{m}$.

Remarks. This species is, as early as 1780 , recorded by A. Fabricins from Greenland, but erroneously identified with $B$ r. stagnalis, Schæffer. Subsequently it has been, under the above-named specific designation, recognizably described and illustrated by O. Fr. Muller in his well-known work, Fanna danica. The forms established as B. gronlandica and arctica by Prof. Verrill, have subsequently shown themselves to be identical with the present species, and the same is also indubitably the case with B. middentorfianus, Fischer. Of the 2 North American speries described by Packard, B. coloradensis appears to approach pretty closely the species here described, whilst $B$. Linduhli distinguishes itself more noticeably, especially by the considerably more prolonged caudal rami.

General description. The body is, in both sexes, (see Pl. VI, figs. 1-4) narrow and prolonged, almost rermiform, with particularly thin and flexible integuments, and is divided into distinct segments. We can distinguish 3 pretty sharply defined divisions of the body, viz., the cephalon, the mesosome, and the metasome or tail.

The cephalon, again, consists of 2 parts, an anterior and a posterior one, separater by a distinct transversal suture passing across the dorsal side. The foremost part is somewhat swollen, almost globular, and more or less strongly bent downwards. It carries the eyes and the 2 pairs of antennæ, and is continued domnwards in the upper lip. The other oral parts pertain to the posterior, or cervical part. Of these, the most striking are the porrerfully developed mandibles, which like a pair of bows surround the head on the limit between its 2 divisions, and whose cymbiform corpora form on either side a distinctly convex prominence, eren noticeable when the animal is riewed from above. Just behind the mandibles there is seen, on either side of the cervicall segment, an S-formed flexuous fignre, the so-called shell-gland. whose posterior part is enclosed by a slightly projecting integumental folıl, the first faint indication of the, in other Phyllopods so strongly developed carapace or shell. The 2 pairs of 
Det paa Hovelet folgende Kropsafsnit, Midtkroppen eller Truncus, er fortil om trent af Hovedets Brede og lidt nedtrykt, men afsmalnes lidt i sin bagerste Del. Det er sammensat af 11 paa hinanden folgende korte og ensformigt udviklede Segmenter, hroraf ethvert bærer et Par Branchialfodder. Disse sidste folger uned regelmæssige korte Mellemrum efter hinanden, lannende med sine forskjellige Lapper og talrige Borster til hver Side en bred Bræmme. Herved fremkommer langs Midtkroppens Underside en af samtlige Branchialfodder begrændset kanalagtig Fordybuing, der gradvis tiltager noget i Brede fortil, hvor den stoder op mod Mundregionen.

Bagliroppen eller Halen er orerordentlig slank, betydelig smalere end Midtkroppen, og af regelmæssig cylindrisk Form. Den udgior kjendeligt mere end Halvdelen af Legemets Totallængde, og er sammensat af 9 Segmenter fornden Halegrenene. Af disse Segmenter er de '2 forreste kun i den dorsale Del tydeligt sondrede. medens de ventralt gaar over i hinanden og danner her Udspringet for de ydre Kjonsvedhæng. Disse 2 furste Segmenter af Halen vil derfor passende kunne benærnes: Kjonsringene». Hos Hnnnen er rlet forreste af disse Segmenter noget opsrulmet fortil, og det bager'ste damner nedentil, ved Basis af Egbeholderen, 2 rundagtige Fremspring, der navnlig er meget tydeligt fremtrædende, naar Dyret sees ovenfra eller nedenfia (se Tab. VI, Fig. 4, Tab. VIII, Fig. 11). De folgende 5 Segmenter er alle af ens Udseende og ogsaa af tilnærmelsesvis samme Storrelse, simpelt cylindriske, med Længden betydelig storre end Breden. Nrestsidste Segment er derimod betydelig længere end de ovvige, og sidste omvendt meget kort, neppe mere end halvt saa langt som næstsillste. Det er (se Tab. VI, Fig. 10) tvært afkuttet $\mathrm{i}$ Enden og viser i Midten af den bagre Kant en ganske svag Indlougtning. 'Til hver' Side af denne, og adsliilte $\mathrm{i}$ Milten red et storre Mlellemrum, er fæstet de smalt lancetformige Halegrene, der maaske, i Lighed med den saakaldte Furea hos Copepoderne, kan betragtes som fremkomne ved Klov. ningen af et terminalt Segment, men som clog ve] correctest vil kumne beskrives som et Par omformede Lemmer.

Hunnens Længde gaar op til 18 mm. Hannen er i Regelen kjenclelig storre og opmaar ofte en Lrengde af indtil $2: 3 \mathrm{~mm}$. Begge Kjon er desuden let k.jendelige ved den meget forskjellige Uuvikling af 2det Par Folere, samt ved Beskaffenheden af de ydre Kjonsvedhrng. Disse ril passende kume beskrives paa dette Sted. maxillæ issue ventrally from the cervical segment.

The division of the body that succeeds the head, the mesosome or truncus, is about same breadth in front as the head, and a little flattened. but narrows a little in its backmost part. It is composed of 11 short and uniformly developed segments, of which each carries a pair of branchial feet. These last follow after each other at regular short intervals, forming with their varions lobes and numerons bristles a broad fringe on either side. In this way there is produced along the mderside of the mesosome a canalular cavity, bordered by all the branchial feet, which gradually increases somewhat in breadth in front, where it joins $u$ j to the oral region.

The metasome or tail is extraordinarily slen. der, considerably narrower than the mesosome, and of regnlar cylindrical shape. It occupies appreciably, more than half the entire length of the body, and is composed of 9 segments besides the caudal rami. Of these segments, the 2 foremost ones are only distinctly seprarated in the dorsal part, whilst they ventrally pass over into each other, and form liere the origin of the outer sexital appendages. These 2 first segments of the tail may, therefore, suitably be named "the sexual segments». In the female the foremost of these segments is somewhat swollen in front; and the luackmost forms downwards, at the luse of the marsupium, 2 ronndish prominences, which are, especially, very distinctly prominent when the animal is viewed from above or from below (see Pl. VI, fig. 4, Pl. VIII, fig. 11). The succeeding 5 segments lave all a uniform appearance, and are also of approximately the same size, plain cylindrical, with the length considerably greater than the breadth. The penultimate segment is, on the contrary, considerably longer than the others, while, on the other land, the last is very short, scarcely more than lialf as long as the penultimate one. It is (see PI. VI, fig. 10 transrersally truncated at the extremity, and in the middle of the posterior edge shows a quite faint sinus. On either side of this, and seprarated in the middle loy a largish interval, the marrow lanceolate cantal rami are attached, which, perhaps, like the so-called furca in the Copeporls, nay be considered as produced by the splitting of a terminal segment, but which, howerer, probably more correctly may be described as a pair of transformed appendages.

The length of the female reaches up to $18 \mathrm{~m}$. m. The male is, as a rule, appreciably larger, and frequently attains a length of $23 \mathrm{~m}$. m. Both sexes are, further, easily recognizable by the very different derelopment of the 'nd pain of antennæ, and by the character of the onter sexnal appendages. Thest may be conveniently described here. 
Hos Hunnen (Tab. VI, Fig. 3, 4) danner de ydre Kjonsvedhæng en enkelt bagndrettet, poseformig Beholder af meget smal, næsten cylindrisk Form, dog gradvis noget tiltagende i Tykkelse mod Enden. I sin fulde Ulvikling rækker den næsten til Enclen af næstsidste Halesegment; men er ofte en Del kortere. Sxdvanligvis sees $\mathrm{i}$ dens indre et storre eller mindre Antal af $\mathrm{Eg}$ af morkegron Farve, ordnede i 2 eller flere Rader. Enden af Egbeholderen er noget koniskt tillobende og bestaar af 2 ved særegne Vnskler bevægelige Klapper, der begrændser en tværliggende spaltformig Aabning, hvorigjennem Eggene udstodes. Den ventrale Klap er noget mere fremragende end den dorsale og ender med et lidet papilleformigt Fremspring (se Tab. VIII, Fig. 11).

Hos Hannen (Tab. VI, Fig. 1 og 2) er Kjonshængene dobbelte og meget smaa. De udspringer (se Fig. 11) hvert med en temmelig bred Basis fra Siderne af de 2 Kjonsringe og retter sig skraat nedad og bagud. Fortil viser de nær sit Udspring en dybt indstikkende Bugt, som begrændses oventil af en sammentrykt triangulær Lap, nedentil af en konisk tilspidset Fortsats. Den yilre Del af Vedhænget er simpelt cylindriskt, og fra dens stumpt tilrundede Ende sees undertiden en uregelmæssig sagtakket Vorte at skyde frem, egentlig en Udkrængning af vas deferens.

Legemet er hos begge Kjon i hoi Grad gjennemsigtigt, saa at de indre Organer, navnlig den med rodgult Indhold fyldte Tarmlianal, tydeligt skinner igjennem de tynde Integnmenter. Farven er noget velislende efter Lokaliteterne, snart meget bleg, hvidagtig, snart med et mere eller mindre tydeligt rodligt eller grønligt Anstrog.

\section{Beskrivelse af líroppens Vedhaug.}

Dinene (Tab. VI, Fig. 9; Tab. VII, Fig. 1 og $2,0)$, der rager frem til hver side fra den forreste Del af Hovedet, er stilkede og viser idethele en meget lignende Bygning som hos Nebalia, skjondt deres Berægelighed er langt mere begrændset. Af Form er de næsten kolledannede, idet de gradvis udvides mod Enden, der er noget skjævt tilrundet. Den egentlige Øienglob, der indtager omtrent $1 / 3$ af Oiets Længde, indeholder en oval eller elliptisk Ansamling af morkt Pigment, omgivet udad af en klar Zone, hvori de ydre lysbrydende Dele af Synselementerne har sin Plads (se Tab. VIII, Fig. 6). Nogen ydre Facettering er ligesaalidt tilstede her som hos Nebalia. - Midt imellem Dinene sees i det Indre af Hovedet en dyb sort Pigmentplet, som er det saakaldte Ocellns eller enkle Oie.
In the female (Pl. VI, figs. 3,4), the outer sexual appendages form a single, bag-formed reservoir directed backwards, of very narrow, almost cylindrical shape, but increasing gradually somewhat in thickness towards the extremity. In its full development it extends almost to the extremity of the penultimate segment, but is often somewhat shorter. There is usually seen in its interior a larger or smaller number of ova of dark green colour, arranged in 2 or several series. The extremity of the marsupium runs somewhat conically out, and consists of 2 flaps, moveable by means of peculiar muscles, which define a transversal fissure-like aperture through which the ova are expelled. The ventral flap is somewhat more projected than the dorsal one, and terminates in a small papilliform prominence (see Pl. VIII, fig. 11).

In the male (PI. VI, figs. 1 and 2), the sexnal apjendages are deuble and very small. They issue, (see fig. 11), each with a pretty broad base, from the sides of the 2 sexual segments and are directed obliquely downmards and backwards. They exhibit in front, near their origin, a deep sinns, which is defined above by a compressed triangular lobe, and below by a conically pointed projection. The outer part of the appendage is plain cylindrical, and from its blnntly rounded extremity an irregularly serrated nipple is sometimes seen to project, really a lunging out of the vas deferens.

The body, in both sexes, is in a high degree transparent, so that the internal organs, especially the intestinal canal, filled with red-yellow contents, shine distinctly through the thin integuments. The colour is somewhat variable, according to the locality, sometimes very pale, whitish, sometimes with a more or less distinct reddish or greenish tinge.

\section{Description of the appendiges of the borly.}

The eyes (Pl. VI, fig. 9; Pl. VII, figs. 1 and 2,0 ), which project forwards on either sicle of the foremost part of the hearl, are distinctly pedunculated, and altogether exhibit a very similar structure to those of Nebalia, although their mobility is far more limited. They are almost claviform in shape, as they become gradually dilated towards the extremity, which is somewhat obliquely rounded. The real ocular globe, which occupies about $1 / 3$ of the eye, contains an oval or elliptical collection of dark pigment, surrounded outwards by a clear zone in which the onter refracting portions of the visual elements have their position (see Pl. VIII, fig. 6). Any external facetting is just as little present here as in Nebalia. Nidway between the eyes there is seen, in the interior of the head, a deep black pigment-patch, which is the so-called ocellus or simple eye. 
Forste Par Folere (Tab. VI, Fig. 9, a ; Tab. VII, Fig. 1, 2, $\mathrm{a}^{1}$ ) er meget smaa og simpelt byggede, dannende hver en meget smal cylindrisk, eller næsten traadformig Stamme, paa hvilken ingen tydeligt ndpræget Leddeling kan paavises. De er sædvanligvis rettede skraat fortil og udad (se Tab. VI, Fig. 1-4), men kan ogsaa til en vis Grad bevæges $i$ andre Retninger, ligesom de idethele er meget boielige. Paa Spidsen, der er noget skraat afskaaret, bærer de (se Tab. VIII, Fig. ") en Gruppe af 8 yderst smaa og delikate Sandsevedhreng, som ved stærk Forstorrelse (Fig. 3) viser en stavdannet Form, med et kort, dobbelt contureret Fodstykke og en liden klar Blære ved den stumpt afrundede Spids. Ifolge sin Bygning maa disse Vedhæng nærmest betragtes som Lngtepapiller; medens de 3 betydelig længere, og $\mathrm{i}$ en fin Spids udgaaende Vedhæng, som ndspringer i nogen Afstand fra hine fra en afrundet Forhoining, utvivlsomt er at anse som ægte Foleborster.

Andet Par Folere, der ndspringer fra Hovedets nedre Flade umiddelbart nedenfor og lidt indenfor det 1ste Par, er meget forskjellige hos de 2 Kjon. Hos Humnen er de (se Tab. VI, Fig. 9, a ${ }^{2}$; Tab. VII, Fig. $1, a^{2}$ ) forholdsvis smaa og simple, dannende et Par, som det synes fuldkommen ubevægelige fra Hoverlet nedhængende pladeformige Flige. De er ontrent af samme Længde som Oinene og næsten triangulære i Form, idet de udspuringer med en temmelig bred Basis og gradvis afsmalnes mod Enden, som er meget skraat afskaaret, med det bagre Hjorne nddraget $i$ en skarp Spids. I sin forreste Kant har de nogle yderst smaa Foleborster, men er fororrigt ganske ubevæbnede. - Hos Hannen er disse Folere (se Tab. VI, Fig. 1, 2; Tab. VII, Fig. 2, $\mathrm{a}^{2}$ ) langt stærkere udviklede og omformede til kraftige Griberedskaber, hvormed Hunnen fastholdes nnder Copulationen. I Hviletilstand er de mere eller mindre stærkt ombøiede mod Bugsiden og rækker i denne Stilling omtrent til Midten af Forkroppen. Man kau paa dem adskille to skarpt begrændsede Afsuit: et tylit eylindriskt og stærkt muskulost Skaft, og en tynd kloformig Endedel. Skaftet viser ved Basis flere circnlære Indsnøringer, der antyder 3 til 4 nfuldstændigt sondrede Led. Yderdelen af Sliaftet har indad en noget tilskjærpet Kant, forsynet med en Række af smaa Tænder, og ved Enden, indenfor Endedelens Insertion, findes en liden konisk tillobende Knnude, eller rettere Bigren. Endedelen er noget kortere end Skaftet og meget smalere, men af særdeles fast chitinos Consistens. Den er bevægeligt articuleret med Skaftet og mere eller mindre stærkt indboiet, samt gradvis afsmalnende mod Spidsen, som er stumpt tilrundet. I Modsætning til hvad Tilfælde er hos Hunnen, ex disse Følere hos Hanuen
The first pair of antennæ (Pl. VI, fig. 9, $\mathrm{a}^{1} ; \mathrm{Pl}$. VII, figs. $1,2, a^{1}$ ) are very small and simple in structure, each forming a very narrow eylindrical or almost filamentons stem, upon which no distinctly distinguished articulation can be shown. They are usually directed obliquely forwards and outwards (see Pl. VI, fig. 1-4), bnt may also, to a certain extent, be moved in other directions, while they are also, upon the whole, very Hexible. At the tip, which is somewhat obliquely truncated, they carry (see Pl. VIII, fig. 2) a group of 8 extremely small and delicate sensory appendages, which on a powerful magnification (fig. 3) exhibit a rod-like shape, with a short, double-contoured foot-piece, and a small clear vesicle at the blnntly rounded point. From their structure those appendages inust be chiefly considered as olfactory papille, whilst the 3 considerably longer, and to a fine point issuing, appendages, which spring from a rounded prominence at some distance from the former, must indubitably be considered as gennine sensory bristles.

The scecond pair of antennæ, which issue from the lower surface of the head immediately below and a little inside of the 1st pair, are very different in the 2 sexes. In the female they are (see Pl. VI, fig. 9, $\mathrm{a}^{2}$; PI. VII, fig. $1, \mathrm{a}^{2}$ ) relatively small and simple, forming a pair of apparently perfectly immoveable plate-formed flaps hanging from the head. They are of about same length as the eyes, and almost triangular in shape, as they issne with a pretty broad base and gradually diminish in breadtl towards the extremity, which is very obliquely trumcated, with the posterior corner drawn out to a sharp point. On the foremost edge they have a few extremely small sensory bristles, but are otherwise perfectly nuarmed. In the male these antennæ (see Pl. VI, fig. 1, 2, Pl. VII, fig. 2, $\mathrm{a}^{2}$ ) are far stronger developed, and are transformed into powerfnl prehensile organs by which the female is firmly held during copnlation. In a condition of repose they are more or less greatly recurved towards the ventral side, and in that position extend to the middle of the anterior body. We are able to distinguish upon them two sharply defined divisions; a thick cylindrical and strongly musenlous shaft, and a thin claw-shaped terminal part. The shaft exhibits several circular constrictions at the base, which indicate 3 to 4 imperfectly separated joints. The outer part of the shaft has, inwards, a somewhat sharpened edge, furnished with a series of small teetl; and at the extremity, to the inside of the insertion of the terminal part, there is found a small nodule, or more correctly speaking an accessory branch, which runs ont conically. The terminal part is somewhat shorter than the sliaft and much narrower, but of particularly firm chitinons consistency. It is movably 
meget bevægelige og kan tilsammen virlie som et meget kraftigt tangformigt Griberedskab.

Af Munddelene er Overlæben og de 2 Kindbakker let ioinefaldente. Derimod er de 2 Par Kjæver meget vanskeligere at opdage og lacler sig egentlig kun noiere undersoge ved Disseetion.

Overlæben (Tab. VI, Fig. 9, L; Tab. VII, Fig. 1. L; Fig. 3) har Formen af en aflang Lap, der fra Hovedets Ventralside strækker sig bagtil, og sædranligvis fuldstændig dækker over Kindbakkernes Tyggedele (se Tab. VI, Fig. 9). Den viser paa Midten en svag Udvidning og ender med en stump Spills, livis Kianter er fint cilierede. Dens ydre Flade er noget convex, medens den indadvendte Flade er plan eller concav og laadden af fine, tildels grupperis ordnede Haar. Ved Hjælp af tlere stærke Muskler, som fra Hovedet passerer igjemnem dens Indre, lian den snart loftes op fra Kindbakkerne, snart præsses ind mod dem igjen. Ind mder dens Basis ligger (se Tab. VII, Fig. 3) Murdaabningen i Forn af en tværoval Spalte, der bagtil begrændses af en nbetydelig fremspringende, haaret Kant. Nogen egentlig Underlabe er derimod ikke tilstede.

Kindluakkerne (Tab. VI, Fig. 9, II; Tal. VII, Fig. 1, M; Fig. 4) er af meget kraftig Byguing og omslntter som et Par Boiler den nedre Del af Hovedet paa Grændsen mellem dets forreste og bagerste Parti. Det convexe baadformige Corpus, der saagodtsom fuldstrendig udfyldes af de kraftige, indad convergerende Tyggemusliler, ender oventil i en Spids. der er bevægeligt indleddet til Hovedets Integument verl Enclen af den dorsale Sutur, der begrændser Nakkesegmentet fortil. Den ventrale Ende, eller den egentlige Tyggedel, er (se Tab. VII, Fig. 4) stærkt indhoiet og begræudset fra Corpus ved en srag Indknibning eller Hals. Den er stumpt afkuttet i Enden og har en oval Tyggeflade, der ved stærk Forstorrelse (Fig. 5) viser sig fint riflet partværs, med ilen ydre Del af Rifleme noget grovere og besat med Rækker af tret sammentrængte tandformige Fremspring. Af nogen egentlig slijærende Del, er der imidlertid intetsomhelst Spor.

De 2 Par Kjover liommer forst tilsyne, naar man betragter Dyret fra Bugsilen, efter"ut de forreste Branchialforlder el fjernede eller lagte om til Siderne (se Tab. VI, Fig. !), $\mathrm{m}^{3}-\mathrm{m}^{2}$; Tal). VI], Fig. 1, $m^{1}-m^{2}$. De er hegge forholdsvis smaa og af enkel Bygning: - Forste Par (Tab. TII, Fig. (j) bestaar articulated with the shaft and more or less strongly incurved, anil gradnally diminishes in brealth towards the point, which is bluntly rounded. In eontrast to what is the ease in the female, these antenuæ are, in the male, very mobile, and ean aet together as a very powerfnl forceps-formed prehensile apparatus.

Of the oral parts, the upper lip and the 2 mandibles are readily visible. On the other hand, the 2 pairs of maxillæ are much more diftient to discover and can, in reality, only be closely investigated upon clisseetion.

The anterior lip (Pl. VI, fig. 9, L; Pl. VII, figs. 1 , L; fig. 3) has the shape of an ollong lobe, which extends baekwards from the ventral side of the liead, and usually completely cover's over the masticatory parts of the mandibles (see Pl. VI, fig. 9). It exhibits at the middle a faint dilation, and terminates in a blunt point whose edges are finely ciliated. Its outer surface is somewluat convex, while the inwarls turned surfaee is plane or concave, and flutfy with fine hairs arranged partly in gromps. With the aid of several strong muscles whieh from the head pass throngh its inside, it can easily be raised up from the mandibles, and be easily again pressed in torrards them. In below its base lies the oral aperture, in the shape of a transverse-oval fissure, whieh is bordered behind by an incousiderably projectant lirsute edge. Any real posterior lip is, on the contrary, not present.

The mandibles (Pl. TI, fig. ?, II; Pl. VII, fig. 1, II, fig. 4) are of very powerful structure, and enelose, like a pair of bows, the lotrer part of the head at the limit between the anterior and posterior portions. The eonvex eymbiform corpus, wbich is almost completely oecupjed by the powerful, inwards-convergent masticatory muscles, terminates above in a point, which is movably artieulated to the integument of the head, at the extremity of the dorsal suture which limits the cervical segment in front. The rentral extremity, or the real masticatury part, is (see Pl. VII, tig. 4) strongly incurved and defined from the eorpus by a faiut eonstriction or neck. It is bluntly truneated at the extremity, and has an oval masticatory surface which upon powerful magnifieation (tig. 5) shows itself to be finely fluted transversally, with the onter part of the flutings somewlat coarser, and beset with series of closely crowded dentiform projections. Of any real entting part there is, however, no trace.

The 2 pairs of maxille appear first to view when we observe the animal from the ventral' side after the foremost branchial feet have been removed or placed away to the sides (see Pl. VI, fig. " m. ${ }^{1-}$ m.. ${ }^{2}$; Pl. VII, fig. $\left.1 \mathrm{~m}^{1}{ }^{1}-\mathrm{m} .{ }^{2}\right)$. They are both relatively small and of simple structure. - The first 
af en tyk muskules Basaldel og en med denue bevægeligt forbunden og stærkt indboiet Endedel. Denne sidste har Formen af et triangulært Blad, der paa sin frie, lige afskaarne Rand er besat med en Række af stive Borster, tiltagende i Længde indad. Enhver Borste bestaar (Fig. 7) af en noget tykkere Basaldel besat $\mathrm{i}$ den ene Kant med grove Pigge, og en $\mathrm{i}$ en fin Spids ndlobende, og $\mathrm{i}$ begge Kanter tæt cilieret Endedel. - Andet Par Kjæver (Fig. S) er langtfra saa kraftigt ndviklede og synes heller ikke ifolge sin Stilling at kumne spille nogen væsentlig Rolle ved Næringsoptagelsen. De ndspringer (se Fig. 1, $\mathrm{m}^{2}$ ) lidt bag 1ste Par og er, ganske i Modsætning til hine, rettede ndad. Basaldelen har paa den nedre Sile 3 tykke Fjærborster. Endedelen synes kun at være lirlet bevægelig og viser en noget oval Form. Dens udarlvendte Side er tret besat med stive, kort cilierede Borster, der staar i flere Rækker og divergerer til alle Sider. Den forreste Borste er noget grovere end de ovrige og fæstet i nogen Afstand fra disse til et kort Fremspring.

Branchialfodterne (se Tab. VII, Fig. 9-13) er alle udpræget bladformige og af temmelig bred Form, merl den forreste Flade noget hvelvet og den bagerste mere eller mindre concar. Man kan paa dem adskille de samme Hoveddele, som allerede ovenfor er beskrevne paa Branchialfodderme hos Nebalia. Basaldelen eller Stammen ex af aflang Form og næten ens Brede overalt. I dens Indre sees forskjellige hinanden delvis kryilsende Mruskelbundter, der dels tjener til at boie selve Stammen, dels virker paa de forskjellige Vedhæng. Stammens ydre Kant er noget fortykket og viser véd Basis nogle svage Ind- og Udbugtninger som ell Antydning til en Slags ufuldstæendig Leddeling. Dens indre Kant er delt i 5 korte Lappe, de sankaldte Enditer, hvoraf den bagerste, eller overste, el meget bred og langs sin halvmaneformigt buede Rand besat med en tæt Rad af kamformigt ordnede og stærkt krummede Borster, alle fint cilierede og bestaaende af 2 tydelige Led (se Fig. 10). De ovrige Lappre er meget mindre, mæsten af mammilledamet Form, og besat med lignende krummede Borster, samt desfornden foran dem med et Knippe betydelig grovere saadanne. Endopoditen (end), der danner den umiddelbare For'tsættelse af Stammen, el' forholdsvis ganske kort og har Formen af en bred triangulier, noget indadrettet Plade, besat langs I'derkanten med stærke Fjerborster, der ved Spidsen og langs den indre Kant efterhaanden antager Characteren af korte Torne, cilierede kun i den ene Kant. Exopoditen (ex), der er berægeligt articuleret til en særegen Afsats af Stammen ved Yclersiden af Endopoditen, pair (Pl. VII, fig. 6) consist of a thick, músculous basal part, and a strongly incurved terminal part connected movably with it. The last-named has the form of a triangular lamella which, npon its free, straightly truncated margin, is leset with a series of stiff bristles, increasing in length inwards. Each bristle (fig. 7) consists of a somewhat thicker basal part, beset on the one edge with coarse spikes, and a terminal part which runs out in a fine point and is closely ciliated on both edges. - The second pair of maxille (fig. 8) are far from being so powerfully developer, and neither do they, from their position, appear to play any material part in the securing of nourishment. They issue (see fig. $1 \mathrm{~m}^{2}{ }^{2}$ ) a little behind the 1 st pair, and are, quite in contrast to them, directed outwards. The basal part has 3 thick plumose bristles on the lower side. The terminal part appears to be only little mobile, and exhibits a somewhat oval form. Its ontwardly turned side is closely beset with stiff, short ciliated bristles placed in several series, and divergent to all sides. The foremost bristle is somewhat coarser than the other's, and is attached at some distance from them to a short projection.

The branchial feet (see Pl. VII, figs. 9-13) are all prominently foliaceous and of pretty broad form, with the foremost surface somewhat convex, and the backmost one more or less concave. We can distinguish in then the same chief parts as have already been described above concerning the branchial feet of Nebalia. The basal part or stem is of an oblong shape, and almust uniform in breadth throughont. In its interiol may be seen varions bundles of muscles partly traversing each other, which serve partly to bend the stem itself, partly act on the various appendages. The onter edge of the stem is somewhat thickened, and at the base exlibits a few faint in- and out- curvatures, as an indication of a kind of imperfect articulation. Its imer edge is livided into 5 short lubes, the so-called endites, of which the backmost or uppermost one is very broad, and along its semi-lunary arenate margin is beset with a close series of strongly curved bristles arranged like a comb, all tinely ciliated and consisting of 2 distinct joints (see fig. 10). The other lobes are much smaller, almost mammilliform in shape, and beset with similar curved bristles, and besides, in front of them, with a fascicle of considerably coarser setæ. The endopodite (end) which forms the immediate continuation of the stem, is, comparatively, quite short, and has the form of a broad triangular, somewhat incurved plate, beset along the outer edge with strong plumose setre, which at the tip and along the inner edge snccessively assume the character of short spines, ciliated only on the one edge. The exopodite (ex) which is 
har Formen af et ovalt Blad, rundt om besat med en Rad af Fjærborster. I nogen Afstand fra Exopoditen, omtrent red Midten af Stammens Jderkant, er Epipoditen (ep) fæstet. Den repræsenteres af et forholdsvis ikke meget stort, simpelt, aflangt, sækdamet Vedhæng, der er rettet skraat nedad og bagud. I sin tinere Structur skiller den sig noget fra de ovrige Vedhæng, idet den er af mere spongios Beskaffenhed, og antager paa Spiritusexemplarer meget snart et temmelig opakt Udseende. Foruden de nærnte Horeddele, som alle ogsaa er tilstede hos Nebalia, kommer her endnu til et særegent Vedhæng, der er specielt eiendommeligt for Gruppen Anostraca. og som jeg ovenfor har benævat "Dækpladen», for at antyde dets Bestemmelse, der nærmest synes at være den, til en vis Grad at erstatte det manglende Rygskjold ved at dække over Roden af Branchialfodderne. Dette Vedhæng (b) ndgaar ligeledes fra Ydersiden af Stammen, men lige ved dennes Rod, og har Formen af en meget tynd og gjennemsigtig oval Plade, regelmæssigt sagtakket i Kanterne. - Undersoger man noiere de 11 Par Branchialfodder og sammenligner dem med hverandre, vil man finde enkelte mindre Differentser i deres Bygning. Hvad for det forste Storrelsen angaar, saa tiltager de gradvis noget i Længde fra 1ste til omtrent 5te Par, for saa jevnt at aftage i Storrelse bagtil, saa at sidste Par neppe er balvt saa stort som 5te og noget mindre end 1ste. Det forreste Par (Fig. 9) skiller sig fra de folgende ved en noget ringere Udvikling af Exopoditen, medens Endopoditen er forholdsvis stærkere fremspringende, mindre indadrettet, $o g \mathrm{~km}$ forsynet med en enkelt Torn i Inderkanten. Silste Par (Fig. 12) udmærker sig fra de orrige derved, at Epipoditen har antaget Characteren af en tynd Plade, besat i Kanterne med cilierede Borster, og derved at Dækpladen ganske mangler. Endopoditen er paa dette Par meget kort og af afrundet Form, medens Exopoditen er vel udviklet. - Hos Hannen skiller Branchialfodderne (Fig. 13) sig lijendeligt fra samme hos Hnnnen ved Endopoditens betydelig stærkere Udrikling. Den er navnlig paa de midterste Par stærkt fremspringende indad, næsten af ledannet Form, og forsynet med et stort Antal af Randtorner. Rimeligris har denne Modification af Endopoditen hos Hannen et vist Hensyn til Copulationen, idet Branchialfodderne derved delvis kan fungere som et Slags Griberedskaber og derved understotte 2det Par Antenner i deres Function at fast. holde Hunnen under Parringen. movably articulated to a separate ledge of the stem at the outer side of the endopodite, has the form of an oval lamella, beset all round with a row of plumose setæ. At some distance from the exopodite, about in the middle of the outer edge of the stem, the epipodite (ep) is secnred. It is represented by a, comparatively, not very large, simple, oblong resicular appendage, which turns obliquely downwards and backwards. In its microscopical structure it differs somewhat from the other appendages, exhibiting a more spongions character, and in alcoholic specimens it rely soon assumes a rather opaque appearance. Besides the abore named chief parts, which are all also present in Nebalia, another peculiar appendage is here added, which particularly distinguishes the group Anostraca, and which I have named above "the covering plate», in order to indicate its most probable purpose, viz, to replace to a certain extent the alsent carapace in covering over the base of the branchial feet. This appendage (b) issues likewise from the onter side of the stem, but close to the base of the latter, and has the form of a very thin and pellucid plate, regularly serrated on the edges. - On a closer examination and comparison of the 11 pairs of branchial feet, some minor differences in their structure will be found to exist. Firstly, as regards the size, they increase snecessively somewhat in length from the 1st to abont the 5th pair, after which they again gradually decrease in size, in such a manner that the last pair are scarcely half as large as the 5th and also somewhat smaller than the 1st. The foremost pair (fig. 9) differ from the succeeding ones by a somewhat slighter development of the exopodite, whereas the endopodite is comparatively more strongly produced, less incurvate, and only provided with a single spine on the inner elge. The last pair (fig. 12) distinguish themselves from the others by the epipodite having assumed the character of a thin plate edged with ciliated bristles, and by the complete want of any covering plate. The endopodite is, on this pair, very short and of rounded shape, whereas the exopodite is well developed. In the male the branchial feet (fig. 13) distinguish themselves very markedly from the same in the female, by the much stronger development of the endopodite. The latter is, especially on the middle pairs, strongly prodnced inwards, almost falciform in shape. and provided with a great number of marginal spines. In all probability this modification of the endopodite in the male has a certain relation to the act of copulation, since the branchial feet thereby become, to a certain extent, enabled to act as a kind of prehensile organs, thus assisting the "nd pair of antennæ in their function to retain hold of the female during copulation. 


\section{Intre (1)wather.}

Den indre Organisation er lose narrerende For'm iklie saa sardeles vanskelig' at studere, da Nrrets store Gjennemsighighed gion det muligt at ubservere sangodtsom alle indre Organer $\mathrm{i}$ sins situs, uden at nogen Dissection er fornoden. Pa de her givne Habitusfigurer Tab. VI, Fig. 1-4) er de rigtigste indre Organer antydede, satledus som de riser sig ved en srag Forstorrelse. Paa Talb. ViI er afiildet Inetailler af Nerresprstemet, Fordoielses-vstemet og Kjonssystemet $i$ stærkere Forstorrelse.

Fordøielsessystemet. - Tarmtractus bestaar af :3 tydeligt begriendsede Dele, nemlig Spismror, Chylustarm og Endetarm. Spiseroret er meget kort, strerkt muskulost. og stiger lodret op fra Mundaabningen til den forreste, i Hovedet beliggende Del at 'Tamen. Denne sidste Del er noget udvidet og' viser, orerensstemmende med Legemets Kinturer, en svag Krumning, men gaar forovigt umrerkeligt over i den bagenfor liggende Del af Tarmen, uden at rare begrændset fla samme som nogen virkelig Mave. Fortil udsender deme Del til hrer side en afrumlet blindsakformig Udvidning, som leedst sees, naar Legemet betragtes ovenfra ('Tab. VI, Fig. 4). Ved nermere Undersogelser viser enhver af disse ITdidninger sig stærkt foldet se Tab. VIII, Fig. 10 eller ligesom bestaaende af et Antal uregelmæssige secundwre Udposninger, alle indrendigt beklalte med et kjertelagtigt Epithel, der delvis ograa fort. ratter sig ind i selve Tarmen. Der er ingen Triv] 'm, at disse 2 blindsækformige Udvitninger af 'Tarmen er homologe med det hos andre Phythopoder i Hovedet heliggende complicerede kjertelagtige Urgan, man ialmindelighed liar kaldt Leveren, men som los næræærende Gruppe er stærkt reduceret "g saaledte: par en Maade damer Orergangen til de simple blind wek formige Appendices, der forefindes paa samme Plads los visse Cladocerer. Ligeledes ma de oventur heskrevne saakaldte Leversekke hos Trbatia antages at hore ind under same Kategori, skjondt linn et I'al af disse strekker sig ind i selve Hovedet. Tarmen danner forovrigt (se Tals. Vl, Fig. 1-4) et simpelt cylindriskt, med sterke lingmuskler tirspret Ror, der nden nogen Bugtninger strekker sig giennem Tyrets Axe indtil Halens sillste Segment, hvor den forbinder sig merl Endetarmen. Wemne sidste (se Fig. 10), der altsaa kun el indsliranket til sidste Halesegment, er, som det ovrige Tarmrur, forsynet med strerke Ringmuskler og desuden ved straaleformigt til dens (Ivertlarle garende Mnskelfibre tixeret $\mathrm{i}$ sin stilling. Teel Hjally af alle disse Mnskier bliver denne Tel af Tarmtractus meget bevægelig og lian vexuvis strelst indsuores ug mlvides, hvad der har sin Betydning ved Ldtommelsen at bxcrementerne. Medens I vret lever, wherveres pan Tarmmet meget encroislie peristal-

\section{Interual 0rgans}

The internal organisation in the present form is not especially ditficult to sturly, as the animal's great transparency render's it possible to observe almost all the internal organs in situ, without the necessity of dissection. In the habitus figures hert given (Pl. VI. tigs. 1-t), the most important internal organs are slown as they appear under a low power of the micruscope. On I'T. TII, details of the nerrons, the digestive and the sexulal systems ape given, more highly magnified.

Digestive system. - The intestinal tract conn sists of : clearly-defined protions, riz, the wsophagns, the chyle-intestine and the rectum. The wsophagus is rery short and muscular. and ascents vertinally from the mal oritice to the anterior portion of the intestine. which is situated in the lead. This portion is somewlat expanded, and, in agreement with the conton of the body, exhibits a slight curve, pasing then imperceptibly into that part of the intestine lying belind, withont being defined from it as a true stmmash. In front this portion semls out to each side a rounded, wacal dilatation, which is best seen on viewing the body from above (Pl. Yl, fig. 4). Un a closer examination, each of these dilatations proves to be rery much folded (see Pl. VIII. fig. 10), ol to consist, as it were, of a number of irregular secondary lubules, all lined interiorly with a glandular epithelinm which also partly extend into the intestine itself. There is no donbt that these two weal dilatations of the intestine are hom logous with the complicated glandular organ found in the head of other Phrllopoda, which has generally been eallen the liver, but which. in the present group, is very much reduced, thus torming, to some extent, the transition to the simple crom-like appentagres found in the same place in certain Clanoceru. The previonsly-described biliary caea in Nebatia may similarly be supposed to come under the same rategory, although only two of them extend as far as into the heal itself. The rest of the intestine (see PI. YT, figs. 1-t) is in the form of a simple crlindrical tube funished with strong annular mucles, and extending, without any windings, throngh the animal's axis as far as the last segment of the tail, where it mnites with the rectum. This last (see fig. 10), which is thus contined to the lant caudal segment, is, like the rest of the intestinal tube, furnished with strong annular muscles, and is al $\leqslant 0$ fixed in it position by muscle-filues radiating towards the onter surfare. By the airl of these muxcles, this portion of the intestinal reginn becomer very mobile, and cin be altemately contracter and expanded, thus assisting in the eracuation of the excrements. While the animal is alive, very vigorous peristalti" movement, of the intestinal tube may 
tiske Bevægelser; der med stor Regelmæssighed forplantes langs ad dens hele Langde, ialmindeligherl i Retningen bagfra fortil.

Circulationssystemet. - Hjertet lammer se Tab. YT, Fig, 2, 3, $11 \mathrm{c}$ et overordentlig langstrakt, med bestemte Nellemum indsnoret Ror, der strækker sig ventor Tarmen fir Nakkesegmentet og bagtil lige ind i Halens nastsidste S'egment. Tret er ved fine Wnskeltraade trostet ti] Indsiden af livggens Integument, on viser tor hrert Segment et Par venose ipaltaaloninger, hrorigjennem Bloulet "ptages i Hjer. tet. Den samlerle Blormasse, som paa denne Maade tritnger ind i Hjertet, urlstodes rels fra den forreste. dels fra den bageste Ende, og kommer derpaa ind i raglose Hulım mellem de forskjellige organer. skjomlt saaledes et egentligt Karsytem, bestaaende af Arterier ng Tener, ganslie mangler, cirrulerer clog Bloctet med stor Regelmassinherl onking i Legemet, ilet det folger risse bestemte Baner. Blodet er, som sadvanligt, farvelost og indeholder en Mangde smaa, tildels amoboide Blodlegemer, hvis Gang let larler sig forfolge hos det levende Dyr under Mikroskopet. Hjertets Pnlsationer, hvormuler spaltaabningerne afrexlende aalmes og lukkes. el sæurteles livlige, saa det er megret vanskeligt at tallw, hrormange del skel i Winntet

Nervesystemet. - C'entralielone af Nervesystemet bestari, som hos andre ('rustaceer, af et dorsalt Parti, let ovre Sralgganglion eller Hjernegangliet. og at en rentral Del, ten saakaltte Buggangliekjaule, begge forbundne verl en umkring spiseroret lolende rommissur (se Tab. TIII, Fig. 1).

Hjernegangliet (se Fig. 1, 4. 17), der har sin Plark $\mathrm{i}$ den forreste Del af Horedet, lige troran Begrudelsen at 'Tarmen, er af temmelig betrolig storrelse, no bestan af $\cdot$, i Mirlten mod linanden forbundne srmetriske Hajole. (Tentil damner det tler ladpe, rer delvis omfatter Basis af det enkle (lie re Fig. 4), og til hrer vide fortsatter det sig i len magtigt ndriklede Symmerve (o), efterat have ndsendt on trund Nerre til 1ste l'ar Antennel a ") Fit andet Par Ner'vel sees at udgal fia Hjernegangliet lixngere tortil, til hver Side at ret enkle oie. De ender hrer med en lirlen ganglios (1) proulmning umidrlelbart under en liden grubeforming Fordybning i Hoverlats forreste Integument (a), rimeligris srarenkte til de untrent par samme Sted hos Limnetis furekmmende cilierede Gruber, ter ialmindelighed ansees tor at Slags Sandseorgan. Nerverne tor zdet l'ar Fulere $\mathrm{a}^{2}$, ler" hos Hamnene er hetylelig stakle ent hos Hunnerne, ntspringrer tra den forrest Del af Sralgeommissureme. Iisse sidste forhindw, inden de mnfatter siriserset, ved rn tynd Tra urommisul se Fig. 1 og 4), der ligger red Basis at ()rellathen. be observed, these being transmitted with great regnlarity throughont its entire length, generally from behind forwards.

Circulatory system. - The heart (see Pl. TI, figs. 2, 3, 11 c) consists of an exceedingly elongated tulje, constricted at regular inter'vals, and extending above the intestine from the rervical segment backmards into the pennltimate segment of the tail. It is attacherl by tine muscle-fibres to the insicle of the dorsal integument, and exhibits, in each segment. a pair of venous ostia, through which the bloorl is recpived into the heart. The accumulated mass of linom, which thus forces itself into the heart, is expelled partly from the anterior, partly from the posterior end, and then enters the several carities betreen the various organs. Alhongh there is thus a total absfrce of a true vascular system consisting of artelies and reins, ret the blond circnlates with great regularity through the body, following certain fixed courses. The blond is, as usual, colourless. and contains a number of small, partly amubous blond-mpuscles, whose course may be easily traced under the miclosepe. The pulsations of the heart, during which the ostia alternately open and chse. ale exceedingly rapid, so that it is very diffirult to count the number occuring in a minute

Nervous system. - The central portion of the nervons srstem consists, as in other crustaceans, of a dorsal fart, the snpracsophageal w cerebral ganglion, and of a ventral part, the so called ventral ganglion chain, comnected with one another by a commissulp romnd the resophagus (see Pl. TIIl, fig. 1).

The rerebral ganglion see tigs. 1,4 and 17 . whin is situater in the auterior part of the hearl, just in front of the commencement of the intestine, is of considerable size, ancl consists of 2 svmmetrial halves comnected with one another in the middle. Abure, it forms sereral lobes which partially sur. romul the hase of the ocellus (see fig. 1), and, after senling out a fine nerve to each of the tirst frair of antennx $\left(\mathrm{a}^{1}\right)$, continues on each side in the form of the powertully dereloped optic nerve (1). A second pair of nerves are seen to issue from the cerelsral ganglion farther forward, on each sirle of the orellus. Ther each end in a little ganglionic protnberance imniediately lyelow a small pit-like depression in the anterior integument of the head (a) probably answering to the ciliated pits occurring in about the same place in Limmetis, and which are senerally" considererl to loe a lind of organ of sense. The nerves for the second pair of antenne $\left(\mathrm{a}^{2}\right)$ which are consirlerably stronger in the males than in the females, originate from the anterior part of the (psiphageal commissures. These, before they pncirle the (rsplihagus, are comnected by a thin transverse rommissure (see figs. 1 and t) lying neas the base of the anterior lip. 
Buggangliekjæden (se Fig. 1) er ikke vanskelig at observere saavel hos levende Exemplarer som. hos Specimina opbevarede i fortyndet Spiritus. Man behover blot med Forsigtighed at udbrede Branchialforderne til hrer Side ng indstille Mikroskopet skarpt par Bugfladen af Dyret, og demne Del af Nerre systemet vil, ialfald delvis, klart og tydeligt sees, uden at nogen virkelig Dissection er fornoden. Dog er dens forreste Del altid temmelig ranskelig at observere, da den fordetmeste skjules af de lidet giennemsigtige Kindbakker og af Kjæverne. Bugangliekjaden riser en meget ndrraget stigerlannet Form, idet den bestaar af ? vidt adskilte stærke Nervestammer, som i hvert Segment forbindes med en dobbelt Traercomnissur. Paa lette Sted viser hrev Nervestamme en temmelig svag ganglios Opssulmning (se Fig. 5), fra hvis ydre Nide 2 stærke Nerver udspringer. Det ene Par af disse Nerver træenger ind $i$ de respective Branchialfodder, medens det andet Par synes at imervere de Muskler, der fra Kroppen passerer til Basis at disse Lemmer. En anden betydelig svagere Nerve udspringer omtrent fir Widten af enhrer af Længdecommissurcrne og synes at ende i legemets Sidemuskler. Antallet af de Nerreknuder, der sammen ned Commissurerne danner Buggangliekjæden, er paa hrer Side 15 (se Fig. 1). Heraf er de 3 forreste Par bestemte for Kindbakkerne og de 2 Par Kjæver, det bageste Par for Genitalsegmentet, de 11 ovrige for de 11 Par Branchialfodder. Buggangliekjæden er saaledes indskrænket til Forkroppen alene. I Bagkropjen fortsxttes rigtignok de 2 Nervestammer lige til Enden af sidste Segment, men uden her at være forbundne ved Trærcommissurer og nien at dame tylelige Ganglier. I hvert Halesegment ndsender disse Nerve. stammer fine Nervegrene, hroraf nogle synes at ndbrede sig i Halens Muskmlatur, medens andre ender med en liden ganglios Opsrumning lige muder Huden (se Fig: S). Paa disse Steder sees altid en overordentlig fin Borste (Foleborste) at springe frem, tilrels omgiven af smaa Hudpapiller (Fig. 9).

Angaaende den Maade, hrorpa de ovrige Nerver ender, skal her blot omtales Forholdet med de til 1ste Par Folere gaaende Nerren og Śrnsnerverne.

Forste Par Foleres Nerver ndspinger (se Fig. 4) tilsvneladende fra det basale Parti af Synsnerverne, irlet hegge Nerver ved sit Udspring er omgivet af en fælles Nerreskede. De træder derefter til hrer Sirle som en tynd Stammp ind i 1ste Par Foleres Basis og fortsatter sig igjennem deres Axe indtil henimod Spidsen. Her deler Nerven sig (se Fig 2) i 2 Grene, der tilsammen danner en betydelig ganglios Masse red Spidsen af" Foleren. "Fra denne
The ventral ganglion chain (see fig. 1) is not difficult to examine, either in living sperimens or in those preserved in dilnterl spinit. It is only neees. sary to turn the loranchial legs carefully to eithr'l side, and adjust the microscope close to the animal's rentral surface, when this part of the nerrous svitem, will, at any rate to some extent, be seen clearly and distinctly, without the necessity of artual dissection. The front part, however, is alivays rather difficult of observation, as it is generally almost hidden br the but slightly transparent manribles and by the maxillx. The ventral ganglion chain exhibit a marked ladder-like form, in that it consists of 2 strong, widely-separated nerve-stems, which are connected in earh segment by a double transvelse commissme. Here each nerve-stem exhibits a rather slight ganglionic dilatation (see fig. 5), on the onter sicle of which, 2 strong nerves have their migin. One of these pairs of nerres penetrates into the respective branchial legs, while the other pair appears to innerve the muscles passing from the body to the base of those appendages. Another much weaker nerve has its origin almost in the middle of each of the longitudinal commissnres, and appears to end in the lateral muscles of the body. The number of ganglia that, together with the rommissures, form the ventral ganghon chain, is 15 on each side (see fig. 1). Of these the 3 foremost pairs are destined for the mandibles and the two pairs of maxilla, the lindmost pair for the genital segment, and the lemaining 11 for the 11 pairs of branchial legs. The ventral ganglion chain is thus confined to the anterior dirision of the body. It is true that the 2 nerve-stems are continned im the hinder part of the body as fal as the end of the last segment, but without being there comnecter by any transverse commissures, and withont forming distuct ganglia. In every caudal segment these nerve-stems send out delicate rami, some of which appear to spread over the candal musculature, while others end in a little ganglionic tuberosity just below the integriment (see fig. 8.) At these places an exceedingly fine bristle (sensory bristle) is always seen to protrude, partially surounded by small cutaneons papilla (tig. 9).

With regard to the manner in which the remaining nerves end, only the circumstances relating to those of the 1st pair of antennæ, and the optic nerves will be mentioned liere.

The nerves of the 1 st pail of antennæ (see tig. 1 ) apparently originate from the basal part of the optic nerres, both nerres being snrounded at their origin by a common nemal-sheath. They then jass to either side in the form of a thin stem into the base of the first pair of antennæ, whence they con tinue along the axis of the latter almost to the extremity. Here the nerve divides (see fig. 2) into 2 branches, whirh together form a considerable 
gangliose Masie ndgaar jojen overondentlig fine Tervefibre til ethrert af de her fasterle Vealhang:

Simsnervelue Fig. 4, of damel til hvel side en strek, Jige udad ganende ,tamme, der, efterat væu

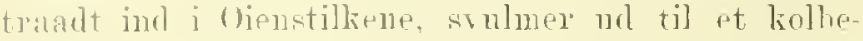
tommigt synsganglion. Thette (se Fig. (i) el red en transtejas] Indenoring delt i 2 pas hinanden folgende Kinder eller Sogmenter og ndsender fia sin noget skjovt afumdode Ende talrige divergerende Nelvetrarle, dey passeler til de enkelte synselementor. Ethrert af disse sidste er (se Fig. 7) isoleret. ved en crlindrisk skede, i hris indle den snakaldte Nirnsstar sees sum en fint trasstribet Axe (o), strakkenrle sig mod Peripherien af (liongloben, hrom den forlinder sig med en liegleformig fastere thel, den saalialdte kirstalliegle (b). Demne er nmgivet at et morkemit Pigment ng emder med et starkt lysbrvalende, lindsefomigt Legeme at ellipsoidisk Frum (a). Den dienglohen omgivende vile Hud (rornea) ej ganslie glat, uden Spor at Faretter.

Kjønssystemet. - Han- og Hun-(1)ganeme forholder sig meget ulige, saarel livad Brgning som

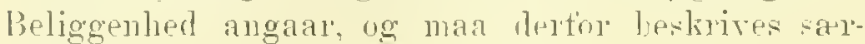
silt.

")arimue se Tab. YT, Fig. "3 ng 4, 'Tah. Vll, Fig. 11 strækkel sig i form at "2 smale "vlindriske rakke igjenuem Stustejarten af 'Truncus. til luver Sirle at og noget nedenumbler Tarmen. Weres forreste Furle ar omtrent heliggembe red hrandsen af trle og 5te forllarende Segment; den hagerste Ende strakker sig ind i selve Kjonsingen. Dermorl findes ingen bel af Grarienne $i$ selve Bagkinjpen, saa-

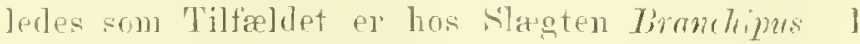
nogen Afistand fin deres hogle Ende ndgaar tia hrert Granim nedad en kort "g trk Aglerler, der ndmumbe i Basis at Eggeralien. Diglederne pr dravis omlyllede at an rolmminos Kiertel, der atsombler ritoffet til Aggeskallen. I Ovarimps Inulp findes som riftest limu en emkelt liakke at" sig udvililenu Eg (se Tah. V11T, fig. 11), med gronagtig

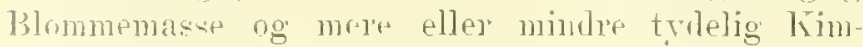
1) lape. Fegene srues at mivikle sig fia den forrestr Encle at Ovarione, da ber findes sammenhoberle pu hel hel smaa celler. Fra Grarierme passere Hggenu, efterluvert som de mudnes, jud i den saktommige Matrix, hrol de omgives merl sin Nial.

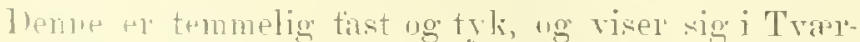
snit tyolfight iloblielt kontureret. Egindlubldet ar i de Heste Tiltakle nuiformt, tintknnet, uden tydelig. Kimblar (Fig. 14). I enkelte Tilfalle (Fig. 1:3) -yntes Klovningsuocusen allerede at vale begrndt,

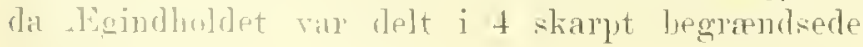
tienminter. ganglionic mass at the end of the antenna. From this ganglionic mass again, exceedingly delicate nerve-fibres mont to eacll of the appenrlages there attarher?.

The nptic nerves (fig. 4, o) form, on each side, a stromg stem going straight ont, which, after haring entered the eye-stalks swells out to a chlo-shaped optic ganglion. This (spe fig. 6), lix a transwerse romstriction, is divided into 2 successive dilatations or segments. and sends ont, from its somenhat ubli yuely rounded end, numerous dirergent nerve-filaments, whirb jass to the several visual elements. Earh of these is isolated lir a cylindrinal sheath (see tig. 7 ) in the interior of which the so-callerl optic lon is visible in the shape of a finely transrelsely striped axis (c) extending tomards the periphery of the eve-ball, where it mites with a firmer, ronical part, the soralled rystalline rone (h) The latter is smromuded by a dark-red jigment, and ends in a strongly refractive lentiform hodr, ellipsoid in shape (a). The skin (comea) surromding the exphall is yuite smooth, witlout a trace of farets.

Generative system. -- The male and female organs are very lissimilar, both as regards stru. tme amr jositim, and must therefore lop separately describur.

The ovalies (see Pl. VI, figs. 3 and 4, Pl. Vlll, fig. 11) extend in the tom of 2 narrum cylindrien] bags through the greater part of the trunk, m each sirle of', and a little below the intestine. Theil' anterion und lies almost at the hom lary hetween the 4th aud bth pedigerous segments; the posterion end extends into the genital segment itself. (In the other hand, no part of the ovaries is toumd in the josterior part of the broly, as is the rase in the genus Branchims. At some distanve from their posterior encls, a short, think oviduct issues tiom pach ovary, passing downwads, and opening into the hase of the ovisar. The ovidurts are partially enveloper by a roluminous gland which serretes the substance for the shlll of the exg. In the inte rior of the ovary thele are fomml, as a rule, rmly a single row of ow in process of development (see P']. VIIT, tig. 11), with a greenisl volk-mass, and more or less distinct gem-resiolss The ora appeal to be dereloped trom the antexior end ot the oraries, as a number of small rells are here found crowderl togethel. Farh egg, as it matules, passes from the ovary into the sar-like marsmpinm, where it is enreloped in its shell. This is tolerably form and thirk, and in transverse sertions slows a distinct double ontline. The montents of the ora are, in most rases, miform, fimely gramular and without distiunt germ-resicles (tig. 14). In one or two cases (tig. 14, the cleavage lrocess seems to have aldeady begum, the contents of the ormm being dividerl intu 4 shanply-rletined segments. 
Testes (Tab. VI, Fig. 11, t) har Fumen at et Par forholdsxis smaa, saliformige Organer, der', nligt lvad Tilfaldet er med Ovariene, iklie strækker sig ind i Forkmpen, idet re fortil knu rakker til Begymdelsen af trueste Kjonsing, hrorimod deres hagre tilspirkerle Furle stratiex sig mere eller mindre ind i lste Bagkropssegment. I nogen Atstand tra den forreste Ende mlgaar nedad og bagtil Facllederen, der liegrnder med et noget blarrormigt udvidet Parti, forestillende et Slags Sredbeholder. Ted Basis at de ydre Kjonsredhrug indsnærres dette Parti pholesligt til en trang Kanal, der giox en stark Bugtning inden den træeler ind i selva kjonsvedlatnget (1), par hvis spids den ndmunder. Sipema bestaar (se Fig. 12) at sman lilare Celler med tydelig Kjeune, imellem hvilke sers en lel endnu mindue og mere ngjennemsigtige Smaakngler.

Udvikling. - . leg har desvaple iklie lave Anledning til at fortolge den hele Udrikling af narvarende Fon, men har dog leilighedsvis paatruffet en Del Udrililingsstarlier, hrorat jeg her liortelig kal omtale nogle.

Wet tidlinste Larvestadinm, jeg lar fundet, el afbildet Tab. TI11, Fig. 15, og maa namest waracteriseres som et Metamanplins-Startim, forsaavilt som dex allerede er trilelige Anlreg til 7 Par Lemmer bag de egentlige IIuddele. I tet agte Nauplinsstadinm er, som bekjendt, ndnirrket verl Tilstedevarelsen at' lim 3 Par Lemmer, nemlig de 2 Par Folere ug Mandibulartodnerne, og i dette Stadinm forlader narrarende Form, som de Heste ovrige Phyllopoder, Aigget.

Legemet er i det leer rmbandlerle Stadinm atlangt pærofrumigt, grarlvis atsmalnende loagtil og stumpt afrumdet fortil, men tyalelig Begrandsning at Hover, Krop og Hale. Te sammensatte oine er

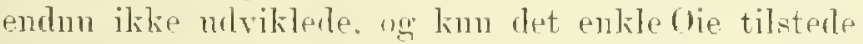
i Midten helt fortil. Lsto Par Folere er endnu ganske korte, men ragrer tydeligt trem fortil ng er zaa spirlsen mlinstede med lignemile Tedliæng som los det voxne byr. Zlet Par Eulere r meget forskje]lige fra samme hos det voxne byx, og udviklede til magtige Srommeorganer ellel darer. De udspringer, noget ventralt, til hver side af den torreste Del af Legemet, lige bag lste Par, "ng er ialminde. lighed rettede lige ndar. Man kan par lem ad skille en tyk og hoielig, med talrige nluskler fyldt Basaldel eller Nkaft, og 2 nlige mikiklede (irens. Skaftet el af "rlinhisk Form og viser flex circulape Indsnoringer som en Antrolning til Leddeling let mdsender indad 2 mod Mnmdaalmingen retterle Fortsatser, hvorat den ydre, der udspringer nex Enden af Skattet, har Furmen at en gror, jigturnig Borst", "ilieret $i$ sin ydre Del, medens den indre or klovet i Enden til 2 cilierede Borster. Turler Aarexnes Tievagelser hliver disse Fortartser afrexlemde
The testes [P. VI, fig. 11, t; al in the form ot a pair ot comparatively small hag-like organs which, mulike the ovaries, do not extend into the anterior division of the bodr, but unly as far for wayd as the beginning of the foremost genital segment Their posterior yointed ench, on the other lamil extend more or less into the lst segment of the tail At some distanos firm the anterior end issues, in an downward and backward lirection, the suermati. duet, leginning with a bladder-like pularged portion, representing a kind of seminal resirle. At the base of the extemal sexnal appeniage, this part suddenly contrarts to a narrow "hammel, whirh makes a sharp cmove before it artually enters the sexual appendage $p$ ) at the point of which it discharges itselt, The slerm (see tig. 12) consists of small, clear rells with distiuct nuclei, among which there are a tew still smaller and more opraque spherules.

Development. - l have mutiotumately had no opportmity of following the whole romses of development of the present form, lut have, however, occasionally come aeross certain stages of development, some of which 1 will now briefly mention.

'Th" earliest larval stage that 1 have tomm is representerl on Pl. YTII, fig. 15, and may lie hest aharacterized as a metamamplius stadium, in as much as there are clistinnt indiuations of 7 pairs of limbs behind the oral region proper. "The true uauplins stadium, as is well known, is distinguished by the presence of mly 3 yairs of limbs, namely, the 2 pairs of antenna and the mandibnlar legs, and at this stage, the juesent form, like most other Phrollopoda, leaves the ergn.

In the stage nuw nuder "onsidenation, the hory is of)long, Jyiform, gradnally narrowing posteriorly and bhutly rombled anterionly, withont any distinct division into head. borly aml tail. The mmpomd eyes are not yet developed, and only the orellus is present in the midlle in firnt. The first pair of antenna are as yet quite short, but distinctly projert in front, and are anmed at the point with appentages similar tw those in the tirll-grown animal. The second yair of antemit are very different from that pair in the fullgrown animal, and have the rharactex of yowerful matatory mgans, or was. They have their origin a little ventrally at earh side of the anteriur jart of the body, just behind the tirst pair, and generally point straight ont. A thick, Hexible basal part ir sadpe, hilled with mmelons muscles mat he distinsuished, and 2 unequally developed rami. The supe is relindrioal in form. and exhibits several circular constrictions as an indiontion of articulation. It sends ont inwards, towards the oral apertme, ? projertions of which the onter one, which spuings fiom near the end of the scape, has the form of a coarse spike-like bristle, riliated on the unter part; while the imer one is aloven at the end into "2 ciliated 
fjernet og næmet til Mundaabningen og bidrager dersed til Fodens Optagelse. Af de 2 Grene er den indre ganske kort, cylindrisk og forsynet paa spidren med 4 cilierede Borster. Den rdre Gren er derinod af betrdelig Storrelse, omtrent saa lang som Skaftet ug temmelig trk, dog gradvis af:malnende mod Enden. Den er meget boielig og viser en Antrdning til en tet Leddeling, idet Kanterne er fint r.pennlerede. Langs ad dens indre side findes en Tard af 15-16 stærke, cilierede Svommeborster, hvoraf 2 ndgar fra selve Spirdsen. - Overlæben er meget stor og fremspringende, dannende en oral, i en stump Spids endende og i Flugt med Hovedets mulre Flade gaaende Klap, ler ganske dækker Nundaabningen nedarl. - Kindbakkerne er synlige til hrer Side af Overlæben som 2 convexe Fremspring; men deres Tygrealele sprnes endmu ikke at vere ndviklet. Derimod har enhrer Kindbakke paa den rdre Side et temmelig stort fodformigt Vedhæng af aflang oral Form og forsmet med ialt 8 cilierede Borster, hvoraf 3 migaar fra Spidsen, 3 fra en bred Iap af den loagre Rand og 2 fra en noget mindre Lap mellem deme og Spidsen. To Par smaa knudeformige Fremspring nmiddellart loag Kindbakkerne antyder Anlægget til de 2 Par Kjærer. Af Branchialfouder er der Anleg til 7 Par, successirt aftagende i Storrelse bagtil. De har alle Formen af simple Trarvister, nden Spor af Borster. Haleenden gaar nd i 2 smaa tilspirlsede Lappe, enhrer endende med en enkelt liden simpel Borste. I det indre af Legemet sees tyrleligt den med orangefarret Indhold fyllte Tarmkanal, der fortil danner to simple tilrundede Blindsække. Larven berreger sig meget raskt om i Vandet ver rythmiske Slag af 2det Par Folere, som i dette Stadim er dens eneste Lokomotionsorganer.

Dot Fig. 16 afbildede Larvestadinm er allerede adskilligt videre udviliet. Legemet er strerkere forlænget og viser en logyndende Sondring $\mathbf{i}$ de $\mathbf{3}$ Kropisafsnit. Hovedet er dog entun meget kort og næsten træert afkuttet fortil. De sammensatte Oine har $n u$ begrndt at udvikle sig som to eonvexe Fremspring red Basis af 1ste Par Folere. I deres indre er der afsat en ringe II iengde rodt Pigment, og der er en srag Antyduing til Synselementer. The 2 Par Folere og Munddelene forhwhler sig i alt væsentligt som how det foregaaende Stadium. Derimod er der indtraadt en kjendelig Udvikling af de bag Munddelene folgende Lemmer. De $\mathrm{i}$ forrige Stadimm forekommende 7 Par simple Trapulster, der repræsenterede Anlægget til Branchialfolderne, har nu fordetmeste roudret sig tra Kropssiderne og rager tydeligt frem i Form at huede llarter, der er sragt ind- bristles. Touring the morements of the oars, these projertions are alternately bronght near to and withdratrn from the oral aperture thereby assisting in the admission of food. The inner of the two rami is quite short, cylindrical, and furnished at the point with 4 ciliated bristles. The onter ramns, on the other hand, is of considerable size, ahout as long as the seape, and tolerably thick, though tapering towards the extremity. It is very flexible. and shows an indication of close articnlation, the margins being finely cremulated. Along its inner side, there is a row of 15 or 16 strong, eiliated, natatory histles. two of which issue from the very point. The labrum is very large and prominent. forming an oval, blunt-pointer flap extending backwards as an immediate continuation of the inferior surface of the head, and quite coreling the oral aperture behw. The mandibles are risible on each side of the labrum in the form of 2 convex projections, lont their masticatory part appears to be still undereloped. Each mandible has, however, on the onter side, a rather large, oblong oval leg-like alpendage furnisherl with \& eiliated hristles, 3 of whinh issne from the point, 3 from a broad lobe of the hind margin, and 2 from a somewhat smaller lobe between the hind margin and the point. Twr pairs of small knob-like projections immediately behind the mantibles indicate the 2 incipient pairs of maxillæ. There are indications of 6 prairs of branchial legs, sncressively decreasing in ize posterimly. They all have the form of simple transverse prominences withont a trace of bristles. The ent of the tail divides into 2 small pointed lohes, each terminating in a single, small, simple liristle. Within the body may be plainly seen the intestinal canal with its orange-coloured contents, forming in front 2 simple, ronnded cæca. The larra moves abont rapidly in the water with rythical strokes of the second pair of antemne, which, in this stage, are its only organs of locomotion.

The larval stage represented in fig. 16 is already considerably more developed. The body is more elongated, and shows an incipient division into the 3 sections of the body. The head is still, however, very short and almost abruptly cut off in front. The compound eyes have now begun to develop in the form of 2 convex projections at the base of the first pair of antennæ. Inside them there is a small rnantity uf red pigment, and there is a faint indicatim of visual elements. The two prairs of antennæ and the oral parts are essentially in the same condition as in the foregoing stadimm. On the other hand there is a perceptible derelopment of the limbs belind the oral parts. The 7 pairs of simple transrerse prominences in the previons stadium, whirh represented the incipient hranmial legs, have now for the mont part separated themselves from the 
skanme i Kanterne og delvis forsyede med korte Borster. Bag disse 7 Par Lemmer sees endnu 2 Par smaa "Trarvulster", hrorved disse Lemmers Antal ex steget til 9 Par. Endmn mangler imidlertid ethrert spor til de 2 sidste Par, som forst senere anlregges paa samme Maade som de orrige. Bagkroppen er endnu ganske kort og nledulet. Lens Endelapper har sondret sig fra Haleenden og harer nu hver 3 borsteformige Vedhæug, hrorat det midterste ar betrilelig storie end de ") ovige.

Fig. 17 tremstiller den forreste 1)el at Legemet hos et lidt senere Larvestarium, seet nedenfia og noget striere forstoriet. De sammensatte Gine (o) har tiltaget betydelig i Storelse og viser sig allerede kort stilkede, med Oiengluben vel udviklet. 1ste Par Folere $\left(a^{1}\right)$ er paa det nærmeste utoranlrerle. zdet Par Folere $\left(\mathrm{a}^{2}\right)$ synes forholdsvis minhre, idet de el bleven staaendr paa samme Udviklingstrin, medens de Heste ovige Tle el tiltaget i Storrelse. Det samme gjalder ogsaa Mándibularfodderne (p), som i Forhold til selve Kindbakkerues Corpus (II) synes meget reducerede. Overlathen (L) er fremdeles meget stox og fremragende. De 2 Par Kjæver er allerede tydeligt ndviklede og forsynede med en Del Borster. Alle Branchialfoulder er nu anlagte, men de 2 bagerste Par endun kun tilstede som ubetylelige Trærvulster.

Ender den videve Udvikling sondrev Anlagget til d*2 bagerste Par Branchialfodder sig fra Kropssiderne som tydeligt fremragende Lemmer, Halen strækker sig i Langden og bliver, som det ovige Legeme, tyrleligt segmenteret, samtidigt ned at Halepladerne mere tydeligt afgræudser sig og laar et storre Antal Borster. odet Par Folere reduceres mere og mere, men beholder dog endnu en Tid lang sine Srommelmoster og berages som hos de yngre larver. Nandibularfodderne svinder mpre og mer ind og er tjlsidst kmm tilstede som rulimentare Verllixng. Larven, som paa dette Stadium har en Langde af omtrent $\bar{n}$ mm, staal nu paa Orergangen til at antage den l, livende Tilstand. Den er atbildet paa dette Udviklingstrin 'Tab. VI, Fig. o og 6 . Ted den dexpaa tolgende Hndskiftning er Larvetilstanden turb, idet det sidste Sprer af Mandibularfolderne er. forstumdet og ?det Par Folere liar taht sin Betydning af Lukmmotionsorganer. Endmu er der dog paa le sidstnurnte Lemmer (se Fig. 7 og 8) en tydelig Adskillelse mellem skaft og trene. Thu ylue Gren uncer i en noget bugtet Sipids, paa livilken endnu de sidste svage Rester af de oprindelige Srommeborster sees (Fig. S); Indergrenen ser nil som et yderst lidet linudeformigt Fremspring, uden enhrer Borstebeliadning. Ev Ungen lestemt til at blive sides of the horly, and project rerceptibly in the form of curved lamellae, slightly indented and with the edges partially furnished with Jristles. Behind these 7 pairs of limbs, 2 more pairs of small transverse prominences are visible, raising their number to a pairs. All trace, however, of the last 2 pairs is still absent, and it is only later that they "ommence in the same rray as the others. The hind prart of the body is still quite short and inarticulated. Its terminal lohes have become separated from the raudal end, and now each eary 3 setifom appendages, the middle on of which is considerably larger than the other two.

Fig. 17 represents the anterior part of the borly in a somewhat more adranced larval stage, seen from below, and rather strongly magnified. The compound eyes (o) have increased considerably in size, and already have short pednneles, while the eye-ball is well-developed. The 1st pair of antennæ $\left(\mathrm{a}^{3}\right)$ are nearly molhanged. The $2 \mathrm{nd}$ pair of antemnat (a $\left.{ }^{2}\right)$ seem to be comparatively smaller, having re mained at the same developmental stage, while most. of the other parts have increased in size. The same. applies to the mandibular legs (p), which, in relation to the borly of the mandible (M), seem very murh relnced in size. 'Tlue lalnum (L) is still very large and projecting: 'The two pairs of maxillæ are alreary perceptibly developed, and funished with a few bristles. All the branchial legs bave now appeared, but the himhosi 2 pairs still only as insig. nificant transverse prominences.

During further development the rumiments of the hindmost 2 pairs of hranchial legs separate themselves from the silles of the body as distinctly projecting limbs. The tail is elongated and lecomes. like the rest wi the body, perceptibly articulated, while, at the same time, the raudal lamellae are more distinctly defined, and have arpuired a larger number of bristles. The second pair of antenna become more and more reducesl, but still tor some time retain their natatory bristles, and are mover as in the yonnger larvas. 'The mantibular legs lwindle more and more, and at last only appear as rndimentary appendages. The larva, which, at this stage, has a length of about $5 \mathrm{~mm}$, is on the point of entering its permanent eondition. It is thus represented on Pl. VI, figs. 5 and 6. With the ensuing exuriation, the laxval perind is past, the last trace of mandibular legs laving vanished, and the and pair of antenux having lost their importance as organs of locomotion. In the last-named limbs (see figs. 7 and 8 ) there is still, however, a distinct separation between the scape and the rami. The outer ramus ends in a somewhat curved point, npon which the last feeble remains of the original natatory bristles are visible (tig. 8). The inner ramus looks like an extremely small noliform projection, 
af Hunkjon, skes der 'n end volerligere Rednktion af disse Folere, hrorred le antager det for Humen harateristiske Trseende af 2 simple triangulære Flige. Hos Hamen mutormes Ydergrenen til rribekloen, og Inderguenen persisterer som let lille knmcletormige Eremsping red Enden af Baraldelen, indendentor Kiloens Lidspring.

\section{Foleliomst og Leveris}

Narverende Plurllupde synes at forekomme menet almindelig, i Mt-Finmarken, hvor jeg har taget den pa flere Steder i stor Mrengde; saaledes i et lidet grumlt Tjern red Mehavm, lıvor den fandtes sammen med Polyartmia forrimata, i et lignende Tijern ved Tardo, og i Here smatjern og grmude Damme pa Fastamlet ()st af Tardo. At Prof. Lilljeburg er den desuden taget red Nordkaj. I Test-Finmarken har jeg derimod ikke observeret den, ligesaalidt sum nogetsteds i Norlland. Mrerkeligt nok optrader den igjen langt sylligere i Lan ret, nemlig par Hovres Hoideplatean, hvor jeg hav taget den meget alminlelig i grunde Damme saavel red Kongsrold som red Terkiu. Denme isolerede Forekomst saa langt tiyd paa kan kun forktares

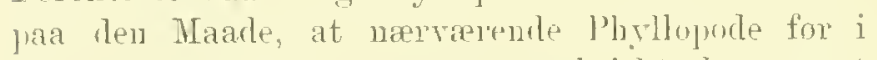
Tiden, da Klimatet var mere arktiskt, hav veret ndbrent wel hele rort Land, ogsaa i Lavlandet, men derpas. efterhrert som Klinatet forandrede sig, liar trukket sig tilbage nomdpaa og tillige til Hoideplatearerne, hvor de klimatiske Fortuold mere lig nede rle oprindelige; merl andre ord: den er her syd i Landet at betragte som en saakaldt relict: Form, en Lerning fra den arktiske Fama, der for i Tiden rir mblodt wrel rout hele Lamb.

Da de Smatjern og Damme, hvori den lever. jegolmaessigt ndtores mod Slutningen af Sommerem, ug vesentlig lim skrlder sin Tilbliven s'ne-meltningen par Forsmmeren, er deme frorms levetid lim iudskrenket til nogle faa Haanedre af taret. I bobet af torhohlsvis kort Tid har den imillertirl gajennemgaat sin Ldrikling, og derofter gaar Forluantningen hurtigt tur sig. Te i Egsckken indeholdte itig, bliver, som anfurt, altid ongirne men en meget trk Shal og r a r benbart alle beregnede paa at creprintre, for til den folgende sommer at molrikls in til m ny Gieneratim. Arten er saaledes for hrert Aar kun leprasinteret rol en enkelt Generation. Engene afinttes i Mndret paa Bunden

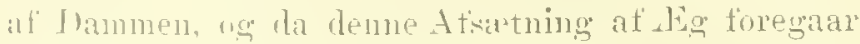
wijntawne trange af lovert Hunindivil, vil der suat

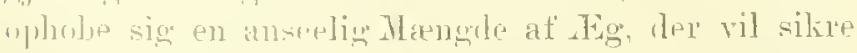

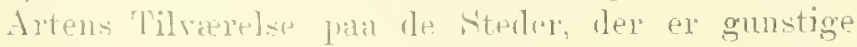
tor danc Trivel. llet el forst ved Midsommertid, with no hristles whatever. If the young one is destined to be of the female sex, a still further re. duction of these antenna takes place, whereby they assume the appearance, characteristir of the females. of 2 simple triangular flaps. In the male the onter ramus is transformed into a prehensile rlaw, while the imel ramus becomes the imall nodiform projection at the end of the basal part, insicle the rnot of the rlaw.

\section{Occurence and Habits.}

The present Phyllojod seems to nour very generally in last. Finmark, where I have fromd it in many places in great numbers, for instance, in a little, shallow lake at Mthavn, where it was found trogether with Polyartomia forciuretr: in a similar lake at Tardo, and in several small lakes and shallow ponds on the mainland east of Tardo. It has also been found by Prof. Lilljeborg at the North Cape. In Wrest Fimmark, on the other hand, I have not observed it, nn ret anywhere in Norlland. C'unious enough, it appears again much farther sonth, namely on the high platean of the Dorve Monutains, where I found it rery plentiful in shallow ponds both at Kongsvold and Jerkin. This isolated nocurence so far south ran only be arcounter for loy the supposition that formerly, when the alimate was more arctic, this Phyllopod was distributed "rer the whole of our land (Now way, lowlands as well as highlands, but that, as the r.limate changed, they have withdrawn to the north and the high plateans, where the rlimatio condition. more resemble those originally prevailing; in other worls, here in the soutl of the country, it must be regarded as a so-called relict» form, a restige of the arctir fanna which was formerly distributed over the whole cumntrs.

As the small lakes and ponds in which it lives dry up periodically towards the end of the smmmer, and owe their existence wiefly to the melting of the suow in the spring, the lite-time of this form is limited to only a few months of the year. In the comse of a comparatively short time, however, it has passerl throngh its developmental rourst. and propangtion then proceeds rapilly. As alrearly stated, the eggs in the wrisac always hecome surrounded hy a rery thick sholl, and are evidently calculated to stand the winter, and in the ensuing smmer to develop into a new generation. The species is thu rpmesented every rear only br a single genpration. The eggs ane deposited in the mud at the bottom of the pond, and as this deposition of eggs is repeaterl several times hy each fomale, a comsiderable number of ergs is soon amassed, which ensmres the existencos of the speries in those places that ale favorable to its well-being. It is not nutil Mirlsummer 
eller j Inli Maaned, at man bos os ialmiudelighed finder denne Form fuldt udviklet. Jeg har paa demne Tid observeret den $i$ strre Hangler $\mathrm{i}$ simatjern pai Dovres Hoideplatean, Ost at Jerkin. Sum Tilfældet synes at vare med de fleste Phyllopoder, naar den temmelig tidligt, og længe for den er fuldt udvoxet, lijonsmodenhert. De storste Individer finder man derfor ialmindelighed langere ud paa $\mathrm{Ho}_{0}$ sten, medens Storrelsen forst pa Sommeren er betydelig ringere. Ofte er der ogsaa paa samme Tid adskillig Forskjel i Storrelsen i forskjellige nærliggende Tjern. I samme Tjern finder man derimod i Regelen alle Individer omtrent ens udviklede og' af ens Farve.

Det ex et meget livligt Dyr, som er i nafbrudt Bevrgelse, oftest mere eller mindre nær Overfladen af Vandet. Bevegelsen tilveielringes hovedsageligt ved Branchialfoddernes Siringninger, der foregaar paa en meget regelmæssig ng elegant Maade, idet de ikke sker noiagtig santidigt for alle Fodders Verlkommende men suressivt, hvad dex giver Indtrykket af en eindommelig Undulatim i Bevægelsen. Jen herved frembragte Loliomution er en ganske jevin i horizontal hetning, hromder Dyret altid render Ryggen nerlad. Dog kan det foretage mange forskjellige Volter i Vandet "g dreie og sno sig i alle Retninger, hrorved Halens Bevægelser spiller en rasentlig Rolle. Hanner og Hunner sees ofte $\mathrm{i}$ Kopulation. idet Hammen med sine Gribeantenner fast omslntter Hunnens Genitalsegment fra Ryggen af, og saaledes kan liegrge Individer sromme om i lange Tider, begge rendende Bugsiden opad. Selve Kivpulationsakten har jeg ikke faaet observeret. Rimeligvis afventer Hannen det Oieblik, da de modne Eg fra Ovarierne træeder ind Bi Basis af Rugesækken, livor de, som orenfor anfort, ongives af sin skal.

Drrets Fode symes hovedsageligt at bestaa af mikroskopiske Alger on andre Plantedele, tildels vel ogsaa af Infusorier, der red Branchialfordernes Spil hrirrles ind mod Munden.

Udbredning. - Narværende Phyllopode er forst beskrevet fra Gronland, hvor den synes at være meget almindolig, og er senere bleven gjenfunden paa Here andre Steder, saaledes det arlitiske Amerika, paa Spitsbergen, Novaja Semlja, Kolahalvoen og $\mathrm{i}$ Sibirien. Idethele falder dens Udbredning, naar nudtages det orennernte Findested i Norge paa Dovres Hoideplatean, ndelukkende indenfor den arktiske Zone, og dens Forekomst her synes at stemple. den som en regte arktisk og eircumpolar Frim. or July that this form is generally found fully developer here. At that season I have olsserved it in great numbers in small lakes on the high platean of the Dorre Mountains, east of Jerkin. As seems to be the ase with most Phyllopork, it attains sexual matnity tolerably early, and long before it is fully grown. The largest specimens are therefore generally found later in the antumn, while the size in the beginning of the summer is very mnch smaller. There is alsn often considerable difference in their size in different lakes, while on the other hand, all the animals in one lake are, as a rule, uniformly developed, and uniform in colonr.

It is a very lively animal, and in constant motion, generally more a less near the surface of the water. The movement is chiefly lnonglit about by the ribrations of the hranehial legs, which take place in a very regnlar and graceful mamer, not quite simultaneously with all the legs, but sucessirely, thereby imparting to the movement a peculi arly undulatory effect. The motion thus produced is equable and in a horizontal direstion, the backi of the animal being always tumed downwards. It may, howerer, make all linds of springs in the water, turning and twisting in every lirertion, the movements "f the tail playing an imprutant part in these evolutions. Males and temales are often seen in copulation, the male, with lis prehensile antennæ, firmly embracing the female's genital segment from the back, and in this manner both animals may swim abont tor a long time with the rentral side nppermost. The act of copnlation itself, I lave not witnessed. The male probalily awaits the moment when the mature ova enter from the orary into the hase of the marsupium, where, as previously stated, they are enreloped in their shell.

The food of this animal seems to consist principally of mieroscopic algee and portions of other plants, partly also of infinsoria, which are swept in towards the mouth by the morement of the branehial legs.

Distribution. - The present Plyyllopod was first deseribed from Greenland, where it seems to be very eommon, and has since heen tound in several other places, e. g. arctic America, spitzbergen, Novaia \%emlia, the Kola Peninsula and in Siberia. Altogether its distrilution, with the exception of the abore-named plare in Norway, on the high platean of the Dorre Monntains, is exclnsively within the arctic zone, and its ocmurence there seems to stamp it as a true aretic and cirenmpolar form. 


\section{Fam. 2. Polyartemiidæ.}

Legemet slankt, med Halen liurt og ufuldkomment segmenteret hos Humen. Gribeantennerne hos Hammen nleddede, og delte i flere hageformigt krummede Grene; Frontalvedhreng tilstede. 19 Par Branchialfodder, alle, mdtagen sidste Par, merl dobdelt Basalplade. Humnens Egheholder kort og tyk, ikke poseformigt fremragende bagtil. Hannens ydre Kjonsvedhæng dobbelte. Halegrenene korte, bladformige, liantede med cilierede Borster.

Bemærkninger. - Af denne Familie kjendes hidtil kum en enkelts slagt, Polyartemia, med en en. kelt Art. Hrad der hovedsageligt skiller denne Familie fra den foregaaende, er det betydelig storre Antal Segmenter i Forkroppen og det deraf folgende furogede Antal Branchialfudder; tremdeles Halens Structur og Egbeholderens Form hos Humen; endelig Gribeantennernes eiendommelige Bygning hos Hammen.

Gen. Polyartemia, Fischer, 1851.

Slægtscharacter. - Legemet næsten "ylindriskt ug meget boieligt. Tijonsrimgene hos Hunnen sammenvoxne med Halen; demne sidste hos Humen med kun et enkelt terminalt Sogment, lus Hammen tydeligt b-lesklet Halegrenene fumollsvis korte. Hannens Gribeantenner B̈-lelte, den forreste Gren storst; Frontalvedhængene simpelt "ylindriske. Branehialfouderne forholdsris brede ug af samme Udseende hos de 2 Rjom, Exopuditen forhohlsvis liden, oval, den ydre lap af Endopoditen stumpt afrundet i Enrlen, begge Basalplarler lielranderle. Hunmens Fgheholier strert ophlest fortil.

Bemærkninger. - Nærværende Slæmt er opstillet i Aaret 1851 at Fisclier og vesentlig characteriseret red det nalmindelig store Antal Branchialtumlisp. Da demue slæat $i$ saa Henseende skiller sig fira alle andre Branchipodider, hos livem Tallet 11 r fuldkommen crustant, fortjener den ntvivlsomt at (ojstilles som Typen for en egen Familie. Slargten incleholder for Tirlen kun en enkelt Art, som nedenfor narmere skal leskrives.

\section{Fam. 2. Polyartemiidæ.}

Body slender, with a short and imperfectly segmented tail in the female. Prehensile antennæ in male inarticulate and divided into several clawlike rami: frontal appendages present. Nineteen pairs of branchial legs, all, except the last pair, with double lrasal laminæ. Marsupium of female short and thick, not projecting posteriorly like a bag. External sexnal appendage of male donble. Candal rami short and laminar, edged with ciliated bristles.

Remarks. - Only one gemus of this family is known np to the present, Polyartemia, with a single speries. What rhiefly distinguishes this fumily from the preceding one is the murh larger number of segments in the anterior part of the bodr, and the consernent angmenter number of branchial legs: furthermore, the strueture of the tail, and the shape of the marsupium in the female, and lastly, the pernliar formation of the prehensile antenna in the male.

\section{Gèn. Polyartemia, Fischer. 1851.}

Generic characters. - Body almost "ylindrical and rery Hexible. Genital segments in temale roalesced witl the tail; the latter, in the female, with a single terminal segment only, in the male distinctly 6-articulate. Candal rami comparatively short. Prehensile antemne of male divider into three curved rami, the foremost leing the largest; trontal appendages of a simple cylindrical shape. Branchial legs romparatively broad, and of a similar appearance in the two sexes; exopodite oval and comparatively small; external lobe of the endopodite bluntly rounded at the ent: buth hasal lamine plain. Marsupium of the female very mueh inflated in front.

Remarks. - The present genus was establisherl in $1851 \mathrm{by}$ Fischer, and is chiefly charasterizer by the nunnally large number of liranchial legs. As it liffers in this respect from all other Branchipodida. where the number 11 is suite invariable, it without douht merits heing estallished as the type of a senarate family. The gemus contains at present only a single speries, which will be more fully describerl below. 


\section{Polyartemia forcipata, Fischer.}

(PI. IX \& X).

Polyartemia forcipata, Fischer, Middendorff's Sibirische Reise, Bd. 2. Zoologie, p. 154, Tab. VII, Fig, 24-2S.

Artscharacter. - Legemet smalt cylindriskt, nasten jevnt tykt hos Humen, nuget afsmalnende bagtil hos Hannen. Hoverlet hos Humnen forholdsvis lidet og afrumdet fortil, hos Hamen betydelig bredere og endende med '2 stmmpt coniske, nedadkrummede Frontalfortsatser. Halen og Kjonsingene tilsammen neppe mere end halyt saa lang som den fodbarende Ilel af Koppen. Humnens Egheholder bredt afrumlet fortil med et limudeformigt Frem spring til hrer Side Hanneus ydre Kjonsredhang simpelt 'ylindriske og' ontrent af Halens halve La'ngde. Ginene kolleformige, omtrent af lıængle som Hovedets halve 'Trardiameter. Forste Par Folere forholdsris smaa, kortere end Oinene. Andet Par Folere hos Humen hetydelig kortere end $\mathrm{Ho}_{\mathrm{o}}$ redet, endende i en triangulær Flig; samme Folere hos Hammen særdeles store, tregrenede, de 2 forreste Grene tangformigt lirumnede i Enden og fint cilierede $\mathrm{i}$ den indre Kant, den bagerste Gren kort, lige nedad rettet og tret haaret i Ender. Halepladerne bredt lanretformige, omtrent dobbelt saa lange som le er brede ved Basis. Legemet gjennemsigtigt med sragt gronligt, blaaligt eller rodligt skjæer. Hannen sadvanlig lys gulagtig. Hunnens Kjonsringe oventil mel 2 nltramarinblar liantede Pletter, mellem hvilke er 2 smale Striber at samme Farve, Egbeholleren orangefarret nedentil. Hmnens Langde indtil $16 \mathrm{~mm}$, Hannens $10 \mathrm{~mm}$.

Bemærkninger. - 1)eme eiendommelige Phyllopode blev forst opulaget under Middendorffs Lieise i Sibirien og er kortelig beskrevet under ovenstaaende Navn af $S$. Fischer, sammen med andre under Rei. sen indsamlerle Entomostraceer. Den el senere ngsaa gjentunden at andre Forskele. nden at dog endnu nogen mere udfurlig Beskrivelse er leveret.

\section{Besklivelse af Humnen}

L wengden af legemet, fra. Panderanden til Eriden af Haleblarlene, naar oj til $16 \mathrm{~mm}$. Dog finder man den, saaledes som 'Tilfaldet er merl andre Phrthopoder, slagtsmoden lange for den har naaet denne Storrelse.

Legemet er (se Tha. IX, Fig' $10 \mathrm{~g} \cdot 2$ ) slankt, "rlindriskt, og nasten af ens Bredde, dog los tinlilt udvililede Individer kjendeligt op-rulmet loagtil i Kjonsregionen. Man kan alskille de samme Trmps-
Polyartemia forcipata. Fischer.

(P]. IX \& X).

Polyartemia forcipata, Fischer, Midelendorf's Siberische Reise, Bu. 2. Zoologie, p. 15t, Tab. III, fig. 24-2s.

Specific characters. - Body narrow eylindrical, of almost wniform thickness in the female, tapering in the male. Head in female comparatively small and rounded in front, in male considerably broader, and ending in two bluntly conical, ilecurved frontal processes. T'ail and genital segments trgether' scarcely more than half as long as the pedigerons part of the hody. Narsupium of female broadly rounded in front with a nodiform protuberance on each side. External sexmal appendages of male simple eylindrical, and about half the length of the tail. Fres club-shaped, abont the length of half the transverse diameter of the head. First pair of antenne comparatively small, shuter than the eres. Second pair of antennx in female considerably shorter than the head, and ending in a triangnlar lappet; in male very large, tripartite, the tro foremost rami being curved like a forceps at the end, and finely riliated on the inner margin, the hindmost ramus short; pointing straight inwards, and densely hairy at the extremity. Cauclal lamellæ broadly lancenlate, abont twice as long as they ale broad at the base. Body transparent. with a faint green, blue or red tinge: that of male senerally pale yellow. Genital segments of female above with 2 augular nltramarine-blue patches, between which there are two narrow stripes of the same rolour. Marsupinm orange-eroloned belori. Lengtl of female up to $16 \mathrm{~mm}$, that of male, $10 \mathrm{~mm}$.

Remarks. - This yeenliar Phyllopod ras first discovered dnring Middendorff's jommer in Siberia, and is briefly described under the above name by S. Fischer, together with other Entomostraca collected during that jomrney. It was subsempently also found by other natmalists, notwithstanding which, no more detailed description has as ret been furnished.

\section{Description of the Female.}

The length of the bodr, trom the trontal mal. gin to the end of the andal lamellie, attains to 16 mm. It is found, however, as is also the rase rith other Phylloporla, sexually nature long hefore it has attained this size.

The bodr (see Pl. IX, figs. 1 and 2) is slender, evlindrical, and of almost uniform breadth thronghont, though, in fully developer animals, preeptibly distended posterioly in the sexual rogion. The 
afsnit som hos Branchinecta, skjondt deres indbyrdes Langdeforhold er temmelig forskjelligt.

Hovedet el forloldsvis af linge Storrelse og stumpt afrundet fortil. Det afgrændser sig skarpt tra Nakkesegmentet, der til hrer Side viser Skalkjertelen meget tyleligt. Truncus er stærkt forlæuget, regelmassigt "vlindrisk, og delt i ikke mindre end 19 rel begraendsede S'egmenter, hvert bælende et Par Branchialfodder.

Bagkroppen udmærker sig i hoi Grad ved sin korte og plumpe Form, idet den neppe indtager mere end $1 / 3$ af Kropslængden. Kjonsringene er fuldstændig sammensmelterle saavel indbyrdes som med len bagenfor liggende Del af Halen, paa hvilken alene det bagerste Segment en tydeligt begraendset. Hele dette Parti har, seet ovenfra (Fig. 2), ell nasten predannet Form, idet det fortil er strekt fortykket og ligesom opblest, med en afrundet knndeformig Protuberans til hver Side, medens det bagtil gradris afsmalnes. Breden over den forreste Del af dette Afsnit el mere end dobbelt saa stor som Breden ovel selve Truncus. Sees Dyret fra Siden (Fig. 1), viser sig Storsteparten af den ventrale Side af dette Parti optaget af den voluminose Egbeholder, hris forreste Del er særdeles stærkt livælvet, medens den lagtil kmu rager ubetydeligt frem i Form af et kort koniskt Frem. spring. Paa Enden af dette Fremspring findes den ydre Aabning for Egheholderen, som hos Branchinecta, begreendset at 2 vertikale mod hinanden bevagelige Læber, hvorat den overste er den storste og eniler i en tilspidset Kmude (se Tab. X, Fig. 12). Halepladerne (se Tab. IX, Fig. 6) el forholdsvis korte, nejpe mere enl dobbelt saa lange som de er lrerle ved Basis, og viser en bredt lancetdannet Form, med spidsen smalt afrundet. De er hver liantede med omtrent 19 cilierede Borster der sucressivt tiltager i Langule nod Spidsen.

Ginene (Tab. I, Fig. 1, o) el forholdsvis korte on tykke, neppe længere end Hovedets halve Brede, og af den sadranlige parestannerle Form, merl Oiegholjen jævnt afrudet. Giepigmentet er morkt, dog hus det levende Dyr med at tycleligt jurpurrodt skjar, og de enkelte Synselementer vel ndviklede. l)et enkle Oie sees som en trdelig mork Plet i Midten at Horedets Panderlel.

For'ste Par Folere (1'ig. 1, a ${ }^{1}$, Fig. 3) er forholisris betydelig koltere end hos Branchinecta, neppe halvt saa lange som Oinene, men viser for"vrigt en meget lignende Bygning, og berer jaa siridsen de salvanlige I mgtepapiller og Foleborster.

Andet Par Folere (Fig. 1, a ${ }^{y}$ ) er ligeledes mindre end hos Bronchinecta, og har Formen af 2, som det synes, fnldkommen ubevagelige treliantede Flige, same body-divisions can be distinguished as in Branchinecta, although their mutual relations as to length are rather different.

The head is comparatively small and bluntly rounded in front. It is sharply defined fiom the cervical segment, which shows the shell-gland on each side very distinctly. The trumk is greatly elongated, regnlarly cylindrical, and divided into no less than 19 well-defined segments, each bearing a pair of branchial legs.

The posterior part of the body is highly remarkable for its short and stout form, constituting, as it does, scarcely $1 / 3$ of the length of the body. The genital segments are completely coalesced, both mutually and with that part of the tail posterior to them, in which only the hindmost segment is distinctly detined. The whole of this part, seen from abore (fig. 2), is almost pyriform, being rery much thickened in front, and as it were inflated, with a rounded, nodiform protuberance on each side, while posteriorly it tapers gradually. The breadth of the front part of this section is more than double as great as that of the trunk itself. When the animal is seen from the side (fig. 1), the greater part of the ventral side of this region appears to be oceupied by the voluminons marsupium, the anterior part of which is boldly convex, while the posterior end projects only slightly in the form of a short, conical prominence. At the end of this prominence is seen the extemal opening of the marsupium, bounded, as in Branchinecta, by 2 movable lips, the upper of which is the larger, and ends in a pointed module (see Pl. X, fig. 12). The caudal lamella (see Pl. IX, fig. (6) are comparatirely short, being scarcely more than double as long as they are broad at the base. They exhibit a broadly lanceolate shape with the point narrowly rounded, and are each fringed with about 19 ciliated bristles, which snecessively increase in length towards the point.

The eyes (Pl. X, fig. 1, o) are comparatively short and thick, scarcely longer than half the breadth of the head, and of the usual pyriform shape, with the eye-ball evenly rounded. The pigment is dark, though with a distinct tinge of arimson in the living animal: the risual elements are well-developerl. The ocellus is observable as a distinct dark spot in the centre of the frontal part of the head.

The first pair of antennæ (figs. 1, $\mathrm{a}^{1}$ and 3 ) are "omparatively much shorter than in Branchinceta. being scarcely half as long as the eyes, but in other ways exhibit a very similar structure, and carry at the extremity the usual olfactory papillæ and sensory hristles.

The second pair of antennæ (fig. 1, a ${ }^{2}$ ) are also smaller than in Branchinecta, and have the form of 2 apparently perfectly immovable triangular lappets 
der hver har en dyb Indbugtning fortil ner Spidsen. Langs Forkanten findes en Del meget smaa liaarformige Borster, der synes at vare Foleredskaber, da der til enhver af dem gaar en fin Nervetraad.

Overlaben (Fig. 1, T, Fig. $4 \mathrm{og}^{\prime} 5$ ) har Formen af' en bred, næsten firkantet Lap, der nedad rager ud over Kindbakkernes Tyggedel. Paa Indsiden af deme Lap er der en langsgaaende, delvis haaret Forhoining, der ender bagtil $\mathrm{i}$ en frit fremragende, verticalt stillet Lob at smalt tungedannet Form (se Fig. 4 og 5).

Kindbakkerne (Fig. 1, M, Fig. 6) har den for Branchipodideme characteristiske Bygning, og ender med en fint riflet Tyggeflade, wden tydelige tandformige Fremspring.

Forste Par Kjæver (Fig. 1, m ${ }^{1}$, Fig. 7) har den bladformige Endedel af betydelig Storrelse og besat paa ren trært afkuttede Ende merl en tæu Rad af onkring 24 indadkrummede Borster af en lignende Beskaffenhed som de hos Branchinecta.

Andet Par Kjæver (Fig. 1, m², Fig. 8) er forholdsvis smaa og idethele af en simplere Bygning end hos Branchinecta, uden tydelig Adskillelse mellem Basal- og Endedel. De er i den ydre, noget udvidede Del tæet haarede og har kun 2 cilierede Borster fæstede til det indre Hiorne samt en betydelig mindre simpel Borste i den indre Kant, omtrent $\mathrm{i}$ Miclten.

Branchialfodderne er 19 Par i Antal, svarende til de 19 Kropssegmenter. Naar undtages sidste Par, er de alle af ens Bygning og viser alle de Dele, som ovenfor er adskilte hos Branchinecta, hvortil endnu kommer en egen Plade ved Basis paa den ydre Side, hvoraf der intet Spor er at opdage hos hin Slægt. Det forreste Par (Fig. 9) er noget mindre end det $2 \operatorname{det}$ (Fig. 10), de folgende noget nær af ens Storrelse indtil omtrent det 12te Par, hrorefter de suceessivt aftager i Storrelse lagtil. Paa dem alle er selve Stammen, eller Endopoditen, meget bred, pladeformig, med den forreste Flade noget hvælvet. Dens yderste Jap er meget stor og næsten tvært afkuttet i Enden, samt kantet med stærke Borster, hroraf dog ingen som hos Branchinceta, er kloformige. De 3 oventil folgende Lappe er saerdeles smaa og tæt sammentrængte, af konisk Form, og hver besatte med 2-3 længere og et Par kortere Borster. Den næstoverste Lap er kun utydeligt skilt fra den overmaade brede, halvmaaneformige basale Lap, og hegge kantede med en tæt og regelmassig Rad af meget lange og leformigt krummede Borster, alle tydeligt leddede paa Midten. Exoyoditen er forholdsvis liden, og har Formen af et ovalt Blad, forbundet med den ydre Del af Endopoditen ved et tydeligt Led. Den er kantet med stærke, cilierede Borster, hvoraf de fra Enden ndgaaede er længst. Epipoditen er af et ligmende Udseende som which each have a leep notch in front, near the point. Along the front elge there is a number of minute laair-like bristles, which appear to be sensory organs, as a fine nerve-fibre runs to each one.

The labrum (figs. 1, I, 4 and 5) has the form of a broad, almost square lobe projecting downwards over the mastinatory part of the mandibles. On the inner side of this lobe, there is a longitndinal, rather hairy prominence, which ends posteriorly in a freely-projecting, vertically-placed lobe of a narrow, lingniform shape (see figs. 4 and 5 ).

The mandibles (figs. $1, \mathrm{M}$ and 6 ) are of the structure rharacteristio of the Branchipodidx, and end in a finely-flnted masticatory surface without any distinet dentiform frojections.

The lamelliform terminal portion of the first pair of maxille (figs. $1, \mathrm{~m}^{1}$ and 7 ) is of considerable size, its abruptly truncated end being furnished with a close row of aloont 24 inward-enring bristles of the same structure as those in Branchinccla.

The second pair of maxillat (figs. $1, \mathrm{~m}^{2}$ and 8) are comparatively small and, on the whole, of a simpler structure than in Branchinecta. withont any distinct separation between the basal and the terminal parts. In the onter, somewhat expanderl part, they are densely hairy, and have only 2 ciliated bristles attached to the imner corner, and one much smaller, simple bristle at about the middle of the inner margin.

There are 19 pairs of branchial legs, corresponding to the 19 segments of the body. With the exception of the last pair, they are all of a miform structure, and exhibit all those parts which have been already distinguished in Branchinecta, with the addition of a peculiar lamina at the base on the onter side, of which no trace is to be found in that gems. The foremost pair (fig. 9) is somewhat smaller than the second (fig. 10), the succeeding pairs being of almost uniform size until about the 12th pair, after which they successively decrease in size posteriorly. In all of them the stem, or endopodite, is very broat, lamellar, with the anterior surface somewhat ronvex. Its outermost lohe is very large and almost abruptly truncated, besides being edged with strong bristles, none of which, however. are claw-like as in Branchinerta. The 3 succeeding. lobes above are exceedingly small and closely crowded, conical in shape, and each amed with 2 or 3 long, and a couple of shorter bristles. The nppermost lobe lut one is only slightly separated from the exceedingly broad, crescent-shaped, basal lobe, and both are elgerl with a close, regular row of very long and falciform luistles, all distinctly jointed in the middle. The exopodite is comparatively small and of the shape of an oval leat, mited to the onter part of the cndopodite by a distinct articulation. It is edged with strong, ciliated bristles, 
hos Branchinecto, damende en aflang oral spongios Plade, mden Spor af Borster. Ovenfor denne er til Idersiden af Stammen frstet 2 tillels hinanden dækkende tynde, afrumdet ovale Plader, der begge maa opfattes som Drinlader. De er af noget nlige Storrelse, idet den overste er adskilligt mindre end den nederste, og begoe hav Kanterne ganske glatte, uden spor af sagtakker.

Sidste Fodpar (Fig. 11) skiller sig fra de orrige, frruden red sin ringe Storrelse, ved den fuldstandige Mangel saavel af Epipodit som Basalplader. Exopoditen er særdeles liclen og kim forsynet med 6 Randborster. Endopoditens ylerste Lap er langtfra saa fremragende som par de ovrige Par og har et ringere Antal af Randborster, alle ganske korte. Ligeledes er Borsterne paa de 2 basale Lappe betydelig mindre ndviklede end paa de orrige Par, og knu ganske sragt boiede.

\section{Beskrivelse af' Hanneu.}

Uligt hrad Tilfældet er med Branchinecta og som det synes ogsaa med andre Branchipodider; er Hamnerne af narvarende Form giennemgaaende noget mindre end Hmmerne og overskrider neppe en Læugde af $10 \mathrm{~mm}$.

Legemet er (se Tal. IX, Fig. 3 og 4) noget mindre langstrakt, og baade Hovedet og Halen ræsentlig nlige samme hos Humnen. Hoverlet er af meget betydelig Storrelse og viser urentil et sadelformigt Indtryk. Fortil ender det med 2 fingerformige og noget divergerende Pandefortsatser, der er nedadkrmmmerle og silte i Midten red et halr. maaneformigt Indsnit (se ogsaa Tab. X, Fig. 2). Til hrer Side, tilsyneladende sum en uniddelbar Fortsiettelse af Hovedet, udgar med en bred Basis de eiendommeligt formele Gribeantemer (se Tab. IX, Fig. 3 og 4, Talı. X, Fig. ') . Enlver af disse ex delt i 3 paa hinanden folgende indadkrummede fingerformige Grene, hroraf den furreste ex storst ug synes at forestille rlen egrentlige stamme, meden. de 2 ovige narmest er at hetragte som secundare Sidegrene. Den lagerste Gren er hetrdelig mindre end le ovrige, stmmpt tilmmlet i Enden, og rundt om besat med fine Haar, medens de 2 orrige km lnaarede langs ad den inclre concare Kant (se Tab. 1X. Fig. 5). Sammen med de 2y pandefortsatser vil risse Lemmer, naar de bries ind mod hinanden, kumm virlie som et sardeles ptfelitivt Gribe- og Fastholdningsapuarat.

Winene, Jste Par Folert, Mumdlelene og Branwhiltodderne skiller sig i ingen Henseende tra samme hos Hummen.

Derimod er Bagkroplen meget forskjellig og be- those at the end being the longest. The epipqdite lesembles in appearance that in Branchinecta, and forms an oblong, oval, spongy lamella, witliout a trace of bristles. Above this, to the onter sidp of the stem, are fastened 2 thin rounderl oval laminx, partly overlapping one another, which must be regarded as cover-plates. They are somewhat mnequal in size, the upper one being eonsiderably smaller than the lower; and the edges of both are quite smootl, withont a trace of serrations.

The last pair of legs (fig. 11) are distinguished from the others not only by their small size, but also by the total alssence of both epipodite and basal laminæ. The exopodite is very small and furnished with only of marginal bristles. The qutermost lube of the endopodite is not nearly su projecting as in the other pairs, and las a smaller number of marginal bristles, all quite short. The bristles on the two basal lobes are also considerably less developed than in the other pairs, and only slightly curved.

\section{Description of the Male.}

Unlike the Brunchinecta, and also, as it seems, the other Branchipodiclæ, the males of the present species are generally rather smaller than the females, and sarcely exceed $10 \mathrm{~mm}$. in length.

The body (see PI. IX, figs. 3 and 4) is somewhat less elongated, and both the head and the tail are essentially mulike those parts in the female. The head is of rery considerable size, and exhibits above a saddle-like depression. It ends in front with two digitiform, and somewhat divergent frontal processes, which are curved downwards and divided in the middle by a cresent-shaped notch (see also Pl. X, fig. 2). On each side, from a broad base, there issue, apparently as an immediate continuation of the head, the peculiarly formed prehensile antenna (see Pl. IX, figs. 3 and 4, PI. X, fig. 2). Each of these is divided into 3 snccessive, incurved, digitiform rami, of which the foremost is the largest, and seems to represent the stem proper, while the other two may be ronsidered more proper? as secondary lateral branches. The hindmost ramns is considerably smallex than the others, is bluntly pomnded at the end, and fringed all round with fine lıairs, while the other two are only hairy along the imer concave edge (se P. IX, fig. 5). In conjunction with the two frontal processes these two limbs, when bent in towards one-another, can act as a most effectual seizing and holding apparatns.

The eres, the tirst pair of antennæ, the oral jarts and the loranchial legs do not differ in any respect from those organs in the female.

The posterior division of the hodr, on the other 
tydelig smekrere end hos Humen (se Tah. IX, Fig. 3 og 4, Tab. X, Fig. 6). De 2 Kjonsringe er tydeligt adskilte $i$ sit dorsale Partiog er, ovenfra seede, neppe bredere end Truncus. Derimod damner cle nedad en noget mregelmassig Udvidning, hrorfra de vdre Kjonsvedhang ndgaar. Disse sidste ex forholdsvis storre end hos Branchinecta og af noget nær rylindrisk Form, eller knn ganske svagt afsmalnende mod Enden, og har det ydre Parti tat besat med fine Haar. Den bagenfor liggende Del, den egentlige Hale, afsmalnes gradvis hagtil og er, uligt livad Tilfaldet er hos Hmmen, delt i i tyrleligt lıegrandsede Segmenter, foruden Halegrenene. Disse sidste er fuldkommen af samme Tidseende som hos Hnmen.

Farve. - Legemet er hos begge kjon i levende Tilstand meget gjennemsigtigt, saa at de indre Organer mere eller mindre tydeligt skinner igiennem de tyonde Integumenter. Hos Hunnerne has det ialmindelighed et svagt gronligt Anstrog, medens det hos Hamnerne riser en lys gulagtig Tone. Dog varierer Farven letrdeligt hos begge Kjon efter Lokaliteterne og spiller undertiden over i det blaalige eller rodlige. Hos fuldt ndviklede Huner findes meget constant (se Tab. 1X, Fig. 1 og 2) paa Rrgsiden af Kjonsregionen 2 sidestillede rndeformige Pletter af' en intensiv nitramarinblaa Farve og ind fattede af en morkere Kant. Enhrer af' disse Pletter forlænger sig sædranligris fortil i en smal Stribe af samme Farve, og mellem begre disse sees ialmindelighed 2 andre tæt sammenstillede Længdestriber af en lignende Couleur. Den forreste Del at Figbeholderen er i Regelen orangefarret, medens len bagerste Tel viser nogle uregehmassige violette Shatteringer. De i Egheholderen indsluttede Ag. er morkt gronfarvede. Hos Hannerme er ofte Spirserne af Gribeantennernes Grene mere eller minlre tydeligt orangefarvede, og mudertiden det bagerste Segment af Halen violet anstroget (se Tab. IX, Fig. $3 \circ \log 4$ ).

\section{Indre organer.}

Tarmen strækker sig, som hos Branchincetu, i Form af et simpelt cylindriskt Ror igjemem hele Legemet (se Tab. IX, Fig. 1-4), og er iahninclelighed fyldt med orangefarret Inthols, der bagtil grarlvis antager en morkere brunagtig Farve. 1 Hovedet udgaar fra Forenden at' Tarmroret ? korte Blindsakke af en lignende Strnctur som hos Branchinecta. Spiseroret (Tab. X, Fig. 4, 5, o) viser red sin For hindelse med Tarmoret en eiendommelig klapformig Indretning, ligesom der paa dette Sterl tindes et Slags chitinagtigt Stotteapparat besat med et Antal af strerke, i Tarmens indre frit fremspringende borstetormige Fortsatser, cilierede i Kanterne. Endetar. hand, is very different to, and mnch more slender than that of the female (see Pl. IX, figs. 3 and 4 ; Pl. I, fig. 16). The two genital segments are distinctly separated in their dorsal part, and, when seen from above, are scarcely hroaler than the trumk. Below, however, they form a somewhat irregular expansion, from which the external sexnal appendages issue. The latter are relatively larger than in Branchimecta, and nearly cylindrical in form, being only very slightly tapered towards the end, and with the onter part covered with fine hairs. The postexior portion, or tail proper, tapers gradually towards the end, and, nnlike that of the female, is divided into is distinctly-defined segments, besides the candal rami. The latter are of exactly the same appearance as those of the female.

Colour. - In the living state, the body in both sexes is very transparent, so that the internal organs are trared more or less distinctly through the thin integuments. In the females, it has generally a faint tinge of green, while in the males, it exhibits a light yellow slade. The colom varies, however, considerably in both sexes, according to the localities, and sometimes has a bhe or a red tint. In fully developed females, there is very generally found (see Pl. IX. figs. 1 and 2 ) on the dorsal side of the sexnal region, 2 juxtaposerl, diamond-shaperl patches of an intense nltramarine-blne, suromnded by a darker rim. Each of these patches is generally prolonged anterinly into a narrow stripe of the same colonr, and between them are generally to be seen two other longitudinal stripes of the same rolonr, placel rlose together. The anterior portion of the marsupinm is, as a rnle, orange-colomer, while the posterior part exhibits some irregular purple markings. The eggs puclosed in the marsupium are of a dark green colour. In the males, the tijs of the rami of the prehensile antemne are frequently more or less distinctly orange-colonred, and the hindmost segment of the tail is often tinged with purple (sep Pl. IX, figs. 3 and 4 ).

\section{Internal Oromss.}

As in Branchinecta, the intestine runs in the shape of a simple "ylindrical tube throughont the length of the body (see Pl. IX, figs. 1-4), its contents heing generally of an orange-colonr, gradnally assmming a darker brown hne posteriorly. From the anterior end of the intestinal tube, in the head, there issue 2 short caca of a structme similiar to that in Branchinecta. The resophagus (Pl. I, figs. $4,5,0)$ exhibits at its junction with the intestinal tube, a pectlial valve-like arrangement, and also at the same place a kind of chitinoms smplort, clothed with a number of strong, setiform spikes with riliated edges, freely projerting inside the intestine. 
men er, som hos Branchinecta, kun indskranket til sidste Halesegment, og viser en lignende Brgning som hos denne Silægt.

Nervesystemet synes idethele at ræe bygget paa samme Maade som hos Branchinectu, alene med den Forskjel, at Buggangliekjaden her er sammensat af et betydelig storre Antal Ganglier, overensstemmende med det storre Antal S'egmenter i Forkiroppen.

Ovarierne (Tab. I, Fig. 12, 13, osv.) er her kun indskrænket til Kjonsugionen, idet de ligger til hver Side verl Basis af Egbeholderen, uden at strakke sig ind. hverken i Forkruppen eller i den bagenfor: Egheholderen liggende Del at Halen. De danner 2 liorte cylindriske srekke (Fig. 14), i hris Indre ialmindelighed knu findes en enkelt Rakke af sig ndviklende storre $\mathrm{Eg}$ fyldte med gron Plommemasse, og desfornden, mere uregelmassigt fordelte, et Antal af meget smaa klare Celler med trdeligt fremtradende Kjerne. Omtrent fra Midten at hvert Ovarimms indre Kant udgaar Eglederen, der viser paa Midten en stærk, sæktnrmig Udvidning og munder i det indre af' Egbeholderen. Mundingen er delvis omgivet af en meget voluminos Kjertelmasse (Fig. 12, 13, gl), der strakler sig igjennem hele Egheholderens Lirngde, og som atgiver Stoffet til den stærke Skal, hvormed Aggene her ongives. De modne af Ovarierne udkomne $\mathrm{Eg}$ ligger mregelmassigt ordnede $\mathrm{i}$ Egheholderens Silermm (se Ta]. IX, Fig. 1 og 2) og nultommes med risse Mellemrum gjennem dens klapformige Munding. De er da (se Tab. X, Fig. 15) omgivne af en temmelig tyk og meget fast whitinos Skal, der ved stærk Forstorrelse viser sig nregelmassig reticuleret. Egindholdet er ensformigt kronet og af en meget mork gron, i det brunlige spillende Farve. Nogen Segmentering af Egget har jeg ikke kumet paavise.

Testes (Tab. I, Fig. 16, t) indtager omtrent samme Plads som Ovarierne, skjondt de strakker sig lidt ind i den bag Kjonsringene liggende Del af Halen. De har Formen af 2 smale Srkke, tilspidserle i hver Ende, og noget tykkere fintil end loagtil Noget hagenfor den forreste Ende udgar fra den nedre Side Swdlederne, der, som hos Branchinecta, danner en temmelig strerk, tredelt Udvidning (vi): hvorpaa de hver antager Formen af en trang: Kranal. Denne gjor en stark slyngetormig Boining, inden den traeler ind $\mathrm{i}$ de ydre Kjonsvedhæng, paa hris Śpids den udmmoler.

\section{Trikiliug.}

Ogsaa if demne For'm har jeg lpilighedsvis havt Anledning til at undersoge Here Trviklingstrin, uden at det log enduu har lykkets mig at faa studeret den hele Udrikling fra torst af.
The rectum, as in Branchinectu, is limited to the last candal segment, and exhibits a structure similar to that in the above-named genus.

The nervous system seems, on the whole, to be constructed in the same manner as in Branchinecta, with the one difference that the ventral ganglion chain is composed of a considerably larger number of ganglia, corresponding to the greater number of segments in the anterior part of the body.

The ovaries (Pl. X, figs. 12,13, or) are contined to the genital region, and lie one on each side of the base of the marsupium, without extending either into the anterior part of the body, or into the caudal region behind the marsupinm. They form two short cylindrical bags (fig. 14) within which there is generally only a single row of eggs undergoing development, and filled with a green yolk-mass, and also, more irregularly dispersed, a number of minute clear cells with distinctly conspicuous melei. From about the middle of the inmer edge of earh orary, issues the oviduct, with a large sac-like dilatation in the middle, and opens into the inside of the marsupium. The month is partially survomded by a very rolmminoms glandular mass (figs. 12, 13, gl), which extends throngh the entire length of the marsupium, and secretes the substance for the strong shell with which the egg becomes here surroumled. The mature ova that have come out of the ovary, are irregularly arranged in the lateral spaces of the marsupium (see Pl. IX, figs. 1, 2) and are evacuated at certain intervals through the valve-like month. They are then (see Pl. X, fig. 15) enveloped in a tolerably thick, and very firm rhitinous shell, which on being highly magnified appears irregularly reticulated. The contents of the orum are nniformly granulose and of a very dark green colour with a tinge of brown. I have been mable to discover any segmentation of the ormm.

The testes (Pl. X, fig. 16, t) occupy about the same place as the ovaries, though they extend a little way into that part of the tail lying behind the genital segments. They are in the form of 2 narrow bags, pointed at both ends and rather thicker in tront than behind. From the inferior side, a little behind the anterior end, issue the efterent ducts forming, as in Branchinecta, a rather strong, bipartite expansion (vd), wherempon each assumes the form of a narrow chammel. This makes a spiral curve before it enters the external sexual appendage, at the point of which it opens.

\section{Development.}

I lave occasionally had the opportunity ot examining several developmental stages of this torm also, although I have not ret succeeded in studring its whole development trom the very begimning. 
Let tidligste larrestadium, jeg har fundet, w ufbildet Tab. IX, Fig. 7 . Det srarer, hrad Lemmemes Thrikling angaar, noget ner til det Tal, V111, Fig. 15 afbildede Stadium af Branchinecta, men skiller sig markeligt derverl, at de sammensatte line, der los hint Stadium neppe endun ran anlagte, her er meget trileligt og umtrent ligesaa vidt komne som paa det $i$ andre Henseender meget videre udviklede Stadium af Branchincta, sum el tremstillet Fig. 17 paa samme Planche. Det synes altsaa som um disse Organer nurikles betrdelig tirlligere hos nerverende Phylloporle. De 2 Par Fo lere og Kinilbakkerne med sine Palper stemmer illet liele megnt noie merl samme los det tilsvarende Stadimm af Branchinecta, alene med den Forskjel, at den inderste af' de 2 fra 2 det l'ar Foleres Skaft nu gaaende, imladkrummede Fortsatser her er simpel, iklie trekloftet. If Branchialforder er der kim tilstede $7-8$ srage Anlxg i Form af simple Trerrulster til hrer Side af Kropyen, som allerede viser en tyclelig segmentering. Haleenden er noget indsnoret red liawis og ender med 2 meget korte lajpe, liver bærende en enkelt Borste.

Den ridere Ldvikling foregaar paa en fuldkommen lignende Naale som los Bronchinecta, irlet Branchialfodderne sucessivt untvililes forfra bagtil, medens 2let I'ar Folere og Mlandibularfodkerne gradvis reduceres.

\section{Forekomst og Leveris.}

Narverende eiendommelige Phyllopode er meget almindelig overalt i Finmarken. Jeg har truffet den paa folgenle Lukaliteter: Bugo paa Sydsilen at Varangerfjorden, Vadso, Fastlandet indenfor Varto paa mange Stedet, Vagge Tanafjurd, Nehavn, Hasvig paa Here Steder, Hammerfest ligesaa. Liengere Syrl paa Landet har ieg derimod aldrig stodt pra den, og den synes saaledes hos os ndehkkende at være indskrænket til den arktiske \%une. Ilen forekommer under lignende Furhold sum Bronchinecta pahudosa og ikke s.jelden sammen med den. Det er iscer i ganske grumle Smatjern med mudret Pund og som un paa Sommeren telvis eller tuldstamlig nultorres, at den paatraftes og her ofte $\mathrm{i}$ enorme Mrenguler. Dog har jeg ugsaa af og til truffet den i storre og dybere Taute. f. Ex. i et Tjern paa Hoideplateanet ved Tagge i Bunden af Tanatjonden, luvor den riste en vakker blaalig Farretegning. Den sxommer ialmindelighed om i Vaulet mere eller minulpe nær Orerfladen ong med en ganske jevn Fart, altid med hyggen nedarlvemit. Hamer og Humer troffes meget ofte i copnlation, og Hannen fastloolder hermder Humnen saa kraftigt med sine Gribeantemer om Kionsegionen, at let ikke
The earliest larval stage that I have foumd is figured in Pl. LX, tig. 7 . As regards the development of the limbs, it answers to the stage of Branchinecta represpnted on Pl. VIII, tig. 15, with the remarkable difference that the compond eves, which, in that stadium, had searcely commenced to appear, are bere very distinctly develnped, and are ahont as far advaned as in the, in uther respects, mols turther developed stadium of Branchinecta shown on fig. 17 of the same plate. It therefore seems as if these urgans were dereloped much earlier in th" present Phyllopod. The two pairs of antenna and the mandibles with their palpi agree on the whle very pxactly witl those organs in the corresponding stage of Branchinceta, with the one rlfference, that the imner of the two incurved processes starting from the scape of the secmul pair of antenno are here simple, not hifid. There are only $t$ or $s$ slight rudiments of lranchial legs in the torm of simple transverse prominences on each side of the body, which already shows distinct articulation. The extremity of the tail is somewhat constricted at the hase, and ends in two very short lohes, each carring a single loristle.

Furtler development proceeds exactly as in Branchincete, the branchial legs develuping sncessirely from tiront to bark, while the enct pair of antemate and the mandilunlar legs gradually oliminish.

\section{Occurrence and Hahits.}

This peculiar Phyllopod is rery eommon over the whole of Finmark. T lave met with it in the following localities: Bugo, rum the sontly side of the Varanger Fjorl; Tadso; in many places on the mainland sonth of Vardo; Vagge on Tana Fjord; Nehavn; Hasrig in many placps; also Hammerfest. (1n the other hand, I have never come numses it further south, and it thus seems, in this comotry (Nonway) tu be contined to the aretic zone. It is fonnd unler the same onditions as. anl not infrequently together with Branchimecte paludosa. It is especially in quite shallow, small lakes with muldy bottom, and which either partly or completely dry np towards the end of the smmer, that it is met with, and there uften in very great numbers. 1 have, however, now and then also found it in larger, deeper lalks, e. $g$. in a lake on the platean at Vagge, at the head of Tana Find, where it was of a heantifnl hlue rolour. It generally swims about more "r less near the surfare of the water at an even rite, and with its hack alwars tmoll down wards. Nales and females are often fomd in 100 mlation, during which the male rlasps the female su firmly with its prehensile antema ahout the genital 
sjeldent lykkes at faa begre $\mathrm{i}$ Simmenhang conserveret paa Spiritus.

Udbredning. - Arten hlev forst ojdaget af Middentorft i Smatjern paa den sihiriske. Tundra» ved Flodeme Tamm "g Boganila, ligesom ogsaa i Russisk Lafland red Tri-l strowa, ug er senere af Fries gienfunden i (sttimmarken. Derimod er den ikke kjendt hrerken fra dirmland, det arktiske Amerika eller spitsberan.

\section{Sectio II. Notostraca.}

(Slijolddælite Phrllopoder).

\section{Sym: Ployllopoda caneriformia.}

Character. - Legemet nere ellex mindre dak ket oventil af et bredt liviplret lirgkindd, der fortil er sammenvoxet merl Hovedet. Kroplen ensformigt segmenteret, jernt atsmalnende bagtil, og en. dende med 2 torlangede Haletraale. Ginene sessile, nær sammen par (versiden af Hoverlet. Andet Par Folere hos det voxne Inv rudimentare ellez ganske manglende. Mundilelene tret simmentrangte bag. Horedets rentrale Inpirintur, og bestacende af Grer og Lnderlahe, Handibler og 2 Par Kjæver. Fodderne overordentlig talipe og tat sammentrangte bagtil, saa at Here l'al" ex fasterle til hrert mkelt segment. Ingen rdre Agbehulder. Tdriklingen en compliceret Metamorphose begrndende mer et Naupliusstudium.

Bemærkninger. - Niprviprende (truple adskillew sig neget skarpt fra de wrige Phyllopoder ved en liakke vel markelede Charaterer, hroraf den mest ioinefaldende el det thut livalvade liygsijold, del tortil gar i et mel Hoverlet og giver Dyret en umiskjendelig lighed med Iiphosmene ng derigjennem ugsaa mea de turverdenske Tritobiter. Med liss sidste stemmer ogsa narrerende Gruppe wereus red det overomlentlig store Antal af mi(i)line Segmenter, hvori legemet er delt. Idethele symes flere ('haraterer, der ndmarkede nogle af he aldste forrerdenske Cmstaceer, tydeligere at afspeile sig i narrarende (irnppe end i nugen af de ovrige. Ten indeholder for' 'Tiden hum en enkelt Familie. region, that it is often posible to preserve both together in spirit.

Distribution. - This species was first discovered by Middendortf in small lakes on the siherian "Tundra at the livers Taimm and Boganida, and also in linssian Lapland at Tri-1strowa; it was suhsermently found again by Fies in Fast Fimmark. It has nut, howerer, been heard of either from freenland, aretir Amerioa or spitzbergen.

\section{Section II. Notostraca.}

Shield-bearing Phyllopods!

Sym: Phyllopoda cancriformia.

Characters. - Bodr more or less nvered above by a loral, vanted caraluace, whirh is mited anteriorly with the heal Trunk uniformly segmented, tapering prenly posteriorly, and ending in two elongated caudal filanents. Eves ressile and rlose together on the mpper surtace of the hear. Sernud pair of antenut in the full-gromn animal pither rndimentare or altogetler wanting. Oral parts olosely crowled behind the rentral duplicatme of the head. and rumsisting of upper and lower lip, mandibles and \& pairs of maxille. Legs extremely nmeroms and rlosely crowded together josteliurly. so that several pairs are attached to each segment. No external marsupinm. Development. a complicated metamorphosis, commenuing with a manplins stactim.

Remarks. - The present group' is sharply definer from other Phrllowoda by a series ot well-marlied chancters, "ff which the most conspirnons is the vanlted rarapare whirh is mited with the head, giving the animal an unmistaliable likeness to the Tiphosure, and therebr also to the praleozoic Trilobites. With the latter the present grwup also agrees, in the extraortinarily large number of uniform segments into which the body is divided. Taken as a whole, several ot the characters that distingnisher sume of the uldest paleozoic rustacea, seem to be reflerted more "learly in the present gromp than in ans of the others. At present, it contains omly at single family. 


\section{Fam. Apodidæ.}

Character. - Rirgskjoldet bredt atimulet tintil, fladt hrielvet, og indskanet bagtil, med en trilelig transverxal Nakkefure, begrændsende Hovedet bagtil; det sidste sliorlformet, visenle en halvmaaneformic ventral Duphiotur, hag hrilken Foleve og Nunlilele har sin Plads. Den bagre Del af Legemet mere eller mindre fremragende Irag Rygskjoldet "g' delt i talrige korte, med tine Turm omkranclsede Segmenter. Haletradene stærkt forlæungede. Overlaben bred, klapformig; Underlæben tvekloftet. Kindlakkerne med grort tandet Fg. 1ste Par Kiprer oxeformige: 2det Par merl en membranos lateral Fortsats. Alle Foddr med tydeligt begrandset Coxallap; 1ste Par mere eller mintre ulige de wrige, med Enditerne traadformige; de næst tolgende Pin prehensile, med Enditerne delvis kinformige; 11te Par hos Hunnen merl Epi- ug Exopoditen omformerle til en kaprelformig Egbeholder. Hannerne meget xjeldne, hetydelig mindre end $\mathrm{Hun}$ nerne, og ulen sperielle prehensile Organer.

Bemærkninger. - Deme Familie indeholder kun ¿ Slægter, Ams og Lepidurus, der staar hinanden orer'maade nær, og begge har en meget rid geographisk L'dbredning, idet de er representerede baarle $i$ den nye og gamle Terden, ligesom ugsaa i Anstralien. Kun den sidste af hisse Nirgter er reprasenteret i ror Fauna.

Gen. Lepidurus, Leach, 1816.

Slægtscharacter. - Rygkjoldet ialmindelighed meget stort. dielikende den storste led af Kioppen ug forsynet bagtil med en mere eller minulre udproget langsgaaende iorsal Kjol. Silste Halesegment torlanget mellem Haletradene til en pladeformig Cdvidning. 1ste Folpar med Enditerue forholdsvis korte, kmn lidet orerragende livgskjoldets Rand. t:5 Fodpar tilstede. Forovrigt overensstemmende med slaggten Amus.

Bemærkninger. - Den her umlandlede slagt er forst ontillet at den bekjenite Naturforsker Learh, "g rasentlig waracteriseret reel Tilstedevarelsen at en median Haleplade, der ganske manglex hos Ams, sant ved do forholikvis liorte Enditer par 1ste Fodjar. Ina midlertil toroviget le lerhen horende Arter pa let nojeste stemmpr overens med Amus, siavel i vilre Halsitus som i de anatomiske

\section{Fam. Apodidæ.}

Characters. - ('arapare broadly rounderl in tront, slightly vanlterl and indented behind, with a distinct transverse cervical furmw defining the heal josteriorly; the latter shovel-formed and exhiliting a rrescent-shined rentral inplicature, behind which the antemne and oral parts are situated. Hind part of the budly projecting more or less behind the carapace, and divided into numerous segments, encireled by fine spikes. ('andal tilaments very much rlongated. Anterion lip broad and flap-like; posterion lip biticl. Mandibles with the cutting edge warsely dentated. First pair of maxillw seatuitorm, strond pair with a membranous lateral expansion. All the legs with rearly definerl roxal lobes; first pair more or less mulike the remainder, with the endites filiform; the next pairs prehensile, with the endites partially "aw-like; 11th pain in the female, with the epipodite and exopodite transformed into a capsular orisac. Males very rare, considerably smaller than the temales, and without special prehensile organs.

Remarks. - This family "ontain my two genera, Apus and Lepidture, which are very nearly allied, and both hiave a very wide geographical distribution, being represented both in the rild and the new world, as also in Anstralia. Only the latter of these two genera is representerl among the Norwegian tanna.

Gen. Lepidurus, Leach, 1816.

Generic Characters. -- ('alapace nsually very large, covering the greater part of the bodr, and turnisher pusteriorly with a more or less markerl longitudinal dorsal keel. Last uandal segment prolonged between the camdal tilaments to a lamellar expansion. First pair of legs with the endites comparatively short and projecting only slightly beyond the edge of the carapace. There are 63 pairs of legs. In wther respects it agrees with the genus Aptes

Remarks. - 'The genus here treated of was first establisherl by the well-known English naturalist, Leach, and is rharaterised mimipally hy the presence of a median undal lamella, which is altogether absent in $A$ me, and by the compraratively short endites in the first pair of legs. As, however, the species helonging to this grenus agree in other 
Detailler, kan det rare et Śporgsmaal, om disse? Slaegter i Tirkeligheden altid lader sig holde skarut nd fra hinanden. Man vol nemlig finde, at Enditernes Trengle paa lste Forlpar ex los Arteme af slaegten Lephihus ikke lidet varierende, og Halppladen er ialfald hos enkelte Arter sa betydelig rednceret i Stomelse, at den nasten maa lialdes rulimentær. Ryskjoldet er vistnok ialmindelighed stor'e hos Lepidums end los ipus, og dækker dertor lus den forste strent en storre Del at Kroppen end hos den sidste; men man vil dog finde. at der ogsaa i saa Hensende er adskillig Tariation hos Arterne af begge slagor. Hos Lrpulums glucialis er det saledes neppe synderlight storre end los L Ims cancriformis, og hos den norlamerikanske Leviduru bilobatus el en fuldkommen ligesaa stor Tel at Troppen ubedakket af liygrajoldet som hos Amus cuncriformis. Man kjender 6 ellev 7 furskjellige Arter af denne S'lagt, livorat' liun en tilhorer Norges Fauna.

\section{Lepidurus glacialis (kroyer).}

\author{
Pl. NI, XII, NIII)
}

Apus ylaciatis, Kroyer', Nat. 'Tirisskr. 2 R. Bd. 2, p. 481.

Lepidurus glacialis, Packard, Monogr. Phyll. Crust. North Ame. rica. U. St. Geol. Surv, I, P. :iJ6, P. XVI, I'l, XYII, figs. $1-5$, Pl. IJI. fius. I, 2.

Artscharacter. - lirgskjoldet af millelmaalig sitorelse, bredt oralt, jernt afrunctet tortil, med en traleligt markeret dorsal Tijol; det bagre Tndsnit tenmelig dybt, vinlielformigt. 12-1s Segmenter uluedakliede bag Rygskjoldet. Halepladen forholdsvis meget kort, i Regelen ikla liengere end sidste Hale segment er bredt, tungetormig, neple indsnoret ved Basis, undertiden svagt ind lianlet i spidsen, Tanterne uned et begrendset Antal Sagtakkel. 2det Par Folere tilstede som sma Rulimenter. 1ste Fodpar mea Enditerne meget korte, kum mbetrleligt overragende kianterne af Rygskjoldet. Farren hos levende Exemplarer mere eller mindre mork olivenhrm. pas spiritusexemplarer enstormig gron. Laenglen at Humen indtil of mm, af Hannen nwpe mere and 1:3 mm.

Bemærkninger. -- Niprerende Art el forst kortelig beskreven paa ovenumforte sted at hroyer,

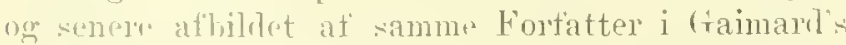
store Risiserate, dog lier men nogen Peskrivelse. Hon adskiller vig fra de wrige Arter at Slægten. og naxulig fru den i Mellenunupa almindeligt forekomnonde Lopiturus promuchs, ved Rygskjolilets ringede Stronelse, do moget linte Enditer paa 1ste Fodpar, ug ved Halophalesus Ririthed. lesperts exartly with those of $A$ mos, both in external habitus and in anatomical details, it may be questioned whetliel these two genera can in reality always he liept distinot from one another. Fur instance, it will be found that the length of the emlites in the first pail of legs in the genus Lepidurns, varies not a little; and the caudal lamella, at any rate in cer tain species, is so greatly reduced in size as to be almost rudimentary. The carapace is vertainly generally larger in Lepidurus than in tpus, and therefore covers, in the former genus, a larger part of the body than in the latter: lut it will still be tonnd that even in this respect there is consinerable valiation in the species of both genera. For instance, in Lepinturus glacialis it is scarcely larger than in $A_{\nu}$ s concriformis, and in the North Ameriuan Lepidurus bilobotus, finlly as large a part of the boly is left murever by the carapace as in Apus cancriformis. six or seven different species of this genus are known, only one of which belongs to the fauna of Norway.

\section{Lepidurus glacialis (Kroyel).}

(Pl. XI, XII, XIII).

Apue glucialis, Lroyer, Nat. Tidsekt. 2 R., Bul. 2, J. 431.

Lepindures glecialis, Packard, Nonogr. Phyll. Crust. Forth America. [C. St. Geol. Surv. I, p. 316, P]. XVI, P]. AVIl, figs. $1-5, \mathrm{Pl}$.X.1, figs, 1,2

Specific Characters. - Carapace of medim size, broadly oval, erenly rounded in tront, with a distinctly-marked dorsal lieel; posterior emargination rather deep and angular. From 12 to 18 of the posterior segment = not covered by the caraprace. Caudal lamella compratively very shrt, generally not longer than the breadth of the last raudal seg ment, linguiform, suarely constricted at the base, and somptimes slightly notched at the extremity: alges with a limited number of denticles. Serond pail ot antenne present as small rudiments. First pair of legs with the endites very short, projecting only slightly bevond the elges of the rarajace. ("olon in living spexmens more ol less dark olive brown, in sirit specimens, miform green. Length of the temale up to $24 \mathrm{~mm}$, of the male, scarrely more than 1:2 mm.

Remarks. - The present species was first briefly described in the above-named paper, by Froyer, and subseruently tigured hy the same anthor in Gai marl's speat work, but without any lescription. It dittips from the other species of the genus, and pspecially form Lepiturus profuctus, so common in Central Enrope, by the smaller size of the carapace, the very shont endites of the first pail of legs, and the shortness of the raudal lamella. 


\section{Beskrivelse af Humell.}

Langden af de storste af mig nnder'sogte Ex"mpilarer" er', maalt fia Panderanden til Enden af Halepharlen, $2 \pm \mathrm{mm}$. Dog synes det at være meget sjeldent, at den naar en saa betydelig storrelse. og $18-20 \mathrm{~mm}$. maa ansees for Gijmensnitsstorrelsen for fuld ndviklede Individer.

Som hor de ovrige til denne l'lyyllopmlegrmpue horende Former, er (se Tab. XI, Fig. 1) Storsteparten af legemet dakket opentil af et bredt, kun svagt luvelvet Rygskjold, hvorverl legemsfirmen faar et nuget Hadtrykt Edseende. Inette livgskjuld el" fortil fuldkommen sammenvoxet med Hovedet, hvorimod det bagtil liun lost dxkker den underliggende Trop, som frit kan bevæges nuder samme (se Fig. :3). Sees Legemet oventra (Fig 1, viser sig en storre eller mindre Del af Kroppen at rage frem bagenfor Rrgskjoidet $\mathrm{i}$ Form af en jernt af'smalnende, noget rrlindrisk Hale, endende med 2 lange, divergerende Tedhæng: Haletraatlene, mellem livilke destuden rager frem en liden median Hateplade. Sees Legenet nedentra (Fig. '), ligger hele Dyrets Bugtlade med sine forskjellige Vedliæng firit for Beskneren indentor Rygskjoldets Conmritet. Helt fortil sees en fra Panderanten ndgarende lablumaneformig glat Flade, uniddelbart bag livilken Fuleme og Munddelene har sin Plads. Trerpaa folger den lange Rakke af Fodder, der viser et temmelig nensartet Udseende. Iste Par er ialmindelighed lige uclstrakt til hrer side, saa at det noget overrager Siderandene af liygskjuldet, medens de lerpraa folgende 10 Par er mere indadkrummede. $10 \mathrm{~g}$ saalecles, at cler mellem dem i Regelen altid fincles et aabent Rum, i Bunden af livilket Kroppens Bugside sees i Form af en smal rendeformig Fordrhning, begræudset til Siderne af de respective Fodder's indadretterle coxallapper. Liengere bagtil indsnevres dette Rum, og Fouderne ligger ber tiet sammen som Bladene i en Bog, aftagende gradvis i Storrelse. Den samlede Fudnasse antager derved Formen at en bagtil vendende spicls Kegle. Den bagerste Del af Legemet pr uhen lemmer og af simpel cylindrisk form.

Rrgskjoldet viser, ovenfira seet Fig. 1), en lredt wal Form, merl Sidekanterne jevnt bnede og fortil gaaende $\mathrm{i}$ et med den ligeledes buede Frontalrand af Hoverlet. Bagtil er det noget indsnarret og har i Hidten et dylit, vinkel formigt hndsnit, hvis Kanter er beviplnede med sma spidse Tagger. Oventil sees $\mathrm{i}$ den forreste Del en tydelig transversal Fordyluning, Nakkefuren, i Bunden af hvilken der er en afrundet Tværvulst, der antyder Mandilmlarsegmentet. Den foran Nakkefuren liggende Del reprasenterer Hovedet, der i Midten viser en stumpit afrunlet lorhoining, pan hvilken de 2 sammensatte bine

\section{Description of the Female.}

The lengtl of the largest specimen examined by me measured $24 \mathrm{~mm}$. from the firontal margin tu the end of the caulal lamella. It seems, however, very seldom that it attains so consideralie a size, and from 18 to 20 mm. must be omsidererl as the average size for fully-developer animals

As in the wher forms belonging to this gromp of Plyllopoda, the greater prart of the borly sep Pl. XI, fig. 1) is coreled above by a broad, only slightly vanlted warape, whereby the boty arfuires a somewhat Hattened appearance. This rarapare is completely united in front with the heal, whereas posteriorly it only loosely cover's the mulerlying borly, which can more freely beneath it (ser tig. :3). Then the animal is viewed from above (fig. 1), more or less of the borly is seen projecting from behind the carapace in the from of an evenly tapering, somewhat cylindrical tail, ending in two long, divergent appendages, the candal filaments, between which there also projects a small median candal lamella. When viewed from below (fig. 2), the whole of the animal's rentral surface with its various appendages lies exposed to view within the encavity of the rarapace. Right in fremt, a "resuent-shaped, smooth surfare is visible, starting from the frontal margin, and immediately helind this are situated the antennæ and the oral parts. Then follows the long row of legs which present a somewhat heterogeneons appearance. The tirst pair is generally extended equaliy to luoth silles, so that it projerts a little beyond the lateral edges of the ralaparee, while the following io pairs are more bent inwards. though in sueh a way, that, as a rule, there is an open space between them, at the bottom ot which the rentral surfice of the loody is visible in the shape of a narrow grove bounded laterally by the inwardly inclined coxal lobes of the respective legs. Fnther bark, this space is rontracted, and the legs lie as close together as leaves in a book, diminishing gradually in size. The arcummiated mass of leg's then assumes the torm of a posteriorly pointing cone. The hindmost part of the body is withont limbs, and in the form of a simple "rlinder.

The caralace, seen from abrre (fig: 1), is of a brnad oval shape with the lateral edges evenly curved, and continuous with the likewise surved frontal margin of the heal. It is somewhat narrowed behind, and has, in the middle, a deep, angnlar incision, the edges of which are armed with small, sharp denticles. In the anterion part alore, may be sen a distinct transversal hollow, the cervical sulnos, at the bottom of which there is a rounded transverse prominence, indicating the mandilutar segment. The region in front of the cervical furrow represents the head, and exhihits, in the centre, a bluntly 
har sin Plark. Bag Nakkefinen begrucler den frie Del af Rrgsijoldet, lel sum en Kappe lost bedrkker den underliggende Krur. Treme Del har efter Midten en trilelig Kjol, rler bliver mere fremtrarende lagtil, hrom rlen ender med et spidst Frem. spring i Bunden af lirgskjulilets bagre Indsnit. Fortil pr, som orentor antort, liygsijoldet fuldkrommen sammentroxet mel Hovedet og danner her nedentil (se Fig. 2) on halrmaanufumig horizontal I) thplicatm; hrorved Hoverlet far en udpreget, bredt. sorlitannet Form (se ogua lig. :3). Hrad angar lirgskoldets finere Prgning, saa mangler det ethvert s jor at Kalkatleinger og er dertor meget hoieligt on idethele af en temmelig lingl Consistens. Det er, som sadvanligt, sammensat af 2 Lameller, en rilue meget trond, fuldkommen glat og glimisende Lamelle af chitinos Besliaftenhed, $1 \mathrm{~g}$ en indre memhranos og noget sjongios Lamelle. Mellem begroe findes et ristem af Hulrum, hrori Blodet irkulerer, "g desnden de I muget starkt moriklede Skallijertler. Irisese er delvis ndvendigt synlige som aflangt ovale, noget sabeltormigt krmmmede Felter, der fra Takkefuren strakker sig langs ad Sideme af den frie Irel at Rrgskjolilet se Fig. 3). Te be star hror (se Tals. N1ll, Fig. 4) at en Here (tange syngeformigt bugtet Kanal, der sunes at nimunde verl Basis at hindbakkerne.

Borttager man len trie Jel af lirgskjoldet, sees (Tal. XIII, Fig. 1 og :2) den molerliggende Krop at viere rlelt i en Pixklie meget ensformige Segmenter, lev iklie numperer sig til troleligt markerede Afsnit, om det end eftel. Fonlolidet af Lemnerne lader sig giore med nogenlunde Sikkerherl at luestemme fripudserne for de 3 sadvanlige Kropsafsnit: Midt krop, Paglipop og Hale. Negmenternes Antal er ialt 23. Heraf tilhorer de 11 torste Midtkropen og biter hrert et enkelt ]'ar Fodder, hrorimol de 11 tolgende, til Bagkioppen Inmende Segmenter bærer livert Here Par Forder. le 6 bagerste segmenter * follose og reprasenterer derfor len egentlige Hale. De er meget karpt liegrandsede, merl Bagkanten nuget haret og lmudt om bevabnet med liorte Tagger, der ogsaa forefinder paa Rrgsiden af cle namest tilgrandsende Segmenter af det fore. warenkle Afsnit. Nidste Halesegment se Tab. XII, Fig. ug har oventil paa hrer Sile af Midtlimien en rundagtig Knule besat med en Kruls at suaa Tagrer. $i$ hris Midte en fin Siandselurste sees at rage frem

loig. 2x. Ted Enden af Segmentet findes paa den rentrale Side Analadbningen, og nmiddelbart over leme tortsutter Siegmentet sig $i$ en trond ho. lizontal Plade, des skriler frem bagtil mellem Basis at rle - Haletraade. rounderl prominence, upon whith the "2 rompomm eyes are situated. Behind the cervical furrow, the free portion of the carapace begins, covering lousely, like a mantle, the underlying ludy. Down the centre of this part, threpe is a clistimet keel, whirh becomes more jrominent posteriorly, and ends in a sharp projection at the hrottom of the posterior emargination of the carapare. As staterl above, the carapace is completely roalescert in font with the head, and there forms, below (see fig -2), a crescent-shaped horizontal duplicatnre, whereby the hearl acruires a pronomnced shorel like shape see also fig. 3). With regard to the finer structure of the carapace, no trace whatever of calcareous deposit is fommd in it, ambl it is therefore very Hexible and, on the whole, of a rather soft consistence. It is, as nsmal, composed of two lamellæ, one extemal, very thin, jelfertly smooth and shining, and of a rhitinous nature, the other, an imner. membranoms and somewhat spongy lamella. Between the two there is a system of ravities, through whiol the blood cirmbates, and also 2 very highly developed shell glands. These are partially visible externally in the form of long oval, rather ensiformly rurved areas, extending from the relvical sulcus along the sides of the free portion of the carapace (see fig. 3) They each ronsist (see Pl. XIII, fig. 4) of a tube with sereral windings, whirh seems to open at the base of the mandibles.

If the free portion of the carapace be removed (1'. Xlll. figs 1, 2), the underlying borly is found to be divided into a series of rery unifom segments, which of not apportion themselves into rlistinctly marked sections, although it is possible, by the rela. tions of the limbs to one another to determine, witl a measure of certainty, the limits of the 3 ordinary divisions of the hody, - the mesosome, the matasome and the tail. The nmmber of the segments $j$ 28 in all. Of these the first 11 belong to the mesosome, and pach wry one pair uf legs, whereas the tollowing 11 regments, which helong to the metasome, parli cary sereral pairs of legs. The last 6 segments have no legs, and therefore represent the tail proper. They are very sharply defined, the pusterior edge being somewhat raised, and armed all round with short lenticles, which are also found on the dorsal side of the adjarent segments of the prereding sertion. The last raudal segment fsee Pl. XII, tig. 23-27) is ather longer than the preceling ones. and has above. on parth side of the median line. a romud prominente surrounderl br a cirrle ot small dentives from the milst ot which a tine sensory bristle is seen to project (see tig. 2o). At tho end at the segment. on the ventral side. is tle anal orifice, and immediately above it, the segment is juolonger into at thin horizontal lamella, jrotru- 
Deme Plade, rer er" eiendommelig for slagten Lepidurus. "r hus nærværende Art ialmindelighed at forhullsris ringe Storrelse ug som oftent ikke lipnger end sidste Halesegment er lredt. Formen er mere eller mindre ndpraget tungerlannet, nden nogen hemprkelig Influnoring verl Basis. Den varierer forovrigt serdeles meget saavel i itorrelse som form, Juvad der vil kiunne sees af de her givne Figurer (Fig. 23-27), og tiltager ialmindelighed i Længde med Alderen. Fig. wo tremstiller Halepladen hos et sanske usadvaulig stort Exemplar. Det er imidlertid meget sjeldent, at den nan en saa betrdelig Storrelse sum her angivet. Langs plter Milten har Haleplaren hos alle Indirider en stump Kjol besat merl et noget varierende Antal af grove Tagger, sedranligris 2 eller 3 . Kanterne el $\mathrm{i}$ sin ydre [o] grovt og noget nregrelmasigt sagtakkede. Hos de Heste Exemplarer har Spidsen af Halepladen et lidet. Indsnit i Tirlten, hrorved dannes 2 korte Enrlelapper, der ofte er astmetriske (se Fig. ㄴ.

Te sammensatte Oine har, som ovenfur anfort, sin Pladk paa den mest tremragende [Del at Hoverlets

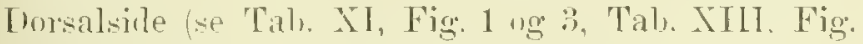
$10 g$ 2). Le er, i Modsetning til hyad Tilfoldet hos Branchipodiderne, sessile, at nrredamet Form, ug saaledes stilledle, at dcres Forende ligger nrex sammen, medens der bagtil mellem dem er et storre linm, der inclages af et ovalt, nuget ophoiet $\mathrm{og}$ skarpt legrapudset Felt. den saakalite Pusturularkunde (Tal. XuI, Fig. 1, x, Fig. 8). Lmiddellart foran de sammensatte Oine ligges det enkle Oip (Fig. 1, 5, oc), som dog ialmindelighed km ntỵleligt skinner igiennem Integmmenterne. Hral de sammenxatte Oines hygning angaar, saa stemmer denne idethele. naas afsees fra deres sescile Character, wverens med samme los Branchipodiderne, skjondt "gowa risse Unrerensstemmelser kan paarises Fra let morkebrune Pigment sees talrige starkt lyshrydende Legemer at straale nd til alle Siler. Disse Legemer er den rdre Tel af Krystalkeglerne, hvis indre spidst ultrukne Del ar dybt indplantet i Pigmentet. Enhver Krystalkegle viser sig ved nærmere Underogralse (Fig. 6,7 ) at vare sammensat af 4 Lrengdesegmenter og forbinder sig indad med den twærstribede Srnstar, lwortil igjen slntter sig en af de mange Endefilore, livori Srusnerren oploser sig. Ethrert sinselement el isoleret verl en memJranus skede, i hris Mlidte sees 2 tydelige, jernsides liggende Kjerner (Fig. i).

Fonste Par Folere (Tab. X11, Fig. 1, a ", Fig. 2) udspringer gra Hovedets Ventralside til hrer side af Urerlæbens Basis og umidrlelbart bag den halymaaneformige Pandeduplieatur. De er meget smaa og ialmindeligherl retterle skraat ulad og fortil, idet de boier sig om Bagkanten af den ovemnernte ding posterinly between the bases of the "andil tilaments.

This lamella, which is pernliar to the gemus Lepidurus. is genorally; in the prosent speries, of comparatively small size, measuring as a rule nu more in length than the last caulal segment does in breath. The shape is more or lese deciderly linguiform, withont any noticeable constriction at the base. It also varies very mull both in rize and shape, ats will be seen from the figures here given (figs $23-27$ ), and generally increases in length with age. Fig. 25 represents the caudal lamella of an mosmally large sperimen; but it is rery sellom that it attains to su considerable a siz" as that lrere shown. The rautal lamella in all suerimens has merlially a blunt lieed armed with a rather varjable number of roalse denticles, generally 20 of 3. The erlges are cuarsely and rather irregularly dentated in their onter portion. In most suecimens there is a small indentation in the middle of the extremity of the cantal lamella, thus forming 2 shont, terminal, often asymmetrical bubes (see fig. '2i)

The romponnil eves, as alores stated, are situated on the most prominent part of the dorsal sur face of the hearl (see Pl. XI, fig.t. 1, 3; Pl. XllI figs. 1. 2. Inlike those in the Branchipodina, they are sessile, reniform in shape, and so placed that their anterion ends lie close together, while betwren them posterionly there is a consideralule space which is ocenpied by an oval. somewhat elevated and sharply-defined fiekd, the sorralled post-ornlar tubercle (PI. XIll, tig. $1 \mathrm{x}$, fig. \&). Immediately in front of

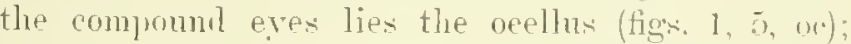
which, howerer, is generally only indistinctly spen throngh the integments. With regarl to their. strueture, the rompond eyes, setting aside their sessile chararter, agree with those in Branchipodidie, thongh a few printe of ditference can he tomul. Numerous strongly refractive hodips are spen ralliating to all siles from the dark lnown pigment. These bonlies are the onter part ot the rystalline cones, the immer pointed part being huried deeply in the pigment. Farh errstalline cone proves, on it closer examination (tigs. (i, 7), to loe composed of 4 longitudinal segments, and to commert itself interiorly with the transeresely bared nenlar ror to which, again, wre of the numerons terminal tibres. into which the optir nerve resolves itself, is attached. Each risual element is isolated in a membranous sheath, in the middle of which are seen "distinct molei lying side by side (tig. 7 ).

The first prair of antenna (1'l. XII, fig. 1, $a^{2}$, tig. 2) spring firm the rentral surfacr of the liear om each side of the base of the mpper lip, and immediately liehind the rescent-shaped frontal duplicature. They are very small, and are generally directed oblipguely cutwards and forwarls, bending 
Dupliratnr. Man kan paa dem adkikille et smalt, af en bel ntrileligt somdrede Led hestanende Slaft $o g$ en nriget opsrumet, aflangt tenformig Enderlel. Ireme sidste ender med 3 liorte Foleborster og har lang. sin nedre Side talrige smaa Lugtepapiller, ordnete i flere Riskker (se Fig. 3). Enhver af disse Longtepapiller (Fig. t) riser sig red stark Forstorrelse at udspringe med en liort og tynd Stilk og har let rdre l'arti skjievt udvidet, lannende en stmmp, Tinkel med stillien. De ender i en stumy sprids, i hris indre en liden stærlit lysbrydende Blære har sin l'lats.

Anclet Par Folele (Tals. XII. Fig. 1 a ${ }^{2}$, Tab. XIIl, Fig. 2, a ${ }^{2}$, der udspringer tret red 1ste Par, og lidt længere udad, er blot tilsterle som rderlig sma liudimenter, rler er noget forskjelligt ndviklede hos forskjellige Individer (se Tab. XII. Fig. $5,6,7$ ). lalmindelighed danner de liver et smalt, $i$ en tynd spids ndgaaende Appendix, paa hrilliet undertiden kan adskilles en noget tykkere Basaldel og en tentakelformig Endedel. Hos pt Exemplar var Spidsen ulige trekloftet (Fig. 6).

Af Munddelene er Overlielien og Kindlakkerne let lopmarkelige, horimod de derjaa tolgende Dile er mere eller mindre tinldstirndig skinlte af Orerleben, saa at man kun ved Dissection kan faa liede paa deres Bygming.

Overlaben (Tah, XlI, Fig. 1, I, Tal, XIlI, Fig. 2, L) udspringer fra Midten af Pandeduplicaturen, med hvilken den er lievægeligt forlounden, saa at den til en vis Grar kan loftes op fra de orrige Dunddele. Talmindelighed ligger den dog tart ind mul hindbakkerne, drkkende en stome Del af samme (se Tab. XI, Fig. 2). Then er at forlolderis betydelig storrelse ong viser en afrundet firkantet Form, med den medre Flade sragt convex, den ovre noget commareret. Enderanden er sragt ndrandet i Nidten og meget fint cilieret

Kindbakkerne er megret lisaftigt udviklede rig hos det roxue lyre uden ethvert spor af nogen Palpe. Ileres ydre Del er meget ioinefaldende, naar brret sees fra Bugsiden (Tat). Xl. Fig. 2), og riser sig som en pratrors oral Furlooining til hrer side at (trerleben. Irerimol skjules deres indre Tel, Tyggerlelem, ganske af 0xerlaben og kommer forst tilsrne, naar denne loortfjernes eller loftes op (Tab. XII. Fig. ], XI Det orale, baadformige conpus ise Fig s er med sin ritre, i an spids ndgaaenle Ende articnleret til Indsilen af Mandibularsegmentet og har den indre Hule frldt med de liratige AdilurtorMnskin'. Tygardelen el strulst. næsten oxeformigt udridut. og delt i $i$ kraftige. trekloftede Truder, hivenat den bagerste eller valerste er den storste og ved ef stmipe Melleminm skilt fra de urrige der successivt aftager $\mathrm{i}$ itorrelse. Hen inderste Tand romal the pusterior margin of the above-named dnplicature. A narmow scape, ennisting of some indistinetly articulated joints may be distinguisherl, and a rather swollen, oblong-fusiform terminal part. The latter emls in 3 short sensory bristles, and, along its lower side, has numerous small olfartory papilla, arrangerl in several rows (see fig. 3). Eaeh of these olfactory pajille appears, when highly magnified, to stand on a thin, short stalk (fig. 4), while the distal part is oblingely expanded and forms an ribtnse angle with the talk. They end in a blunt point, inside whieh a small, strongly refiactive resiole is found.

The serond pair wf antennæ (Pl. XII, Hg. 1, a*; 1']. XIII, fig. "2, $a^{2}$ ), which spring unt rlose to the first pair, and a little farther contwards, are only present as exreedingly small ruliments, which are developerl differently in different sperimens (see Pl. XII, figs. 5, 6, 7). 'They generally early form a thin, tinely-pinter aplendage, in which may sometimes be distinguisherl a thirkish hasal part, and a tentacnlar terminal part. In me specimen, the pwint was mnequally bifid (tig. (i).

of the oral parts, the labrum and the mandihles are easily distinguished. whereas the suceeding parts are more or less encealed ly the lahrum, so that any linowledge of their structure is only to be obtained by dissection.

The labrum (Pl. XIl, fig. 1, L: Pl. XIII, fig. 2, L) issues from the middle of the trontal duplicature, with which it is movally comected, so that it can, to a rertain extent, be raiser from the other parts. It generally, lowerer, lies inse in to the mandibles, covering the greater part ot them (wee Pl. XI, fig. 2 It is of eomparatively large size, amd presents a monded quadrilateral slape, with the lower surface somewhat convex. The dixtal edge is slightly emarginated in the middle, and rery finely riliated.

The mandilsles are rery powertully dereloped, and, in the full-grown animal, possess no trace of palpi. Their onter part is rery ronspicuons in a ventral aspect ot the animal (PI. XI, fig. 2), and appears as a transverse oval prominence on each side of the labrum. Their inner, masticatory jart, on the other land. is inite hidilen by the labrum, and is only risible when the latter is either removed or raised (I'l. XII, fig. 1, M). The oral, narisular borly (see fig. is) is artieulated by its puinted distal end to the inside of the mandibular segment, its inner cavity being filled by the powerful addurtor muscles. The mastiratory part is greatly, alunost securiformly expanded, and divided into 8 powerful, bitisl teeth, the hindmost an ontermost of whieh is the largest, and is separated by a greater space from the other's, which smeresively decrease in size. 
er utrdeligt tredelt og har $\mathrm{i}$ den indre Kant en fin Ciliering (Fig. 9).

Bag Kindbakkerme folger nu tiet sammen de wrige Mnuddele (se Tab. XII, Fig. 1), som det ikke er saa ganske let at isolere, da de delvis er forbundne red et Srstem at stapke Chitinlister. Imidlertid er det ilke saa vanslieligt at parrise, at de damner :3 paa hinanden folgende Rxkker: forrest en vel ndviklet Underlabe, derefter 2 Par normalt udvilitede Kijever.

Unterlæben (Fig. 10, 1, Fig. 11) hestaar af 2 srmetriske Halrdele eller Lappe, forbundne i Nidten vel en tynd Membran. Enliver Sirlelap er stottet af en nogret bueformig Chitimplade, der ved Basis hænger sammen ned den tilsvarenle forreste Kijæve (se Fig. 10), og hvis Endle damer en smalt afrundet indboiet Lob besat med tatte Haar. Indad fortsatter ('hitinpladen sig i en tyrndere, lualvt membranos Lamelle, der ligeledes er fint lasuet $\mathrm{j}$ den indre Kant og langere bagtil har et tat trastribet marginalt Parti. Af andre Forskcre er Underlabens Sirlelappe tydede som 1ste Kjavepar, hvad der aabenbart er migtigt, da disse lappe er fuldstandig uberægelige og desuden forbundne i Midten ved en tydelig Membran. Mrrkelig er iethvertfald hos nærvarende Guppe Tilstedevarelsen af en vel udviklet Underlabe, som hos de hoiere Crustafeer. Thi luos andre Pliyllopoler, ligesom ogsaa hos den store Fle1hed af Entomostraceer, sees neppe en Antrdning til demne Del.

1ste Par Kiaver (Fig. $10 \mathrm{~m}^{1}$, Fig. 12) damer hver en i Enden axeformigt ndvidet Chitinplarle, den med sin tilspidsede Basis er forbunden med Under. læbens ('hitinskelet, og derfor red Dissection ialmindelighed fares i Sammenlæng med Underlæben. Paa Grund af Chitinsubstantsens Elasticitet kan de imidlertid til en vis Grad hevages imod hinanden, og en Del tydelige Mnskler, der lober skraat indad, besorner denne enkle Beragelse. Paa den oxeformigt ndvidede indre Ende er de beræbnede med talrige korte Pigge og en liel Del stive Borster. let forreste Hjorne damer en sarskilt, noget paatrært stillet Lap, som er forsynet merl en Del noget starkere Pigge.

2det Par Kjever (Fig. 1, m², Fig. 13), der af andre Forskere (Packard) feilagtigt el tydede som et Slags Kjovefodiler, er af nere membranos Beskatfenhed og ender indad med en afmulet, tmingeformig Trgela], besat merl talrige grovt cilierede Borstex. Paa den rilre side tindes en stumpt conisk Udvidning af en noget lignende spungios Beskaffenhed son Fordernes Epipoditer. Denne Udvidning maa næmest opfattes som et Slag's rudimentær ralpe.

Fodderne er, som ovenfor navnt, overordentlig talrige, idet der paa den bagre Del af Truncus (Metasome) findes mange flere Fodpar end der er
The innermost tootl is faintly tripartite, and is finely ciliated on its inner' edge (fig. 9).

'The remainler of' the oral parts now tollow closely behind the mandibles (see Pl. XII, tig. 1), and are not very sisy to separate from one ano. ther, being pratially connecterl by a srstem of strong chitinoms fillets. It is not, howerer, difficult to see that they torm 3 consecutive series: in front, a rrell-dereloped interior lip, and then 2) pairs of normallv-rleveloped maxilla.

The inferior lip (tigs. 10, l, 11) consists of 2 sym. metrioal halres or luhes, comnected in the midlle by a thin membrane. Each lobe is supported by a somewhat arehed ehitinons lamella which is mited at the base to the eorresponding anterior maxilla (see fig. 10), and whose end forms a nar'owly romuled, incurved, thickly ciliated lobe. The chitinons lamella is continned inwards in the form of a thimner, half-membranons lamina also finely ciliated on the inner elge, and whose marginal part, farther back, is thickly barred transversely. The lateral lobes of the luwer lip are designated by other naturalists as the first pair of maxilla, but this is clearly iucorrect, as these lobes are quite immo vable, and are connected in the midclle by a distinct membrane. The presence, in this group, of a well developed inferior lip, as in the higher Crustacea is, at all events, remarkable; for in other Phyllo poda, as also in the majority of Entonostraca, there is scarcely an indication of this part.

Each of the first pair of maxilla (figs. $10 \mathrm{~m}^{1}$, fig. 12) has the form of a securitormly expander chitinom: lamella, which is connected by its pointed base with the clitine slieleton ot the interior lip, and is therefore, when dissected. generally detacher in onjumetion with that part. On arcount of the elasticity of the chitine howerer, they can, to a certain extent, be moved towards one another, and several distinct muscles, ruming obliquely inwarts, effect this simple movement. On the securiformly expanded inner end, the maxillæ are armed with numeroms short spines, and a number of stiff luistles. The foremost cormer is in the form of a peculiar, somewhat obliquely placed lobe, fmonished with a few stronger spines.

The second pair of maxillæ (fig. $1 \mathrm{~m}^{2}$, fig. 13) which hare been incorrecty interpreted by other naturalists (Packarl) as a sort of maxilliped, are of a more membranous nature, and terminate insid, with a rounled lingnifom mastioatory lobe, clothed with numerons coarsely riliated bristles. On the onter side, there is a bluntly conical expansion of a spongy matne, somewhat similar to that of the epipodites of the legs. This expansion should probably be regarderl as a sort of rudimentary palp.

The legs, as stated above, are remarkably nmmerons, there being on the posterior part of the trmuk (the metasome), many more pairs of legs 
Segmenter. Paa Midtkroppen Jorer derimod livert Fegment kun et enkelt Par Foulder, og ile er her ogsaa langt kraftigere udviklede (see Tab. NI, Fig 2), visende idethele, naar undtages 1ste Par, Characteren af agte Griberedkaber, rel skikliede til at gribe og fastholde den Naring, livoraf Drret lever. Fororrigt er disse torreste Par, ligesaavel som de lagerste, forsrnede med do 2 characteristiske rdre Tedhang. Exoporlit og Epiporlit, der begge symes at sta i Resprimationens Tjeneste. Foudernes Antal er ialt ikke mindre end (ia) Par.

1ste Fodpar (Tah. XII, Fig. 1, p ${ }^{1}$. Fig. 1t) sliiller sig kjendeligt i sit Ldseende fra de folgende Par, og el ngsaa ialmindelighed mere udadrettede, saa at de delvis overrager Rrgskjolktets sidekanter. De bestaar imidlertid af lo samme Hoveddele som de orrige Foduler. Sielve Stanmen viser en mere eller minche trolelig Segmentering. Narmlig er der paa Midten af samme en meget listinst Ledfoining, der deler Stammen i en indre og en wdre Del, dammende med hinauden en noget knæformig Boining. Den indre Del af Stammen lar, som paa de ovrige Fouller, ved Basis en rel udviklet og meget skarpt sondret Coxallap, der er rettet lige indad og besat paa sin stumpt afmulede Ende med talrige korte Pigne og fine, indalkmmmede Borster. Af de saakaldte Enditer er liun den inderste frestet til demne Del af stammen. merlens le 3 orrige ulgaar fra dens ydre Atsuit. We har alle Formen af forholdsvis smale, nasten traaltomige Fortsatser, grovt sagtakkele $i$ Kanterne $o g$ delvis visende en ntydelig Leddeling. Den tde eller rderste Endit er doblrelt sa lang som den lste og omtrent af Stammens halve Lixngde. Tod liasis at denne Endit er der et ubetyleligt lancettormigt Fremspring, der repræsenterer lindimentet af den paa de ovige Fodpar meget krattigt udviklede 5te Eudit. De - rodre Tedhang el begge forloldsvis smaa. Epipoditen (ep) har Formen af en afrumdet oval Lamelle, der ved en kort Stilk ar frestet til Stammens Tilerside omtrent ved dennes knaformige Boining. Exopoditen (ex), der udspringer i kort Afstand tra Epipoditen læugere udad, er ligeledes pladeformig, men betrdelig mindre og af nregelnassig trekantet Form, idet den er ulturuket i Flige, hvoraf den rlerste er mest fremspringende og rundt om kantet med fine Borster.

2det Forlpar (Fig. 15) er adskilligt stærkere bygget end 1ste, og skiller sig desurlen rasentlig red Furholuet af Enditerne. Disse er nemlig kortere og starkere, næsten klofomige, og mangler ethvert Spor af Leddeling, skjondt de viser i begge Kanter et Antal af smaa, merl fine Pigge besatte Afsatser. Den rderste eller 5̆te Endit, der paa 1ste Par kun than there are segments. On the mesosome, on the other liand, each segment carries only a single pair of legs, which are also much more powerfully developed (see Pl. IT, fig. 2), exhibiting. on the "whole, with the exception af' the first pair, the cluaracter of true grasping organs, well fitted for seizing and retaining the foud on which the animal lives. The anterior, as rell ax the posterior pairs, are furnished with the two characteristic external apjendages, exnpodite and epipodite, which both appear to serve as organs of respiration. The number of legs in all is no less than 63 pails.

The first pair of leg's PI. III, fig $1, p^{1}$, fig. 1t) is conspicnously distinguished in appearance from the sucreeding jairs, and is also generally directed more outwards, so as partially to project vrer the lateral edges of the carapace. These legs ronsist, however, ot the same principal prarts as the other legs. The stem itself shows a more or less ristinct segmentation. In the middle of it, notably, there is a very distinct articulation, dividing it into a proximal and a distal part, which form with each other a somewhat geniculated flexure. As in the other legs, there is, at the base of the joximal portion of the stem, a well-develnped and verr slarply defined coxal lube, directed straight inwards, and furnished at its bluntly romuled extremity with numprous short snines, and fine, incurved luristles. Of the soralled endites. onlr the immermost is attacher to this part of the stem, while the other 3 issue from its distal section. They all have the form of comparatively narrow, almost filiform processes, roarsely serrated at the edges, and partly slowing an indistinct segmentation. The fourth, or ontemonst endite is twice as long as the first, and about half the length of the stem. At its base, there is a lanceolate projection, which represents the rudiment of the powerfully developed óth endite on the other legs. The two outer appendages ar. Josth comparatively small. The epripolite (ep) is in the shape of a rounded oval lamella, attached by a short pedmole to the outer sicle of the stem at abont the geniculated bend. The exopodite (ex) which issues at a short distance from the epipodite, farther out, is also lamellar, but consirlerably smaller, and of an irregularly triangular shape, being llawn out into two lobes, of which the outer is the more prominent, and is edgerl all roumd with tine bristles.

The ond pair of legs (fig. 15) is far more strongly built than the first, and is, in other respects, principally distinguished by the relations of the endites to one another. These are shorter and stronger, almost claw-like, and devoid of everr trace of segmentation, although they exhibit at both edges a number of small serrations clothed with fine spinnles. 
var tilstede som et Rudiment, er lier meget strerkt udviklet, fuldkommen saa lang som den 4de, og udpræget kloformig. Den er i Yderkanten besat med fine Borster og har Inderkanten fint og regelmæssigt sagtakket. Coxallappen er noiagtig af samme Udseende som paa 1ste Par. Derimod er de \&̈ ydre Vellhreng, "g navnlig Exopoditen (ex) forholdsvis storre.

De folgende 7 Par gaar snceessivt over til at antage det Udseende, som 10de Fodpar viser. Dette sidste (Fig. 16) er idethele kortere og mere sammentræugt, mlen nogen tydelig Segmentering eller linæformig Boining af Stammen. Coxallappen er forholdsvis noget mindre end paa de e tomreste Par og mere lige indadrettet. Enditeme er kortere og bredere, niesten pladeformige, og den yilerste bredt lancetformig samt tæt borstebesat $\mathrm{i}$ den ydre Kant. De ydre Vedhang er begge af anselig Storrelse, og navnlig Exopnditen (ex) betyrlelig storre end paa de forreste Par; dens Form er ogsaa noget forskjellig, idet den er mere oval, merl den nerlre Flig bredt afrundet.

11te Fodpar (Fig. 17) viser et fra de ovrige Fodder meget afrigende Udseende, idet de 2 ydre Vedhæng her er omdannede paa en eiendommelig Maade, saa at de tilsammen danner en xskeformig Kapsel, hvori Eggene midlertiligt optages, for at forsynes med sin Skal. Laaget af Kapselen, der vender fortil og er af regelmæssig circular Form, dannes af Epipoditen, medens Bunden af Kapselen ndgjores af Exopoditen. Ogsaa deme er af tilmmdet Form, men noget bredere end Epipoditen, og udspringer med en bred Basis fra Stammen. Begge slutter temmelig noie sammen, dog saaledes, at der paa den ydre Side er en rendeformig Fordybuing, der dannes af de omboiede Kanter af Exopoditen. Selve stammen er kort og bred, plarleformig, $o g$ deu vderste Endit ikke tydeligt begrændset, dannende en umiddelhar Fortsettelse af Stammen i Form af en triangular Lap.

12te Fodpar (Fig. 18) viser igjen et mere normalt Udseende og stemmer idethele $i$ sin Bygning noie overens med 10de Par, naar unitages, at det er mindre og har den yderste Endit forholdsvis kortere $\mathrm{og}$ breclere. Det samme er ogsaa Tilfecldet med Exopoditen, hvis nedre Del er mindre tremspringende.

De folgende Fodpar aftager successivt i Storrelse og bliver tilsidst ganske rudimentre, skjondt alle de Dele, der findes paa de toregaaende Par, lader sig parise.

Fig. 19 fremstiller en Fod af et af de bagerste Par ved samme Forstorrelse som de foregaaende Par. Det vil sees, at Finditerne er betydeligt redu-
The ontermost, or 5th enlite, which in the first pair was only found as a rudiment, is here very strongly developed, is fnlly as long as the th, and of a pronounced claw-like shape. The onter edge is clothed with fine bristles, and the inner edge finely and legularly serrated. The coxal lobe is of exactly the same appearance as in the first pair. The two outer appendages, on the other hand, and especially the exopndite (ex), are comparatively larger,

Through the 7 snceeding pairs there is a gradual transition to the appearance of the 10th pair of legs. This pair (fig. 16) is on the whole shorter and more compact, without any distinct seg. mentation or geniculation ot the stem. The coxal lobe is relatively rather smaller than that in the foremost 2 yairs, and its direction is more directly inwarls. The endites are shorter and broader, al. most lamellar, the ontermost heing broadly lanceolate in form, and densely sptons on the distal edge. The onter appendages are both of considerable size, the exopodite (ex) especially being much larger than in the foremost pairs. Its shape is also somewhat different, being more oval, and the lower lobe more broadly rounded.

The 11th pair of legs (fig. 17) exhibits a very different appearance from the others, the onter appendages being transformed in a peculiar manner, so as together to form a hox-like capsule in which the ova are temporarily received in order to be furnished with their shell. The lid of the capsule, which turns to the front, and is of a regularly circular shape, is formed by the epipodite, while the bottom of the capsule consists of the exopodite. This, too, is of a rounderl furm, but rather liroater than the epipodite, and issues with a broad base from the stem. The two prarts fit together tolerably exactly, yet in such a manner that on the outer side there is a channel-like hollow formed by the decurved edges of the exopodite. The stem itself is short, broad and lamellar: the outermost endite is not clearly definerl, and forms a direct continuation of the stem in the shape of a triangular lobe.

The 12th pair of legs (fig: 18) exhibits a more normal appearance, and, on the whole, agrees rery nearly in its structure with the loth pair, excepting that it is smaller, and that the outermost endite is relatively shorter and broader. This is also the case with the exopolite, the lower part of which is less projecting.

The sncceeding pairs of legs decrease snccessively in size, and at last become quite rudmentary, althongh it is possible to distingnish all the parts that are foumd in the preceding pairs.

Fig. 19 represents a leg of one of the hindmost pairs magnitied with the same power as the preceding pairs. It will be seen that the endites are 
rerelle og starkere sammentrongte, og at ogsaa Epipoditen har aftaget sterlist i Storrelse. Derimod er Exopoditen endum forholdsis af ikle ribetydelig Storrelse og noget atrigende i Form, merl kun et begrændset Antal af Fandborster, livorat en ndmærker sig red betydelig Længde.

En Fod at silste l'ar er fremstillet Fig. 21 ved samme Forstorlelse som Fig. 1!), og Fig. 2-2 meget strerkere torstorret. Lagtet sin ringe Storlelse, har Forlen, sm det vil sees, alle sime Dele $i$ Behold, skjomlt i hoieste crad reducerede.

Haletradene (se Tab. Xl, Fig. 1-3, Tab. XIII, Fig. 1, 2), (ler naumest maa opfattes som et Slags. lemmer, og aabenbart svarer til Halegrenene eller Furca hos Tebatia og hos Bumchimortideme. el at meget betydelig laxngle, arkkilligt mere end halvt saa lange som liele legemet, og synes til en ris Grad at rare hevegelige, da de smat er starkt divergerende, snart mere lige hagudrettede. Ile udspringer til lrver Side at Halepladen, fra Enden af sidste Halesegment, og afsmahes gradvis mod Enden, der gaar ud $i$ en fin sijids. At C'onsistens ev de særieles elastiske, saa at de lader sig boie i alle Retuinger, men nogen egentlig Leddeling stnes ikke at rave tilstede. Tlerimor er de torswerle med talrige, noget skratgaaende 'Trarrader' at fine Pigge, som i den indre liant antager ('haracteren af fine Borster (se Tab. X11, Fig. 23-24).

Hannen ('Tab. XI, Fig. ‘), (; a) el betydelig mindre and Hunnes, intet den kmn opmaar en Langde af $13 \mathrm{~mm}$ og ligner ganske og alcleles unge Hunner af samme Storelse, uden at der er nogen ininetaldente secundare Kjonscharacterer at opdage. Det er dertor ikke saa let at kjende begge Kjon nd fra limanden, og dotte er vel for en Del Grunden til, at Hamner inden denne Gruppe sa volerlig sjelden or bleve observerente. Ted en noget noiere Tndersogelse, ex det dog meget let at bestemme Kjonnet efter 11te Fodpars Bygning. Hos Hannen er nemlig dette Fodpar (Tab. XIII, Fig. 20) ganske bygget paa samme Maade som de umiddelisat foregaaende og efterfolgende Par, medons los Hnmer af samme Stomelse den chararteristiske Askapsel allerede ex tydeligt ndviklet.

Farven er hos levende Fxemplarer af luegge Kjon paa Overwilen mere bller minlue mork olivenbrun, med et temmelig svagt grunligt skjar, og ofte fint spettet med gult og liselnunt. Tmiersiden af Rygskjoldet og Foulderues yole Terlhæung viser sædranligvis et roklmunt Skjar, og MImudelene har en mere eller minkle hombrum Farve. Efterat Drret nugren Tid har ligget paa Spiritus, gaar Farven iminlertid ovel til et temmelig enstormigt morkegront. considerably recheed and more compressed, and that the epipodite has also greatly diminisher in size. The exopodite, on the other hand, is still relatively of a considerable size, and differs somewhat in shape, having only a limited number of marginal luistles, one of which is remarkable for its great length.

One ot the last pair ot leg's is represented in fig. 21 magnified with the same porver as tig. 1!, and in tig. 2.) much more highly magnified. In spite of its insignificant size. the leg, as will be seen, has all its parts, though very greatly rednced.

The randal tilaments (see Pl. Xl. tigs. 1-ö; Pl. XII, figs. 1, 2) which must perhaps be considererl as a kind of limb, and evidently answer to the candal rami or furca in Nebatia and in the Branchipoctidre, are of very eomsiderable length, much longer than half the length of the hodr, and seem to be movalile to a certain extent, as at times they are widely divergent, at others directed more straight ont liehind. They issue, one on each side of the caudal lamella, from the end of the last randal segment, and tajer gradnally towards the timely-pointed extremity. Their consistence is exceedingly elastic, allowing of their being bent in all directions, Jnt there seems to he no actual articulation. They are furmisherl with mmerous rather oblipue, transverse noms of tine spines. which, on the inner ertge, assume the hararter of tine bristles (see Pl. XII, figs. $23,24)$.

The Male Pl. II, figr. 6. 6 a) is consileralily smaller than the female, and attains a length of only $1: 3 \mathrm{~mm}$. It exactly resembles young females of the same length, withont there being any comspicuons secondary sexnal characters. It is therefore not easy to distinguish one sex from the other, and this is prolably partly the reason why the males in this gronp have so very seldom been observed. (1) a closer examination, it is, however, very easy to determine the sex by the structme of the 11th pair of legs. In the males, the structure of this pail of lers (Pl. XIII, tig. 20) is the same as that of the pairs immediately preceding and following it; while in females of that size, the characteristir eggcapsule is alrearly distinctly develnped.

The colour in living sperimens of both sexes is of a more or less dark olive brown on the upper surface, with a slightly greenish tinge, and is often finely speckled with yellow and light brown. The muler surfare of the rarapace, and the wuter appendages of the legw generally exhilut a redish brom tinge, and the oral parts have a hom brown hue. After the animal has lain for some time in spirit, however, the colom changes to a toleralyly unitorm dark green. 


\section{Indre Oronner.}

Fordøielsessystemet. - Tarmen danner se Talb. XIII, Fig. 1, 2) et simpult rg temmelig vidt, hagtil noget afsmalnende Ror', der strakker sig igjennem Axen af Legemet, og udmunder, etterat have dannet en kort Endetarm, ver Enden at sidste Halesegment, muder Basis af Halepladen. Paa Tndersiden af dens forreste stmmpt afrundede Del numder spisermet, lev er starlit musculust og stiger loinet i Veiret fra Mnndabuningen. Dets ovre Ende suringer frit frem i Tarmens Tumen, og viser her en piendommelig kiajformig indretning se Tal. XII, Fig. 10, 11, (e), hrolved Tammens (ontenta hindres tra at passere tilbage ind i spiseroret. Med den firreste Del af Tamen forbinder sig et neget rompliceret leveragtigt Organ, ler fyller en stor Del af Hoverlet (se Tab. XIII, Fig. 1, 2, l). Det hestaa af 2 symetriske Halviele, hver delt i tahige nregel massigt forgrenede Blindsakke (Fig. 3), der er udklærlt indrendig med et Lag af glandulose ('eller. Alle disse Blindrakki samler sig tilsidst paa hrer side til en frolles kort Stamme, der munter i den torreste Del af Tarmen. Det hele Apparat srarer utvirlsomt til de 2 forholdsvis simple lindsaktormige Udridninger af Tamen hos Branchipodirerne.

Karsystemet. - Hjortet (Fig. 1, 2, (') er af meget langstrakt Form, og strækker sig igjemem hele Vidtkroppen, fra Mandilunlarsegment $o g$ ind $\mathrm{i}$ 11te fodbarende segment. Som salvanligt, ligger let umildelbart ind under Kroppens dorsale integmment, og afsmalnes gradvis torfil bagtil, hvor det synes at ende blindt. Fortil lar det rerimol en vid Aab. ning, hvorigjennem Blorlet drives ud i Hoverlet og derfia i rygskjollet og den ovrige Kroj). For hrert Kropssegment har det et Par venose Spaltex, forsynede med 2 klaptromige, bevagelige Laber, der afrexlenule lnkker og aalmex sig, og hrorimellem Blorlet optages $i$ Hjertet fra le torskjellige Dele af legemet. I Rygskjoldet finder en meget livlig Blor-ireulation sted, og Blotet giennemstrommer her et meget compliceret system af Hulrum, beliggende mellem de 2 Lameller, hroraf Ryssjoldet er sam mensat. Nogen virlielige Ploulkar existerer imillertid ligesaalidt her som los andre Phyllopoder.

Nervesystemet. - Som los andre Krebsilyr, bestar Nervesystemets Centraldele af let orie Sirlgganglion, eller Hjernegangliet, og an Puggangliekjarle. Hjernegangliet er meget vanskeligt at nndelsoge, da det ligger tirt omliyllet at' andre Dele. Saavidt jeg har kumnet se ved omhyggelig Dissection, er det (Tab. XIII, Fig. 5, g) torholdsvis lidet og af betydelig simplere Bygming end hos Branchipordiderne, uden de hos disse forekommende dorsale

\section{Internal Organs.}

Digestive system - The intestine see Pl. I1I1. figs. 1, 2) is in the form of a simple, rather wide tube, slightly tapering posterionly, and extending through the axis of the borly; after having formerl a short rectum, it opens at the end of the last candal segment lemeath the base ot the manlal lamella. On the miler side ot its anterior, l, luntlyrounded part, opens the oesophagus, which is exceelingly musenlar, and rises perpendicularly from the oral aperture. Its upper end projects treely into the lumen of the intestine, exhibiting there a pert. liar valve-like arrangement (see P'. XII, tigs. 10, 11, (e), wherely the contents of the intestine are prevented from passing back into thr (rsopliagns. With the foremost part of the intestine is romnected a very complicated hepaticous organ, whin necupies a great jut of the heal (see Pl. XIIl, hig's. 1, ‘, l). It comsists of 2 symmetrical halres, earl divicler into numerous irregularly ramitied ıæu (fig. 3), which are hined interiorly with a stratum of glandular cells. All these creca nnite at last, on each side, into a short common stem that opens into the anterior part of the intestine. The whole apparatus undonbtedly answers to the two "omparatively simple cocum-like expansions of the intestine in the Branchipodidie.

Vascular system. - The heart (fig. 1, 2, c) is of a very elongated shape, and extends thronghont the mesosmme, from the mandilnnlar segment into the 11 th podigerous segment. It lies, as usual, immediately below the dorsal integmment of the hody, and tajers grarlually from the tront to the back, where it seens to have no outlet. In fiont, on the contrary, it has a wirle opening, through which the blood is driven unt into the head, and thence into the carapace and the rest of the bucly. In each segment of the mesosome there are two venons ostia, each furmisherl with 2 valye-like movable lips, which alternately ojen and shut, and through which the lolood is receiver into the lieart firm the llifferent jarts of the hody. A repry active circulation takes place in the carapace, the blool Howing throngh a vert complicater system of cavities lying between the 2 lamelle of which the calapace is composed. Antual blond-vessels, howerer, no more exist here than in other Phyllopoda.

Nervous system. - As in other crustaceans, the central jortion of the nervons system consists of an npper usophageal ganglion, or cerebral ganglion, and a ventral gunglion chain. The cerebral ganglion is very difficult to examine, as it is closely enveloped by other parts. As tar as I have been able to see by careful dissertion, it is comparatively small (Pl. XII, fig. 5, g), and of a much simpler structure than in the Branchipodida, withont the dorsal lobes 
Lappe. Fra dets forreste Del ndgaar til hrer Side rig noget oparl en kort og trk Nervestamme, som er Śmsnerven. Efterat rape traadt hen mod den nedre Flade af Oiet, oploser den sig i tahige divergeremile Greue (se Fig. 7), hroraf hver enkelt for. binler sig merl et tilsvarende sirnselement. Fra Mirlten af Hjernegangliets formste Ende passerer en temmelig strerk Nervestamme lige fortil ng omgiver merl sin gangliost opsrulmede Ende det enkle Oie bagtil (se Fig. 5). Hvor Nerverne for Folerne ndspringer, bar det ilke ræret mig mnligt at se, men der er Rimelighed for, at deres Udspring forkolner sig som hos Branchiporliderne. Bagtil uigaar fra Hiesnegangliet ') lange Commissurer, der omgiver Spiseroret og nelentil forbincler sig med det 1ste Ganglion i Buggangliekjæden. Denne sidste (se Fig. $\$, 10,11$ bestaar af en stor Mrengde Ganglier svarende til det store Antal Fodder, og er irlethele be. tydelig stærkere udviklet em hos Branchipodiderne, ligesom den ogsaa viser et temmelig forskjelligt Udseende, noget nærmende sig til det los Plyyllocari deme. Fom hos disse, ligger Ganglieme (se Fig. 9) meget tat sammen, om de end er tydeligt skilte baarle red Laengde- og Trarrommissurer. Af de silste findes, som hos antre Plivllopoder, :2 for hvert Par Ganglier, og mellem tem er der en meget liden, trart oval Aaming, matens der mellem Lrengdecommissurerne er et storre, paa langs ovalt Mellemrum. Fra livert fianglion nlgaar til siden 2 streke Nerrestammer, hvoraf den forreste strax reler sig i 2 Grene; men angaemle disse Nerrestammers videre Forlob har jeg ikke kumet skaffe mig find Klarhecl Bagtil bliver Gangliekjaden (se Fig. 11, 11) gradris smalere og de enkelte Ganglier tattere sammentrængte, saart Commissurene mellem dem ranskeligt adslitles. Den ender $i$ en stmmp Spids paa det sted, hror de silste Par rudimentre Fordder findes. Fra deme bagerste [lel at' Buggangliekjærlen ulgar Nerverne for Halen; men heller ikke on disses For lob har jeg kunuet skatfe mig et klart Begreb.

Ovarierne (Tab. XIII, Fig. 1, 2, wv) reprazenteres af 2 temmelig roluminose og starkt lappede (Trganer, der strakker sig langs Sideme af Tamen igjennem Storsteparten af den fodbærende Del af Kroppen. De munler hrert med en kort Egleder red Pasis af 11 te Fodpar, og indeholder et indre Hulrum, der staar i direkte Fonlinulse med Eglederen. Lundersuges et Stykke af de num (vimier moler Mikroskojet, vil man finde, at ethrert sig uhiklende $\mathrm{Hg}$ er indesluttot i en Follikel, der rager trem tra Ovariets overflarle i Form af en afrundet, mere eller mincle fremspringende Blære. Ian finder par samme Atrkke Orarim Eg $\mathrm{E}$ alle Udviklingsstaclier, tra overordentlig smaa, kum ved found in the latter. From the anterior part there issues on each sirle, going a little mprarts, a short, thick nerve-stem, which is the optic nerve. After adrancing towards the lower surface of the eye, it is resolved into numerons divergent luranches (see fig: 7), each one of which unites with a corresponding vismal element. From the anterior encl of the cerebral ganglion, a tolerably strong nerve-stem passes forwards and sumpomds posteriorly, with its ganglionic: swollen end, the ucellns (see fig. D). It has not been possille for me to see where thr nerves for the antennæ originate, hnt it is probable that their origin is the same as in the Branchipodidae. From the rerebral ganglion. posteriorly, rum two long commissumes, which encircle the asophagus, and unite below with the first ganglion in the ventral ganglion chain. The latter (see figs. 9, 10, 11) consists of a consiclerable number of ganglia corresponding to the lange number of legs, and is in the whole, much more highly developed than in the Branchipodida, exhibiting too, a rather different appearance, somewhat approaching that of the Phyllo. carille. As in that group, the ganglia (see fig. 9) lie rery close together, although distinetly separated both ly longitudinal and transverse commissures. Of the latter there are, as in the other Phyllopoda. two to each pair of ganglia, and hetween them a very small, transversely oval opening, while between the longitudinal commissmes, there is a larger, longitulinally oval space. From each ganglion there issue laterally 2 strong nerve-stems, the anterior of which immerliately divides into '2 rami; but concerming the farther comse of these nerve-stems, I have been unable to ascertain anything clearly. Posteliorly, the ganglionic rhain (see figs. 10, 11) becomes gradually narrower, and the several ganglia more crowled, so that the commissures between them are dittienlt to distinguish. It enls in a blunt point at the place where the last pair of rulimentary legs are fomd. From this posterior part of the rentral ganglion chain issue the nerves for the tail, but in their case also, I have been mable to obtain any clear itlea as to the comse they take.

The ovaries (Pl. NIII, figs. 1, 2, ov) are repre. sented by 2 rather rolmminons and much lobed organs, extending along the sides of the intestine throughout the greater part of the buly. They each open br a short oviduct at the base of the 11th pair of legs, and contain an immer ravity, which is in direct communication with the nvidnct. On examining a portion of the dissected ovary muler the microscoue, it will be seen that each of the egg: modergoing development is enclosed in a follicle, which projects from the surface of the orary in the form of a rounded, more or less projecting vesicle. On the same piece of ovary are fomd eggs in all stages of revelopment, from exceedingly small rudi- 
meget stærk Forstorrelse synlige Anlæg til temmelig store, med et opakt Indlold fyldte Kaysler. I enhver Follikel findes alticl \& Coller combinerede. I de mindste Follikler (Fig. 13) er blot Kjememe synlige, medens i de storre Follikler (Fig. 14, 15), de enkelte C'eller skarpt afgræulser' sig fra hrerandre. Af de 4 Celler er det alene den yderste, der reprasenterer den egentlige Eg-celle; de 3 orrige er lim bestemte til demnes Emaring og absorberes derfor tilsidst ganske. Teme polare Celle skiller sig ogsaa lijendeligt tra de 3 orrige derved, at Kjernen er mindre skarpt contureret. Paa den fuldt ndriklerle Egcelle unddrager sig tilsidst Kijernen ganske for Observationen, og heller ikkp Kjemerne i de 3 Næringsceller kan sees pra Gruml at den opake, gulbrune Næringsblomme, som nu fylder det hele Eg (se Fig. 12). Er Eggene modne, trader de ind $\mathrm{i}$ Orariernes indre Hule og ndtommes derfra successivt gjemem Eglederen i 11te Fodprars Egkaprel, hror de ongives med en temmelig fast Skal (Fig. 16). Denne sidste viser sig red stærk Forstonrelse (Fig. 16 $\left.{ }^{1}\right)$ meget fint reticuleret, og dannes rimeligvis ved et af Kapselens V'agge afsondret Secret. I hrer Egkapsel finder man i Regelen kun et meget begramdset Antal Ag tra 1 enkelt (se Tab. N11, Fig. 17, ov) til 4, og de torbliver her km en ganske kort Tid, idet de successirt ndtommes af Kapselen og falder tilbunds, livor de indleires i Hudret, for til næste Sommer at urvilile sig til en ny Generation.

Testes liar samme Beliggenled som Ovarierne og ligner ogsaa ved torste Oiekast disse i Udseende. Ved narmere Undersugelse viser imidlertid Follillerne sig forholdsris mindre og af mere nregelmassig, noget affladet Form og ligesom slyngede ind $i$ himanden (se Tab. XIII, Fig. 17). I enhver Follikel er der (se Fig. 18) en indre Hule, der staar i For' bindelse med det centrale Hulnum, og fra Folliklernes Tægge ndvikler. Sxdelementerne sig i Form af meget smaa simple Celler (Fig. 19). Hvor 'Testes numunder, liar det ikke lykkets mig at faa constateret.

\section{Udvikling.}

.Teg har heller ikke af denne Phyllopode kimnet forfolge den hele Udvikling, men har dog leilighedsvis faaet fat paa en Del Jarvestadier, som jeg her noget noiere skal omtale.

Det tidligste observerede Stadium er afbildet Tab. XI., Fig. 4, og Detailler af samme, Tab. XIII, Fig. 21-27.

Legemet har en Længde (fraregnet Haletraa(lene) af kum omtrent $2 \mathrm{~mm}$., og er lialvt gjemnemsigtigt, af gulrod Farve. ments, only visible under a very high power of the microscope, to rather large capsules with oparum contents. In ear.l follicle, $t$ cells are always found combined. In the maller tollicles (fig. 13) only the nnclei are visible, while in the larger ones (figs. 14 , 15) the cells are sharply divided from on anotler. Only the outermost of the 4 cells represents the egg-cell proper; the other 3 only serve to nourish that one, and are therefore at last completely ab. sorbed. This polar cell is also easily distinguishabl. from the other three by the less distinctly ontlined nucleus. In the finlly dereloped egg-cell, the molens at last entirely withdraws from sight, nor can the 3 alimentary rells he seen on account of the vprayne. yellowish-brown foorlyolk which now fills the entire. orum (see fig. 12). W'hen the eggs are matnue, they enter the immer carities of the oraries, and are thence evacnated snreesively through the oviduct into the egg-capsule of the 11th pair of legs, where they are enveloped in a rather firm shell (fig. 16). This, when highly magnified (fig. 16), appears to he very firely reticnlated, and is probably formed ly a secretion from the walls of the capsule. In each capsule there is found, as a rule, only a rery limited number of ora, from a single one (see Pl. XIl, fig. 17 , ov) to 4 , and they remain there only a very short time, being discharged snccessively from the capsule, when they fall to the bottom, and are imbedded in the mud, to develope in the following summer into a new generation.

The testes ocrupy a similar position to the ovaries, amr also, at first sight resemble them in appearance. Upon closer examination, howerer, the follicles prove to he relatively smaller, and of a more irregular, somewhat flattened shaje, and are, as it were, twisterl abont one another (see Pl. AllI, fig. 17). In every follicle (see fig. 18) there is an immer cavity, in communication with the rentral cavity, and the sperm elements develope from the walls of the follicles in the form of very small simple rells (fig: 19). I have not sncceeded in ascertaining where the testes discharge themselves.

\section{Development.}

Of this Phyllopod too. I have been unable to follow the whole course of derelopment, but liave however occasionally succeeled in finding certain larval stages, which I will here describe more minutely.

The earliest stage observed is figured on PI. XI, fig. 4, and details of the same on Pl. XTI, figs. $21-27$.

The body has a length (not including the candal filaments) of only abont $2 \mathrm{~mm}$. and is semi-transparent and of a yellowish-red colonr. 
Rygskjoldet er rel ubriklet, men forholdsvis mindre hvalyet end los det roxne Drr, og har det lragre Indsnit bredere, næsten retrinklet. Den bag Rygskjoldet f'remragende Del af legemet er forholdsvis tykkere og mere sammentrangt end hos voxne Individer ogr rundtom saa tret besat med fine Pigge, at hen farr et laardent Uilseende. Segmenteringen er endnu lidet trdelig og egentlig km antydet ved de tæe paa hinanden folgende Tverrader af Pigge (se Tal. XIII, Fig. 27). Nidste Segment er dog meget tydeligt begrændset og ved en kjendelig Indknilming sondret fra de formliggende. Iet er ogsaa af' langt betydeligere Storrelse, og er aalsenbart sondret længe for disse. Af Form er det trapezoidiskt, gradris udvidet hagtil, og viser de 2 sidestillede dorsale Kinnder meget tydeligt. De ydre Hjorner af Segmentet er levebnerle med en Trærrad af stærke Pigge. Halepladen er nfuldstændigt udviklet og liun representeret ved en ubetydelig, $\mathrm{i}$ : $\mathrm{sy}$ metriske Spidser udgaaende Udridning af det dorsale Integument. Haletraalene er endnu ganske korte, neppe mere end $1 / 3$ saa lange som Legemet, og riser en nogret tendamet Form. De er rmult cm besatte med fine, tiltrykte Pigge, son dog ikke ordner sig i tydelige Trierrader, og har i Spidsen en særdeles lang og 2 liurte Pigge.

De sammensatte Gine (se Fig. 21, o) er forholdsris smaa og har endnu ikke Synselementerue tydeligt udvililede. Tmiddelbart foran dem sees meget tydeligt det enkle Oie (oc), ller næsten er af samme Storrelse som le sammensatte.

Forste Par Folere (Fig. 21. a') ligner i Udseende dem hos det roxne Dyr, men er forholdsvis storre, saa at de rager kjendeligt nd over Pande. randen. De symes eninu ikke at lrave Lugtepapiller udviklede, hrorimod en af de apicale Foleborster er af betydelig Længde.

Andet Par Folere (Fig. 21, a "), hvinat der hos det voxne Dyr kun er ubetydelige Rulimenter tillagre, er her mægtigt ndviklede, dannende et Par krattige Aarer, ver Hiælp af hrilke Larren bevæger sig raskt om i Tandet paa en eiendommelig stortris Maade. De er hrer sammensat af et stærlit, cylindriskt, ved Basis i flere Led delt skatt, der paa sin Encle bærer ¿ meget nlige udviklede Grene. Den pdre Gren er adskilligt længere end Skaftet, smalt eylindriskt, og delt i 5 tydelige Led, hrorat let 1 ste er vel saa langt som de 4 ovrige tilsammen. Hvert Lend hærer ven Enden en lang, tæot cilieret Srommeborste. Den intre Gren er meget liden, nepue mere end $1 / 3$ saa lang som skaftet, 2-leddet, $o g$ forsynet i spidsen med 3 ulige lange vilierede Borster.
The earapace is well developed, but comparatively less vanled than in the full-grown animal, and the posterior emargination is broader and almost rectangnlar. That part of the borly projerting beyond the earapace is comparatively shorter and thicker than in full-grown specimens, and so thickly covered all round with fine spines, as to present a hairy appearance. The segmentation is still very indistinct and really only indicated by the rlosely succeeding transverse l'ows of spines (see Pl. XII, fig. 27). The last segment, howerer, is very listinctly defined, and is separated from those in front of it ly a perceptible contraction; it is also far larger in size, and has pvidently been formed long before they have. Its shape is trapezoidal, gradually widening posteriorly, and it exhibits very distinetly the ? laterally-sitnated dorsal protulserances. The external angles of the segment are armed with a transverse row of strong spines. The canlal lamella is imperfectly developed, and is only represented by a rery slight expansion of the dorsal integument, projecting in two symmetrical points. The randal tilaments are still quite short, scarcely more than $1 / 3$ of the length of the body, and exhibit. a somewhat fusiform shape. They are set all round with fine, adpressed spines, which, however, are not arranged in distinct transverse rows; and at the extremity there is one particnlarly long spine and 2 short ones

The compond eres (see fig. 21,0) are comparatively small, and the risnal elements not yet distinetly developed. Immediately in front of them, the ocellns (oc) is seen very clearly, almost of the same size as the compound eyes.

The first pair of antennæ(Fig. 21, a ${ }^{1}$ ) in appearance resemble those of the full-grown animal, but are comparatively larger, so that they project percejtibly over the frontal margin. They do not as yet seem to have developed olfactory papilla, but on the other hand one of the apical sensury bristles is of considerable length.

The second pair of antennx (fig. 21, $\mathrm{a}^{2}$ ) of which there are left only slight rudiments in the fullgrown animal, are here powerfully developed, constituting a pair of strong oars, by the aid of which, the larva moves rapintly through the water in a peculiar, jerky manner. Each antemna is composed of a strong cylindrical scape, diviled at the base into several joints, and carrying at its extremity 2 very unernally dereloped rami. "The onter" ramus is considerably longer than the seape, narrow cylindrual and divided into 5 distinet joints, the first of which is rather longer than the other 4 together. Each joint bears at its extremity a long, densely-ciliated natatory bristle. The inner ramus is very small, scarcely more than $1 / 3$ of the length of the scape, is bi-articulated, and furnished at the 
Af Mundalene er (se Fig. "2l Orerlahen (L) og Kindbakkelne (MI) let at observere, og synes i alt vasentligt at ligne samme hos det voxne Dyr. If nogen Mandibnlarpalpe es ler intetsonhelst spol at se, skjonlt den ganslie sikknt har existeret par ot tilligere Stadinm. Tnderkiplon ug Kjæverne har jeg ikle knmmet noiere mulersoge.

Af Fouderne er de til Didtkroppen horende Par allerede talalig vel udviklede, med alle sine Hoveddele tylelige, hrorimorl te hagre Par blives i hoi fiad ludimentiere, forestillende tilsidst meget smaa, utroligt indskarne skiver uden enluver Borste lesatning (Fig. 26).

Forste Forlpar (Fig. 2-2) viser i Henseenle til Finditeme pudnu ingensomholst Forskjel tra de nermest folgende Par (Fig. 23), og den rilerste eller 5te Endit, der hos det voxne I'vr el ganske rndiment:er, er lor ligesaa vel udviklet som paa de tolgende Fonder. Derimol er Exoporiten kijendelig mindre og kun torsynet med \& Randbrister, melens den par odet Par (Fig. 23) lua ikke mind ene 14 sadanne. Ite Forlor (Fig. 24) er endnu limn lidet udviklet og riser intet 'Teg'n til nogen ELgkapsel. Exopoditen el paatvers oval og torsynet med en Rad af o fombldsvis korte Randhorster. Fpipoditen er meget liden, Enndeformig, og Enditerne afstumpede i Enden. Paa de folgende Par (Fig. .25) bliver, som oventor navnt, alle disse Dele endmere rudimentrere, og tilsidst (Fig. 26) er ler nepre mere end ubetydelige spor af dem tilbage.

At -indre Organer' kimner 'Tarmen meget tydeligt igjennem Integumentene (se Tab. XI, Fig. 4) og* el ialmindelighed fyldt merl rrangefarverle con tenta. Fontil ndsender den 2 linte Blindsakke (Tab. XIII, Fig. 21, 1), der hrer klorer sig i 2 Grene, livoraf igjen enhver er svagt trelappet i Enden. Dette er Begrndelsen til den hos det voxne Drr sar voluminose og complicerede Lever.

Et noget senere Stadium er fiemstillet 'Ial). XI, Fig. 5. Legemet har nu en Laengle af omtrent 4 mm. og er endnu halvt gjennemsigtigt, med et svagt gronagtigt Skjær og* guhod giennemskinnende Tarm. Rygskjoldet er nn forholdsris noget storre, men endnu temmelig tladt, og Kroplen har strakt sig noget mere i langde. Forovrigt stemmer dette Stadinm meget nær med det foreganende, og 2det Par Folere fingerer fremdeles som Svommeredskaber, skjondt de er noget redueerede i Storrelse, me dens Fodderne synes mere udrikterle. extremity with 3 riliaterl hristles of monepul length.

ot the oral parts (ser tig. 21), the latroun (I) and the mandibles ( $\mathrm{MT}$ no easy to observe, and seen in every pssential purticular to resemble those purts in the full-grown animal. There is no trare whaltever of a mandibulau nalp, though it must wertainls liave existed at an earlier stage. The postror lip and the maxille I have not been able to examine "losely.

The pairs of legs helunging to the mesosome are alcady tolerably well rovelopert, all their prinaipal parts being distinct, whereas the posterior pairs become extremely loulimentary, apjeajing at last like very small, indistinetly indented lamellas, entirely withont bristles (tig. 26).

As regards the endites, the first pair of legs (fig. 2:) presents as ret no ditterence whaterer trom the pairs immerliately following (fig. 23), and the outelmost or öth enlite, which in the full-grown animal is anite rudimentary, is here just as well developer as in the sureeding legs. On the other hand the exopulite is perceptibly smaller, and furnisher with only s marginal bristles, while that of the ond pain (fig. 23) las no less than 14 surlt. bristles. 'The 11th pail of legs (fig. 24) is as yet only slightly developed, and shows no sign of any egorepsule. The exopodite is transversely oral, and furnished with a row of : comparatively short mar. ginal hristles. The epipodite is nodiform ancl rer"y small, and the endites are truncated at the extremity. In the surceenling pairs (fig. 25), all these parts become, as stated above, more and more rudimentary, nntil at last (fig. 26 ) there is hardly more than a slight vestige of them lett.

Of the internal organs, the intestine shows werp distinctly through the integmments se Pl. XIJ, fig. 4), its contents generally being of an orange colons. It sends out in front. 2 short ræa (Pl. Xlll, fig. 21, 1), which earli livile into 2 hranches, each of which is in its tum slightly bi-lubel at the extremity. 'This is the rommeneement of the rery roluminons and complirated liver found in the full-grown animal.

Pl. XI, fig. ‘) represents a lather later stage. The body has now a length of about $4 \mathrm{~mm}$. and is still semi-transparent, with a faint greenish tinge, and the vellowish-red intestine showing through. The carapace is now rompuatively rather larger, thongh still somewhat flat, and the trunk has somewlat increased in length. In other resperts this stage agrees rery clusely with the preceding one, and the ond pair of antenna still officiate as swimming implenents, though they are somewhat redured in size, while the legs appear to be more developerl. 
I senere Staliex reduceres 2det Par Folere mere og mere og talier tilsidst sine crommejorster fuldstrendigt. hrorverl deres Betrluing som Berageorganer ar ophut. Bevagelsen overtages nu ndelukkende af de mere firldiomment uriklede Fodder. Haleplarlen begrniley saa smat at forlange sig og far Here Randtorne, men er endum hos temmelig store Tnger meget lilen (se Tab. XIII, Fig. -os).

Levevis, - Nærrarende Phyllopode synes ikke, som Tilfidet or med de Heste orrige Former, at viere udeluktiende indskanket til mindre Tandansamlinger, som ud paa sommeren torres ganske eller delvis url. Teg har trentimor hiltil kmn fundet den i temmelig store og drhe rande, og har seet den yaa 1)ybler af mindst $3-1$ Favne. Sm Regel holler den sig lige ved Bumben og svommer lang deme, altid med Riggen opad. Hen ikke saa sjelden tager den sig ogsaa Ldfugter hoiere op i Tandet og vender herunder suart livg, snart Bug opad, eller dreier sig rundt pait torkjellig Vis. Frommingen tilrejebringes hos let voxne lyri mlelukkende red Hjalp af Forlderne og foregar med en ganske, jern og ikke meget luutig Fart.

De grovt tandede Kindbaklier og de stiprke liloformige knditer pas de forleste l'ar Fodder tyder paa, at Itret lovedsageligt lever at Rov, rimeligris for en stor Del at andre Fntmostraceer. Jeg hav ogsaa iklip sjeldent mellem Forlderne paa dem fundet Dajhmier og forskjellige Copejoler iryolops. Heterornpe). Fiter Sigende slat den i visse Tiltalle ogsaa furture Fiskerogn og derved blive sliallelig for Irisliebestanden i de Tande, hrori den toreliommer.

De allerfleste Individer, man traffer, er af Hnnkjom, "g det er forst efter et meget noie Eftersm af talrige Exemplarer, at det er lykkets mig at finde frem nogle fin Hamer. Ffter al Sandswnliglied er Hammernes Forekomst km indskranket til en ganske kort Periode, rimeligvis til Slutten af Sommeren.

Forekomst. - Sely har jeg her i Landet kim truffet den par Filefjelds Hriclejatean, omking $N^{\top} \mathrm{y}$. stuen, dels i selve Nrsturandet eller i Tdriduingen at den trit samme mod Vest ndratende Elv, dels i et Fjaldrand, Tesleskartjernet lialdet, pai selre Nrstutjeldets livor og i en Hoide af rirea toco Forl nvel Havet. I det silstureverte Tand, der ex tem. melig dytut, findtes den i chntningen af' Angust 1887 i stru Mangre, ug knule tral stranden af giemnem det krystalklare Tand sees overalt par Bunden. Kinn mudtagelsesris tandtes den saa ner Stranden og pai saa mmurt. Vand, at den kunde tages med en almindelig Haand-Haar, "g min Fangst af den indskiankide ig derfor ogsail, furste rang, jeg besogte dette Viud, fim til nogle taa Fxemplarer.
In later stages the 2nil pair of antemure lopcome more and more reduced in size, and at last entirely lose their matatury bristles, whereby their impor tance as organs of nution ceases. The prodnction of motion is now mulertalien exclusively by the more tully dereloperl legs. The eandal lamina eommences slightly to lengthen, and aepuires several marginal spines, but is still, even in rather large romig ones, very small (see Pl. XIII, fig. 28).

Habits. - The present Phylloporl does not seem, as is the rase with most of the other froms, to be exdusively confined to small pieces of water, which either quite or partially dry up towards the end of the summer. On the comtrary, I have hitherto only found it in rather large and reen lakes, and have seen it at rlepths of at least 3 or 4 fathoms. As a rule, it keeps to the hottom, where it swins along, alwars with its back mpuermost; but it not inferpuently makes exumsions higher. "I' in the mater, and during thrse, turns sometimes its bark, sometimes its ventral surface mpermost, or twists abont in rarions ways. The action of swimming in the finll-gown animal is performed exchsively In the ail of the legs, and at a perfertly even, and not very rapid rate.

The eorarely dentated mandibles, and the strong "law-lilie endites of the foremost pairs of legs incli. "ate that this animal lives principally by preying on others, mobably to a large extent on other Entomostrara. I have also not infremmently fomd between its legs laphnia and varions copepods (Cyctops. Heterocopes. Arcording to report, it has also, in certain cases, been known to consume fishspawn, and is thus letrimental to the stack of fish in the lakes where it ocrurs.

"The greater number of specimens net with are of the female sex, and it is only atter a very careful examination of mmenous specimens that I have sueceented in fincling a few males. In all probability, the occmience of the males is limited to quite a short period, molobly mutil the end of the summer.

Occurrence, - In this comotry (Nopray) I have personally only met with this form on the high plateau of the Filetjeld, abont Nystren, partly in Nistme Lake itselt' amol the expansions of the liver flowing ont of it towards the west, and partly in a monntain tarn called Tesleskartjern, on the ridge of Nystme Momntain, and at a height of about 4000 feet above the sea. In the last-mamed lake which is rather deep, this species was fomm at the end of August, 15,7, in gueat numlsers, and romld he seen trom the shore, throngh the clear water, all over the bottom. (1) $\mathrm{y}$ in exceptional wases was it fomd so near the shore and in such shallow water, that it could be taken with an ordinary lund-net, so that my take of it, the first time I risited this lake, 
Forst elterat jeg havle tursyet mig menl en meget lang, 4-5 Alens stang, til hvis Ende Haaven fast. bandtes, kunde jeg tange rlen i storre Antal; men mange lixemplarer gik endnu saa drit, at det var mmuligt at naa i lem.

Foruden paa Filefjeld er ilen at" nu atidode Gartner Toe taget i Lom, og at Landskabsmaler Skarj red Kongsvold paa Dovrefjeld. I Finmarken er den derimod, saavidt mig belijpnlt, alıhig bleren pautruflet, ligresaalidt som i havlanlet syd paa. Deme Phyllopode er saaledes hos os ntvivlsomt en irgte "relict Form, der kun i vore Huifjelde endnn har fundet te notvendige Betingelser for sin Existence.

Udbredning. - Arten liler forst fundet i Gronland, livor den srnes at rere meget almindelig. Senere or den ogsaa observeret i ret arktiske Amerika, paa Sipitsbergen, paa Novaja Semlja og i Sihinien. ben er saaledes en agte arktish Form, og i sin Udbredning rirempolar. was limited to a vely lew aremens. It wat mly when I had provided myelf with a rery long rod - s or 10 feet long - to the end of whicls the net was attached, that 1 was alile to capture them in larger numbers; and many of them were still in such deep water. that it was impossible to ret at them

Besides heing fonml on the Filefjeld, it was found by the late Horist. Noe, in the Isom, and by landscape-painter Skari at Kongsvold on the Dove Wountains. On the other hanl, it has never, to my knowlerlge, been met with in Fimmark, nor yet in the sonth lowlands. This Plyyllopod is thus in this country (Norway) a true velict form, which las found only on onr monntains the conditions necessary for its existence.

Distribution. - The species was first found in Greenland, where it seems to be very common. It has since been observed in arctic America, on Spitzbergen, Novaia \%emlia, and in viberia. It is thus a true arctic form, and cirmmpolar in its distribution.

\section{Sectio III. Conchostraca.}

\author{
Syn: Phyllopoda conchiformia.
}

Characteristik. - Legemet omgivet af en stor, treklajpet Skal af chitinos Structur og frestet til samme ved et smalt dorsalt Ligament. Valrlerne bevagelige ved $H_{j}$ jpl at en strerk Lukkemuskel og forbmulne dorsalt med hinanden ulen nogran egentlig Laas. Hovedet bevægeligt og vel sondret fra kropjen, gaaende nd i et mere eller mindre fremragende sammentrylit Rostrum. Kroppen pusformigt segmenteret $n g$ endende med en lont, mere eller mindre ombsiet Haledel, sadranligris forsmet i Enden med ¿ strerke beragelige Klor og bærende dorsalt 2 jevnsides stillede Borster. De sammensattp Oine nær sammen, undertiden sammensmeltede, $n g$ beliggende i det indre af Hoverlet. Thet enkle Gie vel udviklet. Begge Par Folere tilstede, 1ste Par torholdsvis snaa, enkle; 2det l'ar omlanmede til krattige, tvegrenede Svonmeorganer. Mundlelene narmest lignende dem hos Grmpen Anostraca. Forderue af uniform Bygning, pladeformige, Higede, med tydeligt ndviklet Coxallap og med Exnporliten delt i en dorsal og en ventral luap; det 1ste eller de

\section{Section III. Conchostraca.}

\author{
Syn: Phyllopoda conchiformia.
}

Characters. - Borly sumponded by a large hivalved shell of clitinum structure, to whin it is attached by a narrow dorsal ligament. Talves movable by the ail of a strong adductor muscle. and comnected donsally with one another without having a true hinge. Head movable and welldefined from the trunk, terminating in a more or less prominent, compressed rostrum. Trunli aniformly segmented, ending in a short, more or less deflexed caudal jart, generally provided at the extremity with two strong, movalble rlaws, and bearing dorsally 2 juxtaposed hristles. Compound eyes close together, sometimes merged into one another, and situated in the interior of the hear. Ocellus well developed. Both pairs of antenua present, 1st pair comparatively small, simple; 2nd pair transformed into powertil, hi-ranons natatory organs. Oral parts most nealy resembling those in the Anostraca group' Legs of muitom structure, lamellar, lobate, with distinctly developen coxal Jobe, and with the exopodite liviled into a dorsal ant a ventral lobe; 
2 forleste Par los Hamen omdannede til Giriberedskaber. Egrene neget smaa, bares sammenhoberle ind moler den dorsale Thel af Skallen. Td. vililingen, naar moltages Sliegten Cyctestheria. en compliceret Metamorphose, berruclende med et Nanplins-stadium.

Bemærkninger. - Demue (irulue at Pluyllopoder adskiller sig fra de 2 toregataende ved en Prokke af vel uduragede charaterel' og damner paa en Maade Grergangen til Cladocmmne. Sum den mest ioine faldeude C'haracter ma fremlixves den store treklappede skal, hvori Leyemet fuldstiendigt kan inddrages, og som ofte riser en skutfende Lighed med Stiallen los visse bivalve Mollusker. Ogsaa 2det l'ar Foleres Brgning los det voxne Tyr el rasentlig torsijellig, idet de her, som hos Larverne af line, damner et l'ar linatige, tregrenede Aares', hrormed Drret ror sig frem igjemen Tamlet. Gruppen indeholder for Tiden 2 distincte Familier, nemlig Limmalide og Limmetide, som begge er representerele i Norges Famur. the lst pair or the first 2 pairs in the male transformed into prehensile implements. Ora rery small, carried crowded together beneath the rorsal part of the shell. Jevelopment, except in the case of the genus Cyclestheria, a complicated metamorphosis, commencing with a mauplius stalium.

Remarks. - This group of Phyllopoda is distiuguished from the 2 preceding grous ly a number of well-marked "haracters, and in a manner forms the transition to the Cladocera. As its most conspicuous (haracter must be noted the large bi-ralrer shell, into whirb the body an lue completely with drawn, and which often shows a striking resembiance to the shell in certain hi-valve Mollusca. The structure of the sfecond pair of antemne in the full-grown animal is also essentially tifterent, tomming liere, as in the larve of other Phyllopods, a frair of powerfnl, bi-ramous oars, with which the animal propels itself' through the water. 'This group' contains at present 2 distinct families, viz, Limm $t^{-}$ riide and Limmetide, both of whirh are represented in the famna of Nolway.

\section{Fam. 1. Limnadiidæ.}

Characteristik. - Skallen ialmindelighed sammentryt og forsynet los roxne Individer med et vexlende Antal af' Trextstriljer. Hovedet af middels Ftorrelse og kun liret forskjelligt hos de $2 \mathrm{~K}$ jon. Kripipen forlanget og meget beragelig, Haledelen rel udviklet, omboiet, dannende bagtil 2 jernsides stillede tandede P'lader, og endende med s bevageligr Kilor. Forste Par Folere mere eller mindre forlæengede, og siedvanligvis lappede i den ene Kant; 2let Par med Grenene slanke og hetydelig læengere end skaftet. Kindbakkennes Tyggetlade uden tydelige Tiender. Folderne talrige, fra 16 til 28 Par, med forholdsvis kurte Enditer; den dorsale Lap af Exopoditen forlænget hos Hnunen paa 2 eller 3 af de midterste Par til traalformige Tedhang, stottende Egmassen.

Bemærkninger. - Ienne Familie er lovedsageligt characteriseret red Skallens Form og Structur, det betydelige Antal Fodier og Haledelens tydelige Udrikling. Den indeholder for 'Tiden 4 Slagter, nemlig Limnadia Brogniart, Eulimatia Packari, Estheria Riijusel og Cyctestheria G. O. Sars. Hus os er blot den forste af "lisse ilagter reprasenteret.

\section{Fam. 1. Limnadiidæ.}

Characters. - Shell generally compressed and furnisher in the tull-grown animal with a rarying number of lines of growth. Hearl of medium size. and only shighty different in the 2 sexes. Trunk elongated and very movable; caudal part well developed, curved downwarls, forming posteriorly 2 juxtaposed dentated lamelle, and terminating in 2 movahle claws. First pair of antenna more or less elungated, and generally lobed in one margin; second pair witl slender rami, consirleraloly longer than the suape. Masticatory part of the manclibles without distinct teeth. Legs numerous - from 16 to 2 pairs - with comparatively short enclites; dorsal lobe of exopodite in the female plongated, in 2 or 3 of the middle pairs, into filiform apremdages, sujplorting the egromass.

Remarks. - This family is principally characterised by the form and structure of the shell, the large number of legs, and the conspicuous ilevelopment of the caudal part. It contains at present 4 genera, viz. Limnadia, Brogniart, Eulimadia. Packard, Estheria, Riippel, and Cyclestheria, (i.O. Sars. Only the first of these is represented in Norway. 
Gen. Limnadia, Brogniart, $1 \times 20$.

Slægtscharacteristik. - Mliallen stærlit sammen-

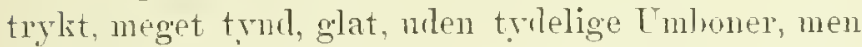
hos det rome Tyrr med talrige Vaxtstriber. Horedet forluldsvis lidet og forsinet med et stilket dorsalt Fastheftningsorgan, Panderdelon konisk fremspringende $o g$ sondret fra Rostrum ved en vinkelformig Inthugtning. Foklernes Antal omking 24 Par, den dorsale lape af Exopwiten liun lidet fremragende; Epiporliten forlondswis liden. Halepladerne ndtrukne nerlentil i et tilspidset, iklse kluformigt Horne og fint tandede bagtil. De sammensatte bine trdeligt adskilte, skjondt tipt sammenstillede; let enkle Vie triangulært. Forste P'a Folere torholdsris korte, men tydeligt lapperle $\mathrm{i}$ sin yrle [lel; - det l'ar med den indre (xren langere end den ydre, liegge delte i talrige skiveformige Led, besatte i den intre Kant med lange srommeborster, $i$ den ville merl korte Pigge. Aggrene meget smaa, omgivne af en turbinformet Slial. Forplantningen ndelukliende parthenogenetisk. Cilvililingen en complet Metamorphuse.

Bemærkninger. - Slregten Limmadia l,ler forst opstillet at Brogniart allererle i 1820, medens Slægten Estheriu daterer sig fra en langt senere Tid, hrorfor ogsaa Familien bor lenewnes efter den forste og ikke, som det ofte er skeet, efter den silste slregt. Fra Slægten Estheria el nærverende slangt let kjendelig ved den struliere sammentrylite ing tyndere Skal, paa hrilken ingen tydeligw Umboner findes, red Horedets meget forskjellige Form, tildels ogsaa red 1ste Pau Foleres, Eoddernes og Halepladernes structur. Meget nærmere staar den Slægten Eulimadia Packard, og den eneste mere rasentlige Forslijel symes at vitre, at Arterne af denne sidste Slagt er, ligesom de af S1. Listheria, lisexuelle, medens Hanner af sil. Limmalia endnu iklie, trods the omlyggeligste Efterforskninger, er forefumlne og rimeligris heller ikke existerer. Man kjender hidtil med Sikkphlied km 2 Arter af denne Sliegt, en enropeisk og en amerikansk, $L$. americuna Morse. De ovrige til demne Slægt hemregnede Arter synes alle at lenhore til den nærstaaende Slægt, Eulimudia.

\section{Limnadia lenticularis (Lin.)}

\section{(Pl. XIV-XVII).}

Monoculus lenticularis, Linné, Fauna Srecica, Edit. 2da. J. 499.

Daphnia gigas, Herman, Méw. apterol. p. 13I, PI. V, fig. 4, 5, Pl. IX, fig. a.

Limnadia Hermanni, Brogniart, Mém. du Mus. d'hist. nat., Tome I'I, p. 84, I'l. 13.

Limnadia yigas, Grube, Archiv f. Naturgeschichte, 19 Jahrg., B.l. 1, p. 151.

Artscharacteristik. - Sliallen, seet tra Siden, bredt oval, med den storste Hoide foran Midten,
Gen. Limnadia, Brogniart, 1\%20.

Generic Characters. - Shell greatly comperserl, very thin, smosth, rithont distinct umbrues, lnat with numerms lines of growth in the full-grown animal. Hear comparatively small and fumisher with a stalked dorsal affixing organ; fromtal jart conically projecting, and ilefined from the rostrnm by an angnlar sinus. Number of feet, about 24 pairs; dorsal lohe of the exopolite only slightly projecting; epripodite comparatively small. Candal lamellæ drawn unt be] ow to a sharp, not clawlike angle, and finely dentated posteriorly. ('ompound eyes quito distinnt from wne another, thongh placed close tugether: ocellus triangular. First pair of antenure comparatively slort, but distinctly lohed in their distal portion; 2nd pair with the inner ramus longer than the onter, and both divider into nnmerous laminar joints, clothed on the inner edge with long natatury hristles, on the outer with short slines. Ova very small, surrounded by a turbinate shell. Propagation exchsively parthenogenetie. Derelopment a complete metammphosis.

Remarks. - The genu.s Limmolliu was first established by lorogniart as early as 1이, while the gemus Fisheriu dates from a much later time. The family ought therefure to be named after the first genns, and not, as is so uften done, after the last. The present genus is easily distinguishable from Fstherit by the greater compressiom and thinness of its shell, on which no distinet nmlunes are to be found; by the very different form of the head; and to som extent ly the structure of the 1st pair of antennæ, the legs, and the caudal lamellix. The genns Eulimatia, Packard, is far more rlosely allied, and the only essential difference seems to be that the species of this last gemus, like those of the genus Estheria, atre bi-sexual, while males of the genns Limualia, in spite of the most carefinl investi gations, liave not yet been found, and probably do not exist. Only two species of this gemm are as yet known, one Enropean and one Amerion, $L$. americana, Morse. The other species reterred to this genus would seem all to belong to the nearlyallied genus, Entimedia.

\section{Limnadia Ienticularis (Lin.)}

\section{(Pl. XIY-XYII}

Monoculus lenticularis, Linnseus, Fauna sivecica, Edit, 'zda, 1. 499.

Daphnia gigas, Herman, Mém. apterol. p. 134, Pl. V, figs. 1, 5 Pl. IX, fig. :

Cimmadia Hermanni, Brogniart, Mém. du Mus. dhist, nat. Tome VI, p. 84, Pl. 13.

Limnadia gigas, Grube, Archiv f. Naturgeschichte, 19le Jahrg. Bd. I, P. 154 .

Specific Characters. - Shell, seen from the side, broanly wral, with the greatest height in front 
Rygkanten hus fuldroxne Individer stærkt buet i sin forreste Ilel, Bungkanten jernt convex, Forenden meget kort, afstumpet, Bagenden noget nddraget og smalt tillundet, med en tydelig Vinkel orentil seet orenfra smalt tenfurmig, bredest form Midten. Trxtstriberne ilki meget skarpt markerede, og rexlende efter Alderen indtil 15 pa hrerside. Hovedet nasten at triangulær Form, med Paudedelen smalt konisk og skilt tra det triangulære Rostrum red et drbt vinklet Indsnit. Fodulernes Antal hos fuld. roxne Individer 24 Par, :-11te Par med Exopoditens dorsale lap tradformigt forlanget. Halepladerne herer med 10 -16 sma Tagger ovenfor det torntormigt nultrukne nedre Hiome; Haleklone fint tandede langs den concave Kant og besatte med tine Borster i den basale Del. Farven mere eller mintre trdelig olivengron, Fublderne ialmindelighed lyst gulrode. Laengden af skallen inctil $17 \mathrm{~mm}$.

Bemærkninger. - Alierede Herman har ytret den Formodning, at let af ham som Daphnia gigas beskrevne Drr maask kumle ræe identisk med Limnéx Monoculus lenticularis, og ugsaa Grube ${ }^{\mathrm{l}}$ ) synes at rære at samme Mening. De senere af Prot. Lilljeborg.2) anforte Data synes endmere at luekræfte Rigtigheden at denne Ansknelse, og det foreliommer mig derfor nu at rare fuldt berettiget at optage igjen den Limeiske Artabetegnelse, lenticularis. saameget mere som den er noksaa betegnende. Det Navm, hromuder nerrerende Form af de fleste Fortattere, ogsaa af Prot. Lilljeborg, er opfort. er Limmadia gigus.

\section{Beskrivelse.}

Hos de storste at mig observerede Exemplarer har skallen en Liangle at" $12 \mathrm{~mm}$. og en Hoide af 9 mm. Prof. Lilljeljorg har fumlet den at kumne naa en Længde at inctil $17 \mathrm{~mm}$. og en Hoide at nap $13 \mathrm{~mm}$. Men en saalan Storrelke syos dog at matte ansees som exceptimel.

Skallen, der fuldstrendigt omslutter Dyret, saa at kum den forreste Del af Hovedet med Aareme og Halen kan strokkes udenfor samme, er stærkt sammentrykt tra Rileme og temmelig tyond ag giennemsigtig, hrortor legemet sees meget trdeligt igjennem samme (se Tab. XI, Fig. 1). Den bestaar at "- smetriske Halvdele eller Valvler, der langs Irorsalsiden storler sammen under en spids Tinkel og her er fast forbundue med linanden, uden nogen virkelig Laas. Da imidlertid skallen er meget elastisk, er Valvleme til en vis Grarl bevægelige

1) Teber die Gattungen Estheria und Limnadia, P. 68

2) Ufversigt af $\mathrm{K}$ gl. Vet. Ikad. Forhandl. 1871, p. 824. of the midlle; dorsal margin, in full-grown specimens, much arched in the foremost part; rentral margin evenly curved, anterior extremity very short and blunt, posterior end rather elongated and narrowly rounded, with a well-narkerl angle above seen trom above narrowly fusiform, with the greatest breadth in front of the middle. Lines of growth not very rlearly marked, varying according to age np to 15 on each side Head almost triangular, with the frontal part narrowly conical and separated from the triangnlar rostrum by a deep angnlar notels. The number of legs in full-grown specimens 21 pairs, the !th to the 11 th pairs having the dorsal lobe of the exoporlites elongaterl in the form of filaments. Candal lamellæ each with from 10 to 16 small denticles above the spine-like, elongated lower comer; caudal claws finely dentated along their concave edge, and the basal part clotherl with fine bristles. Colour more or less distinctly oliregreen, legs generally light pellowish retl. Length of shell up to $17 \mathrm{~mm}$.

Remarks. - Herman has alrendy sumised that the animal described by him as Daphinia gigas may perhaps be identical with Linneus's Monoculus lenticularis, and (irube ') seems to be of the same opinim. The data subsequently finmished by Prof. Lilljeborg ${ }^{y}$ ) seem still further to ronfirm the correctness of this view, and I therefore feel fully justified in adopting again the Limean specific designation, lenticularis, the more so as it is fairly characteristic. The name by which the present form is specified by most anthors, Prof. Lilljeborg included, is Limnadiu gigas.

\section{Description.}

In the largest specimens examined by me, the shell has a length of $12 \mathrm{~mm}$. and a heiglit of $9 \mathrm{~mm}$. Prof. Lilljeburg has found it attaining a length of 17 mm., and a height of nearly $13 \mathrm{~mm}$.; lut such a size must probably be eonsiclered exreptional.

The shell, whirh completely envelopes the animal, so that only the anterior part of the liead, with the oars and the tail can be extended from it, is greatly compressed, and rather thin and transparent, so that the body is distinctly seen throngh it (see Pl. XIV, fig. 1). It consists of 2 summetrical halves or valves which meet at an acute angle along the dorsal sirle, and are there tirmly uniterl to on another, withont any true hinge. As, however, the shell is very elastic, the valves are movable to a certain extent, and can be opened a little,

1) Ueber die Gattungen Estheria und Limmadia, p. 68. 2) Ofversigt af Kgl. Vet. Akad. Forhandl. 1851, p. 824. 
rg kan aabnes noget eller lukkes etter Dyrets Behag. I sidstnærnte Tilfolile slntter deres frie Kanter tat mod hinanden, saa at lyyret er hermetisk indesluttet i skallens Cavitet. Skallen er fastet til Legemet oventil ved et temmelig smalt Ligament og noget nerlenfor dette til hver side ved den starke Lnkkemuskel, hris Insertion til Indersiden af hrer Talvel viser sig som et rel begraendset rundagtig Felt i demes forreste Del. Umiddelbart hag dette Felt sees Skalkjertelen strokkende rig paaskraat bagorel hrer. Valvel seet fra siden (Fig. 1) viser Skallen hos fuldt urroxede Exemplarer en noget mregelmassig, bredt oral Form, med den storste Hoide, der salvanligvis overstiger $2 / 4$ af Lapnglen, beliggende foran Midten. Iorsalkanten er hos aldre Exemplarer meget starlst lunet i sin forreste Del og legrandset fortil ved an temmelig utydug stmmpinklet Afsats, bagtil verl et noget strerkere fremtrædende Hjorne. Nerlenfor disse Hjorner begrnder Talvlemes frie Kanter, og disse danner i hele sin Længde en natbudt og fuldlimmmen jevn Bue. Forenden af Skallen er meget kort og afstumpet, medens Bagenlen er noget uddraget og smalt tilrundet. Paa Silerue af Skallen sees et Antal meget fine concentriske Linier, de sarkaldte Taxtstriber: Ileres Antal er varierende efter Alleren. Hos de storste af mig olserverede Tndivider har jeg talt 11 sarlame Striluer paa hrer Talvel; men Prof. Lilljeborg har paa namindelig store Exemplarer tundet indtil 15 Par Vaxtstriber. Alle disse Nitriher convergerer mod det forreste Hione at Sikallen, og ligger folgelig lier tret sammen, hvorimod de bagtil encler i forskjellig. Hoide lang Dorsalkanten af Skallen. De rilerste Linier, som ialmindoligher er tattere. lober nogenhnde parallelt med Talvlenes frie Kantex; ved den inderste Linie begrændses oventil et ovalt Felt, hvor skallen har sin storste Trerle, og indentor hrilket Insertionsareaen for Skallens Lukkemuskel og sikalkjertelen har sin l'larls. Seet orentia (Fig. 2) eller nedenfra (Fig. 3) viser vikallen en meget smal, noget tendannet Form, med den storste Brede, der er betydelig mindre end $1 / 3$ at I angden, foran Midten.

Hrad skallens finere Bygning angaar, saa riser den en fuldkommen glat og glindsende Overtlade, mon Spror af nogen rdre Sknlptur. Tlen er imirlertirl, ligesom Rygsioldet hos Lepritums, sammensat af 2 ræsentlig forskjellige Dele, en vire, tilsyne. ladende af Here Lag bestaaende chitinos skikt, og en indre membranos Beklæuning; der damer en Fortsattelse at Legremets Integument. liegge clisse Skikter er forbundne med hinanden vel talrige 'Tværbjælker', der delvis sees udvendigt som uregelmæssige opake smaapletter, og mellem lrvilke den or shut according to the pleasure of the animal. In the latter ase, their free erlges fit "lusely together, so that the animal is hermetically enelosel in the shell's ravity. 'The shell is attacherl to the hody above by a rather narrow ligament, aml a little below this, to each side, by the strong arldnetor musele, whose insertion on the interion smrface of each valve apjeal's as a well-definesl cimnlar area in the toremost part of the value. Immediately behimd this area, the shell-gland is soen extending oblinnely backwarls wer each valve. seen from the side (fig. 1), the shell, in fully-grown specimens, exhibits a rather irregular, broally oril form, with its greatest height, which generally exceeds $3 / 4$ of its length, in front of the midlle. "The dorsal margin in oller animals is rerr mucls curved in its froremost part, and bonulerl in front lis a somewhat indistinut, whtnse angled projection, lielind, by a rather more sharply jojerting angle. Thelow these angles begin the free edges of the valves, and these form thronghont their length an mintermpted and perfectly even "mre. The anterior end of the shell is very short and bhunt, while the other end is rather drawn out, and narrowly roundorl. On the sides of the shell, a number of very tine concentric lines are visil)le, the sorcallocl lines of growth. Their number varies aroorting to age. In the largest specimens rxamined by me, I liave comnter 11 such lines on each ralve; lut Prof. Lilljeborg has found as many as lo pairs of lines of growth on musually large specimens. All these lines converge towards the anterior colner of the shell, and consequenty lie close together there; while at the back they end at clifferent heights along the rorsal edge of the shell. The ontermost lines, which are generally closer, run to a certain extent parallel with the frep erlges of the valves. The intemost line lounds, above, an oval fiell where the greatest brealth of the shell occurs, and within whith the area of insertion of the shell's addnctor muscle, and the shell-gland are situaterl. Seen from abuve (fig: 2) on trom belour (fig. 3), the shell exhibits a very nirrow, somewlat funiform shape, with the greatest breasth, which is considerably less than $1 / 3$ of the length, in fiont of the middle.

As regards its nore delirate structure, the shell presents a perfectly smooth and shining surface, withont a trace of any external somptuing. It is, however, like the calajace in Tepiourus, eomposed of two essentially diflirent pats, an exterin "hitinous coating apliarently consisting of several layers, and an internal momlnanous lining, forming a coutimation of the integment of the body. Buth these strata are comnerted with one another by numerous crosslors, which are partially visible externally as small, incegular, oparue spots, and between which 
el compliceret sistem af Hulpum, Jroni Blodet circulerer. Mellen disse Skikter af skallen er ogsaa sikalkjertelen heliggende. llenne sidste viser sig red napruere. Unulersogelse (se 'Tah. XV, Fig. 1t) at lestaa af en there (iange slyngeformigt bugtet hanal, der tortil delvis ongiver Insertionsareaen for skallens tulikennskel, men hvis Hovedrlel ligger nmiddelloat bag samme. Kanalens Tdgangspmlit sones at ligge lige orer den sidstnarnte Area og ontrent paa samme Sted ogsaa dens Ende; men nogen skar Begrandsning mellem begge har jeg dug ikke kunnet parvise, og det ex muligt, at der her er en direkte Kommunkation, saa at Kanalen i Virkeliglyeden damner et i sig sely tilbagegaaente Ror. Bag Muskelaueaen damer Kanalen 3 ind i liverandre liggende tungefurmige Slynger, ıler, om man forfolger Linalen tia dens tilsyneladende Udgangsumlit, folger jaa hinanden i en saadan (rolen, at den mid terste slynge er den forst dimnede, den vierste len aden, og den inderste ren : die. Den mirterste og yderste silynge ex forbundet ved en smalt ullolyenle. tmoneformig omboining, ler strakkpl sig dorsalt fororer, og ender lige over Kanalens lidgangspmlit. Den vderste og inderste strnge gaar vrer i hinan den verl en lignende, nen hredere umboining, der ligger mere ventralt, lige nedenunder Muskelareaen, og her krrilser ten torreste Trel af Kanalen. Oreralt visel hanalens lionturer sig uregelmassigt takliede, $o g$ i llens Trgge sees spreite r'ellekjerner, givenule den et glandulost Uidseende.

Thet i Fiallen indeshttede Dyr (se Tab. IV, Fig. 1 inclager en forhullsvis liden llel af skaleaviteten, hrori llet er frit suspenderet, kun fastet helt fortil red det ovenomtalte inrsale Ligament og rel Skallens Lukkemukel. Saavel den foran som bagenfor ligoende bel af Legemet er derfor frit hevagelig, og there Mnskler sees ogsaa at jassere fra let dorsale ligament saarel fortil som hagtil. Legemet Iader sig naturligt dele i 2 Hovedafsnit, der med hinandin damer en storre eller mindre Tinkel, ug hris Begrendsning antryles red det dorsale Ligament og Lukkemskelen. Det foran disse bele liggende Afsnit er meget mindre end det bagenfor liggende og kan igjen doles i 2 underordnede Afsnit, legrandsale fra hinanden oventil verl en dyb Indbugtning. Den forreste Del er rlet egentlige Hored, den bagerste det saakaldte Nakliesegment. Thet bagenfor det dorsale tiganent og Lukkemuskelen liggende, sardeles levagelige Afsnit larler sig ligeledes dele i 2. den egentlige Krop (truncus) og Haledelen, hroraf den forste er af meget betylelig storrelse, den anden ganske kort.

Af' ydre T'edhang barer Hovedet de 2 Par Folere og fortsatter sig bagtil par Undersiden i Overlaben. there is a complicated system of cavities in which the blood circulates. Between these strata of the shell, the shell-gland is also situated. This last proves, on a dosp examination (see Pl. XV, fig. 14) to consist of a twisted chamnel curled up in several windings, which in front partially surnomd the area of insertion of the shell's arductor muscle, but of which the greater number lie immerliately belind it. The point of issue of the channel appears to lie just orel the above-mentioned area, and its end also at about the same place; but I have not been able to malie ont any sharp bomdary betreen the tro. and it is possible that there is here a direct communication, so that the channel forms in realitx a tube running bark into itself. Pehind the musenlar area, the rhamel forms 3 linguiform coils lying withim one anotler, which, if the comrse of the chammel be traced from its apjarent origin, so follow one another, that the millle coil is the first formed, the outermust one, the second, and the imermost, the third. The midulle and ontermost roils are comnecterl by a narrowly jojecting, lingular fold, which extemls formards dorsally, anrl ents just abno the starting print of the cliannel. The ontermost and immermost roils run into one another with a similar, lut lroarler foll, which is more rentral in josition, just below the muscular area, and here arosses the front part of the chamel. The outline of the chamel is throughont irregulary jaggerl, and scattered cell-nuclei are visible in its walls, giving it a glandular appearance.

The enclosed animal (see Pl. XV. fig. 1) ocenpies a comparatively small purtion of the carity of the shell, within which it is freely suspended, being attached mly at the vers front hy the before-mentioned dorsal ligament and by the adrluctor muscle of the shell. Buth the anteriorly and the prosteriorly situated part of the borly can therefore be freely moved, and several muscles may be seen passing from the llorsal ligament hoth backwards and forwards. The bodr permits of being naturally dividel into two principal sections, which form more or less of an angle with we another, and whose limits are indieated by the dorsal ligament and the adductor muscle. The section situaterl in front of these parts is much smaller than that lying behind, and can lie again divided into 2 sub-sections, separated from one another ahove by a deep hollow. The fore part is the head projer, the hack part, the su-called cervical segment. The extremely mobile section situated behind the dorsal ligament and the adductor muscle, is also capable of being divider into two, - the body proper (trunk) and the caudal part, the first of these being of very considerable size, the second, quite short.

of the exterual appenrages, the liead carries the 2 pairs of antennx, and is continued backmards 
Paa Græudsen mellem Hovedet og Nakkesegmentet ligner de 2 kraftige Kindbakker og tat bag dem pa Bugsiden de 2 Par Kjover. Truncus brer 22-24 Par Branchialfodler og er delt i et tilsrarende Antal meget miforme Segmenter. Haledelen er nden egentlige Lemmer, men hrer par spidsen 2 starlse, beragelige $K$ lor og dorsalt 2 smaa jernsidesstillede Borster.

Jeg gaar nu over til at beskrive ethrert af disse Afsnit noget noiere.

Horedet (se Tah. XV. Fig. 2, 3, $t$ ) er forholdsvis af ringe Stor'else $0 g^{\prime}$, seet fra Sillen ${ }^{-}$(Fig. 2), af nregelmassig triangular Form. Dets dorsale Flade Pr jernt convex og barer i Widten et eiendommeligt stilket, noget kolleformigt Appendix (af), som ialmindelighed er tydet som et Fastheftningsredskal. Pandedelen er stærkt fremspringende, nasten konislit udtrnkket, og ender i en stump Spids, indenfor hvilken de sammensatte Oine har sin Plack. Nedenfor Pandedelen har Hovedet en dyb vinkelformig Indbugtuing, hvorved Pandedelen meget skarpt sondres fra det triangulart fremspringende Rostrum. Dette sidste er noget trekantet $i$ Gjennemsnit, idet ret oventil hav en tilskjarpet Kant, medens det nedentil er sragt indhulet langs ad Midten. Bunden af Indhulingen viser sig, naar Hovedet sees fra Siden, som en buet Linie, der strækker sig fra Spidsen af Rostrum bagover mod Basis af Overlaben. S'eet oventia (Fig. 3) eller nedenfra (Fig. 4), viser Hovedet sig temmelig bredt bagtil, men afsmalnes hurtigt fortil mud den smalt tilmudede Pandedel.

Nakiesegmentet er orentil sondret fia Horedet ved en meget distinct og temmelig dy Indbugtning, i hris Bund der larter sig paarise en tydelig trargaaende Sutur (se Fig. 3), der ender til liver Side med et lidet stærkt chitiniseret Fremspring, hrortil Kindbakliernes ovre Ende er articuleret. Den dorsale Del af Segmentet er strikt livelret og næsten af samme Længde som Hovedet, hrolimol den rentrale Del er meget kort og kun indskrenket til Mellemrummet mellem Kintbakkerme og skallens Iakkemuskel.

Den egentlige Krop (truncus) (se Fig. 1) er over dobhelt saa lang som re 2 foregaaende Afsnit tilsammen og næsten cylindrisk af Form, eller kun ganske sragt afsmahnende bagtil. Den er delt i en Række meget unitorme Segmenter, hvert bærende et Par Branchialfodder. Antallet af Segmenter er hos fuldroxne Indiviler, i Orerensstemmelse med Branchialfoddernes Tal, 22-24, hvoraf dog det hagerste sadvanligvis er nfuldkomment sonclret. Alle Segmenter, med Undtagelse af de allerforreste, har oventil et Knippe af bagulkmmmede Borster, mest ulviklede paa de bagerste Segmenter. Nogen tyde- on the muler side in the form of the labrum. On the bommlary between the head and the eervical segment lie the 2 powertul mandihles, and immediately behind them wn the ventral side, the 2 pairs of maxilla. The trunk wries trom 22 to 24 pains of branchial legis, and is dividerl into a convesponding number of rery uniform segments. The candal section is withont any true limbs, but carries at the extremity 2 strong, movable claws, and dorsally "2 small, inxtajosed bristles.

I will now pass on to describe each of these sections more fully.

The head (see Pl. XV, figs. 2, 3, t) is of romparatively small size, and, seen from the side (fig. 2), of an irregular, triangular shape. Its dorsal surface is evenly convex, and carries in the middle a pernliar, stalked, somewhat chb-shaped appendage (at) which is nsually interpreted as an orgun of attachment. The frontal part is very prominent, almost conically diawn out, and ending in a blunt point. within which the compound eyes are sitnated. Below the frontal part, the head has a deep angular indertation. wherely the frontal part is very sharpuly divided from the triangnlarly projecting jostrum. The latter is somewhat triangular in section, laving above a sharp elge, while below it is slightly hollowed out along the middle. The bottom of the groove appears, when the hearl is seen from the side, like a curred line extending from the point of the rostrum backwards towards the base of the labrum. Seen from above fig. 3) or fiom helow (fig. 4), the hear looks rather broad at the bark, but tapers midly in tiont towarls the narrowly rounded frontal part.

The cervical segment is separated above from the head by a very distinct and rather deep hollow. at the bnttom of which may be traced a distinct transverse suture (see fig. 3) ending at earl sille in a highly uhitinised pocess, to which the npper ends of the mandibles are articulated. The dorsal part of the segment is considerably ranlted, and of almost the same length as the head, the ventral part, on the other hand, being rery short, and confined only to the space between the mandibles and the adiuctor muscle of the shell.

The body proper (trunk) (see fig. 1) is more than twice as long as the 2 preceding sections together, and almost cylindrical in shape, or only ver slightly tapering behind. It is divided into a series of rely uniform segments, each bearing a pair of lnanchial legs. The number of segments in finll-grown indivituals corresponds with the number of branchial legs, viz from 22 to 24 , of which, howerel, the lindmost is generally imperfectly defined. All the segments, with the exception of the verr foremost ones, have a bunch of hackwardcurved bristles above, those on the hindmost seg- 
lig ndpræget Sondring af Midtlirop og Bagkrop findes ilike. Men, i Lighed med hrarl ri har gjort med Lopidums, lader sin masklie Græulsen mellem begge sæette red det 11 te Sogment, der hærer det bagerste at de 3 Par Branchialfodder, hris Exopoditer er omfrimede til Frste for Egmassen, og hror ogsaa Kjonsaabningerne lar sin Plads

Haledelen (se Trb. XVI, Fig. i) el ganske kort, nsegmenteret, og omboiet morl Bugsiden. Den er i sin forreste Del temmelig tyk, men udvides bagtil mor Enden til 2 trnde, jernsidesliggende Plader, cler hver nedar springer frem i Form af en tornformig Fortsats. Ovenfor denne Fortsats er Randen af hver Plade delt $\mathrm{i}$ et noget rekslende Antal (fra 8 til 15) smaa tandtormige Fremspring cilierede i Kanteme. Hror Plademe ophorer oventil, er der i Midten en liden Kinude, hrorpa er frestet 2 fint ciliererle 2-leddede Borster (Haleborsterne), og ovenfor dem igjen er den stærkt convexe, næsten hælformigt fremspringende Rygflade af Halen bevæbnet med omkring 6 stærke bagulboiede Torne, fint tandede i Kanterne, og ordnede i 2 megehnessige Rader (se ogsaa Fig. T, bis). Til den afstmmede Ende af Haledelen er hevægeligt indledtede 2 særdeles lange og stærke, men kun ganske svagt boiede Klor (Halekilorne), (ler morphologiskt synes at svare til Haletraadene hos Apodideme og ilen saakaldte Furea hos Branchipoditer og Phylloctrider. De afsmalnes gradris mod Enden, som gaar ul i en fin suids, og har langs den bagre, noget concave Side talrige smaa Tagoger samt desuden i sin basale Del et Antal af tine Borster.

De sammensatte (ine (se Tab. IT, Fig. 2, 3, 4, o) har, som ovenfor nevernt, sin Placls i det indre af den koniskt fremspringende Pandedel, hvis stumpt tilrundede Ende de nasten fuldstrudligt udfylder. De ligger meget nær summen og stodex endog hos fuldvoxne Individer umiddelbart til hinanden i Midtlinien (se Fig. 3, t). Seet fra Silen (Fig. 2) har hvert Oie en fuldst,ænlig cirkelrund Form, hrorimod de, orenfra eller nedenfira seet, viser sig paatrars wale. Begge Oine er ise Tab. XTI, Fig. 10, o) ommirne at en folles tynd og g.jememsigtig MLmbran "og lestarn af" et meget betydeligt Antal af Synse]ementer, hris ydre Del, com sadranlig, har Formen af sterkt lybirylende liorte Kegler indplantede med sinspirls $\mathrm{i}$ let morkerriepigment. Dette sidste har on noget lysere overfladisk skilit, hvorfor Krystallipglerne indentro Kanteme af olet tager sig red patifiklemcle Ly's ud som tart sammen liggende regelmaxnig morke Pletter, medens de i Peripherien dammer ell kiar Pram, eller Indfatning om Giet. (Yinene er til en vis tranl bevagelige, illet de dels kan trokke. noget tilhage i Huredet, dels noget ments being the most highly dereloper. There is no distinctly-marked division of the mesosome and metasome; but as in Lepidurus, we may perhaps place the boundary between the twn, at the 11th segment, which carries the hindmost of the 3 pairs of branchial legs whose exopodites are transformed to support the egg-mass, and where, too, the genital openings are situated.

The caudal part (see Pl. XVI, fig. $\tau$ ) is quite short, unsegmenterl and curved towards the rentral surface. In its anterior part it is rather thick, but expands posteriorly towards the extremity into 2 thin, juxtaposed lamellæ, each of which projects below in the form of a spiniform prominence. Above this prominence, the margin is divided into a somewhat varying number (from $S$ to 15 ) of small dentiform projections with ciliated margins. Where the lamellæ end above, there is, in the midcle, a little tubercle, to which are attached 2 finely-eiliaterl. 2-jointed bristles (candal bristles), and above them again is the highly ronvex, almost heel-like, projeeting dorsal surface of the tail, armed with about 6 strong. backward-curved spines, finely dentated at the edges, and arranged in 2 irregnlar rows (see also tig. 7, bis). To the blunt end of the candal part, 2 particularly long and strong, but only very slightly curved claws (eaudal (claws) are movably articulated; they seem, morphologically, to correspond to the candal filaments in the Aporticte. and the so-called furea in the Branchipatide and Phyllocaride. They taper gradually towards the extremity, which is rery finely pointed, and along their posterior, somewhat roncave sinle they are clothed with numerous small teeth, and moreover in their basal part with a momlser of fine bristles.

The compomul eyes (see Pl. XV, figs. 2, 3, 4, o) are situated, as already mentioned, inside the conically projecting trontal part, almost filling its bluntly rounted ent. They lie very close together, and even towch one another in the merlian line in finlgrown animals (see figs. 3, 4). Seen from the sile (fig. 2), each eye has a perfectly circular shape, whereas seen from above or below, they appear transversely oval. Both eyes (se Pl. XV1, fig. 10, o) are surrounded by a thin and transparent common memlnane, and consist of a very considerable mumber of risual elements, whose outer part has, as usual, the shape of short, highly-refractive cones. with their point planted in the dark ocular pigment. 'This pigment has a rather lighter superficial crating causing the crystalline cones within the margin of the ese to appear, when the light falls npon them, like closely-adjacent, regular, rlark spots, while those in the periphery form a clear rim or setting round the ere. The eres are movable to a certain extent, being partly capable of slight retraction into the head, partly of heing slightly turned on their axis. 
dreies om sin Axe. Dette sker red Hjwly af' 3 tyude Inskler. der fra Horedets Integument passerer bagfra fortil til hrert Oie (Fig. 10, m).

Det enkle Gie (Tab. XV, Fig. 2, 4, oc') ligger i en temmelig betrdelig Afstand fra de sammensatte oine, lige red Basis af Rostrum, og har, seet fra Sirlen (Fig. 2) en trekantet Form, med den ovre Ende spidst ndtruklet. Ted noiere Undersogelse (se Tab. XVT, Fig. 11, 12, 13) viser det et noget prismatiskt Udseende, idet man paa det kan adskille 4 Flader, begrendsede ved skarpe Kantro og hrer indfattet af en smal Stribe af morkerodt Pigment: 2 fortil sammenstodende Sideflader, en hagre Flade og en nedre Flade. Den sidste er den nindste, de 3 orrige ontrent af ens Storrelse. Alle Flader viser $i$ risse Belysninger en strert iriscerende Glands, men tager sig ialmindelighed red direkte paafaldende Lys opakt livide nd Det enkle oie en holdt i Situs ved 2 tynde strengformige Liganenter. hvoraf det ene passerel fra den spidst udtrukne ovre Ende af Organet skraat opad ind i Hoverlets Pandedel, og faster sig her til en liden grubeformig Fortykkelse af Integumentet lige muder de sammensatte Oine. Det andet ligament ndgaar fra Forkanten af den nedre Flade og begiver sig direkte ind i Rostrum, lrvor det oploser sig i flere korte Smaagrene, liver endende med en liden knaplormig Fortykkelse (se Tab. XV, Fig. 2, Tab. XVI, Fig. :).

Forste Par Folere (Tah. XV, Fig. 2, 3, 4, a ${ }^{1}$, Fig. 5), der udspringer til hrer side red den nertre Del at Hovedet, bag Rostrum, er mindre rudimentrere end hos de $\mathrm{i}$ det foregaaende beskrevne Phyllopoder, og nasten af Hovedets Lrengde. De bestaar hrer (se Fig. 5) af en kort Basaldel og en smalt kolleformig Endedel, ler i Forkanten viser" et noget vexlende Antal (fra 5-8) afrundede Jappe, hroraf de "z yderste indtager Spidsen af Foleren. Alle disse Lapje el tat besatte med sma Ingtepapiller, som red struk Forstolrelse (Fig. (i) riser sig at bestaa af en kort, skarpt kontmrelet Stilk og en serdeles delikat cylindrisk indedel, forsynet strax inlentor Spirlsen med en lilen giennemaigtig Blare. Prof. Lilljeborg har troet at finde paa Endedelen at Foleren et Antal af fine Trarsutmer, saaledes ordnede, at egentlig' enhver af de laterale Isappe skulde tilhore et sarskilt Led. Jeg har dog ikke paa de af mig undersogte Exemplarer kumnet med Sikkerhed paavise en saadan Leddeling, som lerimod hos visse Arter af Estheria er meget tyoligt mipræget. Verl Hjæl s af nogle tynde Muskler, ller fra Hovedet passerer ind i Basaldelen kan disse Fulere til en ris Grad bevæges frem og tilbage.

Andet Par Folere (Tab XT1, Fig, 1) er megtigt ndriklede og forestiller Dyrets rasentligste Bevageorganel. De ndspringer med en lued Basis fra
These movements ale accomplished by the aid of 3 thin mmscles, which pass from the back of the integument of the head, forwards to each eye (fig. $10, \mathrm{~m}$ ).

The ocellus (Pl. XV, figs. 2, 4, oc) is sitnated at rather a considerable distance from the componnd eyes, close to the base of the lostrum, and, when seen from the side (fig. 2), exhibits a triangular shape, with the mprer end drawn out acntely. On closer observation (see Pl. ITI, figs. 11, 12, 13), it presents somewhat of a prismatic appearance, 4 sm. faces, bomnded by sharp edges, and each bordererl by a llarrow band of dark-led pigment, being wistinguishable, viz, 2 lateral surfaces meeting in front, 1 posterior surface, and 1 inferior. The last is the smallest, the other 3 of almost uniform size In certain lights, all the smifaces have an irjdescent lustre, but generally appear opaquely white under directly falling light. The ocellus is kept in posi. tion by 2 thin cord-like ligannents, one of which passes from the acutely dramm-ont end of the or gan, obliquely upwards into the frontal part of the head, there attaching itself to a small pit-like thickening of the integument, just below the compround eyes. The other ligament issues from the anterior edge of the inferior surface, and proceeds directly into the rostrum where it is resolved into sereral short ramuli, each telminating in a small bud-like expansion (see Pl. XV, fig. 2; PI. XVI, fig. !)

The first pair of antenna (Pl. XV, figs. 2, 3, $4, \mathrm{a}^{1}$. fig.5), which spring out to each sile from the lower part of the head, hehind the rostrum, are less rudimentary than in the previonsly-described Phyllopods, and ale almost as long as the head. They each consist (see fig. 5) of a short basal part and a narrow (lub-like terminal part, on whose front margin is a somewhat varying number (from 5 to s) of rounded lobes, of which the two outermost accupy the point of the antemua. All these lobes are thickly set with small olfactory papillar, which, when highly magnified (fig. (i) prove to consist ot a short, sharplydefined stalk, and an exceelingly delicate cylindrical terminal part, provided, just within the point, witl a small, tramsparent resicle. Prot. Lillieborg states having found a number of fine transverse sutmres. so arranged that each of the lateral lobes belongs to a separate joint. I have not, howerer, in the specimens I have examined, been able to make ont with certainty such an articulation, which, on the other Irand, is very distinct in certain species of Estheria. By the aid of some fine nuscles, which run from the heal into the basal part, these antemne ran to a certain extent be noved backwards and torwarls.

The ond pair of antemne (Pl. IVI, fig: 1) al' powerfully developed, and they constitute the animal's principal organs of locomotion. 'They issue 
Siclefladerne af Horedet (se Tab. IV, Fis. 1), og bestaar liver af et crlindriskt, mulsulost Skaft og ?stærkt torlængede (rrene. Nkattet viser red Basis en noget albuformig Boining og er her i Bagkanten forswnet med et lidet borstebesat Fremspring (se ugaa Fig. 3, a ${ }^{3}$ ). Dets rdre Del er meget boielig og delt i ontrent i liorte segmenter tret besatte fortil med strrke, pigtormige Borster. Grenene er meget smale og af meget betrdelig Langle, navulig den inclre eller bagre, der er nrer dobbelt saa lang som Skaftet. Begre Grene er delte i taluige fra 10 til 14), meget sliarpt afsatte og noget sliveformige Led, lnvoraf livert i Bagkanten har Here lange, "-leddede og fint cilierede Srommeborster, i Forkanten ligelerles et storre Antal at strerke, i Enden noget hageformigt linmmede Pigge. Fartel Grenenes indbyrles Længrle som Antallet at Led paa liver Gren er forovigt noget varierende los forskjellige Inclivider.

(verlaben (Tab. NT, Fig. 2, 4, L, Fig. T) ud gaar bagtil som den middelbare Fortsættelse at Hovedets rentuale Ile], og livelrer sig jaa Undersilen ul orer Kindbaklienes Tyggedel, samt nar med spidsen ind mellem Basis af lste Eudpar (se Fig 1). Jen er imidlertid til on ris Grarl beragelig, illet den ved to tronde til dens Basis lobemde Mukkler kau loftes noget af fra Mnnddelen og igjen red andre Inskler presses tret ind mod samme Af Form er den nasten halroylindrisk, med den nedadvendte Flade starlit ronvex, den ovre noget concav. Ted Enden indsnareses den pludselig, damende til hrer side et vinkelformigt Hiorne, og forlanger sig til en meget boielig og i Enden tint cilieret sipuis. () venorer denne tentakelformige Fontsats har den en skiveformig, lodret stillet Endelamelle, der læg' ger" sig ind mellem de 2 Par Kjaever, naar Orerlrben presses ind mod Legenet. I Orerlabens indre sees flere celleagtige Legemer, der synes at være at kjertelagtig Natur, og ligelerles et storre Antal trærgaande Inskliler, der virker pa dlen blode ovre Flade og rimeligvis har Betylning rerl sivalgnings. processen.

Kindbakkerne (Tab. IV, Fig. 2, 3, 4, $\mu$, Fig. S), der som 2 Boiler omfatter siderne af Legemet paa (irandsen mellem Hovedet og Nakkesegmentet, er meget linatigt milviklerle og hos det voxne Ty nuen rthrert spor af Palpe. Den spidst udlobende orre Fnde af det loaadiormige Corms er beregeligt arti"mleret med en liden knopformig Fortykelse af Integumbitet ved liver Ende at den Trassutur, som tindes i Innnden at den dorsale Indhngtning mellem Hovedut ug talikesegmentet. 'Prgodelen el statkt indboiet og sondret fral (orums red eu tyrlelig Inr. knibning pller Hals. Den ender, som hos Branohipodiderne med en lired, fint rittet Tygretlade uden from the lateral surfaces of the heal, with a broad base (see Pl. IV, fig. 1), and each consist of a eylindrical, muscular scape, and two greatly elongated rami. The scape exhibits at the base a somewhat elbow-like bend, and on the hind margin at this point, is furnished with a little setons projection (see also fig. 3, $\mathrm{a}^{2}$ ). Its distal part is very flexihle, and livided into abont 8 short segments, thickly clothed in front with strong spiniform bristles. The rami are very narrow, and of considerable lengtl, notably the inner or hinder one, which is more tlian twice as long as the scape. Botl rami are divided into numerous (from 10 to 14) very clearly defined and somewhat lamellar joints, each of which has several long, li-articulated and finely ciliated natatory bristles in the lind margin, and a large number of strong, rather luamons slines in the front margin. Buth the mutual length of the rami, and the number of joints in each ramus, varies somerliat in different specimens.

The labrum (Pl. XV, figs. 2, 4, L, fig. 7) projects backwarls as the immerliate continuation of the rentral part of the hearl, and on its inferion side arches over the masticatory part of the mandibles, its point extending in betreen the base of the first pair of' legs (see tig. 1). 'T'o a certain extent, however, it is morahle, for it can be raised a little from the oral parts by two thin muscles rumning to its base, and again. by other muscles, aan be pressed close in against those parts. In shape, it is almost semi-cylindrical, witl the down-turned surface rery convex. At the extremity it is suddenly contracted, forming on each side a sharp corner, and heing produced to a rery Hexible point, finely ciliated at the extremity. Above this tentacular projection there is a discoid, rertically-situated, terminal lamella, which is interposed between the 2 pairs of maxillæ, when the labrum is pressed in towards the bouly. In the interior of the labrum are visible several cell-like bodies, which appear to be of a glandnlons natnre, and also a large number of transverse muscles, which act upon the soft upper surface, and probably perform a part in the process of strallowing.

The mandibles (Pl. XV. figs. 23, 3, 4. $\mu$, fig. s) which embrace the sides of the body like 2 bows. on the boundary-line between the heal and the cervical segment, are very powerfully dereloped, and, in the finll-grown animal, without a trace of palpi. The pointed upper end of the boat-like body is morably articulated with a small bud-like thickening of the integument at each end of the transverse suture fouml at the bottom of the dorsal hollow between the head and the cervical segment. The masticatory jart is very much inemred, and separated from the corpus by a distinct constriction or neck. It encls, as in the Branchipodicle with a 
Spor af tandformige Fremspring. Foruden de liraftige Adductormuskler. der fylder Storsteparten af den indre Hullied af Corpus, sees ogsaa en Del andre IInskler at passere til Kindbakkerne, ved Hjæly af hrilke disse kan dreies $1 \mathrm{~m}$ sin Axe inden visse Græulser. De strokeste af clisse Rotationsmuskler udspringer fra den torsale Flade af Nakkesegmentet og convergerer mod Kindbakkernes bagre Side (se Fin. 2). Nogle betydelig mindre Muskler passerer fra Horedets dorsale Integument til Forsiden af Kindbakkerne.

Nogen Undcrlabe har det ikke lykkets mig at paavise. Prof. Lilljeborg tror dog at have fundet den i Form af' 2 meget smar tilspidserle og tret haarede Lappe.

Forste Par Kijwer (Fig. 2, 4, 9, $m^{1}$, Fig. 10) bestaar af en kort og tyk Basaliel og en meget berregelig indadboiet, skiveformig Endedel, der paa sin trie Rand er besat med en txt Rad af tynde, leformigt lirummerle Borster, alle tydeligt 2-leddede og fint cilierede. Fornden dem findes der endnu en Rad af betrdelig liortere Borster eller Pigge, der er grovt tandede $i$ Kanterne og ender i en særeleles fin og delicat Spinls (se Fig. 11). Inisse Borster er dog kum indskrænkede til clen bagre Halvdel af Randen. Endelig bemærkes fortil, i Vinkelen mellem Basaldelen og Endelamellen en meget liden, men tydeligt begrændset, secundre Lamelle af smal tungedamnet Furm og kantet metl nugle ganske korte Borster.

Andet Par Kijerer (Fig. 2, 4, 9, m², Fig. 12, 13) er betydelig mindre end 1ste Par og, som det srnes, kun lidet bevægelige. De bestaar ligeleiles af en fort Basaldel og en indadrettet Endelamelle af elliptisk Form, med det indre afrundede Hjorne betydelig mere fremspringendle end det ydre. Lamellen er kantet med omliring 24 tret cilierede Borster, som $\log$ er utydeligt ledulede $o g$ kun mod det indre Hjorne naar nogen betydelig Lengde.

Af Fodder har jeg hos fuldt udviklede Individer" talt 22-23 Par. Prot. Lilljeborg har hos nalminclelig store Exemplarer endnu fundet et Par bag disse, saa at deres Tal kan stige til 24 Par ialt; ja Grube paastaar endog lios et Individ at lave talt 26 Par. De er idethele af en meget milorm Bygning og viser alle Characteren at regte Branchialfodder. Foruden til Respiration, har de imidlertil ogsaa en væsentlig Betydning vell Næringsoptagelsen, idet de i Vaudet værende organiske smaadele, hroraf Dyret nærer sig, red Fodlernes rhytmiske Bevægelser bliver hvirvlet ind mod Munddelene. De 10 eller 11 forreste Par er nogenlunde af samme Langde, men fra det 11te Par begynder de stærkt at aftage i Storrelse, og de allerbagerste Par er overmaade smaa og vanskelig at tælle. De har alle broad, finely-fluted molar surface withont a tracos uf dentate projections. Besiles the powerful anlinetor muscles, whish fill the greater part of the immer eavity of the boly, a few other muscles are also seen passing to the mandilles, which, by their aid, can turn upon their axis within certain limits. The strongest of these rotatory muscles issue from the dorsal surface of the cervical segment, and converge towards the posterior side of the mandibles (see fig. 2). Some much smaller museles pass from the dorsal integument of the hearl to the anterior side of the mandibles.

I have not succeeder in proving the presence of any posterior lip. Prof. Lilljeborg, however, believes that he has found it in the shape of two very small, pointed, and densely lairy lobes.

The first pair of maxille (figs. 2, 4, 9, $m^{1}$, fig. 10) consist uf a short and thick basal part, and it rex'y movaljle, incurved, lamellar, terminal part, which is clother on its free margin with a close row of thin, talriformly curved bristles, all distinctly Q-jointed and finely ciliated. In addition to these, there is yet another row of much shorter bristles or spines, which are coarsely dentated at the eilges, and end in a particularly fine and delicate point (see fig. 11). These bristles, lowever, are only confined to the posterior halt of the margin. Lastly, there is visible in tront, in the angle between the basal part and the terminal lamella, a very small, but distinetly defined lamella, of a narrow lingular form, and edged with a few rery short bristles.

The 2nd pain of maxille (fig's. 2, 4, 9, $m^{2}$, figs. 12, 13) are considerably smaller than the first pair, and apparently only slightly movable. They also consist of a short basal part, and an inward-directed terminal lamella of elliptical shape, with the imer rounded corner considerably more prominent than the outer one. The lamella is bordered with about 24 thickly aliaterl bristles, which are however, indistinctly axticulated, and only at the inner corner attain any consiclerable length.

In firlly developed animals, I have counted from 2.2 to 23 pairs of legs. Prof. Lilljeborg has even found a pair behind these in mnsually large specimens, so that their mumber can rise to 24 pairs in all; incled, (irmbe asserts that in one specimen he has connted as many as 26 pair's. They are, on the whole, of a very uniform structure, and exhibit all the characters of true branchial legs. They are, howerer, of essential importance, not only in respiration, lont also in the achission of nourishment, as the organic particles in the water, on which the animal feeds, are whirled in towards the oral parts by the rliythmical movements of the legs. The 10 or 11 foremost pairs are of about equal length, but after the 11th pair they begin to diminish rapidly, the hindmust pairs being exceedingly small and 
(:e Tab. I TI, Fig. 3) Formen af nedadrettede aflange, noget buede og uregelmæssigt fligede Plader, hvis convexe sicle render fortil, den concave bagtil, og som i Kanterne er rigeligt borstebesatte. Man kan pra dem adskille de samme 3 Hoverdele som hos andre Branchiopoder, nemlin Endopodit, Exopodit og Epipodit. Endopoditen, ellev den egentlige Stamme, low ved Basis indad en meget tydeligt sondret Coxallap (mx) af temmelig compliceret Brgning (se Fig. 1). Den er noget skraat indadrettet, af stmmpt honisk Form og meget rigeligt forsynet med Borster. Ted Spidsen har den 2 korte Pigge, og en lignende Pig findes ogsaa paa den indre Side. Fra deme sidste Pig strækker sig en noget skrat lobende Rad at lange, leformigt indad krummede Borster, der alle er tydeligt 2-ledclerle $o g$ fint cilierede. En anden Rad af cilierede Borster strakker sig langs den ydle Kant af Coxallappen, men disse Borster er ikke leformigt krummede og aftager hurtigt i Lxugde mod spidsen. Umiddelbart oventor dem ndgaar fra Iderkanten en noget stærkere, siraat indadrettet Borste. Den indre Kiant af Endopoditen ex ved smaa Indsnit delt i + korte og brede Lapue (Enditer), der barer en dobbelt Rad af fint cilierede Borster, hvoraf de i len ene er særdeles lange, tydeligt 2 -leddede $0 \mathrm{~g}$ bagudboiede. Den rderste af disse Lappe er noget mere tremspringende end de ovrige, og til dens ydre side er articnleret en smal tungeformig Lamelle, rundt om besat med cilierede Borster. Deme Lamelle forestiller den rlerste (ote) Endit, eller Endopoditens Endeled, det eneste tydeligt begrændsede Led paa Foden. Epipoditen (ep) har Formen af et aflangt ovalt, noget sakformigt Alpendix, uden ethvert Spor af Borster. Den el frestet til Idersiden af Endopoditen i en kort Afstand fra dennes Basis og rettet lige opad over Sileme af Kropren (se Tab. XV, Fig. 1). Exopoditen (ex), der udspringer med en bred Basis ligeledes fra Ydersiden af Endopoditen og middelbart nedenfor Epipoditen, r af betrdelig Storrelse og delt i smale i forskjellig. Retuing udgasende Lappe, en rentral og en dorsal. Den ventrale Lap rækker ontrent til Fpirsen af Endopoditens Endelimelle, og er ligesom denne rundtom kantet med cilicrede Borster. Den dorsale Laj (ex $x^{1}$ er betydelig mindre end den ventrale, neppe overragende Epipoditen, og er borstebesat alene $\mathrm{i}$ den Irdre Kant. Par ade til 11te Fodpar er imidlertid los fuldt udviklede Individer (se Tab. XT, Fig. 1) denne Lap ndtruklet til en meget lang traadformig Fortsats, rer rager op i Skallens dorsale Cavitet, hror den tjencr til Freste for den her sig ansamlende Egmasse. wale eller sidste Fodpar (Fig. 5, b) sliller sig i visse Henseender kjendeligt fra le ovrige. Det er scerleles lidet og har Endopoditen ganske kort, med linn 3 Lappe indarl, formden Coxallappen. Borsteme paa disse Lajpe, sarvelsom paa det korte, diffient to eomnt. They all (see PI. IVI, fig. 3) have the shape of down-pointing, oblong, somewhat curved, and irregularly lobed laminx, whose convex side turns to the front, the concave to the back, and whose edges are thickly elothed with bristles. The same 3 principal parts can be distinguished in them as in other Branchiopods, namely, endopodite, exopodite and epipodite. The endopodite, or stem proper, has on the inner side of the base a very distinetly-defined coxal lobe of rather complicated structure (see fig. 4). It is direeted rather obliqnely inwards, is of a bluntiy eonical shape, and abundantly provided with bristles. At the point it has two short spines, and a sinilar spine is also found on the inner side. From this last-mentioned spine, lums a rather oblinue row of long, falciformly incurred bristles, all distinctly 2-jointed and finely ciliated. Another row of ciliated bristles runs along the outer edge of the coxal lobe, but these are not falciform ly curved, and they rapidly decrease in length towards the point. Immediately abore them, there issues from the onter edge a somewhat stronger Inistle, directed obliquely inwards. The inner edge of the endopodite is divided $b \mathrm{v}$ small indentations into 4 short, broad lobes (endites) carrying a double row of finely ciliated bristles, which in one row are particularly long, distinctly 2 -jointed, and bent baek warks The ontermost of these lobes is rather more projecting than the others, and to its outer side is articulated a namow lingular lamella, edged all romd with eiliated hristles. This lamella represents the ontermost (5th) endite, or the terminal joint of the endopodite, the only distinctly defined joint in the leg. The eppipodite (ep) is in the sliape of an oblong oval, somewhat sac-like appendage, with no trace of bristles. It is attached to the outer side of the endopodite at a short distance from its base. and is directed straight upwards over the sides of the body (see Pl. XI', fig. 1). The exopodite (ex), which issues with a broad base also from the onter side of the endopodite, and immediately below the epipodite, is of considerable size, and is divided into 2 narrow lobes, one rentral and one dorsal, projecting in opposite divections. The ventral lobe reaches almost to the point of the terminal lamella of the endopodite, and is likewise edged all round with riliated bristles. The dorsal lobe $\left(e x^{2}\right)$ is considerably smaller than the rentral, searcely reaching beyond the epipodite, and is edged with bristles only on the outer margin. (on the sth, loth and 11th pairs of legs in fully-developed speeimens, however see Pl. XY, fig. 1) this lobe is drawn ont to a very long filiform projection, which extends up into the dorsal carity of the shell, where it serves as an attachment for the accumulated egg-mass there. The $23 r$ w last pair of legs (figs. 5 and 6 ) is conspicnonsly distingnished in certain respects 
afrundede Endeled er meget redncererle i Antal. Epiporliten er overmatrle liden og rudimenter, hyorimod Exopoditen er furholdsvis vel udvililet, naaende med sin ventrale Lap langt ud over Endopoditen. Den er kantet med omtrent 23 Borster at' noget nlige Langle. Meget lignende, skjondt endmu noget simplere, er Bygningen af let 2 the Par lins meget store Exemplarer, saaledes som dette er beskrevet og afbildet af Prof. Lilljeborg.

Legemets Farve er hos fuldroxne Exemplarer mere eller mindre trdelig olivengron, gaaende paa Bugsiden og paa Foddeme over til gulrodt. Selve Skallen er lyst hornfarvet og temmelig gjemnemsigtig, log meget constant med Dorsalkanten af en ret ioinefaldende mork graasort Farve.

\section{Indre 0raner.}

Paa Grund af denne Forms store Gjememsigtigherl, vil den indre Organisation ret vel kunne studeres, navnlig paa levende Exemplarer, tildels ogsaa paa vel preserverede Spiritusexemplarer, uden at nogen Dissection strengt taget er fornoden. Kun hvor det gjælder en mere detailleret (histologisk) Undersugelse af Organeme, vil det være nyttigt at skride til en Sonderlemmelse af Dyret.

Med den sædvanlige Indleirings- og snitmethorle kommer man ikke svonderlig viclt, og denne i vor Tid $\mathrm{i}$ sa stor Udstrekning anvendte T'ndersogelses. methode synes idethele at være lidet anvendelig, hvor det gjielder Krebsdyr.

Fordøielsesapparat. - Tarmen strækker sig som et nogenlumle jernt tykt Ror giennem hele Dyrets Legeme, og skimer meget tydeligt igjennem Integumenterne red dens sædvanligvis morlie Contenta (se Tab. XV, Fig. 1). Den ender i Halen med en kort, stærkt muskulos Endetarm, som ndmunder yaa Halens sids, mellem Haleklorne. 1 Nakkesegmentet gjor Tarmen en pludselig, næsten vinkelformig Boining nedad, i Overensstemmelse med Legemets stærke Krumning paa dette Sted. Tarmens hulhold er i demne forreste Del sædvanligris lysere, orangefarvet eller blegt gulagtigt. Spiseroret er ganske liort og passerer fra IInndaabningen lige fortil, hror det munder i Tarmens forreste Ende merl en i dens Lumen fremspringende noget ndvidet Del (se Fig.9, oes). I Forbindelse med Tarmen staar et temmelig voluminost og compliceret lijertelagtigt Organ (Fig. $2,3,7)$, der ndfylder en stor Del af Hovedets indre Hnle, og aabeubart svarer til den hos Lepidurus ligeledes i Hovedet beliggende Lever. Ligesom hos Lepichurs, bestaar Organet af 2 symetriske Halv- from the other's. It is very small, and its endopodite is quite short, with only 3 lobes inside in addition to the coxal lobe. The bristles on these luber, as also on the short rounder terminal joint, are greatly reduced in number. The epipodite is exceedingly small and rndimentary, whereas the exopodite is comparatively well developed, reaching far ont over the endonodite with its ventral lobe. It is edged with about 23 bristles of somewhat nnequal length. The structure of the 24th pair found in very large specimens, though rather more simple, is rery similar, as deseribed and figured by Prot. Lilljehorg.

The colonr of the body in full-grown specimens is more or less distinctly olive-green, merging into vellowish red on the ventral sicle and on the legs. The shell itself is of a light horn-colour, and tolerably transparent, though the dorsal margin is almost invariably of a very conspicnously darli grey colour.

\section{Interual 0roans.}

On aceonnt of the great transparency of this form, its internal organisation may lue very easily studied, especially in living specimens, to a certain extent too, in well-preserved spirit specinens, withont the necessity of dissection. Only when a more minnte (histological) investigation of the organs is to be made, will it be useful to resort to a dismembering of the animal.

By the ordinary imberlding and section method, not much information is to be gained, and this mode of investigation, now so widely employed, seems, on the whole, to be of very little use as regards Crustaceans.

Digestive System. - The intestine mus, in the form of a tube of fairly even thickness, throngh the whole borly of the animal, and is very distinetly seen through the integrments by reason of its generally dark contents (see I'l. XV, fig. 1). It teminates in the tail in a short, very muscular rectum, which opens out at the point of the tail, letween the candal claws. In the cervieal segment, the intestine makes a sudden, almost angular bend downwards, following the sharp curve of the body at that place. The contents of the intestine in this foremost part are generally lighter, of an orange or pale yellow hue. The cesophagus is quite short and passes from the oral aperture straight forwards, where it opens into the anterior end of the intestine by a somewhat expanded part projecting into its lumen (see fig. 9, oes). In conneetion with the intestine, there is a rather volnminons and complieated glaindular organ (figs. $2,3, l$ ) ocenpying. a great part of the inner carity of the heal, and evidently answering to the liver in Lepidurus, which 
dele som hyer ndmunder med en kort Udforselsgang noget lateralt i Trarmens forreste Del, og i sin Peripheri er delt $i$ talrige bugtede Blindsakke, ialmindelighed fylde med et intenst gultfarret Stof. Hrert Organ ndsender nedad en Sidegren, der i Hovedets rentrale Del, middelbart foran Basis af Overlæben, oploser sig i Alere nuegehmasige Trappe. Hovedmassen af Organet ligger dog dorsalt, hror det sammen med det tilsvarende Organ paa den anden Side danner en tilsyneladende sammenhængende Kalot oyer Tarmens forreste Del (se Fig. $2 \circ 3$ ).

Circulationsapparatet. - Hjertet se Tab. IV, Fig. I er beligremle ovenover Tarmen i den forreste Del af' Truncus, strækkende sig fortil ind i Nakkesegmentet, bagtil ind i det the fodbærende Segment. Det luar Formen af et fortil noget videre crlindristit Ror, aabent i begge Ender, og desurlen forsyet til hver side med + tydelige Spaltaabninger, 1 Par for Nakikesegmentet, de 3 orrige Par for de 3 forreste Segmenter af Truncus. Af nogen virkelige Blodkar har jeg ikle kumnet finde noget spor; men Blodet folger $\log$ nnder sin C'irculation i Lege. met visse meget bestemte Baner. Tla Blodlegemerne er meget tydelige, er det ikke saa vanskeligt paa tilstrakkelig giennemsigtige levende Exemplarer at studere de ræsentligste Træk af Circulationen, og jeg skal i det folgende i Korthed beskrive samme, saaledes som jeg har troet at finde den red gijentagne omhyrgelige Undersogelser. Fra den bagre Del af Legemet lommer en strek Strom af Blod, der folger liygsiden af Truncus og passerer direkte ind i Hjertet giemnem dettes bagre Aabning. Ted Hjertets Systule lukkes denne Aabning. saavelsom de laterale Spaltabininger, og Blodet stodes med stor liraft nd af Hjertets forreste Ende. En Tel af den saaledes af Hjertet ndliomme Blormasse passerer direkte ind $\mathrm{i}$ den forreste Del af Tegemet og torsvner Hovedet med dets forskjellige Tedhang med Blod. En auden Blodstrom boier pindselig om nuder Hjertet og lober bagover, nmidilelbart nedentor den tilforende dorsale Blodstrom, lige til Haledelen, hvor den synes at lonie om paa Bugsiden af Drret for at forsyne Branchialfodleme merl Blod. En Bdie betrdelig Del af den fra Hjertet udstodte Blodmasse passerer til hrer side mod skallens Lnkkemuskel, hvor den i Omkredsen af Huskelareaen trenger ind i selve Skallen. Herfra fordeles Blodet rundt on i de to Valyler, idet det i forskjellige Baner giennemstrommer det complicerede System af Hulrum, der. som ovenfor anfort, findes mellem disses 2 Lameller. Efrerat have circuleret i Skallen samler Blorlet sig hidt efter lidt i 2 dorsale Hovedstromme, der lober langs Rygkanten af Skallen, en ganklie kort forreste, og en betrdelig langere is there also sitnated in the head. As in Lepirnme. this organ consists of two symmetrical halves each opening by a short excretory duct somewhat laterally in the anterior part of the intestine, and divided in its periphery into numerons cæca, generally filled with a substance of an intense sellow colonr. Each organ sends down a lateral branch which is resolved into several irregular lobes in the rentral part of the head immediately in front of the base of the labrum. The great bulk of the organ, however, is sitnaterl dorsally, where, together with the corresponding organ on the other side, it forms an apparently continuons cap over the anterior part of the intestine (see figs. 2 and 3 ).

Circulatory System. - The heart (see Pl. XV. fig. 1) is situated above the intestine in the anterior part of the trunk, extending forwards into the cervical segment, and hackwards into the th pedigerons segment. It has the shape of a "ylindrical tube, rather wider in fromt, and open at both ends, and also furmisher at each side with 4 distinct ostia, one pair for the cervical segment, the other 8 for the 3 foremost segments of the trunk. I have been mable to find any trace of actual blood-vessels, but during its circulation through the body, the blood follows certain fixed comrses. As the corpmscles are very distinct, it is not difficult in sufficiently transparent living sperimens to study the principal features of the circulation, and I will here briefly describe them as I have found them by repeated careful investigations to be. From the hind part of the body comes a strong stream of blood keeping to the dorsal side of the trunk, and passing directly into the heart through its posterior aperture. This aperture, as well as the lateral ostia, is closed by the heart's systole, and the blood is ejected with great force from the anterior end of the heart. A portion of the quantity of blood thus issuing from the heart, passes slirectly into the anterior part of the bodr, and supplies the hear and its varions appendages with blood. Another stream of blood turns suddenly below the heart and flows backwards immerliately below the afferent dorsal stream right up to the candal part, where it appears to tmin to the ventral sile of the animal, in order to supply the branchial legs with blood. A third consilerable part of the quantity of blood ejected from the heart, passes on both sides towarls the adduetor mnscle of the shell, where, within the ciremference of the muscnlar area, it forces its way into the shell itself. From this the blood is distributed over the two ralves. flowing by varions conrses through the complicated system ot cavities which, as stated above, is found between their " lamella. After having circulated in the shell, the blond gradually collects in two principal, dorsal streams which $\mathrm{rm}$ along the dorsal enge of the shell, one quite short 
bagerste Strom. Begge morles ved det dorsale ligament, hvor de boier on indad og ultommer sit Blod, sammen med det fra Hoverlet tilhagevendende, $i$ den forreste Del af Hjertet gjemem lettes 1ste Par Spaltaabninger. De orrige $3 \mathrm{Far}$ Spaltaabninger srnes at optage det Blod, der, efterat have circuleret i Fodderne, vender tilbage til Hjertet.

Respirationsapparat.-- Rent morphologiskt maa ristnok Foldernes Epipoditer ansees som de egentlige Respirationsorganer, da de alsenbart svarer til Gjelleme hos hoiere Trebsdrx. Men da ogsaa de orrige Dele af Fodlerne riser en lignende overmaarle delikat Struktur, har man Grund til at antage, at Respirationen ikke er ndelukkende indskrænket til hine Vedhæng, men foregaar overalt paa Foddernes Overflade, hrad der ogsaa har givet Anledning til den almindelig benyttede Benærnelse Branchialfodler. Som let physiologiskt vigtigste Respirationsorgan maa vi dog utvivlsont anse selve Skallen, i hrilken der, som ovenfor anfort, finder en meget livlig Blodcirmation Sted. Ved Foddernes rhytmiske Bevagelser sker der nemlig en stadig Hornyelse af Vandet indenfor Skallen, og da dette Vand umiddelbart beskyller den sardeles delikate Membran, der beklreder. Talvleme indvendigt, synes alle Betingelser at være tilstede for at en hurtig Gasudrexling her kan ske med det indenfor Membranen strommende Blod.

Nervesystemet. - Den i Hovedet beliggende Del af Nervesystemet er ikke ranskelig at observere paa tilstræklielig gjennemsigtige Exemplarer. Den bestaar at det saakaldte ovre Srrelgoanglion, eller Hjernegangliet, med de fra samme udgaaende Nerver. Selve Hjernegangliet ex ikke af sprdeles betydelig Storrelse, og ligger (se Tab. XV, Fig. 2) temmelig langt tilbage i Hovedet, umiddelbart bag det enkle Oie, hrormed det forbinder sig med en temmelig bred Fortsats (se ogsaa Tab. XVI, Fig. 9, 10). Det lestaar, som sadvanlig, af 2 symetriske, med hinanden i Midtlinien forbmulne Halvdele, hroraf enhver er udtrukket i 2 divergerende, koniske Fortsatser. Fra le forreste Fortsatser udgaar de overordentlig lange og stierke synsuerver og desuden en ganshe liden Nerve for Oiemusklerne. Selve Synsnerverne passerer fortil ind i Hovedets Pandedel, hvor enhver af dem svulmer ul til et kolleformigt Synsganglion. Begge Ganglier ligger tat sammen, uden dog at smelte sammen, og deres Ender er kmn ubetydeligt fjernet fra de sammensatte oine (se Fig. 10). Fra dem udgaa talrige fine Nervefibre, der trænger ind i binene og forbinder sig med disses enkelte Synselementer. De bagre Fortsatser af Hjernegangliet ( ${ }^{1}$ ) er noget kortere end de forreste og mere udadrettede (se Fig. 10), men af en lignende konisk Form. De giver 13 - G. 0. Sars: Fauna Norvegix. anterior stream, and one comsiderably longer posterior one. 'They meet at the dorsal ligament, where they tmon inwards, and empty their blood, together with that ruming back trom the head, into the anterior prart of the heart through that organ's first pair of ostia. 'The 3 other pairs of ustia apjeas to receive the blood which, after having cilculated in the legs, returns to the heart.

Respiratory Organs. - From a purely morphological point of view, the epipodites of the legs must be considered as the true respiratory organs, as they evidently answer to the gills in higher Crustareans. But as the other parts of the legs also show a similar exceedingly delicate structure, there is reason to suppose that the function of respiration is not confined exclusively to these appendages, but is carried on over the entire sur face of the leg, a ciremustance which has given rise to the generally used term - branchial legs. As the physiologically most important organ of respi ration however, we must undoubtedly regard the shell itself, in which, as stated above, a rery active circulation of the blood goes on. Br the rhythmical movements of the feet, a constant renewal of the water inside the shell takes place, and as this water is in immediate contact with the peculiarly delicate membrane lining the interior of the ralves, all the conditions reyuisite for a rapid exchange of gas with the blood flowing within the membrane, appear to be present.

Nervous System. - That part of the nervous system lying in the head is not difticult to observe in sufficiently transprarent specimens. It consists of the so-called supra-cepophageal ganglion or cerebral ganglion, with the nerves proceeding from it. The cerebral ganglion itself is of no very considerable size, and is situated (see Pl. IT, fig. 2) rather far back in the head, immediately behind the ocellus, with which it is connected by a tolerably broad projection (see also Pl. XVI, tigs. 9, 10). It consists as usual of 2 svmmetrical halves connecter with one another in the median line, each half being drawn out into 2 divergent conical protuberances. From the foremost of these issne the exceedingly long and strong optic nerves, as also a very small nerve for the oonlar muscles. The optic nerres themselves pass forwards into the frontal part of the head, where they eacli swell ont into a club-like optic ganglion. These ganglia lie close together without howerer coalescing, and their extremities are at only a slight distance from the compound eyes (see fig. 10). Numerous lelicate nerve-fibres issue from them, entering the eres, and connecting themselves with the several visual elements of those organs. The lind protuberances of the cerebral ganglion $\left(\mathrm{a}^{2}\right)$ are rather shorter than the front ones, and directed more outwards (see 
Udspringet for Nerverne til 1ste Par Folere, nemlig pn meget tynd Nerve for de $\mathrm{i}$ Basaldelen af disse Folere indtrædende Muskler, og en betvilelig starkere Nervestamme, der passerer ind i den kolleformige Endedel og til enhver af de laterale Lappe ndsender tahige Fibrer (se Tab. XV, Fig. 5). Nerverne for 2det Par Folere $\left(a^{2}\right)$ udgaar ikke fra Hjemegangliet selr. men fra de fra samme bagtil udgaaende strerke Commissmer, der omgiver Spiseroret for at forlonde sig med Buggangliekjæulen. Man kan tydeligt adsille 2 saadanne Nerver af omtrent ens Tykkelse og udspringende tat sammen, noget foran Midten af Commissmerne, som paa dette Sted viser en ganske svag ganglios Opsrumning. Angaaencle disse Nervers videre Forlob ind i selve Foleme, har det dog ikke været mig muligt at skafle mig noget tilfredsstilenrle Begreb.

Den ovrige Del af Centralnervesystemet er meget vanskelig at observere og lader sig neppe hverken ved Dissection eller ved andre Methoder fremstille $\mathrm{i}$ sin Helhed. Jeg har imidlertid strkkevis kunnet noiere undersoge samme og fundet, at den, som hos Branchipodiderne, dannes af 2 vidt adskilte starke Nervestammer, der passerer bagtil langs Bugsiden af Truncus og i hvert Segment ev forbundne med \& tynde Trærcommissurer. Nervestammerne viser paa dette Sted en ganske svag ganghos Opsrulmning og udsender udad, i adskillig Afstand fra hinanden, 2 stærke Nerver, hvoraf rlen ene trader ind $\mathrm{i}$ den respective Fod, medens den anden synes at udbrede sig i Kroppens Sidemuskulatur.

Forplantningsapparat. - Da alle hidtil observerede Exemplarer af leme Phyllopode har vist sig at være af Hunkjon, har vi her km at omtale Hunorganerne eller Orarieme. Disse (se Tab. XV. Fig. 1) har Formen af 2 noget shrueformigt dreiede Ror, der strækker sig igjennem Storsteparten af Truncns, til hrer sirle af Tarmen, og ender bagtil med en smalere spidst udlobende Del. Bagenfor Midten udgaar fra hvert Orarium nedarl en kort Egleder, der ndmunder i Basis af den tilsvarende Fod af 11 te Par. Fra Overfladen af ovarialrorene ndgaar talrige smaa blindsalformige Udvilninger, sum hos gauske unge Individer (se Tab. XVI, Fig. 15) viser et temmelig miformt Udseende, medens de hos celdre Individer antager eu meget forskjellig Udvikling og delvis grupperer sig paa en drueklaseformig Maade (se Fig. 16. 17). Tisse Udvidninger er Wigfolliklerme. hvori Aggenes forste Dannelse foregaar. Undersoges disse Follikler noiere (se Fig. 18), vil man i deres Indre altid finde, som hos Lepidurus, 4 C'eller combinerede, livorat blot den ylerste bliver til det vinkehige $A g$, medens de 3 ovrige forestiller Næringsceller. Paa de mindste Follikler, der er nogenlunde cylindriske af' Form, er alene de 4 Celle- fig. 10), but are of a similar conical shape. From them originate the nerves for the 1st pair of antenuæ, viz., a very fine nerve for the muscles in the basal part of these antenna, and a much stronger nerve-stem which passes into the club-like terminal part, and sends off numerous fibres to each of the lateral lobes (see Pl. XV, fig. 5). The nerves for the 2nd pair of antenne ( ${ }^{2}$ ) do not issue from the cerebral ganglion itself, but from the strong rommissures ruming backwards from it, which suround the asophagus in order to join the rentral ganglion chain. Two such nerves can be clearly distinguished, of ahout equal thickness, and issuing close together a little in front of the mildle of the commissures which here exhibit a very slight ganglionic swelling. As regards the further course of the nerves in the antennze themselves, it has not been possible for me to obtain any very satisfactory idea.

The remainder of the central nervous system is very difficult to observe, and scarcely allows of being represented in its entirety, either by dissection or by any other method. I have, however, been able to examine parts of it in detail, and have found that. as in the Branchipodida, it is formed of 2 wirlely-separated, strong nerve-stems, passing luackwards along the ventral sicle of the trunk. and connected in each segment with 2 thin transverse commissures. The nerve-stems here exhibit a very slight ganglionic swelling, and send out ontwards. at a considerable distance from one another, 2 strong nerves, one of which enters the corresponding leg. while the other seems to spread over the lateral mnscrlature of the body.

Sexual Organs. - As all the specimens of this Phylloporl hitherto observed have proved to be of the female sex, we have here only to describe the female organs or ovaries. These (see Pl. IV, fig. 1) are in the shape of 2 tubes, twisted somewhat after the manner of a screw, which extend through the greater part of the trunk on each sicle of the intestine, ending behind in a narrower, pointed part. Beyond the middle, a slort orjduct issnes in a downward direction from each ovary, opening one on each side at the base of the 11 th leg. From the surface of the orarial tubes, there issue numerous small creal expansions, which in quite young specimens (see Pl. XVI, fig. 15) present a fairly uniform appearance, while in older animals they assume a very varied development, and are to a certain extent grouped in a botryoidal manner (see figs. 16, 17). These expansions are the egg-follicles, in which the earliest formation of the ova talies place. On a close examination of these follicles (see fig. 18) there will always be found inside them, as in $L e$ piturus, 4 cells combined, of which only the onter one turns into a true ovum, while the other 3 represent alimentary cells. In the smallest follicles, 
kjærner synbare; men meget snart sondres dog det til enhver Kjærne horende Plasma og afgrændser sig red skarpt markerede Linier. Samtidigt begynder den terminale Celle hurtigt at voxe og fylder sig med et opakt kornet Indhold, medens de 3 ovrige Celler forbliver gjennemsigtige og omvendt rednceres i Storrelse, saa at de tilsidst kun er tilstede som ubetydelige Rudimenter verd den indre Side af den egentlige Egcelle. Deme sidste naar tilsidst (se Fig. 17) en temmelig anselig Storrelse og fylder den hele Follikel, som nu springer fiem fira Ovarialroret som en kugleformig, knrt stilket Blære. Er Eggene fardige, losnes de fra Folliklemes Vægge og trader ind i Orariemes Hule. I denne har der imidlertid ansamlet sig et opakt hvidagtigt Indhold (se Tab. XIV, Fig. 6), der pra friske Exemplarer viser sig overordentlig fint kornet, men paa Spiritusexemplarer hurtigt coagulerer til en comnakt gulbrun Masse, der indtager Axen af Ovarialrorernes indre Hule og delvis ogsaa fortsatter sig ind i Eglederen. Dette Indhold synes at være et Secretionsprodukt af Ovarialroremes Vagge, bestemt til at afgive Materialet til den eiendommelige Skal eller Krapsel, der senere omgiver hvert enkelt Aig. I Begyndelsen, efterat være indkomne i Ovariernes indre Hule, el dog Eggene enlm nogne, og antager derfor forskjellige Former ved gjensidigt Tryk eller derved, at de passerer igjennem trangere Steder af Ovarierne (se Tab. XVI, Fig. 16). De synes at opholde sig i Ovarialhulen i langere Tid, og bliver herunder ved peristaltiske Bevægelser af Ovarierne skyvet frem og tilhage, hvorved deres Overtlade kommer i intim Contact med det ovenomtalte Secret. Snart olserveres ogsaa paa dem den forste Antydning til Skallen (se Fig. 19), og denne er ialmindelighed fuldt færdig, skjondt endnu blod og boielig, forend Eggene gjennem Eglederen ndfores af Legemet. De samler sig derefter umiddelbart over Trunens til en compact Masse, der holdes i Situs ved Hjælp af den traadformigt forlængede dorsale Lap af ide til 11te Fodpars Exopoditer (se Tab. XIV, Fig. 1, 2). Egmassen, der ligger noget foran Midten af Skallens dorsale Hule, viser en temmelig uregelmæssig Form, med den ovre Flade stærkt hvælvet, den nedre concav, $o g$ Fanterne nregelmessigt indskaarne. Den bæres her af Dyret i lengere Tid, indtil Egkapslerne har naaet den fornodne Fasthed, og dens Farve forandres hermuder grarlvis fra en meget lys, lnvidagtig til en mork hornbrun Coulenr. De i den indeholdte $\mathrm{Eg}$, der er holdte sammen ved et kilæbrigt Stof, er meget smaa og derfor i Regelen overordentlig talrige. De er hvert omgivet af en hoist eiendommeligt udseende og meget fast Kiapsel af nresten turbinlignende Form (se Tab. XYI, Fig. 20, $21,22)$, med 2 lodret paa hinanden stillede vingeformige Udvidninger. Langs ad den ene af disse Udvidninger lober en tydelig fortykket Ribbe, livor- which are somewhat cylindrical in shape, only the 4 cell-molei are visible; but very som the plasma belonging to each molens is separated and defined by clearly-marked lines. At the same time the terminal cell begins to grow quickly, and to be filled witb contents of an opaque, granular character, while the 3 other cells remain transparent, and are inversely reduced in size, until at last they are only present as indistinct restiges on the inner side of the egg-cell proper. The latter at last (see fig. 17) attains a very considerable size, and fills the whole follicle, which now projects from the ovarial tube like a spherical, short-stalked vesicle. When the ova are ready, they become detached from the walls of the follicles, and enter the carities of the ovaries. Here an opaqne, whitish matter has meanwhile collected (see Pl. XIV, fig. 6), which in fresh specimens appear's to be very finely granular, hut in spirit specimens rapidly coagnlates into a compact yellowish-brown mass occupying the axis of the inner cavities of the ovarial tuhes, and is also to some extent continued into the ovidnct. This substance seems to be a secretive product of the walls of the ovarial tubes, designed to furnish the material for the peculiar shell or capsule which subserquently envelopes each ovum. At first, after having entered the inner cavities of the oraries, the ova are still naked, and therefore assume varioms shapes resulting from reciprocal pressure, or from their passage through narrow parts of the ovaries (see Pl. XVI, fig. 16). They appear to remain for some time in the ovarial cavity, and, by peristaltic morements of the ovaries, are pushed hackwards and forwards, their surfaces thus being brought into close contact with the above-mentioned secretion. The first indication of a shell is soon observable upon them (see fig. 19), and, thongh soft and pliable, it is quite perfect before the orm is evacuated from the body through the ovidnct. The ova then collect immediately ahove the trunk, into a compact mass, which is retained in position by the aid of the filiformly elongated dorsal lappet of the exopodite of the 9 th, 10th and 11 th pairs of legs (see Pl.XIV, figs. 1, 2). The egg.mass, which lies a little in front of the midlle of the dorsal cavity of the shell, is of a rather irregular shape, with the npper surface highly comvex, the lower concave, and the edges irregularly indented. It is carried here by the animal for some time, until the egg-capsules have acquired the necessary firmness, and during that time its colour gradually changes from a very light, whitish hue to a dark horny brown colour. The ova composing it are held together by a glutinous substance, and are very small and therefore generally exceedingly numerons. They are each enveloped in a very firm capsule of most peculiar appearance, and almost turbinate shape (see Pl. XVI, 
fra bnede sideribber udgaar til den modstaaende Trdvidning, livilken sidste ender med en tilskjærpet Kant og viser en fint cellulos Structur (se Fig. 2:3). Ved hrilke mekaniske Midler ilenne eiendommelige Form af Egkapselen, der er noiagtig ligedan hos alle Eg, tilreiebringes, er ikke saa gorlt at sige. Rimeligris spiller hervel den skrueformige Dreining at Ovarialtubeme en rasentlig Rolle. Egmassen bliver med visse J[ellemmm, rimeligvis i Forbindelse med Hudskiftningsakten, udstodt af Skallen, og falder derpa tilbunds, hror den indleires i IIudret. Imidlertid har Ovarierne produceret et nyt Saet Eg, som snart samler sig til en ny Figmasse under den dorsale Del af rikallen. Pa demne Maade kan et og samme Individ i Lobet af nogle Uger prodncere et enormt Antal af Eg. Wisse ndklakkes dog i Regelen alurig samme Aar, som de el lagte, men er alle bestemte til at orervintre; ja der er Grund til at antage, at de $i$ mange Tilfrelde kan henligge i en hrilende Tilstand gjennem meget lange Tirlsrum, tildels fuldstrendig indtorrede, fir de udklækkes.

Udvikling. - Om Udviklingen af denne Phyllopode har den franske Naturforsker Lerebonllet i Aaret $1866^{2}$ ) leveret en meget udforlig, af Afbildninger ledsaget Fremstilling, hrortil senere Forskere altid har henholdt sig, uden at der, saaridt mig bekjendt, er anstillet fornyede Undersogelser over denne side af nærværende Frorms Biologi. Ogwaa Kjonsorganernes Bygning er af samme Forsker meget udforligt omtalt $\mathrm{i}$ samme Afhandling, men hans Fremstilling er her i Here rasentlige Punkter urigtig og misvisende. Da jeg har havt en sjelden gor Anledning til at studere demne Forms Udvikling ug tror i flere væsentlige Punkter at kumne supplere og berigtige den af Lerehonllet girne Fremstilling, skal jeg $\mathrm{i}$ det folgende torsoge noget udforligere at beskrive samme.

Tilviklingen kan passende inddeles i 2 Perioder, den larvale og jostlarvale, begge vel markerede fra hinanden. Den forste Periode er tilendebragt i meget kort Tid, ialmindelighed i Lobet af nogle faa J)age, hyorimod der til den anden Periode ndkræves mindst en hel IIaned.

Larveudviklingen. - Larren kommer til Terten i en yderst ufuldkommen Tilstand, som en saakaldt Nauplins, nden at rise nogensomhelst Lighed med det roxne Dyr. Legemet har i rette 1ste Sta. dium (Tab. XVII, Fig. 1) kum en Længde af 0,25 mm. og bestaar af '2 ved en svag median Indknibning sondrede Atinit at omtrent lige Storrelse. Det forreste Afsnit repræsenterer Hovedet, det bagerste

1) Annales des siciences naturelles, Zoologie, 5me Série, T. I'. figs. 20, 21, 22) with 2 wing-like expansions placed perpendicular to one another. Along one of these expansions runs a distinctly thickener rib, from which curved lateral ribs run to the opposite expansion, this last ending in a sharp erlge, and exhibiting a finely cellular structure (see fig. 23). By what mechanical means this peculiar form of egg-capsule, which is exactly similar in all the ova, is bronght about, it is not easy to sar. Probably the screwlike twist of the ovarial tubes has much to do with it. The egg-mass, at certain intervals, mrobably comected with the process of exmviation, is thrust out of the shell, and thereupon sinks to the bottrm, where it is imberlded in the mud. In the meantime the oraries have produced a new set of ova, which soon collect into a new egg-mass beneath the dorsal part of the shell. In this way, one animal, in the conrse of a few weeks, can produce an enormons number of eggs. These, however, as a rule, are never hatched in the same rear that they are laid, but are all designed to stand a winter; indeed, there is reason to suppose that in many cases they may lie in a state of quiescence for very long periods of time, sometimes completely dried up, before they are hatched.

Development. - The French naturalist Lerelonllet, in the rear $1866^{1}$ ), published a very detailed account of the development of this Phyllopod, accompanied by illustrations; and more recent naturalists have always referred to this, without, as far as I am aware, any fresh investigations on this point in the biology of the present form having been instituted. The structure of the sexual organs is also very fully described in the above treatise, but here his description, in many essential points is incorrect and misleading. As I liave had an unnsually good opportunity of studying the development of this form, and believe that in several important points I can snplement and correct the account given by Lerebonllet, I will here endeavour to describe it somewhat more fully.

The development may be suitably divided into 2 periods, the larval and the post-larval, both wellmarked. The first period is brought to a conclusion in a very short time, generally in a few days, whereas at least a month is required for the second.

Larval Development. - The larra is brought into the world in an exceedingly imperfect condition, as a so-called nauplius, withont exhibiting any resemblance whatever to the adult animal. The body in this 1st stage (I'l. XVII, fig. 1) has a length of only $0.25 \mathrm{~mm}$., and consists of 2 sections of about equal size, defined by a slight median contraction. The front section represents the head, the hind one, the

1) Annales des Sciences naturelles, Zoologie, óme Série, T. V. 
den ovrige Kirop. Hoverlet er temmelig tykt, lige som opsviumet i sit rlorsale Parti, og stmmpt afknttet fortil, nden spor at noget Rostrum. Det forlænger sig bagtil paa Undersiden i en meget roluminos Plade, der hvelver sig nd over Bugsiden af Dyret og encer i en smal, konisk tillobende Fortsats. Denne Plade er den enormt ndriklede Overlæbe (labrum). I det indre af Hovedet lelt fortil bemærkes $\mathrm{i}$ Midten en meget ioinefaldende blodrod Pigmentmasse af noget nregelmæssig Form: det enkle Oie. Af de sammensatte Gine er der derimod intetsomhelst syor at se. Af Lemmer findes knm 3 Par, de saakaldte Nanplins-Lemmer, alle tilhorende det forreste Afsnit af Legemet og repræsenterende de I Par Folere og Mandibularfodderne. Det forreste Par (a $\left.{ }^{1}\right)$ (1ste Par Folpre) er dog saa smaa og rudimentære, at de let kan oversees, og er heller ikke bemærkede af Lereboullet. De har Formen af 2 ubetydelige limudeformige Fremspring til hver Side af den forreste Ende af Hovedet og noget ventralt, hver forsmet med en enlielt delicat Foleborste (se ogsaa Fig. 5a). Det 2det Par Lemmer $\left(a^{2}\right)$, der representerer 2det Par Folere, er derimod af særdeles betrdelig Storrelse, forestillende et Par kraftigt ndviklede, til Siderne ndstrakte Aarer næsten af hele Legemets Lrengde. Enhver af disse Lemmer bestaar af et tylit cylindriskt Skaft og 2 noget nlige udriklede Endegrene. Skaftet har red Basis i Bagkanten en konisk Fortsats, der ender med en kort borsteformig Spids, og red lets Ende findes, ligeledes i Bagkanten, en lignende, med en noget længere Jagudkrummet Borste endende Fortsats. Af Grenene er den ovre eller forreste noget storre end den anden og omtrent af Skaftets halve Længde. Den er noget opsvulmet paa Midten, næsten tentormig, og viser en meget ntydelig Lerddeling, samt bærer 5 leddede, men endnu ucilierede Svommeborster, hvoraf de 3 udgaar fra tilsvarende Afsatser i den bagre eller ydre Kiant, de 2 ovrige fra Spidsen. Den bagre Gren er simpelt cylindrisk og delt i 2 utydeligt sondrede Led, lrorat det yderste har ved Spidsen 3 Borster af et lignende Udseende som de paa den forreste Gren. Det 3die Par Lemmer $\left(M_{p}\right)$, de saakaldte Mandibnlarfodder, hvoraf intet Spor findes hos det voxne Dyr, udgaar omtrent fra Midten af Legemet, paa Grændsen mellem Hoved og Krrop, og er ligesom 2det Par udstrakte til hver Side, skjondt sadvanlig noget mere lagudboiede. De udspringer hver fra en noget fortrkket, knndeformigt fremspringende Basis, som forestiller det endnn undviklede Corpus af Kindbakkerne. Hver Mandibularfod bestaar af 3 utydeligt sondrede Led, hvoraf det 1ste er storst og forsynet i Bagkanten med 2 pigformige Borster. 2det Led bærer en enkelt lignende Borste, og sidste Led i Spidsen 3 saadanne. Den bagenfor liggende Del af Legemet er uden Spor af Lemmer og af aflang oval Form, remainder of the body. The head is rather thick and as it were swolten in its dorsal region, and is libuntly truncated in front, withont any trace of a rostrum. It is prodnced posteriorly on the inferior side to a very voluminons plate, which arches over the ventral side of the animal and ends in a narrow, conical projection. This plate is the enormonsly developed npper lip (labrum). Inside the head, in the middle right in front, a rather irregulary. shaped, very conspicnous mass of blood-red pigment is risible, - the ocellus. On the other hand, there is no trace whatever of the compound eyes. There are only 3 pairs of limbs, the so-ealled namplins limbs, all belonging to the anterior section of the body, and representing the 2 pairs of antennæ, and the mandibular legs. The foremost pair (a ${ }^{1}$ ) (the 1st pair of antennæ) are, however, so small and rndimentary, that they can easily be overlooked, and have not, indeed, been noticed by Lereboullet. They are in the shape of 2 small, modiform protuberances one on each side of the front end of the head, and somewhat ventral, each furnished with a single delicate sensory bristle (see also fig. 5 a). The 2nd pair of limlss $\left(a^{2}\right)$, which represent the 2nd pair of antemne, are, on the other hand, of very considerable size, forming a pair of powerfully developed oars, extended laterally, and almost as long as the borly. Each of these limbs consists of a thick cylindrical scape, and 2 rather nnequally developed, terminal rami. At its base, in the hind margin, the scape has a coniral projection, ending in a short, bristle-like point, and at its end, also in the hind margin, a similar projection ending in a rather longer bristle bending backwards. Of the two rami the nuper or foremost one is rather larger than the other, being abont half the length of the scape. It is somewhat swollen in the middle. almost fusiform, and exhibits a very indistinet articulation; it also carries jointed, but not as yet ciliated natatory bristles, 3 of which issne from corresponding ledges in the hinder or outer margin, the other 2 from the point. The hind ramms is of a simple cylindrical shape, and is divided into 2 indistinctly defined joints, the onter of which has at its point $B$ bristles similar in appearance to those on the front ramus. The 3rd pair of limbs $\left(\mathrm{M}_{3}\right)$, the so-called mandibular legs, of which no trace is to be found in the adult animal, issue from about the middle of the body, at the dividing line between the head and the trunk, and, like the second pair, extend one to each side, though generally bent rather more backwards. They each issue from a somewhat thickened, nodiformly projecting base, which represents the still nndeveloped body of the mandibles. Each mandibnlar leg consists of 3 indistinctly defined joints, of which the 1 st is the largest, and is furnished, on the hind margin, with 
med et lidet Indsnit i Enden (f). Af de ovenfor heskrevne Lemuer, rler alle horer til Hovedet, er let forreste Par ndelnkkende Foleredskaber, medens de 2 orrige Par, og narmlig det 2det, er Srommeapparater, red livis Slag forfra bagtil Legemet stodvis drives frem giennem Vandet. Bevægelserne er $1 \log \mathrm{i}$ dette 1ste Starlium endnu temmelig afbrudte og ubehjalpelige. Forst efterat Larven lar undergaaet sin 1ste Hudskittning, og Srommeborsterne har faaet sin Ciliering, bliver Bevægelserne mere regelmassige og energiske. Angraende den indre Organisation, saa lader sig herom lidet eller intet anfore, da der endnu lim synes at vare indtraadt en vderst nfuldkommen Differentiation af de forskjellige Tær. Hele Legemet ligesaavelsom Lemmerne er fyld med en anorph ensformig kornet IFaterie, der giver Dyret en temmelig opak graalig Farve, uden at nogen indre Organer med Sikkerhed lader sig paavise. Vistuok bemarkes ofte i Axen af Legemet en svag gulagtig Tone, der kunde synes at antyde Tilstederarelsen af Tarmroret; men dette el i ethvert Fald endnu ikke tydeligt afgrændset fra de omliggende Dele.

Tmiddelbart efter den Iste Hudskiftning ser Larven saaledes ud som fremstillet Fig. 2 (fra Rygsiden). Det hagre Afsnit af Legemet har nu forlæuget sig adskilligt og antaget en mere cylindrisk, eller noget konisk Form, og viser i nogen Afstand fra Enden en svag ludsnoring, ligesom antydende et terminalt Segment, svarende til Haledelen hos det udriklede Dyr. Bagtil har dette Segment en liden Indbugtning og gaar til hrer Side af demne and i en kort indadkrummet Fortsats. Hovedets Form er paa det nærmeste nforandret, og ogsaa Lemmerne af en lignende Byming som los 1ste Stadinm, dog med Aen Forskjel, at alle Srommeborster paa 2det Par $n n$ er fint ciliererle, og at de 2 fra Skaftet ndgaaende Fortsatser begge har antaget Formen af strerke, bagndkrummede Borster, hvoraf navulig den inderste er kraftigt ndviklet og tæet cilieret i sit ydre Parti. Ogsaa de 3 laterale Borster paa Mandibularfodderne er nu grovt cilierede, medens de an Endeborster synes at mangle Ciliering. () verlabens terminale Fortsats har forlænget sig adskilligt, san at den rækker noget nd over Legemets bagre Ende. Legemet er endnn fyldt med en liguende amorph kornet Materie som i 1ste Stadinm, men Tarmroret er $\operatorname{dog} n$ tydligere sondret og viser sig betydelig tykkere fortil end bagtil. Larren, der nu har en Lrengle af $0,36 \mathrm{~mm}$, srommer temmelig raskt on i Tandet verl rhytmiske Slag af 2det Par
2 spiniform bristles. The 2nd joint carries one such bristle, and the last joint, at its extremity, 3 . The part of the body lying behind has no trace of limbs, and is of an oblong oval shape, with a small emargination at the extremity (f). The foremost pair of the above-described limbs, all of which belong to the hearl, are exclusively sensory organs, while the other 2 pairs, and the 2 nd in particnlar, are swimming implements, by whose strokes from front to back, the body is driven forward by jerks througl the water. The movements in this 1st stage, however, are still rather intermittent and awkward. Only when the larva has undergone its first exnviation, and the natatory bristles have become ciliated, do its movements become more regular and energetic. Concerning the internal organisation there is little or nothing to be said as only an exceedingly imperfect difterentiation of the various tissnes appear's as yet to have taken place. The whole of the body, as well as the limbs, is tull of an amorphons, uniform, granular matter, which gives the animal a rather opaque, grayish colour, withont allowing any of the internal organs to be made out with certainty. It is true that in the axis of the loody a faint yellow tinge may often be observed, which might seem to indicate the presence of the intestinal tube; but this is at any rate not distinctly marked off from the surrounding parts.

Immediately after the 1st exuviation, the appearance of the larva is as represented in tig. 2 (from the dorsal surface). The hind section of the hody has now lengthened considerably, and has assumed a more cylindrical, or somewhat ronical shape, and at some distance from the end it exhibits a slight constriction, as thongh indicating a terminal segment, answering to the caudal part of the fullydeveloped animal At the tip, this segment has a small sinus, and goes out on each side into a little incurved projection. The shape of the head is as nearly as possible unchanged, and the structure of the limbs is very similar to that in the 1st stage, ret witl the difference that all the natatory bristles on the and pair are now finely ciliated, and that the 2 projections issuing from the scape have both assumed the shape of strong, backward-curving bristles, of which the inner one is more powerfully dereloped and thickly ciliated in its outer part. The 3 lateral bristles on the mandibular legs are also now coarsely ciliated, while the 3 terminal bristles seem to be destitute of cilia. The terminal protuberance of the labrum las lengthened considerably, so that it extends somewhat beyond the hind end of the body. The body is still full of an amorphons, granular matter like that in the first stage, but the intestinal tulue is now more distinctly defined, and appears considerably thicker in front 
Folere og delvis ogsaa Mandibularfodderne, hrorved snart Ryg- snart Bugside vendes opad.

Et noget senere Stadium er firemstillet Fig. 3 fra Bugsiden. Larven har nu naaet en Læugde af $0,47 \mathrm{~mm}$ og har Legemets bagre Afsnit end mere forlænget, skjondt fremdeles uden Spor af Lemmer. De terminale Fortsatser, som aabenbart svarer til Haleklorne hos det voxue Dyr, har strakt sig betydeligt i Lrengde og er skilt ved et dybt Indsnit, $i$ hvis Bund Analaabningen er beliggende. I det indre af Overlaben sees flere meget tydelige celleagtige Legemer, aabenbart af kjertelagtig Natur, ng dens terminale Fortsats er nu fuldkommen saa lang som den proximale Del af Overlæben og skrat nedadrettet. Mandibularfoddernes Rodstykke har sondret sig skarpere fra Legemet og forlænget sig indad mod Mundaabningen, hvorved det nn meget tydeligt viser sig at repræsentere Kindbakkernes Corpus. Selve Lemmerne synes dog ikke at have undergaaet nogen væsentlige Forandringer i sin Structur. Legemet er i dette Stadium betydelig mere gjennemsigtigt end $\mathrm{i}$ de 2 foregaaende Stadier $o g$ næsten vandklart, saa at den med gulfarvet Indhold fyldte Tarmkanal med stor Tydelighed skinner igiemnem de tynde Integumenter.

Fig. 4 fremstiller (fra Rygsilen) et betydelig senere Stadium, som er nærverl at skifte Hnd. Larven har nu en L sængde af $0,65 \mathrm{~mm}$ og har undergaaet flere vasentlige Forandringer. Legemet er idethele temmelig langstrakt, og det bagre Afsnit, uden at regne de terminale Fortsatser, dobbelt saa langt som det forreste, fra hvilket det er sondret ved en meget tydelig Indknibning. I det indre at Hovedet viser sig nn det forste Spor af de sammensatte Cine i Form af 2 smaa, endnu vidt adskilte Pigmentpletter, der ligger til hver Side og noget ovenfor det enkle Oie. Lereboullet har ment, at de sammensatte Oine damnedes ved en Afspaltning fra det enkle Gie, hvad der er aldeles urigtigt. De damnes ganske uafhængigt af det enkle Oie, der baade hrad Storrelse og Form angaar, er fuldkommen uforandret. Af Lemmerne er 1ste Par fuldkommen af samme Udseende som hos de tidligere Stadier, men synes at være rykkede noget længere ned paa Bugsiden. Paa zdet Par har den basale Fortsats klovet sig i Enden i 2 borsteformige, tæet cilierede Spridser, og den bagre Gren har faaet en Svommeborste flere paa Spidsen. Mandibnlarfodderne viser $n u$ alle sine 3 Led meget tydeligt begrændsede, og den fra næstsidste Led ndgaaende Borste har than behind. The larva, which is now $0.36 \mathrm{~mm}$. in length, swims ahout with tolerable rapiclity in the water, with rhythmical strokes of the 2nd pair of antemne, and partly of the mandibular legs, whereby now the dorsal, now the ventral surtace is turned uppermost.

A somewhat later stage is represented in fig. 3, from the ventral surface. The larva has now attained a length of $0.47 \mathrm{~mm}$ and has the posterior. section of the body even more elongated, though still without a trace of limbs. The terminal projections, which evidently answer to the candal claws in the adnlt animal, have increased considerably in length, and are separated from ench other ly a deep emargination, at the bottom of which the anal aperture is situated. Inside the labrum are visible several very distinct cellnlar hodies, evidently of a glandular nature; and its terminal projection is now fully as long as the proximal part of the labrum, and directed oblipuely downwards. The basal part of the mandibular legs has become more sharply dividerl from the body, and is produced inwards towards the oral aperture, thereby showing very clearly that it represents the body of the mandibles. "The limbs themselves, however, do not seem to have undergone any essential change in their structure. The borly in this stage is considerably more transprarent than in the two preceding stages, being almost as clear as water, so that the intestinal canal, with its yellow-coloured contents, shows with great distinctness through the thin integuments.

Fig. 4 represents (from the ventral surface) a very much later stage, when the animal is abont to east its skin. The larva now has a length of $0.65 \mathrm{~mm}$, and has undergone several important changes. The body is on the whole rather elon. gated, and the posterior section, not including the terminal projections, is twice as long as the anterior, from which it is seprarated ly a very distinet contraction. Inside the luear, the earliest traces of the compound eyes now appear in the shape of two small, and as yet widely-separated spots of pigment, lying one on each side, and somewhat above the ocellus. Lerebonllet thonght that the compond eves were formed by a splitting off from the ocellus, a theory which is altogether incorrect. They are formed quite independently of the ocellus, which, both as regards size and shape, is altugether unchanged. The 1st pair of limbs is of exactly the same appearance as in the earlier stages, but they seem to have moved a little farther down on the ventral surface. In the 2nd pair, the basal projection has divided at the end into 2 bristle-like, thickly ciliated points, and the posterior ramus has acruired another natatory bristle at the point. The mandibular legs now show all their 3 joints very 
antaget en pigformig Character, damencle den umiddelbare Fortsættelse af Leddet. Den terminale Fortsats af Overlaben, ligesom de $m$ stærkt forlængede Halefortsatser viser sig rundtom tæt besatte med korte Pigge. Paa let bagre Afsuit af Legemet Jjemærkes de forste Anlæg til Rygskjoldet og til de 6 forreste Par Fodder. Alle disse Dele er dog endum drkkede af Larvehuden, som uden nogensomhelst Afbrydelse strækker sig over dem. Rygskjoldet (den senere Skal) har Formen af 2 smaa, endnu ikke med hinanden dorsalt forbundne afrundede Folde helt fortil, i hvis Indre den forste Antydning til Skalkjertelen lader sig paavise. Fodderne har endnn kun Idseende af en Række af 6 ubetydelige knopformige Fremspring langs Siderne af Kroppen umiddelluart bag Anlægget til Rygskjoldet. De aftager sncessivt i Storrelse bagtil, og de 2 sidste Par er kun meget svagt antydede. I det indre af det serdeles giennemsigtige Legeme sees nu Tarmkanalen med stor Tydelighed. Den har bagtil sondret en se] begrændset, stærkt muskmlos Endetarm, og gaar fortil ud $\mathrm{i}$ Q korte hlindsektormige $\mathbf{l}^{\top}$ d vidninger: : den forste Begyndelse til den senere saa complicerede Lever. De forskjellige Muskler, der tjener til Aarernes og Mandibularfoddernes Berægelse kan nu med stor 'Tydelighed adskilles, og Larven bevæger sig ogsaa i dette Stadium adskilligt mere energiskt end $i$ de tidligere.

I det næste her afbildede Stadinm. (Fig. 5) har Larven en Længde af $0,87 \mathrm{~mm}, o g$ viser en videre Urlvikling af det hagre Afsuit af Legemet, som nu, inclusive de terminale Forsatser, er over 3 Gange saa langt som det forreste. De Dele, der paa foregaaende Stadium, viste sig nmiddelbart indentor Larvehuden, nemlig Rygskjoldet og de 6 Par Fodknuder, treder nn alle frit frem tra Legemets Overflade $o g$ bar tiltaget noget i Storrelse. De sammensatte Oine er ligeledes betydelig storre og er rykkede noget nærmere sammen, skjondt de endnu er skilte i Midten ved et tydeligt Mellemrum. Ethrert af dem er nu omgivet af en klar Bræm, hrori senere de enkelte Synselementer ndvikler sig. I Brgningen af de 3 Par oprindelige Nauplins-Lemmer viser ikke Larven nogen ræsentlige Forskjelligheder fra samme hos det sidst beskrevne Stadium. En Foles af 1ste Par er afbildet meget stærkt forstorret Fig. 5 a ; den riser, som det vil sees, fuldkommen det samme rudimentare Udseende som hos de yngste Larrer.

Fig. 6 fremstiller en Larve $\mathrm{i}$ et senere Stadium, seet fra renstrp side, med den tilsvarende Aare udeladt, for at rise de af denne drekede Dele af Hovedet trdeligere. Larvens Jangde er lidt over $1 \mathrm{~mm}$. De ? Afsnit af Legemet viser sig meget distinctly defined, and the bristle projecting from the last joint but one has acqnirerl a spiniform character, forming the inmediate continuation of the joint. The terminal motuberance of the labrum, as also the now greatly elongated candal projections, appear thickly covered all round with short spines. On the posterior section of the horly, the earliest ludiments of the carapace and of the i; foremost pairs of legs are observable. All these parts, how ever, are still covered by the larval skin, which is stretched over them withont any interruption what ever. The carapace (the future shell) is in the shape of 2 small, romded folls right in front, and not connected dorsally with one another, insicle which the earliest indication of the shell-gland may be made out. The legs have still only the appearance of a $10 w$ of $i$ small, bud-like projections along the sides of the body, immediately behind the mliment of the carapace. They diminish in size snceessively behind, and the last 2 pairs are only very faintly indicated. In the interior of the exceedingly transparent boly, the intestinal canal is now seen with great distinctmess. Posteriorly, a well-defined, very muscular rectnm has been divided ott, and in front, it forms 2 short cæcal expansions, - the earliest commenrement of the subse "fnently so complicated liver. The different muscles employed in the motion of the oars and the mandibular legs, can now Je very clearly distingnisher, and the larva moves much more energetically in this stage than in the earlier ones

In the next stage represented here (tig. 5) the larva has a length of $0.87 \mathrm{~mm}$. and exhibits a further derelopment of the posterior section of the bodr, which now, including the teminal projections, is more than 3 times as long as the anterior section. Those parts which in the preceding stage appeared immediately within the larral skin, viz. the carajace and the $b$ pairs of pedal buds, now all project freely from the surface of the loody, and have somewhat incleased in size. The compound eyes are also considerably larger, and have mored a little nearer together, thongh they are still separated in the middle by a distinct space. They are both surrounded by a clear rim, in which the visnal elements are subsequently developer. In the structure of the 3 pairs of original namplins limbs the larva presents no essential difference from those in the last-described stage. One antenna of the 1st pair is shown, very lighly magnified, in fig. 5 a ; as will he seen, it presents exactly the same rudimentary appearance as in the youngest larva.

Fig. 6 represents a larva in a later stage, seen from the left side, with the left oar omitted in order to show more distinctly those parts of the head which it covers. The lengtl of the larva is a little over $1 \mathrm{~mm}$. The 2 sections of the body appear 
trdeligt sondrede, idet der mellem dem ogsaa dorsalt el en temmelig dyly Indlungtning. Horedet er jarnt hralvet oventil og afrundet furtil, med et stmmpit Frenspring nerlenfor det enkle Oie, forestillende Anlregget til Rostrum. Umiddelbart bag dette Fremspring sees de endnn knudeformige 1ste Par Folere at udgaa. Bag disse igjen r'ager den enormt ulviklede Overlæbe firem, med sin skrat nedadrettede pigtormige Endefortsats. Ved dennes Basis er der indad en liken eilieret tap, der sædvanligvis er boiet ind mod Dundaalmingen ug som svarer til den verticalt stillede Endelamelle hos det voxne I)yr. Til hver side af Mundaalmingen sees de nu vel ndviklede Kindbakker, fra hvis ydre Side Mandilularfodderne ndgaar, og umiddelluart bag dem igjen viser sig Anlægget til de 2 Par Kjærer. Rygskjoldet har nu udriklet sig til en kappeformig Huddnplicatur, bestaaende af 2 symetriske Halvdele skilte bagtil i Nidten ved en dyl, Indbugtning. Det har nu tydeligt sondret sig ogsaa fortil; men de 2 Halvdele gaar ganske nmærkeligt over i hinanden dorsalt, nden at der endnu er nogen tydelig Sondring af 2 Valvler. De sig udviklende Forder, der nu fuldstændig dækkes orentil af Rygskjoldet, har forlænget sig til noget polseformige Fortsatser, der er rettede skraat luagtil og ligger tert sammen. Den bagerste Del af Kropren er ganske svagt omboiet mod Bugsiden og begynder at sondre sig som en tydelig Haledel. De terminale Fortsatser viser sig nu klarlig at være identiske med de senere bevægeligt til Enden af Haledelen indleddede Halekilor. I nogen Afstand fra dem paa Dorsalsiden har allerede Haleborsterne ndviklet sig; derimod er der endnu ikke noget spor at de for det roxne Dyr characteristiske tandede Haleplader. Af' de F'orandringer, der er foregaaet med den indre Organisation kan nærnes, at de i tidligere Stadier simple blindsokformige Udvidninger at Tarmens forreste Jel har hrer sondret sig i en dorsal og en ventral Lap, og at Hjertet har dannet sig $\mathrm{i}$ den forreste Del af Truners.

Sidste Larvestadim er fremstillet Fig. 7 , fira Rygsiden. Legemet har mu en Lengrde af $1,14 \mathrm{~mm}$. og ligner idethele samme hos de ¿ foregaaende Stadier, dog med den Forskjel, at Huredets Pandedel er noget mere fremspringende, og at Rygkjolutet er betydelig storre. Dette sidste dakker mu som en lored Kappe Storsteparten af Truncus tilligemed de til samme horende Lemmer oventil og har lagtil et dybt Indsnit. Fodderne, hvis Antal fremdeles kun er 6 Par, er endmu fuldstrendig ubevægelige, men har nu sondret sig $\mathrm{i}$ sine respertive Hovedafsnit, hvoraf navnlig Epipoditerne er meget tydelige i Dyrets dorsale Stilling. Fra Enderne at Fodderne er allerede korte Borster begyndt at spire 14 - G. 0. Sirs: Fauna Nomegix. rery distinctly defined, as there is, dorsally ton, a rather deep hollow between them. The head is evenly arched above and ronnded in fromt, with a blunt projection below the ocellus, representing the rudiment of the rostrum. Immediately belnind this projection, the still nodiform 1st pair of antennie are seen to issue. Pehind them again, projects the enormously developed labrum, with its spiniform terminal potnberance directed ohlicinely downwards. At its base inside, there is a little ciliated lobe, which is usually bent in towards the oral apertme, and which corresponds to the vertically-placed terminal lamella in the finll-grown animal. On earh side of the oral apertmre are seen the now welldeveloped mandibles, from the outer side of which issue the mandibnlar leg's, and immeriately lehind them again, appear the rudiments of the 2 pairs of maxilla. The carajace has now developed into a hood-sliaped cnticular duplicature, consisting of 2 symmetrical halves, separated behind in the midtle by a deep depression. It has also become well defined in front, but dorsally the two halves rum inite impereeptibly into one another, withont as yet any distinct division into 2 valves. The developing legs, whieh are now completely corered above hy the carapace, have lengthened into somewhat sansageshaper protuberances, directed oblinguely backwards, and lying dose together. The hinder part of the body is very slightly bent down towards the ventral surface, and begins to be marked otf as a distinct caudal part. The terminal projections now show themselves rlearly to be identieal with the caudal claws subsequently movalily artienlated to the end of the candal section. At some distance firm them on the clorsal side, the caudal bristles have alrearly developed, whereas there is as yet no trice of the dentated candal lamelle characteristic of the adult animal. Among the elanges that have occurred in the internal organisation, it may be mentioned that the simple cucal expansions of the front part of the intestine in earlier stages, lave become marked oft into a dorsal and a ventral lobe, and that the lieart has been formed in the anterior part ot the trinks. In fig. 7. thr last larral stage is represented, seen from the rentral surface. The body now has a length of $1,14 \mathrm{~mm}$., and on tise whole resembles that in the 2 preceding stages, though with these differences, viz., that the frontal part of the hearl is rather more prominent, and that the carapare is considerably larger. The latter now cover's like a broad mantle the upper portion of the greater part of the trunk and limbs, and las a deep emargination behind. The legs, which still only nmber o pairs, are as yet quite immorable, but are now divided into their respective principal parts, of whieh notably the epipodites are rery distinct in the animal's donsal pusition. From the extremities of the 
tiem, og, sees Dyret fia Bugsiden, lader ogsaa coxallappene sig tyoleligt adskille. De sammensatte bine er nu l'ykkede nær sammen, og i den periphere Area har allerede Synselementerne begyndt at danne sig. Larren bevager sig om i Vandet paa fuldkommen samme Maade som i tidligere Stadier. Beragelsen tilveiehringes hovedsageligt ved 2det Pau Folere eller Aareme, red lıvis rhytmiske Slag forfia bagtil luegenet drives frem gjennem Vandet paa en eiendomnelig stodvis Maade. Ved hvert Slag af Aareme fores deres basale indadkrummede Fortsats ind mellem Overlæben og Kroplen, saa at de 2 borateformige spidser kommer i Contact med Mundregionem, ing det synes derfor sum om denne Fortsats har en rasentlig Betydning ved Nieringsoptagelsen. Larvetilstauden er nu endt, og med den midklbart folgende Hndskiftning begynder den ¿ten Periorle j Dyrets Udrikling, den postlarvale Tilstand.

Postlarval Udvikling. - Fig. s, y fremstiller 1ste postlarvale Stadium, hrilket folger umiddelbart paa det ovenfor beskrevie sidste Larrestadium, idet kin en enkelt Hudsiftning betegner Grrendsen mellem begge. Og dog viser Dyret nu et totalt forskjelligt Udseende, ligesom dets Maade at hevege sig paa er meget afvigende. Ian has nu ikkesynderlig. Tanskelighed red i det at erkjende en mug Limmadia, skjondt der entnu er tilbage nogle spor fra larvetilstanden. Hrad der vasentlig characteriserer dette Stadium ligeoverfor Larrestadierne, ev den betrdelige Udvikling at Rygskjoldet, som mu har ounformet sig til el tyoleligt treklappet Skal, rer bedækkel Storsteparten at Legemet, ikke blot oventil, men ogsaa til Silerne. Sliallen el dog endnn ikke sa: stor, at Legemet ban fuldstrendig inddrages i samme, saaledes som Tilfirlet er med tuldt udviklede Exemplarer, og Hovedet, ligesom ogsa Halen el derfor altid nbedækkede. En anden vasentlig Forandring bestar i Reductionen at Manribulartorlene og den tinldstæn tige Mangel af de ? fra Aaremes skatt nigaaende bagudhoiede Futwatser. Endelig maa anfores som en rasentlig r'lal'ater, at de hos Larven fuldkommen nberagelige Branchialfodder nu er traadt i Tirksomhed, ndtorende sine rlytmiske svingente Beragelser. Trangdrn af Legenet, malt fra Panden til Enden af Haleklorme er $1,14 \mathrm{~mm}$, eller noiagtig den samme sum hos Lanven i sidste Stadium. Men medens s'kal. len los dette sidste Stadium kun rar $0,40 \mathrm{~mm}$. lang og nepue mere end lialvt sar hoi, har llen nu en Licengde at $0,60 \mathrm{~mm}$. ag en Hoide af $0,60 \mathrm{~mm}$, Jen er gankle lial og gjennemsigtig, uden spor at de hus vaxne Exemplarer forekummende concentriske Liniel. ligesum formen el unget afrigende. Seet fra Silen (se Fig. (1) viser den en uregelmassig at- legs, short bristles have alrealy begun to shout forth, and when the animal is seen from the rentral surface, the coxal lobes may also be distinguished clearly. The compound eyes have now moved close together, and in the peripheral area the visual elements have already begun to form. The larva moves about in the water in exactly the same man. ner as in the earlier stages. The movement is brought about chiefly by the and pair of antennæ or the oars, by whose rhythmical strokes from front to back the body is projelled throngh the water in a peruliar, jerky manner. At each struke of the oars, their basal, incmrved projection is carried in between the labiam and the boly, so that the 2 bristle-like points are bromght into contact with the oral region. It therefore seens as though this projection was of essential importance in the admission of food. The larval condition is now terminated, and with the immediately sncceeding exnviation hegins the 2 nd perjod in the animal's development, the post-larral condition.

Post-larval Development - Figs. 8 and 'y represent the first jost-larval stage, which follows jmmediately after the above-described last larval stage, only a single exuriation marking the homndary between the two. And yet the animal now presents a totally different appearance, its manner of moving being also very different. There is very little diffculty now in recognising in it a young Limnadia, althongh there are still some traces left of its larval condition. What principally characterises this stage as compared with the larval stages is the consilerable development of the carapace which is now transfirmed into a distinctly bi-ralved shell, covering the greater part of the boly, not only above, but also at the sides. The shell, howerer', is not yet so large as to allow of the body being completely withdrawn into it, as is the case with fully developed animals; the head therefore, and the tail are always moovered. Another essential change coulsists in the reduction of the mandibular legs and the total absence of the 2 backmard-rured projections from the scape of the oars. Lastly, it must be mentioned as an essential character that the "[uite immorahle branchial legs in the larva have now begun to art by jerforming their rhythmical, swinging movements. The length of the hody, measuled from the frontal part to the end of the caulal claws is $1.14 \mathrm{~mm}$., or exactly the same as that of the larva in the last stage. But while the shell in that stage was only $0.10 \mathrm{~mm}$. long, and searcely more thas half as ligh, it now las a length of 0.701111. and a height of $0.60 \mathrm{~mm}$. It is qnite clear and transprarent, without a trace of the concentric lines occurring in fullgrown animils, and the shape is somewhat diffelent. Seen from the sille (see fig. 9), it shows an inregular, romnded shape, with the upper margin where the 
rumlet Form, med den ovre Liant, hror Valvlerne stoder sammen, næsten ret og endende sanvel fortil som bagtil med et tydeligt fremspringende Hiorne. Orenfra seet (se Fig. 8) viser den sig temmelig buget, idet Breden næsten er lig Hoiden. Til hrer Side sees Skalkjertelen med den mmildelbart foran samme liggende Muskelarea med stor Tydelighed, og paa Grund af Skallens store Gjennemsigtiglued træeder ogsaa den af samme bedakkede Del af Legemet klart og tydeligt frem. Man lian nu paa Legemet adslille alle de Afsnit, som ovenfor er beskrevèt los det roxne Dyr. Dog er Nakkesegmentet endnu temmelig kort, ng Trumcus kun lidet lrengere end det forreste Afsnit af Legemet. Hovedet har en fra samme los det voxne Dyr temmelig afrigende Form. Dets orre Flade er noget uregrelmassigt Ivalvet og endum nden Spor af det characteristiske stilkede Fastlieftningsorgan, som forst senere dannes ved en gradvis Afsmoring af en Del af Hovedets Dorsalparti. Pandedelen er endnn kun lidet fremspringende, og mellem den og det stmmpt tilrundede Rostrum er der neppe engang den svageste Indbugtning at se. Af Hovedets Vedhang er 1ste Par Folere lidt mele forlangede end hos Larverne, men endnn forlooldsvis smaa og nden laterale Lappe. 2det Par Folere, eller Aareme, har, som ovenfor anfort, tabt baade den bagndboiede Borste ved Enden af Skaftet og den tredelte basale Fortsats. Forovrigt stemmer de, saavel hrad Skaftets som Grenemes Brgning angaar, temmelig nær overens med samme hos Larreme, alene med den Forskjel, at der i Yilerkanten af den ove Gren lar ndviklet sig en kort Pig, hroraf intet Spor rar at se los hine. Overlæben er mu betydelig redneeret i Storrelse og har antaget det for det roxne Drr charaeteristiske Udseende, idet den lange, dolkformige Endedel en srundet ind til en forholdsvis liden tentakelformig Fortsats. Paa Kindbakkerne er der endnu igjen et Pndiment af Mandibnlarfodderne $i$ Form af et til deres Tdersicle fæstet mbetrdeligt lioniskt Appendix uden Spor af Ledrleling eller Borstebesatning. Bag Kindbakkene sees de 2 Par Kjærer, som un, ligesom Kindbakkerne, er i fuld Virksomhed med at bearbeide den optagne Næring. De los Larren anlagte 6 Par Branchialfodder er $n$ functionsmassigt udriklede, ndforende sine characteristiske svingende Bevægelser for Respirationens og Næringsoptagelsens Formaal, og bag dem er der endun Anlreg til 3 eller 4 Par nye Fodder. Haledelen er endmu kun svagt omboiet og Haleklome nfuldstrudigt somdrede fra Haleenden. De har hrer not Basis en enkelt kort Sidetand, og nmiddelbart ovenfor dem ulgaar fra Haleus Dorsalside 2 meget smaa jernsides stillede Fremspring, som forestiller det forste Anlæg til de tanderle Haleplader. Orenfor Haleborsteme har der endridere ndviklet sig et enkelt l'ar af de hos det roxne Dyr her forekommende valves meet, almost straight, and ending both in front and behind in a distinctly projecting eorner. Seen from above (see fig. 8), it appears rather bulging, its breadth being almost erpual to its height. On each side is seen the shell-gland rery distinctly, with the menseular area lving immediately in front of it; and on account of the great transparency of the shell, that part of the body which it covers is seen very elearly and distinctly. All the sections of the loody described above in the adult animal, can now be distinguished. The cervical segment, however, is still rather short, and the trunk only a little longer than the foremost section of the body. The head has a rather different shape to that in the adult animal. Its upper surface is somewhat irregularly arched, and still withont a trace of the characteristic stalked organ of attach ment. which is formed, but not mutil later, by a gradual constriction of a part of the dorsal region of the liead. The frontal region still projerts only slightly, and between it and the bluntly romded rostrum. there is scarcely even the slightest liollow to be seen. Among the appendages of the head, the first pair of antennæ is a little more elongated than in the larva, lout still comparatively small and withont lateral lohes. The 2nd pair of antemne, or the oars, liare, as stated above, lost both the backward-curved bristle at the end of the srape and the bifid hasal projection. In other respects they agree very closely, as regards the structure of hoth the scape and the rami, witl those limbs in the larva, with the one differenee that in the onter margin of the upper ramus a slort spike has dere loped, of which there was no trace in the larva. The labrum is now considerably reduced in size and has assumed the appearance characteristie of the adult animal, the long, ensifor'm terminal part having shrmk into a comparatively small, tentacular mojertion. There is still a rudinent of the mandibular legs left on the manclibles in the form of an indistinctly conjeal appendage, - without a trace of artienlation or bristles, - attached to their onter side. Behint the mantibles are seen the 2 pairs of maxille. which nuw, like the mandibles, are in full activity, manipulating the food admitted The 6 pairs of branchial legs commenced in the larval stage are now able to perform their function, executing their characteristic swinging movements for the purpose of respiration and the admission of food: and there are the rutiments of $301+$ pairs of new legs. The canclal part is still only slightly bent down, and the candal claws imperfectly marked off' from the end of the tail. They each have near the base a single, short, lateral tooth, and immediately above them, there issue from the dorsal side of the tail 2 very mall juxtaposed projections, representing the earliest rudiment of the rlentater 
stærlie. bagudrettede dorsale Tome. De sammensatte Uine har tiltaget $\mathrm{i}$ Storrelse, og deres Srmselementer er nu noksaa tridelige. Umiddelbart nedenfor dem linger dpt enkle (Jie, som har bibeholilt sit Trkende temmelig uforandret. At de 2 Lapjue. hrori hos sidste Lalvestadium enhver af de blindsakformige Uitrichinger af Tarmen var delt, viser den dorsale allevede en Antrdning til en vderligere Klovning. Ungen srommer om i Tandet paa en fra samme los Larreme meget forskjellig Maade, irlet Berægelsen $m$ ikke laengere er stodvis, men mere hav ('haracteren af et ganske jevnt Lob, bevirket vel hastigt paa hinanden folgende Slag af Aaremes rolue Parti. Dyret venter hemuder suart Ryg- snart Bugside opad og giol otte kredsformige Tolter i Tandet.

Paa Tab. IIV er afbildet fra venste Nide 2 mirldellart tolgende Stadier (Fig. $40 \mathrm{~g}$ ), hrouf ril sees, at Skallen hmrtigt roxer i Storrelse, saa at den tilsidst er tilstrakkelig rummelig til at Legemet fuldstandigt lian trakkes ind i samme. Skallens Form er imidlertid temmelig uforandret, skjondt masske noget mere oral end i 1ste Starlium, og der pr fiemdeles ingen roncentriske Linier at se paa Valvleme. Hovedet er nü ved ell trilelig ilorsal Indhugtning sondret fra Nakkesegmentet, og den umiddelhart foran Indbugtningen liggente Tel at dets dorsale Flade begrnder at have sig i Veiret tor at damme det for let voxne Dyr saa oharacteristiske Fastheftningsorgan, hvilket dog endnu læuge ndgar fra Hoverlet med en forholdsvis bred Basis. Pandedelen hegynder lidt efter lidt at antage den for det voxne Dyx characteristiske koniske Form, og under den sees allerede en temmelig dyb lndlughtning, hrouved den sondres fra det nu triangulart fremspringende Rostrum. 1ste Par Folere be. grmder at forlange sig og antage en smalt kollelamet Form. men el endnn hos det sidste af de her omhandlede 2 Stadier (Fig. 5) simple, uden latemle Lappe. Aarenne, hvis basale Del mu altid el fortilstralit, forandrer sig ligeledes gradris, antagende mere og mere den for det vowne Dyr chararteristiske Brgning, idet Grenene forlanger sig ng afinoles $i$ et storle dutal Lerl. Antallet at de paa dem frastede Srommeborstel og Pigge er dng molnu meget ringe sammenlignet med samme hos det voxne Dyr. Kindbakkerne har tabt len sidste Rest af Mandibularfodderne og er nu, saavel hrad Form som Berrbning angaar, fullkommen overensstrmmente med samme hos fuldt udriklerle Individer. Pranchialtodler'mes 'Tal tiltager' gradris, idet der' successivt bagtil danner sig nve Anlag, efterat de formliggende el bleven functionsmassigt ndviklede. Depes Tal er par det Fig. 4 at'lildede Stadim ?, candal laminx. Above the caudal setre moreover, there have developed a single pair of the strong, backward-pointing, dorsal spines occurring here in the full-grown animal. The compound eyes have increased in size, and their visnal elements ale now fairly distinct. Immediately below them lies the ocellns, which has maintained its appearance almost muchanged. Of the 2 lobes into which each of the "æecal expansions of the intestine was diviled in the last lavval stage, the dorsal one already shows signs of further clearage. The young animal swims abont in the water in a manner very difterent tu that of the larva, the motion heing no longer jerky, but having more the charucter of an even dart, brought abont by the rapidly succeenling strokes of the distal part of the oars, during which the animal turns now its dorsal. now its rentral sicle uppermost, and often makes circular tums in the water.

On Pl. XTV, 2 immediately following stages (figs. $t$ and 5) are illustrated from the left side. It will be seen from these that the shell is rapilly inmeasing in size, until at last it is sufticientlr (apacious to allow of the body being completely withdrawn into it. The form of the shell, howerer, is almost mnchanged, though perhaps somewhat more wal than in the first stage, and there are still $n 0$ concentric lines to be seen on the valves. The hear is now divirled from the cerrical segment by a distinct dorsal depression. and that part of its lorsal surface immediately in tirnt of the depression, begins to be raised 11$]$ in orler to form the organ of attacliment so characteristic of the adult animal, which still tor some time issues from the head with a comparatively broarl base. The frontal region begins little by little to assume the conical form characteristic of the full-grown animal, and beneath it may be already seen a rather deep depression, by which it is livided finom the now triangularly projecting rostrum. The 1st pair of antenna begin to lengtien and assume a narrow clarate shape, lont are still, in the latter of the 2 stages now in question (fig. 5), simple and withont lateral lobes. 'The oars, whose basal part is now always extended forwards, are also changing gradnally, and assuming more and more the structure characteristic of the adult animal, the rami being elongated and divided into a greater number of joints. The nmmber of natatory bristles and spines attached to them is still vers small compared with that in the arlult animal. The mandibles have lost the last remmants of mandibular legs, and are now, both as to form and equipment, exactly like those of the fully-developed animal. The number of branchial legs increases gradually, new ruliments heing successively formed behind, as soon as those in front are developed sufficiently to perform their 
paa det Fig. 5 fremstillede 14 Par ialt. Halerlelen sondrer sig tydeligere fra Truncus og bliver mere omboiet. Haleklorne el m herægeligt articulerede par Spirlsen, og Halejladerne hegynder at springe strekere frem. I leres Bagkant viser sig nogle faa tandformige Fremspring, ligesom de ovenfor Haleborsterne ulgaraende dorsale Torne begynder at tiltage i Antal. Hrad den incle Organisation angaar, skal her blot henledes Opmærksomheden paa den ganske gradvise Udvikling af det i Hovedet liggende leveragtige (1rgan, der allerecle $\mathrm{i}$ det sidste af de * lıer omllandlede Stadier (Fig. 5) har opmaaet en temmelig compliceret Bygning. Langrlen af skallen hos risse 2 Stadier er henboldsvis $1,10 \mathrm{~mm}$ og 2,30 mm. Endnn fin'egaar der en lignende gradvis Udvikling af alle Dele af Legemet indtil Skallen har naaet en Læungle af $6-i \mathrm{~mm}$. Da incltreder den 1ste Hudskiftning inden den postlarvale Tilstand, ug meget kort Tirl efter denne er allerede Individet kjonsmorlent, skjont det muluu neppe har opmaret syderlig mere end Halvparten af dets definitive Storrelse.

Fig. of paa samme Planche fremstiller et Individ nogen 'Tid efterat deme Hulskiftuing er foregaaet Som man ser, har Valvleme nu faret sin torste Vaxtstribe, der lober nogenlunde parallel merl og i forholdsvis kort Atstand tra Valvlemes trie Rand. Thannelsen af demne Vaxtstribe er ikke ranskelig at forstaa. Verl Hudskiftningen bliver nemlig kn den incle Nembran af Skallen atkastet, medens den ydre ehitinose Lamelle bliver siddende igien og suppleres nu med en nydannet peripher Del. Denne 1ste Væxtstribe er altsaa intet andet end Kanterne af de primere Valvler, der skarpt afgræudser sig fra den efter Hudskittningen optradenile nydannede bel af Valv\}erne. Skallen, der mu har en Lengle af $8 \mathrm{~mm}$. og en Hoide af it $\mathrm{mm}$., har den dorsale Kant jernt hneformig boiet, dog langtfra saa stærkt som hos fuldt ndroxerde Individer, og det forreste Hjome er, i Inodsretning til hvad 'Tilfreldet el' hos lisse, fuldkommen ligesaa stærlit fremtrædende som let bagre. Det i Skallen indeshntedle Dyr er i alle Henseender normalt udviklet, alene med den Forskjel, at Branchialfoddernes Antal er noget ringere end hos fuldvoxne Exemplarer, nemlig km 20 tydeligt ndviklerle Par, hvoraf allerede 9de til 11te Par har den orre Lap af Exopoditen traadtormigt forlænget. Til siderne af Tarmen sees nu tydeligt Orarieme med sine talrige Egfollikler, og i deres inche har allerede atsat sig det opakt hride Secret, (Wer skal tjene til Dammelsen at Egkapslerne. Efter nogen 'Tids Forlob har Individet faaet sin characteristiske Egmasse under den dorsale Del af Skallen. Demne bres i Regelen af Dyret til neste Hudskiftning, da den sammen med den afkastede Hurl bliver ndstoilt at skallen bagtil. Efter Hnd- functions. In the stage shown in tig. 4, their nomber is a pairs, in that in fig. 5 , there are in all 14 pairs. The caudal part is more distinutly divided from the trunk, and lreeomes more hent lownwards. The cantal elaws are now movably articnlaterl at the point, and the cantal lamellw begin to prujert more. On their hind margin a fow dentionlar prominences appear, while the dorsal spines issuing from above the caulal setre, begin to augment in number. With regarl to the internal organisation, attention is here only drawn to the rery gradual development of the hepatic organ in the head, which, in the latter of the 2 stages here muder lisenssion (fig. 5), has already attained a tolerably complicated struture. The length of the shell in these 2 stages is respectively $1.10 \mathrm{~mm}$. and 2.30 mn. A gralual development of this kind still groes on of all the parts of the boyly, until the shell las attained a length of $1 ;$ or $7 \mathrm{~mm}$. Then ocenrs the 1 st exuriation in the post-larval condition, and very shortly after this, the animal is sexnally matme, althongh it has searcely attained more than half its eventual size.

Fig. $i$ on the same plate. represents an animal some time after this exuriation has taken place. It will he seen that the ralves have now acyuired their tirst line of growth, which rmus almost parallel with, and at a comparatively short distance from the free edge of the valves. The formation ut this line of growth is not diftienlt to mnderstand, for in the exnviation, only the inner membrane of the shell is cast. while the onter whitinons lamella remains, and receives the aldition of a newly-formen peripheral part. This list line of growth is thus nothing more than the edges of the primary valves. which are sharply defined against the newly-tomed portion of the ralves appearing after the exuriation. The shell, which now has a length of $s \mathrm{~mm}$. and a height of $(\mathrm{i} \mathrm{mm}$., has its dursal edge evenly curved, though not nearly so much as in fully developed speeimens; and the foremost corner, mlike that in adult animals, is finlly as prominent as the hind one. The animal enclosed in the shell is in every respeet normally developed, with the one exeejtion that the branchial legs are rather fewer in number than in adult speeimens, there being only 20 distinctly developed pairs, the 9th, 10th and 1lth of which already have the tiliform elongation of the exopodite. The ovaries with their numerons eggfollicles are now distinctly visible at the siles of the intestine, and the oparue white secretion to be employed in the formation of the egg-caponles has already been deposited inside them. After some time has elapserl, the animal has its characteristic mass of eggs mnder the torsal part of the shell. This is generally- carried by the animal until the next exnviation, when it is cast, together with the 
skiftningen er. Valvlerne forstnede med nok en Væxtstribe ndenom den 1ste, en ny Egmasse dannes og saaledes fremdeles. Antallet af paa hinanden tolgende Hudskiftninger er derfor, iberegnet den, der er gaaet nmiddellart forud for 1ste postlarvale Stadium. noiagtig det samme som Antallet af Væxtstriber paa hver Talsel, og omtrent ligemange (tange har i Regelen Individet afsat en Egmasse. Efterhvert som Skallen paa demne Maade ved nydannede periphere Lag tiltager i Storrelse, forandres lidt efter lidt dens Form, idet Rygkanten blirer mere og mere het $\mathrm{i}$ sin forreste llel. Samtidigt bliver de primære Valvler ligesom skudt fortil og indtager tilsidst en forholdsris liden Del af Skallen red dennes overste forreste Hjorne, hvilket sidste i samme Forhold bliver utydeligere og mere afstumpet (se Fig. 1). Hos meget gamle Individer antager Skallen tilsidst, seet fra Silen, en næsten triangulær Form, merl den primære Area skndt helt fortil og næsten umboformigt fremragende, saaledes som antrdet paa den af Prof. Iillieborg girne Figur (Skallen i naturlig Storrelse).

\section{Forehomst ow Leveris.}

Allerede Grube har opgivet, at der i BerlinerMuseet findes opberaret Exemplarer af deme Form, indsamlede af $\mathrm{H}$. Rathke i Norge. Men da dette Fnnd ikke merl et eneste Ord er omtalt i den sidstnævnte Forskers bekjendte Værk: "Beiträge zur Famna Norwegens», og jeg sely under mine mangeaarige Undersogelser af vor Ferskrandsfama aldrig havde paatruffet den, fandt jeg Paalideligheden af denne Opgift af Grulue meget tvivlsom og ndtalte mig ogsaa derhen $i$ en i Vid. Selsk. Forhandlinger merdelt forelobig Heddelelse om Norges Phyllopoder. Forst i Aaret 1885 lykkedes det mig med fuld Siklierhed at faa constateret deme eiendommelige PhylInpodes Forekomst her i Landet. Under en Reise, jeg dette Aar foretog langs Sydkysten af Landet, tog jeg d. 22rle Iuli Station paa en ikke meget stor "gg temmelig flad 0, "Mærdo», ndenfor Arendal, og fandt her allerede den forste Dag efter min Ankomst store Mrngder af Limnadia-Larver i et grundt med 1træsbund forsynet Tjern, "Storekjær» kaldet, beliggende omtrent midt paa Gen. Paa denne Tid rar kun meget faa Exemplarer naaet ud over Larvetilstanden, men i lolset af de folgende Dage optraadte postlarvale Stadier i stor Mrngde, og ved Sintten at Maaneden rar ingen Larve længere at finde. Flere Exemplarer var da allerede rgbærende og havde Valvleme forstnede med de forste Taxtstriber. Ted min Afreise, d. 10de Angust, var Skallen hos de storste Individer omtrent $10 \mathrm{~mm}$. lang og harde 5 Par Tiextstriber. For om muligt at finde fuldroxue Individer, besogte jeg igien Gen skin, out of the shell behind. After the exuriation the valves acquire another line of growth outside the first, a new mass of eggs is formerl, and so on. The number of successive exnviations. inchuding that which immediately precederl the 1st post-larral stage, is therefore exactly the same as the number of lines of growth on each valve, and the animal has, as a rnle, deposited a mass of eggs about the same number of times. While the shell in this mamer increases in size by the addition of new peripheral layers, it gradnally changes its shape, the dorsal edge becoming more and more curred in its front part. At the same time the original valves are as it were pressed forward, and at last occupy a comparatively small part of the shell at its npper front angle, which also, in the same proportion, becomes more indistinct and blunter (see fig. 1). In very old specimens the shell, seen from the side, at last assumes an almost triangular shape, with the original area pushed right to the front, and pror jecting almost mmbonately, as indirated in the figure given by Prof. Lilljeborg (the shell in its natural size)

\section{occurence and Hahits.}

Grnbe has already stated that in the Berlin Insenm there are preserved specimens of this form, collected by A. Rathke in Norway. But as this discovery is not so much as named in the latter naturalist's well-known work "Beiträge zur Fauna Norwegens", and I myself, during my many years' investigations of our (Norwegian) fresh-water fama, had never met with the form, I considered the trustworthiness of Grube's statement to be very donbtful, and expressed myself to that effect in a preliminary aecount of the Phyllopoda of Norway in the Viden. Selsk. Forlandlinger (Proceedings of the Sicientific Society). Not until the rear 1885 did I sneceed in substantiating with certainty the oceurrence of this peculiar Phyllopod in this comtry (Norway). During a journey I made that year along the sonth coast, I stopped, on the 22nd Jnly, at a rather that, and not very large island off Arendal, ralled "Mærdo», and there found, on the very day after my arrival, large numbers of Limnadia larræ in a shallow lake called «Storekjær», sitnated in about the middle of the island, and with a grassy bottom. At that time only a rery few specimens were advanced berond the larral condition, hut in the course of the few following days, post-larval stages made their appearance in great numbers, and by the end of the month there was not a larva to be found. Several specimens were then already carrying eggs, and had their valves furnished with the first lines of growth. At the time of my departure, the 10th Augnst, the shells on the 
i September samme Aar ug opholdt mig her tra den !ne til den 1ode. Limnadierne var m meget sjeldne, men adskilligt storre end de tilligere fundne, skjondt ingen oversteg en Langde af $12 \mathrm{~mm}$. Foruden i det omtalte Tjern fandt jeg den ogsaa paa nogle andre Steder af Den, tildels i yderlig smaa Vandansamlinger, dog her af mindre Storrelse. Derimod fandtes den ikke paa en eneste af de mange omliggende Oer. Ogsaa det folgende Aar gjenfandt jeg lenne Form i Begrndelsen af August paa de samme Steder, men ingen storre end de tilligere indsamlede. Sommeren 18,8 fandt Prof. Collett denne Phyllopode paa en ganske anden Lokalitet, nemlig i en liden Vandkulp i Narheden af Hamar. For at mondersoge denne nye Lokalitet noiere, reiste jeg derop den folgende Sommer i Angust, og jeg havde ikke synderlig Vanskelighed ved, efter Prof. Colletts nærmere Angivelser, at finde den omlandlede $\mathrm{K} n \mathrm{l}$ ?. Jen var imidlertid nu fuldstændig udtorret paa Grund af langere Tids forulgaaende tort Veir, saa jeg alene kunde forsyne mig med noget af det indtorrede Iudder for senere kunstige Udklækningsforsog. To (xange senere har jeg besogt den samme Lokalitet, nemlig i Begrndelsen af September 1894 og i Midten af fuli 1 s!s. Beg.e Gange fandtes tilstrækkeligt Vand i Kulpen og store Mæugder at forskjellige Entomostraceer, men af Limnadier var der intetsomhelst spor at opdage, hverken Larrer ellel roxne, saa det næsten ser ud til, at den nu her er fuldstrudig uddoet, for kanske efter en lang Aarrække paany at optræde ligesaa pludselig som den ex forsvunden. Heller ikke af det IIndider, rer paa disse 2 Udfugter medtoges fra Kulpen har jeg kunnet udklække en eneste Limnadia, medens mine mange Gange gjentagne Udklækningsforsog med det i 1889 samlede Indder aldrig har slaaet feil. Idethele svnes, ogsaa efter andre Forskeres Beretninger, denne Phyllopodes Optræden at være rderst lunefuld. Et Aar kan den træfles i storste Mængde paa et begrændset Omraade, for saa igjen sporlost at forsvinde, og forst efter lange Aarrækker kan den saa optræde igjen enten paa samme Lokalitet eller paa Steder, hror man tidligere aldrig har fundet den.

Augaaende denne Forms Levevis torovrigt, saa synes oreralt kun et enkelt Kuld Individer at unrikle sig for hver Sommer. Man har ialfald hidtil ingen sikre Data for, at flere Generationer har fingt paa hinanden samme Aar. Individernes Livsperiode synes i Regelen kun at være indskrænket til et Par Maaneder, ofte kanske ikke engang saa længe. IIen i Lobet af denne korte Tid vil ialfald en Del af Individerne naa til Kjonsmodenherl og kunne af- largest specimens were about $10 \mathrm{~mm}$. long, ami had 5 pairs of lines of growth. In order to find, if possible, full-grown specimens, I again visited the island in September of the same year, and stayed there from the 9th to the 15th. The Limnadix were then rery rare, funt considerably larger than those previously found, although nune exceerled a length of $12 \mathrm{~mm}$. I also found it in other places on the island besides the above-mentioned lake, sometimes in exceedingly small arcumulations of water, thongh then of a smaller size. On the wther hand it was not to be found on a single me of the many surrounding islands. In the following year also, I found this form again in the beginning of Angust in the same places, but none larger than those previously taken. In the smmmer of 1888 . Prof. Collett fonnd this Phyllopod in quite annther lorality, namely in a little pool in the neighhourhond of Hamas. In order to examine this new locality more minutely, I went up there the following sum mer in Angust, and, from Prof. Collett's exact desaription, had not much difficulty in finding the prowl in question, It was however completely dried up, owing to the preceding long periond of dry reather, so that all I comld do was to take away with me some of the drienl mud, in order to attempt artificial hatching at a finture time. Twice subse. quently have I revisited the same locality, namely, in the legimning of Septemler, 1894 and in the midule of July, 1895. Both times I found suftiojent water in the pool, and large numbers of varions Entomostrara, but no trace of Limmalia was to be discovered, whether larva adnlt, so that it almost appear's as if it were now rompletely extinct, perhaps to appear again after a number of years as suddenly as it has disappeared. Nor yet lave I succeeded in hatching one single limnatia ont of the mud lrought away from the pool on these two excursions, while my uft-repeater hathling attempts with the mud collected in 1889 have never failed. It seems, on the whole, as also from the aceounts of other naturalists, that the ajpearance of this Phyllopod is extremely capricions. One year it may he met with in large numbers over a limited area, then vanisl ntterly, and only after many year's may appear again, either in the same locality, or in places where it has never been found previously

With regard to the habits of this form in other resperts, it always appears that only a single brond of animals is ileveloped each summer. Wre have not, at any rate up to the present, any certain data $t_{1}$ prove that several generations have sucreeded one another in the same year. 'The living' period of the individual animals seems as a rule to be limited to a conple of months, frequently perhaps even less. But in the rourse of this shont time 
satte sine Eo, hrad ler silsrer Artens fortsatte Existens, om Forholdene et andet Aar skulde vise sig gunstige for en ny (tenerations Lrlvikling. Som liegel srnes det $\log ^{\prime}$ at vare et meget lirlet Procenttill at de ittallige Larrer, som i Begyndelsen ur. klækkes, der virkelig kommer til fuld Udvikling. Tarver og Lnger tinter man mlen Forskjel overalt i de Tantlansamlinger, hrori de trættes, lige saa hrppigt tret inde ved Bredden som ule paa dybere Tand. Anderlerles er det med fuldroxne Exemplarer. l)isce holder i Regelen kun til paa de dybeste Steder at Inammen og lier gierne nær Bunden. IDa 1) rrene i Regelen er meget gjennemsigtige, er det ilke saa golt at faa Gie paa dem tra Stranden af. Inog vil ialmindelighed den opake gulhnme Egmasse forraade tem, navnlig naar Bunden, henover hrilken de berrger sig, bestaar af morkt IIndiler. beragelsen er iklie srnderlig luurtig og har Cliaracteren af et forholdsvis sagte og noget ujevnt Lob, hrorunder i legelen Rrggen vender opad. Holdte i A'fuarier kan man noiere studere deres Berægelser og ovrige Leveris. Der kan ikke rare nogen Trivl om, at Drrets lovedsageligste Berugelsesorganer er Aarerne. l)et er ved lurtigt gjentagne Slag til Siderne af disse lemmers rodre Parti, at Legenet bliver drevet igjennem Vandet, skjondt ogsaa Branchialfoddernes siringninger tor til en ris Grad understotte Beragelsen. Stoder I rivet under sine Berægelser paa tatte Conferremasser, formaar det med stor Behrendighed at arheide sig igjennem dem, hrorved den meget berage-lige Bagkiop spiller en rigtig Rolle. Tdethele sees lyret meget ofte at foretage energislie Boininger og Strækninger af denne Del at Legemet, dels for at overvinde Hindringer for dets Passage giennem Tandet, dels for at befri det indre af skallen for fremmede indkomne Partilkler. Weget ofte faar man se, at Iyret med Forenden hefter sig fast til de i Tandet verende Gjenstande, narnlig til Undersiden at Blade eller Conferver i Orertladen at Aqrarierne, "g forbliver i denne Stilling sædvanligris i længere Tid. Fasthettningen synes hoverlsageligst at tilveie. loringes verl de strerke hageformige Pigge langs Forsiden af Aaremes Grene, tildels ogsaa red det eiendummelige fra Horedets Dursalside ulgaaende kolleformige Appendix, som man red noiere Lurlersogelse altid ril tinde er i moiddelbar contact med ilen (yjenstand, hrortil Drret er fastliamret. Drret er herunder ilske i absolut lio, men leer foregaar en svag rhytmisk sringning af hele Legemet trem og tilbage, aabenluart foraarsaget ved de lieftigt bevægede Branchialfodder. Disse Sringninger sker paa finldkumen samme Maade som hos Branchiporliderne, idet de ikike er simultane men sncressive, hrad der giver Incltrykket af en eiendommelig grazios Undulation i Perargelsen. ldethele er det meget sjelden at denne sringende Bevægelse af Branehialfodderne some, at any rate, of the animals attain to sexual maturity, and are able to cleposit their eggs, thereby ensuring the continued existence of the speries, shonld conditions another rear be farorable for the development of a new generation. As a rule, it appears to be a very small perrentage of the inmmerable larve at first hatehed, that really herrme fully dereloped. Larva and young ones are found withont distinction all over the pieces of water in which they are met with, quite as freyuently cluse to the bank as out in deeper water. It is otherwise with fullgrown animals. They generally keep to the deeper prarts of the pond and near the bottom. As the animals are generally very trans arent, it is not rery easy to see them fiom the shore. The oparpe, yellowish brown mass of eggs, however, will generally betray them, esperially if the lrottom, over which they move, consists of dark mur. The motion is not remarkably quick, but las the rharacter of a comparatively slow and somewlyat mneven dart, during which the loack is generally. uppermost. Thien liejt in an arpuarium, its morements and other halits may be more carefully studied. There can be no ilumbt that the animal's most imprortant organs of locomotion are the oars. It is by 'puickly repeated sirle-strokes of the distal part of these limbs that the body is driven through the water, although the swinging of the Jranchial legs may also, to a certain extent, assist the movement. Should the animal, as it moves, come in contact with thick masses of conferre, it manages with great dexterity to work its way throngh them, the very mobile hind part of the body plaring an important part in that proceeding. The animal may often be observed to make energetic bends and extensions of this part of the body, partly to overeome obstacles to its passage through the water, partly to rid the shell of foreign partirles that have entered. The animal may very often be seen to attach itself lys its anterior end to ohjects in the rater, especially to the under surtace of leares or conferre on the surface of the aquarium, and generally remain in this position for some time. The attachment appears principally to be effected by means of the strong, hook-like spines along the front of the rami of the oar's, and partly by the peruliar clarate appendage issuing from the dorsal surface of the head, and which, on close examination, will always be formel in immediate contact with the object to which the animal is elinging. The animal meanwhile is not absolntely at rest, for there is a slight rhythmical swinging to and fro of the whole body, occasioned by the violent agitation of the branchial legs. These pulsations take place in exactly the same manner as in the Branchipodidie, not being simultancous hnt snecessive, thus producing the impressim of a peculiar, 
ganske stopper op. Det sker kum, nar Dyret juldselig formoliges, i hvilket Tiltrelle alle bele af Legemet hurtigt trælikes ind i skallen, hrorpaa leme hemetisk lukker sig ug l)yet synkel tilbunts. Meget suart ahbner imillertil Valverne sig igjen, den forreute Del af Huvedet tilligemed Aarerne strpklier sig forsigtigt frem tortil, og Halen bagtil. hrorpaa igjen Branchialforlderue liegynder sine rhrthmiske svingende Beriegelser.

Drret syues hovedsageligt at næle sig af opsmuld’ede Piantedele, encellede Alger, maaslie ogsaa Infusonier. Disse Dele bliver verl Branchialfoddernes Bevegrelser hrirvet ind i Skallen og passerer herefter bagfia tortil mellem Fudderne imod IImmlen. Kindbakkerne sees at vere i stadig Aktivitet med at bearbeide den af Nunden optagne Naring, som delefter ved Hjalp at de talrige tra Overlaben til Spiseroret gaaende Musklers Virkning bliver svalgt "g iudfort i Tarmens forreste Del. Her undergar Foden en forelobig Oplosningsproces red det intenst gule Secret, der udsondres at Lereren. Fordoielsen symes idethele at gan meget hurtigt for sig, idet 'Tarmens Contenta lnutigt forandrer sin Farve, eftersom de passerer hagtil, fra lyst gult eller orange til et meget morkt brunt eller nasten sort. Med visse Mellemmm blirer Exarementerne red Endetarmens Contractioner ndstodte, ofte i temmelig lange sammenliangende IIasser. I Lighed med hrad Tilfaldet $\mathrm{r}^{\mathrm{h}}$ hos Bramchipoliderne, observeres ofte i Tarmrorets Vagge energiske preristaltiske Berægelser.

Som oventur anfort, har alle hidtil observerede Individer af demne Form vist sig, ifolge sit hele [dseende, at vere Humel, og alle Exemplarer b]iver ogsaa mlen Undtagelse, nas. de har opmaact en visGrad af [dvikling, forsvede merl de claracteristiske Egpaketter under Skallens dorsale Del. Da jeg har observeret denne Form gjennem en Rakke af Aar til forkjellige Tider af Sommeren, og tillige gjentagne Gange har oplrettet den i mine Ayrarier og havt den gaaende her maanedsvis, tror jeg med fuld Sikkerhed at kume constatere, at Hanner overhovedet ikke existerer, og at altsaa narrarende Phyllopodes Forplantning er exchsiv parthenogenetisk. Tette er sameget mere markeligt som For lioldet er et lielt andet med Arteme at den meget nærstaaende Slægt Ealimalia, hvor Forplantuingen ex udpræget bisexuel eller gamogenetisli, idet Hanner og Humer til alle Tider synes at foreliomme ontrent lige Antal. En Tid har jegrigtignok stanet i den Formening, at alle Individer af den hes" om liandlede Phyllopode maske kunde vere hermaplinoditiske eller rettere protanhriske, idet visse Forhold ved Kjonsorganernes Brgning srutes uig at pege i clemne Retning; men liesultateme af de af mig $15-$ G. O. Sars: Fauna vorvegia. grapioms, mululatory motion. It is, on the whole. very seldom that this swinging motion of the luanchial legs entively roases; for it liappens mly. when the animal is suldenly alarmed, in which case all the parts of the body are withdrawn into the shell, which then closes hermetically, and the animal sinks to the hottom. The ralyes, however, very soon reopen, and the fore part of the hear, trgethel with the oars, is rautiously extended in front, and the tail behind, wheremon the branchial legs recommence their rhythmical swinging novements.

The amimal appears to feed mineipally on broken portions of plants, micellnlar alge, and possibly infusoria. These are whirled into the shell hy the movements of the hranchial leg's, and then jass from back to front between the legs towards the nonth. The mandibles are seen to be cunstantly ocrupied in manipulating the food taken in by the month, which then, by the ait of the mumerous mosules muning from the labrum to the (psopluagns, is swallowed and introduced into the anterior part of the intestine. Herp tle fond undergoes a preliminary process of dissolution by the intensely yellow secretion leposited by the "]ivel. l)igestion seems on the whole to take place very rapidly, the contents of the intestine inickly changing colour as they pass backwaxds, from light yellow or orange to a very dark brown or almost black. At certain intervals the exrrements are ejected by the contrartions of the rectum, often in rather long, competed masses. As in the Branclipodidx, energetic peristaltic movements may often be observerl in the walls of the intestinal tube.

As stated alove, all the specimens of this form hitherto observed, have proved, from their whole appearance, to be females; and all slecimens, withont exception, when they have attained to a certain degree of development, are provided with the characteristic chster ot eg's beneath the dorsal part of the shell. Having observed this form at ditferent periods of the summer thomgh a series of years, and having also reared it repeatedly in my anuaria, where it has existed for montlis together, I think I may rleclare with perfect certainty that males in reality do not exist, and that the propagation of this Phyllopod is thus exchavely parthenogenetic. This is so much the more lemarkable, as the circumstince is altogether different in the species of the very nearly-allied genus Fulimadir, where propagation is very markdly bi-sexual or gamogenetic, males and females seeming at all seasons to accur in abont equal numbers. At one time indeed, I was under the impression that all the specimens of the Phyllopor in question might perhaps be hermaphroditic, or rather protanlric, as certain circumstances in the structure of the sexual organs seemed to me to point in that direction; 
senere i den Anledning anstillede noiere Undersogelser har dog ikke forekommet mig overbevisende mok til at jeg tor fastholde demne Opfatming.

Hoist mærkværdig er Eggenes lange Levedygtighed. der endog synes at hamle op med den vel bekjenlte seige Spireerne hos længe opbevarede Plantefro. Som ovenfor anfort, forsynede jeg mig Sommeren 188! med et storre Qrantum af torlet Mudder fra den Aaret iforveien af Prof. Collett undersogte Kulp red Hamar. Af dette Mudder, som jeg har staaende $\mathrm{i}$ en liden Kasse paa mit Laboratorium i den Tilstand, hvori det blev taget, har jeg senere hrer Sommer udtaget simaaportioner og dermed anstillet Tdklækningstorsog i mine Aqvarier. Disse Idklækningsforsog har endnu ikke nogen Gang slaaet feil. Altid har store Mrengder af Larver inden meget kort Tid vist sig i Aqvarierne, og af disse Larver har i Regelen ialfald en Del gjennemgaaet sin hele Udrikling. De paa denne Maade kunstigt opdræettede Individer har jeg hart gaaende i mine Aqvarier mere eller mindre langt ul over Sommeren. De har tilsyneladende trivets udmærliet, hal paa sæilvanlig $V$ is prodnceret sine Egpaketter og har ialmindelighed naaet den samme Maximumsstol'else som de af mig frit indsamlede Exemplarer. Ted de forste Forsog udklækkedes sammen med Limnadierne "gsaa forskjellige andre Entomostraceer; men i de senere Aar er det alene Limadier, der lader sig udklakke af Mudret. Ganske nylig har jeg i et opvarmet Rum giort et nyt Forsog med det samme Wudder, og ogsaa deme Gang, altsaa fulde 6 Aar efterat Mudret blev taget, sel, jeg, at Larver urlklækkes i temmelig betrdeligt Antal, trods den uheldige Aarstid vi skriver idag, da dette nelskives, den 18de Februar). Det er min Agt at tortsrette Experimenterne fremdeles med den tiloversblevne Rest af Huddret, da det forekommer mig at lave adskillig Interesse at taa paa denne Maade sikkert constateret Udstrakningen at Aiggenes Levedrgtighed. En ganslie besynderlig Omstændighert maa jeg her nærne, og det er, nt det endnu ikke lal Iykkets mig at faa de i mine Aqvarier afsatte Eg af denne Form udklakkede, skjondt Residuet er behandlet par samme Maale som red andre Ud. klakningsforsog, idet jeg har ladet det ligge $\mathrm{i}$ ind turet Tilstand Tinteren over. Det synes herefter" nasten som om Eggene af Limnadia trænger', for" at kumne udrikle sig, at ligge torle ikke blot et, men tlere Aar itrek. At jeg paa Mrelo har paatruflet deme Phrllopode i 2 patolgende Aar pa de samme Lokaliteter, kan ikke egentlig siges at modberise en sadan Hypothese, da det jo aldeles ikls er afgiort, at de paatrufue Individer netop 'n nklikkede af te den foregaaende Sommer atsatte $\mathrm{Eg}$.

De eiendommelige vingeformige Udvidninger, but the results of more careful observations made by ne subsequently, have not appeared to me to be sufficiently eonvincing to permit of my maintaining that view.

The great vitality of the eggs is most remarkable, and seems to be on a par with the well-known tenaeions germinating power in long preserved plant seeds. As alleady stated, I provided myselt, in the snmmer of 1889, with a eonsiderable quantity of dried mud from the pool near Hamar, examined by Prof. Collett the year before. (If this mud, which stands in a little box in my laboratory, in the condition in which it was taken, I have since then, every summer, taken out small quantities, and made hatchingexperiments in my aquaria. These experiments have never yet been msuceessful. Always, within a very short period of time, large numbers of larra have made their appeartnce in the aquaria, and, as a rule, a proportion, at any rate, of these larve have gone through their whole development. The speeimens artificially reared in this way have lived in my arpuaria more or less far on towards the end of the summer. They have apparently thriven well, have prodneed their egg-masses, and have generally attained the same maximum size as the naturallyreared specimens eollected by me. At the first attempts, rarious other Entomostraea were hatched with the Limmadix; but in the later years. Limuadix mly have been latehed from the mud. I have quite recently made a fresh trial with the same mud in a heated room; and this time too, fully six rears aftel the mud was taken, I see that the larvæ are being hatched in considerable numbers, in spite of the disadvantageons time of year (it is the 18th February when I write this). It is my intention to coutinue the experiments with the remaindel of the mul, as it appears of considerable interest to me to move with eertainty in this way the extent of the period of the eggs' vitality. One very peenliar eircumstance I must mention here, namely, that I have not yet snceeded in hatehing out any of the eggs deposited in my aquaria by this form, although the residum has been treated in exactly the same way as in other latehing experiments, as I have left it in a dried-up condition throughont the winter. It seems from this as if the eggs of Limnadia, in order to be able to derelope, require to lie $\mathrm{dr}^{2} \mathrm{r}$, not one year only, but several vears in sueession. The fact that on Mrerdo I have met with this Phrllopod in the same localities 2 rears in suceession, eannot really be said to disprove suel a hypothesis, as it is not at all certain that the speeimens found were hatehed from eggs deposited the previons snmmer.

The peculiar wing-like expansions with whieh the 
hrormerl Eggenes Skal er forsynet, har rimeligvis sin Betydning for Eggenes Spredning. Naar Dammene torrer ud, vil nemlig Eggene derved sammen med let opsmuldrede Mudder let kume hvirvles op af Vinden $o g$ fores afsted i storre Afstancle. En saadan Spredning af Eggene red Vindens Hjælp har jeg ogsaa troet at kunne constatere paa Mærdo. Foruden $\mathbf{i}$ «Storekjær", som synes at være det Sted, hrortil denne Fozm oprindelig har været indskrenket, paatraf jeg den paa flere andre Punkter af Den, tildels i en meget betydelig Afstand fra det nærnte Tjern, og undertiden i saa smaa og grunde Regnpytter, at det var umuligt andet end antage, at $\mathrm{Eg}$ rent tilfældigvis med Vinden er overfort hertil fra "Storekjær». Det svnes imidlertid som om der skal ganske særegne Betingelser til, for at denne Phyllopode skal kumne trives. Thi der rar adskillige Smaadamme paa Oen, tildels lige i Nærheden af "Storelijær", hvor" intetsombelst Spor" af den kunde opdages, skjondt disse Damme for andre Entomostraceers Trivsel syntes at være meget gnnstige. Dette synes ugsaa tor en Del at kume torklare denne Phyllopodes mrerkverdig sporadiske For'ekomst.

Udbredning. - Arten blev forst opdaget af Herman i grmole Grofter ved Strassburg; hvor den ogsaa senere er fundet af $r$. Siebold. Brogniart fandt den i Smaatjern ver Fontaineblan, og Grube anforer den ogsaa fra Omegnen af Breslan og Berlin. Ligeledes er den af Dr. Spangenberg fundet ved Nenstadt i Mecklenburg. I Sverige blev den Sommeren 1871 fundet af Prof. Lilljeborg ved Ronneby i Blekinge og, ifolge samme Forsker, opbevares i Stockholms Insem Exemplarer fia Stockholms Omegn og fra Hallands Väderö. Endelig har Dr. Hansson taget den i Bohnslän. Dens Udbredning strækker sig altsaa til folgende emropæiske Lande: Norge, Sverige, Tyskland og Frankrig. Andetsteds er den, saavidt mig bekjendt, ikke paatruffet, medminilre, som jeg er tilboielig til at tro, den amerikanske Form, Limnadia americana Morse, sknlde vise sig at være identisk med vor Art. shell of the egg is provided have probably their significance in the distribution of the eggs. When the ponds dry up, the eggs, together with the pulverised mud, may be easily canght up by the wind, and carried away to some distance. Such a distribution of the eggs by the help of the wind, I think, too, may be rlemonstrated at Mærdo. Besides in "Strrekjær», which seems to be the place to which this form has originally been confined, I met with it at several other points of the island, sometimes at a very considerable distance from the above-named little lake, and sometimes in snch small and shallow rain-ponls, that it was impossible to assume otherwise than that eggs have been quite accidentally carried thither from «Storekjær», by the wind. It appear's, however, that very special conditions are requisite if this Phyllopod is to thrive; for there were numerons small ponds on the island, some in the immediate neighbourhood of "Storekjær" where no trace of it whatever conld be discovered, although these same ponds seemed to be very farorable to the well-being of other Entomostraca. This also seems partly to account for the remarkably sporadic occurrence of this Phyllopod.

Distribution. - This species was first discovered by Herman in shallow ditches at Strassburg, where it has since been found again by v. Siebold. Brogniart fonnd it in small lakes at Fontaineblean, and Grube reports it also from the neighbourhood of Brestau and Berlin. It has also been found by Dr. Spangenberg at Nenstadt, in Necklenburg. In Swe. den, it was found in the summer of 1871, by Prof. Lilljeborg, at Ronneby in Blekinge, and, according to the same naturalist, there are in the Stockholm Musenm specimens from the neighbourhood of Stockholm and from Halland's Väderö. Finally, Dr. Hansson has taken it in Bolnuslën. Its distribution thus extends over the following European comntries: Norway, Sweden, Germany and France. Elsewhere it has not, as far as I am aware, been met witl, unless, as I am inclined to think, the American form, Limadia americana, Morse, shonld prove to be identical with our species. 


\section{Fam. Limnetidæ.}

Character. - Skallen stærkt buget, Talvlerne nden Taxtstriber og forbundne dorsalt med en ufuldkommen Laas. Horedet af enorm Storrelse, garende ur $i$ et nedadkrummet Rostrum af forskjellig Form lios de to Kjon. Trunens forholdsvis kort og massir; Halen rudimentær. 1ste Par Folere smaa og simple; - det Par forhuldsvis korte, men liraltige. Kindlakkernes Tyggedel stumpt tandet. ¿nlet Par Kjæerer rudimentære. Fodilemes Antal ikke overstigende 12 Par"; de ydre Enditer fingerformigt forlæugerle; knu 1ste Par hos Hannen preliensile. Forplantningen udpræget lisexnel. Udvililingen en compliceret Metamorphose, hegrndende med et eiendommeligt Naupliusstadium.

Bemærkninger. - Demme Familie er kum baseret paa en enkelt slregt, Limnetis, som dog synes mig $\mathrm{i}$ saa mange væsentlige Punkter at afrige ti'a de til foregaaemle Familie hemregnede slregter, at den fortjener at udskilles fru samme. Af Packard er den ogsaa opstillet som Typen for den ene af de $\because$ Underfamilier, hvori hans Familie Limmotindre leles. Het fortjener $\operatorname{dog}$ her at nærmes, at den til forregaaende Familie horende slaggt Cyclestherin i risse Forlold synes at rise en Tilnærmelse til næxrarende Familie, uden at den dog kan hemregnes til samme.

Gen. Limnetis, Lurén, $184 t$.

Syn. Hedessa Liùvin.

Slægtscharacter. - Skallen mere eller mindre kngleformig, glat, nden tydelige Umbuner. Hovedet kijolet efter Midten og fonlæuget til et hos Humnen mere eller mindre tilsundset, los Hannen træert aflinttet Rostrum; til Siderne af Horedet en vel udvililet bueformig Foruix. Haledelen meget liden, iklie ombriet og nden taulede Plader, men dirkket nedenunder af en operkelformig Lamelle. Umiddell,art foran den los Humen ¿2 tra den dorsale Flade af 'Truncus ndgaaende bladformige Plader. De sammonsatte Oie sammensmeltede i Midteu. Det enkle bie rel udviklet, Jeliggende nær de sammensatte Gine. Foran dem 2 tret sammenstillede cilierede Foldter. 1ste Par Eolere kolleformige; Odet Par merl trenene neppe langere end skaftet og delte i talrige lioute lueil, hvert linn harende en enlielt Srommeborste i Bagkanten. Overlæben simpel, ulen nogen tentakelformig Fortsats. -det l'ar Kiaver

\section{Fam. Limnetidæ.}

Characters. - Shell very tumid; the ralves without lines of growtl, and innected dorsally by an imperfect linge. Hear of enormous size, ending in a downward-curved rostrum of a different form in the two sexes. Trunk comparatively short and massive; tail rndimentary. First pair of antenne small and simple; 2nd pair comparatively short, but porverful. The masticatory part of the mandibles bluntly dentated. Second pair of maxille rndimentary. Numlier of legs not exceeding 12 pairs; the nuter endites digitiformly prodnced; only the 1st pair in the male prehensile. Propagation markedly hi-sexual. Derelopment a complicated metamorphosis, beginning with a peculiar nanplius stage.

Remarks. - This family is based upon only a single genus, Limnetis. which ret seems to me to differ in so many essential points from the genera belonging to the foregoing family, that it merits being separated from them. It has also been established Jy Packard as the type of one of the 2 sub-families, into which his family Limmadiade is divided. It is. lowever, deserving of mention here that the genus Cyclestheria, belonging to the foregoing family, seems, in certain points, to approan the present family, thongl it cannot be classed under it.

Gen. Limnetis, Lovén, 1s+6.

syn. Healessa livin.

Generic Characters. - shell more or less spherical, smooth, and without isistinet umbones. Head carinaterl medially, and produced in the female to a more or less pointed rostrum, in the male to one abruptly trumeated; at the sides of the head a welldevelnped arcuate fornix. Caudal part rery small, not bent dowwards, and without dentated lamellæ, but covered beneath by an operenlar lamella. lmmediately in front of it in the female, there are two foliate lamelle issuing from the dorsal surface of the trunk. The componnd eres merged together in the middle. Ocellus well-dereloped, situated near the compound eyes. In frout of them two juxtaposed, ciliated fields. First pair of antenna clavate; end lair with the rami soarcely longer than the seape, the former composed of numerous short joints, each carrying only at single natatory bristle on the lind margin. Labrum simple, without 
kun lestanende af to simple Lamelles, nulen enhves Beralming. Fodklerne los Hunnen 12 Par, hos Hamen 10 Par; den dorsale Lap af Exopoditen paa de 7 forreste Par enormt udviklet, paa : de og 10de Ear hos Humnen onformet til eylindriske omboiede strenge. Aggene ongivne af en simpel Skal og* simmenhobede under den hagre Del af Humens skal til 2 kageformige Masser. Larren ved sin Udklækning forsynet med et stort, flart liygskjold.

Bemærkninger. - benne Silægt er opstillet i Aaret $18+6$ at Lovén for en sydafrikansk Art, $L$. Halbergi. Ten kort Tid efter af Livin opstillede S'lagt Hedessa er identish med Lovén's slagt. Man kjender ialt s eller ! forskjellige Arter, som clog iklie alle el tilstrakkeligt characteriserede. Slægten synes at have en meget vid geographisk Udbuedning, idet Reprasentanter er fundne i samtlige Verdenalele. Hos os forekommer kinn én Art.

\section{Limnetis brachyurus, (Irill.)}

\author{
PI. XIIII-XX).
}

Lyncens brachyures, O. F. Müller, Entomostraca, p. 69, Tab. VIII, figs. $1-12$.

Hedessa Sieboldi, Lièvin, Schriften des naturt. Gesellsch. in Danzig, Bd IV, Heft II, p. 4, Tab. I. II.

Hedessa brichyura, siebold, Preuss. Provincialbl. 184!, Bd. VII, Heft 3, p. $19 \mathrm{~s}$.

Limmetis brunchyurus, Grube, Archiv f. Naturgeschichte, Bd. XIX, p. 71, Tab. V-III.

Artscharacter. - Skallen, seet fra Sillen, rundargtig, nxsten ligesaa hoi som lang, den storste Hoide fortil, Rygkanten noget skraa og km sragt buet, de frie Kanter af Talrlerne damnende en nafhrudt Bue, Forenden meget breder en Bagenden: - seet ovenfra bredt cegformig, den storste Bredde bag Midten. Langs Dorsalsiden en dyb Fure, i hris Bund Valveme er forbundne med hinanden. Hoverlet hos Humen mesten saa langt, som Truneus, Torsalkanten jernt buet, Rostrum endende $i$ en skarpt tilspidset Fortsats, ved Basis af hrilken dea: er to korte laterale Fremsiring. Hoverlet hos Hannen liortere, Fostrum trart afknttet, uden nogen terminal Spids. Haledelens Endleflige hos Hannen betydelig mere forlrengede end hos Humen. lste Par Fodder hos Hannen med Haanden masten rvadratisk og bevalmet langs Inderkanten med en Rad af ! stærke, pladeformige Tænder, Kloen leformigt krummet og tilspidset i Enden, den subapicale Laj' temmelig smal, klotornigt indadkrummet, og borstebesat alene i Spilsen. Farven mork olivengron. Langden af Skallen inttil $t^{1 / 2} \quad 1 m m$. any tentacular projection. Sepond pair of maxille consisting of only two simple lamella, yuite muaned. Twelve pairs of legs in the female, in the male 10; dorsal lole of the exofmlite in the 7 foremost pairs enormously developer, in the ?th and loth pairs, in the female, transformed into rylindrical corrls bent at the tip. Eggs suromeder by a simple shell, and accumulated beneath the hinder part of the female's shell, into 2 cake-like masses. The larva, when hatehed, funished with a large, flat ('axajace.

Remarks. - This genus was estallishen in the year 1840, by Lovén, for a Soutl African sprecies, L. Hahlbergi. The gemus Hrdessu, establisher a short time after by lievin is identical with Loven's genns. Eight or nine different speries are already known, not all, however, sufficiently characterised. The genus seems to have a very wide geographical distribution, representatives being found in all "uarters of the globe. Only one species ocen's in this countur (Normaý).

\section{Limnetis brachyurus, (Miill.)}

(Pl. XVIII-XI)

Lyncens brachymus, O. F. Miüler, Entomostraca, p. 69, Tab. V1II, figs. $1-12$

Hedessu Sieboldi, Lievin, Schriften des naturf. Gesellsch. in Danzig, Bu. IV, Hef't II, P. 4, Tab. I, II.

Hedessa brachyura, siebold, Prenss. Provincialbl. 1849, Bd. VII, Heft 3, r. 198.

Limnetis brandyurus, Grube, Archiv f. Naturgeschichte, Bd. IIX, p. 71, Tab. V-VII

Specific Characters. - Shell, seen from the side spheroilal, almost as high as it is long; the greatest height being in front; clorsal margin rather oblique and only shightly arched, the free edges of the valves forming an minterrupted onve: the anterior end much broader than the posterior. Seen from alore, the shell is broally orate, with the sreatest brealth behind the midlle. Along the dorsal surface, rims a deep furrow, at the bottom of which the valves are connected with each other. Head in the female almost as long as the trmik, dorsal margin evenly curved, rostrum ending in a sharply pointed projection, at the base of which there are two short lateral prominences. Hearl in the male shorter, rostrum alruptly truncated without any terminal point. Terminal lobes of the candal part in the male considerably more produced than in the female. First pair of legs in the male with the hand almost square, and anmed along the imner maroin with a row of ! strong, lamellar denticles; claw falciformly curved, and pointed at the extremity; sub-apical lobe rather narrow, bent inwards like a claw, and clothed with bristles only 
Bemærkninger. - Nææræærende Phyllopode er allerede i Aaret 1755 beskrevet af O. Fr. Hiiller som Lunceus brachyurus. At den senere som Hedessa sioboldi af Lievin opforte Form er identisk med Miiller's Art, er forst sikkert bleven constateret af (inube. Af de fra andre Verdensdele opforte Arter

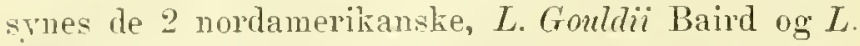
mucronata Packard at komme vor Art meget nær. Derimod afriger de 2 australiske Arter, L. macleayanu King og L. Tatei Brady, som jeg begge har havt Anleduing til at undersoge noiere, meget bestemt $\mathbf{i}$ Henseende tif Formen af Rostrum. Af den europriske Art har Grube givet en meget ndforlig og indgaaende Beskrivelse, ligesom han ogsaa forst har givet nærmere Oplysninger om dens eiendommelige Larvendvikling.

\section{Beskrivelse af Hummen.}

Skallem har hos de storste af mig indsamlede Exemplarer en Læungde af $4^{1 / 2} \mathrm{~mm}$. og en Hoide af $3,80 \mathrm{~mm}$. Den bestaar, som hos Limnadia, af 2 tydeligt begrændsede Valvler, forbundne med hinanden langs Dorsalsiden. Forbindelsen er temmelig nlig den hos Limnadia og gjor mere Indtryk af at være en virkelig Laas, i Lighed med hrad man finder hos Ostracoderne. Nedens nemlig hos den sidstnærnte Slægt de 2 Valvler stoder sammen oventil under en spids Vinkel, damner de her, for de forbinder sig med hinanden, en pludselig Omboining eller Fold, hvorved Forbindelsen mellem begge kommer til at ligge i Bunden af en dyb Fure, der strækker sig langs Rygsiden af skallen (se Tab. XVIII, Fig. 7 og 8). Seet fra Siden (Fig. 6), liar skallen en noget nregelmæssig rundagtig Form, med den storste Hoide, der falder nver den forreste Del, næsten ligesaa stor som Længden. Dorsalkanten er kun meget svagt buet og skraat heldende bagtil, forbindende sig med den bagre Kant nden nogen tydelig. Vinkel. Fortil er der en noget fremspringende, men afundet Forhoining, hror Dorsalkanten forbinder sig med Forkanten. De frie Kanter af Valvlerne danner en fuldkommen jevn og uafbrudt Bne, som dog er noget fladere fortil, hvorfor ogsaa skallen viser sig fortil ligesom stumpt afkuttet, medens den bagtil er mere jevnt afrundet. Seet ovenfra (Fig. 8), viser Skallen sig orerordentlig stærkt buget, bredt regformig, mer den storste Brede bag Nidten, og noget mere afsmahnende fortil end bagtil, hror den pludselig indsnævres til en kort stump Fremragning. Naar, som sædranlig er Tilfældet, Valvleme er halvt aabme (se Fig. 2), srnes Skallen, ovenfra eller nedenfra seet, end bredere og næsten fuldstændig kugleformig. Dreies Skallen saaledes, at the point. Colonr, a lark olive-green. Length of the shell, up to $4^{1 / 2} \mathrm{~mm}$.

Remarks. - This Phyllopod was described by 0 . Fr. Wüller as early as the year 1785, under the name of Luncens brachynus. That the form subsequently described by Lièvin as Hedessa Sieboldi is identical with Mïller's species, was first proved with certainty by Grube. Of the species described from other quarters of the globe, the 2 North American species, L. Gouldii, Baird, and L. mucronata, Packard, seem very much to resemble our species On the other hand, the two Australian species, $L$. macleayann, King, and L. Tatei, Brady, both of which I have had the opportunity of examining minutely, differ very decidedly in regard to the form of the rostrum. Grube has given a very detailed description of the European species, and was also the first to give any exact information about its peculiar larval development.

\section{Description of the Female.}

In the largest of the specimens collected by me the sliell has a length of $4^{1 / 2} \mathrm{~mm}$. and a height of $3.80 \mathrm{~mm}$. It consists, as in Limnadia, of 2 distinctly defined ralves, connected with one another along the dorsal side. The connection is rather unlike that in Limnadin, and gives more the impression of an actual hinge, such as is found in the Ostracods; for while in the latter genus the 2 valves meet above in an acute angle, they here, before joining one another, form a sudden bend or fold, thereby cansing the comnection between them to lie at the bottom of a deep furrow, which extends along. the dorsal side of the shell (see Pl. XVIII, figs. 7 and 8). Seen from the side (fig. 6), the shell has a somewhat irregular, rounded form, with the greatest height, which falls over the foremost part, almost equal to the length. The dorsal margin is only very slightly curved, and inclines obliquely backwards, miting with the lind margin withont any distinct angle. In front there is a very projecting but rounded prominence, where the dorsal margin: mites with the anterior. The free edges of the valves form a perfectly even and uninterrupted curve, which, however, is rather flatter in front, thus cansing the shell to appear anteriorly as if bluntly truncated, while at the back it is more evenly rounded. When seen from above (fig. 8), the shell appears to bulge very much, and is broady ovate, with the greatest breadth behind the middle, and rather more tapering in front than behind, where it suddenly contracts into a short, blunt projection. When, as is nsually the case, the valves are half open (see fig. 2), the shell, when seen from above or below, appears still broader and almost spherical. When the shell is turned in surh a way 
at man faar se den lige forfra (Fig. 7), viser den sig at have sin storste Brede nærmere Dorsalsiden, medens Talvlerne nedad stoder sammen under en temmelig spids Vinkel. Den dorsale Fure viser sig i deme Stilling af Skallen som en dyb Indbutning oventil. I den forreste Del af hver Valvel sees mere eller mindre tydeligt den rundagtige Insertionsarea for Skallens Lukkemnskel og uniddelbart bag denne Skalkjærtelen. Deme sidste (se Tab. XIX, Fig. 16) viser i alt vasentlig samme Bygning som hos Limnadia, men er forholdsvis kortere og bredere.

Skallens Overflade er ganske glat, uden Spor af Vextstriber. Rigtignok sees under visse Belysninger, i nogen Afstand fra Valvlemes frie Kanter, ligesom en svag buet Linie (se Tab. XVIII, Fig. 6), men jeg har overbevist mig om, at dette ikke er nogen virkelig Vrextstribe, men skriver sig fra den Omstændighed, at Valvlernes Randparti viser en noget anden Structur end den ovrige Del, noget ler ogsaa er bemærket af Grube. Skallen bestaar forovrigt, som hos Limmadia, af 2 Lameller, en ydre temmelig stærk, men megret elastisk chitinos Lamelle, $o g$ en særdeles delikat indre Membran, der damer en Fortsættelse af Legemets Integument. Ved meget stcerk Forstorrelse viser Skallens ydre Lanelle regehmæssige rundagtige Masker eller Fordybninger. Kanterne af Valvlerne er noget fortykliede og fuldkommen glatte.

Selve legemet er (se Tab. XIX, Fig. 1) frestet til Skallen paa en fuldkommen lignende Naade som hos Limnadia, nemlig verl et smalt dorsalt ligament, der urdgaar indad fra Skallens mest fremspringende Del, og i nogen Afstand under dette ved Adductormnskelen. Legemet er paa deme Maade ophængt paa en lignende Naade som hos hin Slrgt i Skallens Hule, saaledes at baade den forreste og bagerste Del er frit bevægelige. I Forhold til Skallen er imidlertid Legemet hos nærværende Form meget mere voluminost end hos Limnadia, hvorfor ogsaa i Regelen, saavel hos levende som Spiritus-Exemplarer, en storre Del af Hovedet rager firem af samme fortil (se ogsaa Tab. XVIII, Fig. 1 og 2). Ved en meget stærk Boining af Hovedet, horvel dette lagges ind mod Bugflarlen af hroppen, kan dog dette, ligesom let ovrige Legeme, helt inddrages indenfor Valvleme, som da slutter tæt sammen overalt. Som hos Limnadia, falder Legemet naturligt i 2 Hovedafsnit, et forreste $\mathrm{og}$ et bagerste, hegrændsede fra hinanden ved det dorsale Ligament og Skallens Lukkemuskel; men Forholdet mellem disse 2 Afsnit er her et helt andet, idet ret forreste er fuldkommen ligesaa stort som det hagerste. Begge Afsnit lader sig igjen dele i 2, det forreste i Hovedet og Nakkesegmentet, det bagerste i 'Truncus og Halen. as to be seen from straight in front (fig. 7), its greatest breadth appears to be nearer the dorsal side, while the valves meet below in a rather sharp angle. The dorsal furrow, in this position of the shell, is like a deep hollow above. In the front part of each valve is seen, more or less distinctly, the round area of insertion of the addnctor muscle of the shell, and immediately behind this, the shellgland. The latter (see Pl. XIX, fig. 16) exhibits, in all essential particulars, the same structure as in Limnatiu, but is comparatively shorter and broader.

The surface of the shell is quite smooth, without a trace of lines of growth. It is true that in certain lights, what appears to be a taint, curved line is visible at some distance from the free edges of the valves (see PI. XVIII, fig. (i); but I am ronvinced that this is no true line of growth, but is due to the circumstance that the marginal portion of the valves is of a somewhat different structure to the other part, a fact which has also been ubserved by Gurube. In other resprects the shell consists, as in Limnadia, of 2 lamellæ, an extermal, fairly strong, but very elastic, chitinous lamella, and an internal extremely delicate membrane, which forms a continuation of the integument of the body. Under a very high magnifying power, the external lamella of the shell exhibits regularly rounded meshes or hollows. The edges of the valves are somewhat thickened, and perfectly smooth.

The body itself (see Pl. XIX, fig. 1) is attached to the shell in exactly the same way as in Limnadia, namely, by a narrow dorsal ligament which runs inwards from the shell's most prominent part, and at some distance helow this, by the adductor muscle. The body is thus suspended in the cavity of the shell in the same way as in Limadia, so that both the fore and the hind parts can be moved freely. In proportion to the shell, however, the body in the present form is much more voluminous than in Limnadia, and consequently, as a rule, a large portion of the head, both in living and in spirit specimens, projects from the shell in tront (see also Pl. XVIII, figs. 1 and 2). By a very great flexure of the head, however, whereby it is lient in against the rentral surface of the body, it can, like the rest of the body, be completely drawn into the shell, when the valves fit closely together all round. As in Limnatia, the body falls naturally into two principal sections, one anterior and one posterior, separated from one another by the dorsal ligament and the adductor muscle of the shell; lont the proportion of these 2 sections is here puite different, the anterior. one being fully as large as the posterior. Both seetions admit of sub-division into 2 , the anterior into head and cervical segment, the posterior into trunk and tail. 
Hoverlet (se Tab. NIX, Fig. $10 g$ 11) er af enorm Storrelse, og viser, seet fra viden, en masten lolvmaanerlannet Form. Thet fortactter sig nedad umidrlelbart $i$ et srerdeles stort, lpformigt krummet lostrum, der er rettet slimat nelad og lagud. bets dorsale Kant er kjolfumigt tilskjapet og damer en fuldkommen jern og natbondt Pne lige til spidsen af Rostrum. Til hrer Sille sees en anden meget tvdelig og noget nregelmassig bugtet Kjol, hvorved Hovedets Sicleflaler deles i en dorsal og en ventral Area. Trenne Kjol, der aabenbart svarer til den saakaldte Funix hos Cladocereme og navmlig viser en umiskjendelig Lighed med samme hos Lynceiderne, begwnder ved Kimlbakliernes Freste ug strokker sig hertira med on ganske svag Krumning skiaat tortil, henimod Jiriten af Hovedet. Lrengde, hrorpaa den g.jol en meget stæerk, næsten vinkelformig Boining og lober skrat bagtil langs Siderne at Rostrmm, emlende med et kort tandformigt Fremspring i nogen Afstand fra spricken. Sees Hovelet lige fortra (Tab. XVIIl, Fig. t), viser demme laterale Kjol ig starkt fremspringende $i$ sin proximale Del, idet den her som et Hraly dakker over Basis af darerne. Langere nedad næmmer de 2 Kjole sig til hinanden og gin derved Indtryket af an tyolelig lndknibning at Horedet vel Basis at Rostrum. Dette sidste viser sig i lenne Stilling af Hovedet ligesom tredelt i Enden, gaaende i Midten ud $i$ en stærli dolliformigt tilspidset Fortsats, og til hver Sicle af denne $i$ et betrdelig kntere tandformigt Fremsiring: der danner Enden af re laterale Kiole.

Nakliesegmentet (se Tah. NIX, Fig. 1 og 11) er ganslie kort og begrendset fra Hovedet ved en vel markeret Traesutur, ved hris Ender Kindbakkernes ove Del er fiestet. Det er ganske sragt hvelvet oventil og riser til hrer side en kort. slirat ojadgaaende Ribbe, der jar en Maade er en Fortsattelse af' Hoverlets laterale Kjole.

Truncus er omtrent af Hovedets Læengle og temmelig tyli fortil, men afsmalnes hurtigt $o g^{\circ}$ jevnt bagtil. Then er delt i 12 uniforme Segmenter, hvert bærencle et Par Branchialfodder. Dorsalsiden af Segmenterne er ganske glat, mlen Borster. Derimod udgar fra Siderne at de 2 bagerste Segmenter et l'ar eientommelige, lateralt udbredte Plader, hrortil intet tilsvarende findes hos andre Plyylopoder. Irise Plarler (1'ig. !), 1), som alene forefindes hos Hunnen, er af ikke nbetrdelig Storrelse, bladformige, og gaar unl i 3 triangulæut tilspirlsede Flige, hvorat den forreste er storst. Itolge sin sitilling synes de næmest at vere bestemte til at stotte de 2 kageformige Isgmasser, som bæres mnler skallen.
The head see l'l. NIX. figs. 1 and 11 ) is of enormous size, and when seen from the side, exhibits an almost semi-lumar shape. It is continued downwards into an exceedingly large, falciformly curved rostrum, which points oblipuely downwards. and backwards. Its dorsal margin is sharpened in the form of a keel, and forms a perfectly even and minterrujted curve right to the point of the rostrmm. On each sile is visible another very distinct, and somewhat irregnlarly wary keel, by which the lateral surfares of the head are divided into a dorsal and il ventral area. This keel, which evidently answers to the so-ralled fornix in Cladocera, and notably exhibits an ummistaliable resemhlance to that in the Lynceidre, commenues at the place of attachment of the mandibles, and luns thence with a very gentle curve oblinnely forwards to abont the middle of the length of the head, where it makes a very sharp, almost angular bend, and run: backwards along the sides of the rostrum, ending in a short, dentate projection at some listanre from the point. When the head is seen from the front (Pl. ITIII. tig. 4), this lateral keel appears very prominent in its proximal part, where it covers the base of the oars like an arch. Fartler down, the 2 keels approach one another, thereby giving the impression of a distinct contraction of the head at the base of the rostrum. The latter appears, in this position of the hearl, as if tripartite at the extremity, being prodneed in the middle to a strong. muronate projection, on each sicle of which is a considerably shorter, dentiforn prominence, forming the end of the lateril lieel.

The cervical segment (see P1. XTX, figs. 1 and 11) is rnite slout and separated from the liead by a well-marked transverse suture, to the ends ot whirh the mpper portion of the mandibles is attacherl. It is very slightly arched above, and shows, on each side, a short, oblinuely-ascending bar, which in one way is a continuation of the lateral lieel of the head.

The trunk is of abont the same length as the head, and rather thick in front, but tapering rapidly and evenly behind. It is divider into 12 uniform segments, earh carrying a pair of branchial logs. The dorsal surface of the segments is quite smooth, and without bristles. On the other hand. fiom the sides of the two hindmost segments, there issnes a pair of peculiar, laterully-extended lamina, to which there is nothing corresponding to be found in other Phyllopoda. These lamina (tig. 9.1) which are only found in the temale, are of no inconsiderahle size, are toliate and project into 3 triangularlypointed lobes, of which the foremost is the largest. Julging from their position, they alpear to be intenderl to support the " cake-like masses of egg's that are carriel beneath the shell. 
Halen (Fig. 7, 8) er meget liden og ındimentrer, ikke omboiet, og kan heller ilike i Regelen strolikes synderlig langt nd fra Skallen. Den ender i 2 skraat nedadrettede og jevnsides liggende Flige af triangulær Form ug tæet cilierede i Kanterne, liver barende i Spidsen en liden, som det synes, fuldstandig whevægelig. 'Torn, der aabenbart svares til Haleklorne hos andre bivalve Phyllopoder. Dorsalt findes omtrent paa Milten af Halen et stumpt Fremspring, hrortil de 2 Haleborster er fastede. Disse er vel udviklede, tydeligt 2leddede og tæt cilierede. Halens ventrale Side er delvis drekliet af en eiendommelig, operkelformig Plade (op), der udgaar fra dens Basis, og hrortil intet tilsvarende lijendes los andre Phylloporler.

De sammensatte Gine (Fig. 11,o) er beliggende nær Forkanten af Hovedet, ontrent ved Enden af den 1ste Trediedel af lets Lingde. De er forholdsvis smaa $o g$ stoder umidlelbart sammen i Midten, saa at de egentlig tilsammen danner et enkelt Organ, paa hvilket dog de 2 oprindelige Halvdele let lader sig paavise, nar Organet sees forfra (Ta). XVIII, Fig. 4) eller nedenfra (Ta], XIX, Fig. 13,o). De er omgirne af en frelles Kapsel og viser et stort Antal af smaa Krystalkegler udstraalende til alle Sider fra det morke Pigment. Som hos Limnadia, er de til en vis Grad berægelige ved Hjælp af 3 fra Hovedets Integument til hrer Halvdel udgaaende Nuskler (se Fig. 11).

I ganske kort Afstand nedenfor de sammensatte Oine ligger det enkle Oie (Fig. 11, 13, 14, oc, Fig. 15). Det er af en noget uregelmæssig afrundet eller rettere kubisk Form og viser ved noiere Undersogelse, ligesom hos Limnadia, 4 Flader indrammede af et morkt Pigment. Fladerne er temmelig strerlit ndbnede og viser muder visse Belysninger en lignende iriserende Glands som hos hin Slægt. Det er holdt i Situs red fine til Hovedets Integument gaaende Ligamenter, hvoraf et fæster sig til Forkanten af Hovedet ved Basis af Rostrum (Fig. 11, p).

Uniddellart foran det enkle Gie bemerkes i Hovedets Integiment 2 jevnsides stillede aflangt ovale Felter (Fig. 11, ol), der er meget skarpt conturerede og har til Underlag en blod Masse af tilsyneladende ganglios Natur. Ethvert af disse Eeldter (se Fig. 12) er dakket af en meget delirat Membran, hrorfra et Antal af fine Haar eller Gilier springer frem, hvert udgarende fra en liden knopformig Fortykkelse i Membranen. Der kan neppe være nogen Tvivl om, at disse eiendommelige Lannelser, der ogsaa er omtalte af Grube, representerer et Slags Sandseredskaber, men af hvilken Art er vanskeligt at sige. Endnu en eiendommelig Dannelse maa her omtales. Folger man Dorsalkanten
The tail (figs. $i$ and 8 ) is rery small and rudimentary, is not bent domm. and comuot as a rule be extended very far from the shell. It ends in ? obliquely-pointing, juxtaposerl lobes of a triangular shape, and thickly ciliated at the erlges, each "ar. rying at the point a small, apparently puite immorable spine, which evidently answers to the caudal claws in other hi-valved Phylloporla. At ahout the middle of the tail dorsally there is a blunt projec. tion, to which the 2 caudal setre are attached. The latter are well-developed, distinctly "-jointed and thickly ciliated. The rentral surface of the tail is partly covered hy a peculiar operenlar lamella (op . issning from its base, and to which there is nothing corresponding in other Phyllopoda

The compound eyes (fig. 11,o) are sitnated near the front margin of the head, at abont the end of the first third of its lengtls. They are compraratively small, and meet in the middle, thus forming in reality a single organ, in which, however, the 2 original halves may be easily distinguished, when the organ is seen from the front (Pl. XVIII, fig. 4) or from below (Pl. XIX, fig. 13. o). They are surrounded by a common capsule, and exhibit a large number of small crystalline cones radiating to all sides from the dark pigment. As in Limmulia, they are movable to a certain extent by the help of 3 muscles issuing from the integmment of the head to each half (see fig. 11).

At a rely short distance below the compound eyes, is the orelhus (figs. $11,13,14 o c$, fig. 15). It is of a somewhat irregular, rounded or rather entical shape, and presents, on a closer examination, just as in Limnadia, 4 surfaces encircled by a dark pigment. The surfaces are not a little convex, and in certain lights, like the above-mentioned genus, have an iridescent lustre. It is held in position by fine ligaments ruming to the integument of the head, one of which is fastenerl to the anterior margin of the head at the base of the rostrum (fig. $11, p^{\prime \prime}$.

Immediately in frout of the ocellus, may be observed, in the integument of the head, 2 juxtaposed oblong oral fields (fig. 11. ot) very sharply ontlined, and with a soft mass of an ap. parently ganglionic nature as sub-stritum. Each of these fields (see fig. 12) is corerel by a rers delicate membrane, from which suring a number of fine hairs on cilia, each issuing from a little nodiform thickening of the membrane. There can hardly be any doubt that these peruliar formations, which are also mentioned by Grube, re present a kind of sensory apparatus, but of what kind, it is difficult to say. Yet nother yeculiar formation must be mentioned here. In following 
af Horedet oporel, vil man helt bagtil, i nogen Atstand fra den traergaende Sntur, der skiller Huverlet fra Nakkesegmentet, bemærke en liden grubeformig Fordyluning (Fig. 11, x), del romstant forekommer lrer hos alle Individer, baade Hanner og Hunner. Ifolme sin Plads maa demne Grube nærmest ansees for lromolog med Fastheftningsorganet hos Limmadia, skjondt det er lidet troligt, at denme uhetydelige Grube kan her fungere som et saadant irgan.

Forste Par Folere (Fig. 11, a ${ }^{1}$, Fig. 2), som er frestede til hvel side af Hovedets rentrale Del, middelbart foran Basis af Orerichen, er meget smaa og af noget liolledannet Form. De bestaar hver af et hort Sliaft $\mathrm{og}$ en noget luuet, i sit ydre Parti fortrkiet Endedel, der fortil er tret besat med lelicate Lngtepapiller (Fig. 2 a), af et lignende Udspente som hos Limatir. Tlisse Folere el til en vis (trad bevegelige red Hjælp af en Del smaa Muskler, som passerer til dem fra Hovedets Integument.

Andet Par Folere, eller Aarerue (Fig. 3), ud. suringer. som hos Limmatia, med en bred Basis tra Hovedets sider, middelbart under ien bagre, mest trensplingende Del at Fornix. De bestar af de samme Tele som hos Iimmatia, nemlig et tykt, "ylindriskt Skaft, og 2 Grene; men disse sidste el her paa langt nar iklie saa strrkt forlæugede som hos hin Silrgt. Skaftet, hvis hasale Del synes at vere tuldstæudig nberæagelig, er clerimod paa Midten meget boieligt og lier delt i flere korte, tillels ufuldstandigt sondrede Lerl, medens dets rdre Trediedel damer et enkelt Led for sig. Fra Basaldelen unwarr bagtil et Antal af omkring 5 stærle nedadrettede Fjarlorster, og i Forkanten af det rderste af' de mediane Led er der en Del grove Pigge, ordnede i en Trarrad. En lignende Trrerad af Pigge findes ogsaa red Enden af Skaftet fortil. Grenene er neple længere end skattet og omtrent af ens Storrelse, eller den bagre ubetydeligt længere end len forreste. De er begge delte $;$ et stort Antal (fia 15 til 18) korte Led, ler dog verl Basis af Grenene er meget utrdeligt sondrede. Ethrert Led har i Sagkanten en enkelt lang Srommeborste, og paa den forreste Gren lar de Heste led endnu livert en enkelt stark Pig i len modsatte Kant. Sidste Led har par den bagre firen 2 Srommeborster, paa den forreste restonulen en Pig. Naar Aarerne er i Hrile, laggges de almindeligris langs ad Siderne af Hovedet, miiddelbart bag dettes laterale Kijole. De fira Hovedets Integument til Aarerne gaaende Muskler er meget krattige ug foster sig alle ved det midterste boielige Parti af skaftet. I dettes ydre llel sees anlle Mnskler, del virlier pa enlover af irenene. the dorsal margin of the head uprards, there is observable, at the rery back, at some distance from the transvelse suture. which separates the head from the rel'vical segment, a small pit-like repression (fig. 11, x), which oceurs invariably in all specimens, both males and females. Fron its place, this pit must mobably be regarded as homologous to the organ of attachment in Limmadia, although it is almost incredible that this insignificant hollow can here act as such an organ.

The lst pair of antennæ (fig. 11, a ${ }^{1}$, fig. 2) which are attached to the sides of the rentral portion of the liead, immediatel $Y^{*}$ in front of the base of the labrum, are very small, and of a somewhat clavate form. They each consist of a short scape, and a somewhat curved terminal part, thickened in its onter portion, and thickly set in front with delicate olfactor' papillæ (fig. 2 a), of an appearance similar to those in Limmotia. These anteme are movable to a certain extent by the aid of sereral small muscles passing to them from the integmment of the head.

The second pair of antenne, or the oars (fig. 3) issue, as in Limmatia, with a broad base from the sides of the head, immediately below the hinder, most projecting part of the fornix. They consist of the same parts as in Limmaria. namely a thick, crlindrica! scape, and 2 rami; but the latter are here not nearly so much elongated as in the beforementioned genus. The scape, of which the basal prat apjears to be quite immorable, is, on the wher band, very flexible in the middle, and is here divided into sereral short, to some extent imperfectly defined joints, while its ristal third part forms a single joint by itself. From the basal part there issue at the back about 5 strong, downwardpointing plumose setre, and on the anterior margin of the most listal of the median joints, there are a number of coarse spines aranged in a transverse row. A similar transwerse row of spines is also found at the end of the scape in front. The rami are scarcely longer than the scape, and are of almost equal size, the hind one being very slightly longel than the front one. They are buth divided into a great number (from 15 to 18) of short joints, which, however, are very indistinetly defined at the base. On the hind margin of each joint, there is a single long natatory bristle, and on the front. ramus, most of the joints have yet another single, stromg spine on the oprosite margin. On the hinr? ramus there are 2 natatory bristles on the last joint, and on the front ramus, a spine as well. When the oar's are at rest, they generally lie along the sides of the head, immediately behind its. lateral keel. The muscles ruming from the integriment of the head to the oars are very powerful, ancl are all attached to the midlle, Hexible part of 
Orerbben (Fig. 11,L), som danner ten umidlelbare Fortsattelse af Hovelets ventrale Elarle, er af betydelig Storrelse og rakker ind mellem Basis af 1ste, tildels endogsaa 2det Foulpar. Wen har Formen af en aflang, noget sammentrylit Lap, der i sit vdre Parti danner en noget nedalboiet, mundtom fint cilieret oval Lamelle, nden nogen sadan tentakelformig Fortsats som hos Limmatia. Overlæben kan loftes af fra Mundelene verl et Par tynde Muskler, der fra Hovedets Integmment passerer til dens Basis. I rens Indre sees, som hos Limmatia, flere celleagtige Legemer og et Antal af trarganende IIuskler, som virker paa dens ove blode og rendeformigt forlybede Flade.

Tindbakkerne (Fig. 4, Fig. 11, il) ligger, som hos Limatia, i Form af 2 boiletomige Legemer til hrer Sille paa Græendsen mellem Hovedet og Nakkesegmentet. Deres ove tilspidsede Ende er articuleret til et fortykket Parti af Integumentet red Enderne af den mellem begge de oremmernte Dele gaaende 'Trærsntmr, medens deres nedre, strerkt indboiede Ender modes paa Undersiden ved Mundaabningen. Trggedelen er starkt, nasten oxeformigt udvidet, og viser en noget tilskjerpet liant lelt i en Rakke stumpe Tæuder, hroraf clen yclerste er storst. I sin Bevæbning skiller altsa Kindbakkerne hos nærvarende Form sig meget rasentligt fra samme hos de ovrige bivalve Phyllopoder og viser en Tilnrermelse til den for Apotiderne characteristiske Bygning.

Forste Par Kjærer (Fig. 4, 11, $m^{1}$, Fig. 5), bestaar, som hos Limmadia, af en tykkere Basaldel og en bevagelig Endeplade; men denme sidste er her betydelig smalere, leformigt indadlirummet, og kun forsynet med et begræudset Antal af stærke, nleddede Borster. Langs den indre Kant af Pladen tæiler man 8 saadanme Borster, noget tiltagende i Lrengde ndad og fint cilierede $\mathrm{i}$ den ene Kant (se Fig. 5a). Ved Spidsen af Pladen er frstet 3 betydelig kortere Borster, der er pigformige og grort tandede i begge Kanter (se Fig. 5 b). I den rille Kant har Pladen red Basis en meget fin Ciliering:

Andet Par Kjæver (Fig. 4, 11, $^{2}$, Fig. 6), der ikke er bemarkede af Grube, er meget rulimentære, kun forestillende et Par simple, noget hjerteformige Lameller af en delikat membranos Beskaffenhed, i hvilken Henseende de nærmest synes at svare til den ydre Udvidning (Palpe) af disse Kjæever hos Lepidurus. Deres Beliggenhed, temmelig langt fjernede fra Midtlinien (se Fig. 4), taler ogsaa for en saarlan Tydning, livorved altsaa den egentlige Tyggedel maa antages at rære ganske oblitereret. Lamel- the scape. In the outer part of the latter, other muscles are visible, which act mpon each of thr rami.

The labrum (fig. 11, L), which forms an inmediate continution of the rentral surface of the head, is of considerable size, and extends between the luases of the 1st, and pratly also of the end pair of legs. It has the form of an oblong, ra. ther compressed lobe, whose onter part forms a somewhat downward-cnrved, oval lamella, finely ciliated all round, and withont any snch tentacnlar projection as in Limnulia. The labrum can be raised from the oral parts ly a pair of thin muscles passing to its base from the integument of the heal. In its interior may be seen, as in Limnadia, severa] cellular lodies, and a numbej of transverse muscles, acting upon its npper soft and groored smrface.

The mandibles (fig. 4 , tig. 11, $I$ ) lie, as in Limnartia, in the shape of 2 bow-shaped bodies, one on each side: at the boundary between the head and the cervical segment. 'Their upper pointed end is articnlated to a thickened part of the integument, at the ends of the transverse snture which runs between the two parts just named; while their lower, much incurved ends meet on the mnder surface at the oral aperture. The masticatory part is strong, and almost securiformly expanded, and exhibits a somewhat sharpened edge, divided into a series of blunt teeth, the outermost of which is the largest. Thus, in the matter of eqnipment, the mandibles in this form are very essentially diatinct from those in the other bi-valve Phyllopoda, and show an approach to the structure characteristic of the Apodide.

The 1st pain of maxillæ (figs. 4, 11, m ${ }^{1}$, fig. 5 consist, as in Limmatia, of a thicker basal part anul a movable terminal lamella; but the latter is here considerably narnower, is curved falciformly inwards. and fumished with only a limited number of strong; martimlated bristles. Along the inner edge of the lamella, 8 such bristles may be comnted, somewhat increasing in length outwarks, and finely ciliated on one edge (see fig. 5 a). To the point of the lamella are attached 3 considerably shorter bristles, which are spiniform and coarsely dentated on both edges (see tig. 5 b), At its base the lamella is very finely ciliated on the onter margin.

The second pain of maxilla (figs. $t, 11, \mathrm{~m}^{2}$, fig. 6), which have not been observed by Grube, are very rudimentary, representing only a pair of simple, somewhat cordate lamellæ of a delicate, membranons consistency, in which respect they seem almost to correspond to the onter expansion (palp) of these maxilla in Lepirlurus. Their position, at some distance from the median line (see fig. 4), also favours such an interpretation, whereby the true masticatory part must be assmmed to be guite 
lerne srnes til en ris (rrad at rae bevagelige, idet ? tynde Nuskler praserer til hrer af dem ovenfra.

Branchialfoldernes Antal er, som ovenfor anfort, 12 Par. Af disse er de 3 forreste Par omtrent at ens Langde, medens de ovrige hurtigt aftager i Storrelse bagtil. Tab. XX, Fig. 1 fremstiller en Fod af Bdie Par seet fra ren forreste Flade. Som det vil sees, er Formen temmelig afrigende fra samme hos Limnadia, skjondt man kan adskille de samme Horeddele. Endopoditen er illethele bredere og mere pladeformig, ug af Enditerne har kun de 2 inderste et lignende Udseende som dem hos Limnatia, merlens de 3 derpaa folgende er forlangerle til tingerformig indadrettede Fortsatser besatte $i$ den ene Kant med en dobijelt Rad af stærke Borster. Den rderste (5te) Endit er, som hos Limmadir, berægeligt articuleret til Endoporliten og forestiller egentlig demmes Endeled. Coxallappen (mx) er rel ndviklet og skraat indadrettet, visende adskillig Lighed i Form med Endepladen at' 1ste Par Kjæver. Ilen er imidlertid (se Fig. 1 l) forsuet med et storre Antal Borster $i$ den indre Kant, tildels ordnede $\mathrm{i} 2$ Rekker. Yderkanten har kun en enkelt indarlettet Borste nær Spidsen og er forovrigt meget fint cilieret. Epipoditen (ep) er af middels Storrelse ng viser en lignende Form og structur som hos Limmatia. Derimod har Exopoditen et temmelig afvigende Udseende. Den er rigtinnok ogsaa her deit $\mathrm{i}$ en ventral og en dorsal Lap; men den rentrale Lap (ex), som hos Limnatia er den storste, er her kun tilstede som en forholdsvis ubetydelig, smalt tilspidset Fortsats, kantet mesl lange, cilierede Borster, medens den dursale Lap (ex ${ }^{1}$ ) er enormt udviklet, dannende en brecl, halvmaaneformigt krummet Plade, der rager hoit op over Kropsiclerne (se Tab. XIX, Fig. 1). Denne Plade har langs Yderkanten en tat Parl at forholdsris korte, men tret cilierede Borster og er ogsaa tildels borstebesat i Inderkanten. Fra dens stumpt afrundede Ende udgaar desuden en meget lang og tynd. ucilieret Borste.

At' rasentlig samme Udseende som det urenfor beskrevne Bdie Fodpar el ograa de 2 forreste og de 4 folgende Par, hrille sidste dog gradris aftager i stomelse.

Bde Fodpar (Fig. 2) skiller sig imillertid, forulen ved ringere Storrelse, meget vasentligt red den fuldstændige Nangel af Epipodit. Ligeledes er Enditerne mere sammentrangte og mindre nlige, idet de 2 bagerste er mere fremspringende, de 3 rderste kortere end paa de foregaaenle Par. Exopoditens dorsale Lap er fursynet i Enden med flere lange, divergerencle Borster af samme Reskaffenhed som den enkle ajicale Borste paa 3die I'ar. obliterated. The lamellw appear, to a certain extent to be movable, as 2 thin muscles pass to each of them from above.

As stated above, the number of branehial legs is 12 pairs. The 3 foremost of these are of about uniform length, while the remainder rapidly diminish in size towards the back. P1. XX, fig. 1, represents a les of the 3rd pair seen from the front. As will be seen, the shape differs not a little trom that in Limnactia, although the same principal parts are distinguishable. The endopodite is on the whole broader and more lamellar; and only the innermost endites have a similar appearance to those in Limnadiu, while the next 3 are elongated into digitiform, inward-pointing projections, clothel on one edge with a donble row of strong bristles. The outermost (5th) endite, as in Limnactia, is movably articulated, to the endopoclite, really representing the latter's terminal joint. The coxal lobe $(\mathrm{mx})$ is well developed, and directed obliquely inwards, and exhibits a considerable resemblance in form to the terminal lamella of the 1st pair of maxilla. It is, howerer (see fig. $1 \mathrm{~b}$ ), furmished with a larger number of bristles on the inner margin, arranged to some extent in 2 rows. The outer margin has only a single inward-directed bristle near the point, and, in addition, is very finely ciliated. The epipodite is of medinm size, and exhibits a similarity in form and strmeture to that of Limnadia. The exopodite. on the other hand, is rather different in appearance. It is, indeed, here too, divided into a ventral and a dorsal lobe; but the rentral lobe (ex), which in Limmadia is the larger, here appears only as a comparatively insignificant, narrowly-pointed projection, edged with long ciliated bristles, while the dorsal lobe $\left(\mathrm{ex}^{1}\right)$ is enomously dereloped, forming a broal, crescent-shaped curved lamella, which extends far up orer the sides of the hody (see Pl. XIX, fig. 1). Along its outer margin this lamella has a close row of comparatively short, but thickly ciliated bristles, and is also setous to some extent on the inner margin. There also projects from its bluntly rounded end a very long, thin, unciliated bristle.

The 2 foremost pair's of legs, and the 4 succeding pairs are essentially of the same appearance as the aburedescribed 3rd pair, the $t$ succeeding pairs, howerer, diminishing gradnally in size.

The Sth pair of legs, however (tig. 2), besides being distinguished by their smaller size, differ very essentially in the total absence of an epipodite. The endites too are more crowled together and less dissimilar, the 2 hind ones being more projecting, and the 3 onter ones shorter than in the preceding pair. The dorsal lobe ot the exopodite is tnrnished at the extremity with several long, divergent bristles of the same appearance as the single apical bristle on the Brd pair. 
De 2 folgende (9de og 10de) Par (se Fig. 3) mangher, ligesom det sde, ganstie Epipodit, og udmarker sig desuden ved det eiendommelige Udseende af Exopoditens dorsale Lap. Tenne er nemlig paa hegge disse Par omformet til en cylindrisk Streng, ler er hageformigt omboiet i Enden og her forsmet merl en tret Ciliering: Det er aabenluart, at disse 4 Appendices se ogsaa Tab. XIX, Fig. 1, Fig. 9, fb) er bestemt til, i Folening med de ovenfor ontalte, fra Pygiden af de 2 bagerste 'Truncus-segmenter udgaaende, bladformige Plader (1), at stotte de 2 kageformige Egmasser, der breses nder skallens bagre Del.

De 2 sidste Foupar (Tab. XX, Fig. 4, 5) er meget smaa, narnlig det lagelste (12te) Par, og mangler baade Epipodit og den dorsale Lap af Exopoditen. Forovrigt ligner de i Structur de 2 foregarende Par, og har, som disse, alle Enditer, ligesom ogsaa Coxallappen, tydeligt udviklede, skjoudt meget tret sanmentrængte. Den ventrale Laj af Exoporiten er paa sidste Par (Fig. 5) reduceret til et fra den rdre Side af Endopoditen ndgacende meget lidet, med 5 Borster forsynet Appendix.

\section{Beskivelse af Hanten.}

Hamnerne er gjennemgaaende noget mindre end Humerne, idet Skallen neppe opnaar en Lengde af 4 mm. Den er ogsaa (se 'Tal). XVIII, Fig. 3) noget mere nregelmassig af Form, med Forenden mere trært afkuttet, og de nedre Kanter damende fortil en meget stærk, næsten rinkelformig Krumning. Forovrigt ligner Skallen samme hos Hummen og er fuldkommen ligesaa stærkt bnget som hos denne.

Det i Skallen indesluttede Dyr (se Tab. XI, Fig. (i) viser flere characteristiske Eiendommeligheder, hrorred det strax skiller sig fra samme hos Hnnnen. Hovedet er saaledes luetydelig kortere og Rostrum af en meget afrigende Form. Seet fra Siclen (se Tab. XVIII, Fig. 3, Tab. XX, Fig. 6) er det næsten jevnt bredt og har Enden, ikke som hos Humen ndtrukket til en skarp Spids, men stumpt atrundet. Forfra seet (Tab. XVIII, Fig. 5) viser det sig tvært afknttet i Enden, idet den mediane Spids ganske mangler, medens de laterale Fortsatser, hvori Hovedets Sidekjole gaar ud, er betydelig mere udstaaende end hos Hnmen og næsten retvinklede. At' de eiendommelige trefligede Blade, der hos Humnen udgaar fra Rygsiden af Trumeus bagtil, er der intetsomhelst spor at opdage (se Tab. XX, Fig. 6).

Haledelen (Fig. 10) har ogsaa en noget forskjellig' Form, idet de 2 Endeflige er betydelig stærkere forlængede end hos Humen og tæettere cilierede.
The 2 sncreeding (9th and 10th) pairs (see tig. : 3 ) are, like the sth, marked by a total alsence of an epiporlite, and are also distinguished by the peculiar appearance of the dorsal lobe of the exoforlite. In both these pairs, this lobe is convorted into a cylindrical cord, which is bent down at the end like a hook, and thickly ciliated. It is evident that these 4 appendages (see also Pl. NLX, fig. 1, fig. 9. $f$ b) are intended, in comjunction with the above-mentioner leaf-like lamelle (1) issning from the dorsal side of the 2 hindmost segments ot the trunk, to supjort the 2 cake-like masses of eggs, which are borne beneath the posterior part of the sliell.

The last 2 pairs of legs (Pl. XX, figs. 4, 5) are rery small, especially the hindmost (12th) pair, and are withont botls epipodite and dorsal lobe of the exopodite. In other respects they resemble the? mereding pairs in structure, and lave, like them, all the endites, as well as the coxal lobe, distinctly developed, atthongh very alosely crowded together. The rentral lobe of the exopodite in the last pair (fig. 5) is reduced to a rery small appendage projecting from the unter side of the endoporlite, and fumished with is bristles.

\section{Description of the Hale.}

The males, on an average, are rather smaller than the females, as the shell scarcely attains a length of $t \mathrm{~mm}$. It is also (see Pl. XVIII, fig. 3) rather more irregular in shape, with the anterior end more abruptly truncated, and the lower erlges forming in front a very sharp, almost angular curve. In other respects the shell resembles that of the female, and is quite as much vaulted.

The animal enclosed in the shell (see P]. XX, fig. (i) exhibits several characteristic peculiarities, thereby being immediately distingnished from the female. The head is considerably shorter, and the rostrum of a rerry different shape. Seen trom th's side (see Pl. XVIII, tig. 3; P]. XX, tig. 6), it is of almost even breadth, the end not being drawn out, as in the female, to a shary point, but being bluntly rounded. Seen from the tront (P]. XVIII, fig. 5), it appears abmptly truncated at the end, the median point being altogether absent, while the lateral pojections into which the side keels of the head are prodneed are considerably more prominent than in the female, and almost rectangular. There is no trace whatevel to he discoreled of the peculiar trilobed lamelle, which, in the female, issue from the dorsal surface of the trunk behind (see Pl. XI, fig. 6).

The candal part (fig. 10) is also of a somewhat ditterent shape, the 2 terminal lobes being cunsiderahly more elongated than in the temale, and more thickly ciliated. 
Hvad de forskjellige Lemmer angaar, saa riser de til det torreste Afsnit af Legenet horende neppe nogen vasentlig Forskjel fra samme hos Hummen, skjondt maaske 1ste Par Folere er noget storre og rigeligere forswnede med Lugtepapiller. Derimod hemærlies Here characteristiske Eiendommeligheder ver de til det bagerste Afsnit horende Lemmer eller Branchialfodderne. For det forste er deres Tal her constant et ringere, nemlig lim 10 Par ialt, og der'nrest er 1ste Par meget uligt samme hos Humnen. ilet det er omdannet til et Par særdeles kraftige Gribered-kaber, hrormed Hannen under Parringen fastholder Humnens Skal (se Tab. XX, Fig. 6). Fig. 7 fremstiller en Fod af dette Par, seet fra den forreste Flacle, og Fig. $s$ det rdre Parti af samme noget stærkere forstorret. Som det ril sees, er Exopoditen og Epipoditen, ligesom ogsaa Coxallappen, noget nær af' samme Udseende som hos Hum nen. Derimod er det terminale Afsnit af Endopoditen meget stierkt modifireret og omdannet til en med den proximale Del berægeligt forbunden Haand, ligesom de til dette Afsnit horende Enditer er eiendommeligt omformede. Selve Haanden er næsten qradratisk af Form, med den indre Kant, eller Palmen, strerkt bnet og berælmet med en Rad af ? meget strerke, noget plarlefmmige Pigge, mellem hrilke rager frem stive Borster. Den yderste Endit er omformet til en kraftig, leformigt indalkrummet Klo, der ulgaar med en noget udridet Basis fra Enden af Haanden og kan ved Hjælp af en Del Innskler boies ind moil de ovenomtalte Pigge. Ted Roden af deme Klo udgaar et andet Appendix, der sædranligris ogsaa er indadkrummet, men ender i en stump, med lange Borster besat Spils og som synes at forestille den næstsidste omformede Endit. Langere indad, mellem Kloen og de uvenomtalte Pigge er endelig fæstet nok et Apjendix, der er lige nedadrettet og har Formen af et ovalt Blad, tæt besat med Borster. Dette Blad srnes at representere den Blie silste Endit. Fra den proximale Iel at Endopoditen ndgan indad en enkelt bred pladeformig Udridning kantet med en dobbelt Rad af lange Borstel, og rimeligvis fremkommen ved en Sammensmeltning af de 2 inderste Enditer.

2det Fodpar (Fig. (1) el fuldkommen normalt bygget, men skiller sig dog red en noiere Undersogelse fira samme hos Hummen red den nrstsidste Endits Bevæbning (se Fig. 9 a). Foruden de sædranlige Borster findes der nemlig langs den indre kant af denne Endit en Rrkke at eiendommelige. Enden tverlelte Torne, der sucessirt tiltager i Langde mod Spidsen. Den yderste af disse Turne (Fig. 9, b) har foruden de 2 Endespidser $\mathrm{i}$ den indre Kant 4 korte smaatænder.

De folgende i Par stemmer $\mathrm{i}$ alt ræsentligt
The limbs belonging to the anterior section of the body exhibit scarcely any essential difference to those in the female, althongh the first pair of antennæ are perhaps rather larger and more abundantly provided with olfactory papillæ. On the other hand, several characteristic peculiarities may be noticed in the iimbs belonging to the posterior section; or the branchial legs. In the first plare their number is invariably smaller, namely, only 10 pairs in all; and in the second place, the 1st pair is very unlike that in the female, being converted into a pair of exceedingly porrerful prehensile organs, by means of which the male, during copulation, grasps the shell of the female (see Pl. XX, fig. 15). Fig. 7 represents one leg of this pair seen from the front, and fig. 8 , the outer part of the same, magnified rather more highly. As will be seen, the exopodite, the epipodite, and the coxal lobes are nearly of the same appearance as in the female. The terminal section of the endoporlite, on the other hand, is rery greatly modified and conrerted into a hand, movably ronnected with the proximal part, the endites belonging to this section also being peeuliarly transformed. The hand itself is almost quadratic in shape, with the imner edge, or palm. much arched and armed with a row of 9 rery strong, somewhat lamellar spines, between which project stiff bristles. The outermost endite is transformed into a powerful, falciform, inward-curving claw, which issues with a somewhat expanded base from the end of the hand, and can, by the aid of certain muscles, be bent in towards the abovementioned spines. At the root of this claw, issues another appendage, which is also nsually bent inwards, but ends in a blunt point clothed with long bristles, and seems to represent the penmltimate transformed endite. Farther in between the claw and the above-mentioned spines, there is attacherl ret another appendage, which points straight downwards, and is in the shape of an oval lamina, closely set with bristles. This lamina seems to represent the antepenultimate endite. From the proximal part of the endopodite there runs inwards a single, broad, lamellar expansion elged with a double row of long bristles, and probably produced by a coalescence of the two innermost endites.

The 2nd prair of legs (fig. 9) is quite normal in structure, but on a closer examination, is distinguished from that of the female by the erpuipment of the penultimate endite (see fig. 9 a). In addition to the usual bristles, there is also, along the immer edge of this endite, a row of peculiar bifid spines, which successively increase in length towards the point. The ontermost of these spines (fig. 9, b) has, in addition to the two terminal points, 4 short denticles on the inner margin.

The succeeding 6 pairs agree in all essential 
overeus med samme hos Humnen. 9de og 10de Par mangler derimod ganske den paa disse Par hos Humen forekommende strengformige dorsale Lap af Exoproliten, hrorimod de ganske synes at stemme orerens i By'ning med 11te og 12te Par hos Humen.

Farven er hos begge Kijon i levente Tilstand neget mork, olivengron. Dette skyldes imidlertid resentligt ret i skallen indesluttede Dyr. Skallen selv el derimod temmelig grjennemsigtig og af lys lorngul Couleur, med km et svagt grouligt sikjær.

\section{Indre 0rganer.}

Den indre Organisation stemmer $i$ sine væsentligste Trak overens med samme hos Limmadia. Dog vil man verl en noiere sammenligning finde visse rharacteristiske Eientommeligheder.

Tarmen (se Tah. XLX, Fig. 1, Tal. IX, Fig. 6) strækker sig som et temmelig jernt tykt Ror ignennem Axen af Legenet og ender bagtil med en kort, muskulos Endetarm, der udmunder mellem Halens Endeflige. Fortil er Tarmen noget nedadlinmmet jOrerensstemmelse med Legemets Boining paa dette Sted og forbinder sig ventralt med det temmelig korte, fortil tra Mundaabningen lobende Spiseror. Dette sidste viser ved sin Forbiudelse med Tarmen en lignende klapformig Indretning som hos Limnadia (se Tab. XX, Fig. 4, oes). I Forbindelse med Tarmens forreste Del staar, som hos Limadia, et af 2 svmetriske Halvdele bestanende compliceret leveragtigt Organ (Fig. 11, $7 x$ ); men dette Organ er her kun indskrænket til den ventrale Del af Hoverlet og udfylder Storsteparten af Rostrums Hule. Hver Halvdel bestaar af talrige bugtede Blindsakke, der samler sig oventil til en enkel forholdsvis meget rummelig Udforselsgang (co), ndmundende i Tarmen med en vid Aabning (se ogsaa Tah. XVIII, Fig. 4 og 5).

Hjertet (Tab. XIS, Fig. 1, h, Fig. 10) har en lignende Beliggenhed som hos Limmatia og viser ogsaa en lignende Structur. Det er imidlertid forholdsvis kortere, idet det kun streklier sig lidt ind i 3lie fodbærende segment, og har kun ; Par laterale Spaltaabninger, medens 4 saadanue er tilstede hos Limmartia.

Nervesystemet. - Hjernegangliet (spe Tab. XIX, Fig. 11, 13, 1t) ligger delvis skjult mellem Leverens Udforselsgange, og viser idethele en lignende Bygning som los Limnadia. Dog er Synswervene (o],t) her betydelig kortere og deres kolleformigt opswulmede Ender er adskilte verl et tydeligt Mellenum (se Fig. 13). De Fortsatser, hvorfra Nerverne for 1,ste Par Folere udgaar $\left(\mathrm{a}^{3}\right)$ er stærkt forlængede points witl the corresponding legs in the female. The 9th and 10th pains, on the other hand, are altogether without the cond-like dorsal lobe of the exopodite found in those pairs in the female. while they appear to agree in strurture with the 11 th and 12 th pairs in the female.

The rolour in both sexes in the living condition, is a very dark olive-green. This, however, is mincipally due to the animal enclosed in the shell. The sliell itself is faily transualent, and of a light, hom yellow colour, with only a faint greenish tinge.

\section{Interual 0rons.}

The internal organisation agrees in its essential featmes with that in Limmadia, although certain characteristic peculiarities are to be found on closer comparison.

The intestine (see 1'1. XI, fig. 1; Pl. XX, fig. 6) extends, in the slape of a tolerably even, thick tube, through the axis of the body, ending posteriorly in a slout, muscular rectum, which opens ont between the terminal lobes of the tail. Anteriorly, the intestine is somewhat downmard-onred in accordance with the eure of the body at that place, and is connected ventrally with the rather short osophagns lunning forrards from the oral aperture. The resophagns, in its crmection with the intestine, exhibits a valre-like montrivance similar to that in Limmadia (se Pl. NIX, fig. 4, oes). Communiating with the foremost part of the intestine, as in $\mathrm{Lim}$ nadia, there is a complicated, liver-like organ, consisting of 2 symmetrical halves (fig. $11,7 n)$; but this organ is here confined to the ventral part of the head, and ocmpies the greater part of the avity of the rostrum. Each half consists of numeroni curved crea, which meet above in a single, comparatively very capacious excretory durt (co), opening by a wide nouth into the intestine (see also Pl. XVIII, tigs. 4 and 5).

The heart (Pl. XIX, fig. 1, h, fig. 10) has a sitmation similar to that in Limmortio, and also exhibits a similar structure. It is howerer comparatively slorter, as it only extends a little way into the Bril pedigerons segment, and has only 3 pairs of lateral ostia, whereas in Limmatir there are 4.

The Nervous System. - The cerebral ganglion (see Pl. I 1 , figs. 11, 13, 14) lies partly hidden hetween the excretory "Incts of the liver, and exhibits on the whole a similar structure to that in Limnadia. The optic nelres (opt), however, are considerably shorter here, and their clnt-like swollen ends are separated ly a distinct space (see tig. 13). The projections from which issue the nerres for the 
og skraat bagudrettede. Nerverne for Aareme (a ${ }^{2}$ ) udspringer ogsaa her fra de fra Hjernegangliet bagnd gaaende Commissurer. Buggangliekjaden (Tab. XX. Fig. 1,1) ligner samme hos Limmatia. dog med den Forskjel, at Tervestammerne er forholdsvis strelkere og ligger noget nærmelp sammen. Autallet af gangliose Opsrulmninger er selvfolgelig, i Overensstemmelst med det langt ringere Antal Fodpar, mindre and hos Limmadia.

Ovarierne (se Tab. XIX, Fig. 1) el af luetrdelig Storrelse, strakkende sig til hver Side af Tarmen rjemnem hele 'Truncus. De viser et stærkt lappet Udsemde, idet Egfolliklerne grupperer sig drueklaseformigt onking Orarialnolene (se Tab. XX, Fig. 13). Eglederen udgar fra den bagerste Del af livert Cvarimm og stmes at udmmde umiddelbart moler de ovenumtalte trefligede dorsale Blarle. Paa dette Sted ser man nemlig ofte storre Masser af modne Eg samlede. Som hos Limmatia. indeholder hver Egfollikel + Celler, hroraf alene den terminale bliver til det egentlige $\mathrm{Kg}$, medens de 3 orrige forestiller Nipringsceller og derfor tilsidst ganske absorberes (se Fig. 14-17). De af Orarierme udkonne Eg grupjerer sig sammen til 2 rundagtige kageformige Masser, der bæres mder s'kallen helt bagtil ise Tab. XVIII, Fig. 1 og ?). Hrer Egmasse indeholder et stort Antal at $\mathrm{Eg}$, der ved et klæbrigt Stof er heftede sammen. Eggene er omgirne af en simpel, ikke meget fast Kapsel, nden nogen ioinetaldende Skulptur.

Testes (se Tab. XI, Fig. 6) har samme Beliggenherl som Orariene og higner disse ganske hrad Anordningen af Folliklene angar (se Fig. 12). Disse sidste er inidlertil her alle af nogenlumde ens Storrelse og af noget nregelmæsig Form, samt indeholder hrer en med den centrale Kanal i Forhindelse stanente Hule, i hvis Tagge de neget smaa celleagtige Sadelenenter udvikle sig. Mundingen for vasa deferentia symes at ligge omtrent laa samme Sted som Mundingen for Eglederne hos Hummen.

Udvikling. - Jeg har desvarre ikke sely havt Anledning til at studere deme Phrllopodes Litrikling. Men ifolge Grubes Undersogelser synes den i flere rresentlige Punkter at skille sig fra den hos andre Phyllopoder. Larven har et meget eiendommeligt Udseende, som noget minder om samme hos Cimpedierne. Selv i det tidligste af Grube observerede Stadium, som ifolge Lemmernes Beskaffenhed ubetinget er et Namplins-Stadium, er nemlig Legemet drekket orentil af et meget stort fladt Prgskjold, og har nedentil et linnende men mindre Skjold, der forestiller Orerlæben. Hovedet har en meget eiendommelig Form, idet det gar ud i 3 horstormigt 1st pair of antennæ (a "), are very much elongated, and directed obliquely barkwarls. The nerves for the oars $\left(\mathrm{a}^{2}\right.$ ) also originate here, starting from the commissures which run hackwards from the cerebral ganglion. The ventral ganglion chain (Pl. XX, fig. 19) resembles that in Limmartia. though with the difference that the nerve stems are comparatively stronger, and lie rather nearer together. The nmmlier of ganglionic dilatations is, of course, in accurdance with the far smaller number of legs, less than in Limnatia.

The ovaries (see Pl. MIX, fig. 1) are of considerable size, extending thromgh the whole trunk on each side of the intestine. They present a verr meh lobed appearance, from the fact that the egofollicles are gromped botryoidally about the ovarial tubes (se Pl. XX, fig 13). The oviduct issnes from the hind part of each ovary, and seems to open immediately below the before-mentioned tri-lobed dorsal lamella; for at that place large masses of mature egos are often seen accumulated. As in L $\mathrm{im}$ matia, each ego-follicle contains $t$ cells, of whirll the terminal one only becomes the true egg, the other 3 representing alimentary cells, and leing therefore at last quite absorbed (see figs. 14-17). The eggs that have issned from the oraries congregate into 2 romnd, cakelike masses, which are bone beneath the shell at the verv back (see Pl. XVIII, figs. 1 and 2). Each eggmass contains a large number of egos, which are fastened together by a glntinoms substance. The eggs are surrounded by a simple, not very firm capsule, withont any conspicurns soulpturing:

The testes (see Pl. XX, fig. 6) have the same position as the ovaries, and resemble them exactly as regards the arrangement of the follicles (see fig. 12). Here, howerer', the latter are all of about the same size, and of a somewliat irregular shape; each contains a cavity communicating with the central chamnel, and in whose walls the very small, cellular' seminal elements are dereloped. The opening of the rasa deferentia appears to lie at about the same place as the month of the ovidncts in the female.

Development. - I have unfortunately not had an oppritunity, personally, of studying the development of this Phyllopod; but, according to Grube's investigations, it seems, in several essential points, to differ from that of other Phyllopoda. The larra has a rery pemliar appearance, somewhat resembling that of Cimipedia. Even in the earliest stage observed by Grube, which, from the condition of the limbs, is mruestionably a namplins stage, the body is covered above by a rery large fiat cara. pace, and has a similar, but smaller shield below, which represents the labrum. The head has a rerr peculiar shape, for it projects in 3 cruciformly-placed 
stillede Fortsatser, hroraf den miclterste forestiller Rostrum.

\section{Forekomst on Leveris.}

Det eneste Sted her i Landet, hror deme Phyllopode hiltil er observeret, er i Ustfinmarken red Matjok, en Biflod til Tana, hror Prof. Collett fandt den i Sommeren 188.. Da jeg nogle Aar senere, i 1S68, bereiste Finmarken, undlod jeg ikke at besoge demne Lokalitet, og rar ogsaa saa heldig at finde den her i Slutningen af Angust meget alnindeligt i en grund, med talrige Vandplanter bevoxet Groft. Alle Exemplarer var da fuldt udviklede og syntes at have opnaaet sit Maximum af Storrelse. Skjondt jeg noie undersugte alle Damme og Grofter i Omegnen, var det mig dog iklke muligt at finde noget Spor af den andetsteds end netop i den omtalte Groft, der saaledes maa have frembudt særlig gunstige Forhold til dette Dyrs Trivsel. I Lobet af nogle faa Dage indsamlerdes her et betydeligt Antal Exemplarer, ligesom Observationer anstilledes over det levende Dyr i mine Excursionsglasse. Dyrets Berngelser er temmelig kloclsede og lidet ndhol. dende, bestaaende $i$ et noget ujevnt og ligesom rullende Lob giennem Vandet, hvoruniler snart Ryg, snart Bug vendes opad. Under Bevergelsen ex Hovedet helt fremstrakt af Skallen, saa at Aareme fuldt kan virke, og Valvleme er herunder vidt aabne nedentil. Jeg kunde ikke observere, at Dyret nogensinde, som Tilfreldet ex med Limadia, frestede sig til de i Vandet værende Gjenstande. Naar Beragelsen ophorte, sank Drret hurtigt til Bunden, og la her ofte i langere Tid nbevæegeligt naa Siden, for saa igjen at foretage en kort Ulflugt i Vandet. Hammer og Humer forekom nasten i samme Antal og saaes ofte i Copulation, hrormder Hannen merl sine Gribefodiler med stor Kiratt omfatter Kanterne af Hunnens Valvler nedentil. Selve Parringsakten fik jeg dog ikke observere. At domme efter Kindbakkemes Bevæbuing, synes Dyrets Næring at være mere animalsk end Tilfældet er med de ovrige bivalve Phyllopoder, og bestaar rimeligvis for en stor Del af mindre Entomostraceer

Udbredning. - Deme Phylloporle blev forst opdaget af 0. F. Nüller i Damme nær Kjobenhavm, og er ogsaa senere her gjenfunden. Foruden i Danmark er den observeret ved Danzig af Lièvin, ved Dorpat af Grube, i Lillerusland verl Charkow og i Ungam ved Pest, endelig ogsaa i Silirien. 1 sin Udbrerning synes den saaledes ilethele, i Morksetning til Limmadia, at være en ostlig Form, og det er aabenbart ad den Vei, nordenom den botniske Bugt, at den har ulbredt sig til vort Land. processes, the middle one of which represents the rostrum.

\section{Occurrence and Habits.}

The only place in this country (Norway) where this Phyllopod has hitherto heen observerl is in East Finmark, near the Matsjok, a tributary of the Tana, where Prof. Collett foum it in the summer of 1895. When some years later, in 1888 , I travelled throngh Finmark, I did not fail to visit this loreality, and had also the goul fortune to find it there at the end of August, very plentiful, in a shallow ditch where numerous annatic plants grew. All the specimens were then fully developed, and seemed to have attained their maxinum size. Although I care fully examined all the ponds and ditches in the neighbourhood, I did not succeed in discovering any trace of it anywhere except in the said ditch, which must thus have offered ronditions especially favorable to this animal's well-being. In the course if a few days, a consileralile number of specimens were collected here, and observations marle of the living animal by watehing them in my collectingjars. The animal's movements are rather awkward, and not very persevering, consisting in a somewhat uneven and, as it were, rolling course through the water, sometimes with the dorsal, sometimes with the rentral side uppermost. During the morement the head is stretehed right ont of the shell, so that the oars can have their full effect, the valves meanwhile being wile open helow. I never observed the animal attaching itself to objects in the water, as is the case with Limmadia. When the motion ceaserl, it sank yuickly to the hottom, and often lay there a long time on its side, mutionless, then again making a short exenrsion through the water. Males and females are found in almost equal numbers; and are often seen in copulation, during which the male, with its prehensile legs, embraces with great power the lower erges of the female's valves. The act of copulation itself, howerer, I have not witnessed. Tudging from the armature of the mandibles, the animal's food appears to be more animal than is the case with the other bi-valve Phvilopola, and probably consists to a great extent of smaller Entomostraca.

Distribution. - This Phyllopod was first diseo vered by O. F. Müller, in ponds near Copenhagen, and has also been found there again subserquently. Besides in Denmark, it has leeen observed by Lièvin at Danzig, by Grube at Dorpat, at Charkow in Little Russia, at Pesth in Hungary, and lastly in Siberia, It therefore appears, in opposition to Limnadia, to be, in its distribution, an eastern form, and it is evidently by way of the north of the Gulf of Bothnia, that it has sprearl to our land (Norway). 



\section{FORKLARING AF PLANCHERNE.}

Tal. I.

\section{Nelualia bipes Fabr.)}

Fig. 1. Egharende I]un, sect fra renstre Nicle.

2. Namme sinet orentra.

3. Sleegtsmonlen lIan, reet tra hoire sile.

Nebatir typhlops, G. O. Sars.

Fig. t. Egharemle Jlun, sect fra hoire side.

\section{Tab. II.}

\section{Nebalia bipes (Fal)r.)}

Fig. 1. Storsteparten af Legenet af en ung, endun ikke skegtsmorlen Han, sect fra venstre Sirle. Tenstre Halydel at liycekjolitet er borttaget, for at vice de underliggeme thele. - ms Insertionen for skallens Lnkkemuske ; $r$ Pandeplarlen; $O$ Oinene; $a^{1}$ 1ste Par Folere; $a$ 2tlet Par Folere; $M$ lindlukkerne; $M_{p}$ Mandibularialue; $m^{2}$ 1ste l'ar Kjever; $m^{2}$ alet Par Kјеerer.

2. l'amleplalen sect orenfra, sterkere torsturret.

3. Oinene med dot tilhorende segment, seet ovenfra.

4. Vonstre (lie seet fra sillen.

5. En af Iste I'ar Folere hos Hummen.

6. En af 2let Par Folere lo.

7. Forenten af Legemet med Hundregionen, sect nedenfra. Af Folerne "r blot Basaldelen tegnet. $-r$ Pande llalen; $O$ Gincne; $a^{1}$ 1ste Par Folere; $a^{2}$ 2det Pas

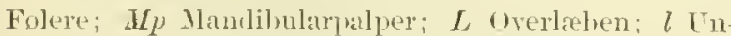
rerleben; $m^{1}$ 1:te Par Kjever; $m^{2}$ 2let Par Kjever.

8. Uverlelien stierkere forstoret,

9. [ntlexlaten

10. Kindlakkeme med sine Palper, secte fortra.

11. Tyggetelen af en Kindbakke.

12. Endeledidet af en Mandibulapalpe.

\section{Tab. III.}

\section{Nelualia bipes (Falrr.) 우}

Fig. 1. En Kjare af tste Par; p Palpe.

$1 \mathrm{a} . \mathrm{Ln}$ af Tornene pa Tygelappen, strertit forstorret.

2. En Kijeve af 2let l’ar; $p$ Endognatli ex Exognath.

\section{EXPLANATION OF THE PLATES.}

Plate I.

Nebalia bipes Fabr.)

Fig. 1. Grigrous female, soen from the left sirk.

2. Same, secull from alove.

3. Fexually mature male, seen from tho right.

\section{Nebatice typhlops, (4. O. sars.}

Fig. 4. (Iviguron female, seen from the right.

\section{Plate II.}

Nebalia bipes (Fabr.)

Fig. 1. Greatre part of the bouly of a young, not yet sexu. ally mature male, seen from the loft. The left half of the carapiac is remover to show the parts beneath. - ms, insertion of the arlinctor musele of the sleell; $v$, fromtal lamina; $O$, eyes; $a^{1}$, first pair of antenna; $a^{2}$, recond pair of antemuse; $\boldsymbol{I}$, mandibles; $M_{p}$, manclibular palpis: $m^{2}$, 1 st pair of maxille; $m^{2}$, 2nd pair of maxillit.

Fig. 2. Frontal lanina, seen firm alove, more lighly mag. nifierl.

3. Eyes, with the segment appertaining to them.

4. Left cye, seen from the sirle.

5. One of the list pair of antemse in the female.

6. One of the and - - - - -

7. Anterior end of the borly with the oral region, sem from belur. Only the liasal part of the antenne is drawn. $-r$, frontal lamina; $O$, eyes; $a^{1}$, first pair of antennat; $a^{2}, 2 n k$ pair of antenne; $\boldsymbol{M p}$, mandibular palpi ; $L$, labrun; $l$, josterior lip; $m^{2}$, lst pair of maxillar; $m^{2}$, 2nd pair of maxille?.

8. Lalnum, more highly magnifies.

9. Postricior lip.

10. Mandihles with their palpi, seen from the tront.

11. Nasticatory part of a mandible

12. Trminal joint of a mamdibuar gaip.

Plate III.

Nebalia bipes (Fahr.) of

Fig. 1. 1 maxilla of thu 1st pair; $p, p a l p$.

s 1 a. One of the spines on the masticatory lobe, highly mannitied.

2. I maxilla of the end pair; $p$, endognatlı; ex, exognatl. 
Fitr. 3. Fin Tiranelialfoul af lott. Parr.

4. Fin Branchialtorl af ste Par; $p$ lindepodit; $e x$ Fxo forlit; cp Epipulit.

5. En Tramehialfrel af The Par.

6. En Branchalton af selo sjolste Par.

7. En srommeforl af 1 ste l'ar.

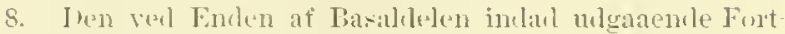
sils, starkere torstorret.

8 a. En af de terminale Ilacrer pail kamme, meget strerkt turstorret.

9. Hu srommetol af the Par; $x$ den indre Furtsats.

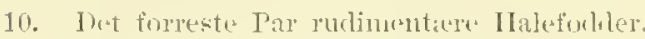

11. Dhe lagerste Par Haledemmer.

12. Sirkte Halesegment, mul venstre Halegren, set melenfra.

Tal. IV.

Nebatia bipes Falu: o

Fị. 1. En Foler at 1ste Par.

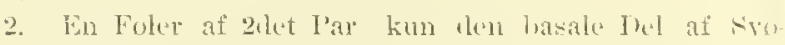
heten temuet.

3. En Kjove at 1ste Par.

4. En Kigere af slet Par.

5. En lirandialful at ste Par

6. En Llaletoul af 1ste Par.

i. En Halefexl at ellet Par.

8. Enden ai widste Halesegment merl renstro Halegren. sect neelentira.

\section{Netuatia typhlops, न. U. Sars. क}

Fig. 9. Then forreste led af Legemet seet tra hoire side: hoiere Halyart af Rrgekjuhlet burttaget.

10. I'ankleplaulen, seet orentra.

11. binene met det tillorende seognent, ovenfira seet.

12. V'ntre Kindbakke meil Palpe

13. En kisere af 1ste Par.

14. En Kjare af 2let Pau.

15. Ein Brunchialforl af 1ste I'ar.

16. En Branchialfol af silste l'ar.

17. En srommetent af Iste Par.

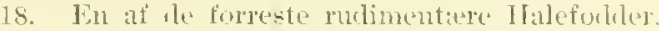

19. En af de hagerste Ilaildeforder

Tab. Y.

\section{Tebalia bipes Faln.}

Fig. 1. Skematisk Fiem at en llnn, seret fra hoire side, med

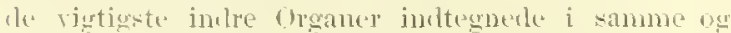
allgivne meet serskilte Farvere.

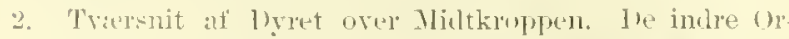
gane angine med samme laryer sm pala Fir. 1. or Rigskjolelet: i Tarmen: Cv, Cd Taruene Blimet-

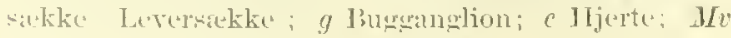

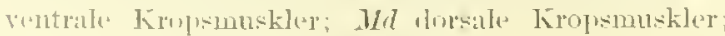

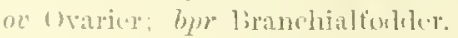

3. Tommons ("hitinskulut, secet frat remstres sile

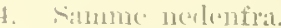

Eit strkik at Bugganglivkjacken.

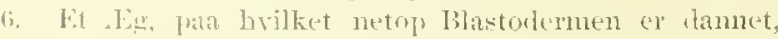

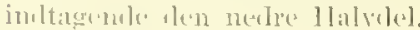

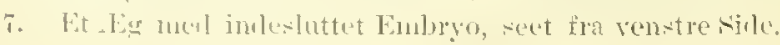

Fig. 3. A branchial leg of the 1st pair.

4. I hranchial leg of the sth vair; $p$, emroporlite; er exporlite; ep, epipmelite.

5. I branchial ley of the the pair.

6. I branchial lece of the sth last pair.

7. I natatery lege of the 1st pair.

8. The inwarrlpuinting projection at the end of the basal frat, now lighly magnified.

8 a. One of the terminal hooks on the same, very highly magnitierl.

$\therefore$ I natatory lex of the the pair; $x$, the inner pro jection.

10. The foremost pair of rullimentary eaudal legs.

11. The hiudmost pair of camblal limbs.

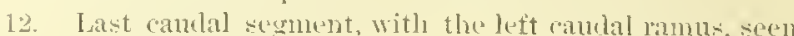
from below.

\section{Plate TY.}

\section{Nebatia bipes Fabr. o}

Fig. 1. An antemna of the 1st pair.

2. In antema of the ent pair only the hasal part of the flagellum slrawn.

3. I maxilla of the 1 st pair.

4. A maxilla of the 2 wl pair.

5. I branchial leg of the sthe pair.

I camlal leg of the 1 st pair.

1 courtal lege of the enul pair.

$\therefore$ End of the last caulal regnent with the left caudal ranums. seen from below.

\section{Nebalia typhlops, (i. O. Sars. \&}

Fig. 6. The formost part of the boly seen from the right right half of the carapace removed).

10. Frontal lamina, seren from ahore.

11. Eyes, with the sement belonging to them, secen imom abore.

12. Left manclilje with palp.

13. I maxilla of the 1st pair.

14. I maxilla of the 2 encl pair.

15. I lianchial leg of the 1st pair.

16. I loranchial leg of the last pair.

17. I natatory lege of the 1st prair.

18. One of the formost rulinentary caudal legs.

15. One of the limimost caudal leags.

\section{Plate T.}

\section{Neloalia bipes Fabr.}

Fig. 1. Dianrammatic trawing of a female, secen from the right, with the mest infortant organs shown in olifferent relonir.

2. Transerese section of the animal throngh the mesosome. The intermal wryas representerl in the same colours as in fig. 1. C, arapace; intestine; $C v, C l$, intertinal caea biliary cieca ; $g$, ventral ganglion; c. lutart: $M v$, rentral muxcles of the boly; $I d d$, worsal nuscles of the buly; or, waries; bpr, branchial legr.

3. Chitine skeleton of the intestine, seen from the lett.

t. The same, from loclows.

5. I piece of the ventral ganglion ehain.

6. In egg, in whith the blastexterm is just formed, and nempines the lower halt.

7. In egg, with enchusel vuluryo, seen trom the left, 


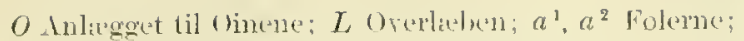

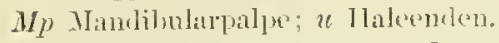

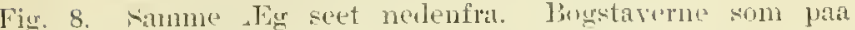
foreganurle Figur.

9. Lt bulıry, ungen Tiul efterat lighuden er afkastet, sont oventira. $O$ Oinene; $a^{3}$ Liste l'ar Folere; $a^{2}$ 2alet Pin Folew; brp Anlieg til Branchialfodiler; $p l$ Anlieg til srommeforker: u Ialeenden.

10. Funme Enbryo seet fria venstre side. I l'ande. platen; $L$ overlielnen; Mp Mamlimalarpalpe: $m^{2}, m^{2}$ de 2 Tar Kjever. 1) orrige lugataver som pala foregaaeusle Figur.

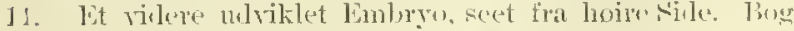
staverne som paa foreganemele Figur.

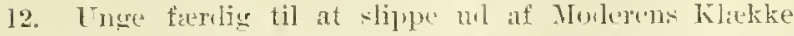
luke, seet fra boire sike. Ms Insertionsareaten for skallens Lukkemuskel; plx silste l'ar, rnulnu ikke ulviklerle srommoforler; $c^{1}, c^{2}$ de 2 rudimentiele llalefoller. De ovige Bugstiver som paa de 2 fore. gatenti. Figurer.

\section{Tab. VI.}

\section{Branchinecta paludosa Müller.}

Fị. 1. Fulnt mitriklet Han, seet netenfrì

2. Solume fra venstre sile.

3. Euberemle Hun, seet fra hoim fint.

4. Silmme orenfra seet.

5. larre i sidste stadinm, seet tra venstre side.

6. Samme wenfra seet.

7. Jovedet af en Unge i 1ste postlarvale stalimm, seet norlenfra. $O$ de sanmensatte bine; o det enkle bie; $a^{1}$ 1ste ['ar Folere; $a^{2}$ alet l'ar Folde; $L$ overleben: II Kindlakkerne.

8. Ln af 2ilet Par Folere af samme, strerkere forstorret.

9. lloreslet at en fullt udviklet llun, seet netenfra. $m^{2}, m^{2}$ le 2 Par Kjiever. De ovrige lugstarer som Jaa Fig. 7

10. Enden af Halen meil llalepladerne, seet ovenfra.

11. Genitalsegmenterne med den tilsturlemes Del af Folkroplen og thalen af en fulit wiviklet llan, seet fra renstre sille: c Hjerte; $t$ Testas; pribe Kjonsved hiprig.

12. Sierma ('eller vesl mescet sterk Forstorrelace.

\section{Tab. VII}

\section{Branchinecta paludosa Mïller.}

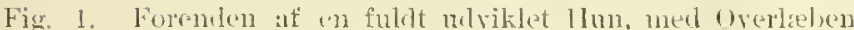
luftet oll fra Kindlukkerne, sect nulenfra. $O$ ile sammensate Oine; o let enkle Oie: $a^{\prime}$ lste l'ar Fo-

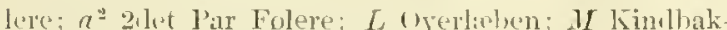

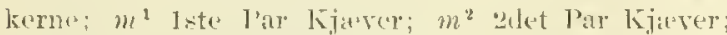
$p^{2}$ Lete Par Eranchialtisklex.

2. lloverlet af en Euldroxen llan, suet furfra. logrstaverne som phat foregaacmule figur.

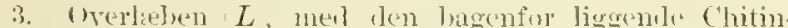

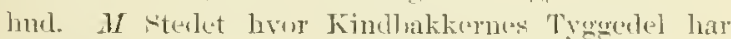
ligget; $m^{2}$ steclet, lwar lste l'ar lijever har varet fiestule.

4. lin kindibakk seet kurfit.

5. Sammes Tygueflade sterkt forstorret.

(j. En Kieve af 1ste Pal.
O, ayes in process of formation, $L$, labrum; $a^{2}, a^{2}$. antennar; $M p$, mandilmlin pralpi; $u$, and of the tail.

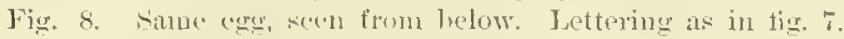

9. An cmbryts, sone time after the expeskin is ant, seen from alwori: $O$. eyes; $a^{1}$, lst pair uf antemnie: $a^{2}, 2 n d$ fitio of antenne: brp, rudimente of branchial lows; $p l$. rulimunts of natitory loge; $u$, chul of tail

10. Sane andryw, sexn froms the left. $R$, frontal lamina: $L$, lalmun: $M_{p}$, namlihular palpi; $m^{2}, m^{2}$, the 2 pair: ot mixilles. The rest of the lettering as in tig.

11. A mure developed embryo, seen from the right. Lettering ats in fige. 10.

12. Ioung one ready to "merese from the mother's inculat tory casity, sem from the right. Wrs, area of inser. tim of the alductur muscle of the shell; $p l x$, last pair of the not ret developed natatory leas: $c^{2}, c^{2}$. the 2 rulinentary cantal lege. The rest of the li.t tering as in the 2 preweting figures.

\section{Plate VI.}

\section{Branchinccte paludosa, Iïiller.}

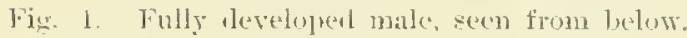

2. Sime, from the lint.

3. Origerons finule, sen form the right.

4. Same, sexn froms alore.

5. Larva in the list stage, seen from the lett

6. Samo, secen trom alboves

7 Hearl of a young one in the 1st prost.larval stage, seen from lyelow. $O$, componml reve; 0 , ocollus; $a^{2}, 1 \mathrm{st}$

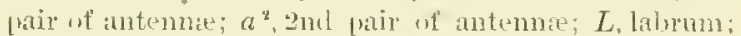
11. num libles.

8 one of the 2 nul pair ut antenute of the same, more liicrbly matrilitiel

9. 1leat of a fullydereloped temale, seen from lyeluw $m^{2}$. $m^{2}$, the 2 lairs of maxillie. The rest of the let tering as in fig $i$.

10. End of the tail, with the candal lamelle, seen form aloove

11. Genital segments with the adjacent part of the an teriog part of the buly and the tail of a finlly-sleve loped male, sern from the lett. c, heart; $t$, testes $p$, cxtermal sexual apjumbanc.

12. जperm cells, very hioghly magnitiul.

\section{Plate VII}

\section{Branchinecta palurtosa (1)üllex.}

Fis 1. Anterior enc uf a fully-electopect female, with the labrum raisel from the manelibles, sexn from beliw.

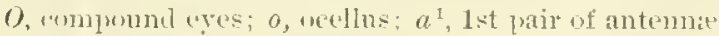

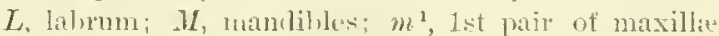
$m^{2}$. 2nu pair of maxille; $p^{1}$, 1st pair uf loranchial lexps.

2. Ilearl of a full-grown mals, seen from the front. Lettering as in tig. 1.

3. Talnum $L$, with the phitinons skin lving behinel it, $\mathcal{H}$, place where the masticatory part of the manij. bles has luse; $m$ !, place where the 1-t pair of max-

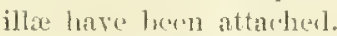

4. I nandible, sesen from the front.

5. Nlasticatery surtare of the same, highly magnifich.

6. I maxille of the list pair. 


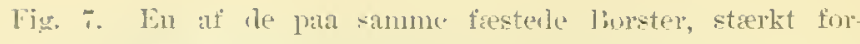
storret.

S. En Kjeve at eqlet Par.

9. En Branchialfud af iste Par hos llunnen; end Endspodit; ex Fxopolit; ep Epiporlit: 0 bisalplacle.

10. Et Stykke al hinterne af den inderste Endit med de: tilhorende lefonnigt krmmmene Borster, strerkere for storret.

11. In Branchiallod af 5te Par. Lingtarerne som paa Fig. 9.

12. Fn Branchialfocl af sidete l'ur.

13. En Brancilatfox af 5te l'ar hos llannen. Bogstaverne stm 1:ia Fig. 9, 11 og 12.

\section{Tab. VIII.}

\section{Branchinecta paludosa Niiller:}

Fig 1. Legenet at en Hun, nerl indlognet Nervessetem, seet fra Bugsiclen.

2. Eurlen af en Foler af 1-te l'ar, starkt forstoret.

3. En Lugtepapille fra sammu, indnu staerkere forsitsret.

4. Ifjernegangliet mol de fra sanme ulwingingende Nerver, sect ovenfra. o thet enkle hie; a sandsegruber i Horedets Integument; $a^{2}$ Basis af Iste Par Folere meal den tilswirende Norve; $O$ s.rnsnerverne; $a^{2}$ Xer. verne for 2rlet Palr Folere.

5. Et stykke af Bugenangliekjielnom.

6. Den vilre Del at et af le simmensatte Gine i Lengrkesnit.

7. 2 sirnselementer isolerede. d Nervefiber fra syns. nrenen; c synstav: $b$ krrstalkegle; $a$ lindsefomigt fortrkket Del at samme.

s. Sillegleten af et Halesegment, med 2 Thulnerver.

9. 1lul lapiller med Foleborster, sturkt forstoret.

10. Len forreste Ind at Tarmen med sine 2 Blindsakke, scet orenfiri.

11. Crenitalsegmentet af en IIun med Foheholderen og () varieme or , wet neilentra.

12. Et styke af Kitkjiertelen.

13. lit Eg med begrndend, Klorning

14. Fet andet, Eg uden Klurning.

15. Win Larve $\mathrm{i}$ et af de tibligere starlier, seet fra Bug siden.

16. Lin larve i et senere italium, seet fra liugsilen,

17. Furenden af Legemet lons et liblt senere larrestaliun, seset nedenfra. O ile sammensatte oine; o liet conkle (1iv: $a^{2}$ 1ste Par Folcre; $a^{2}$ 2rat Par Folere; $L$ Oror lithen; $M$ Kindlakkerne; $p$ Irandibularforderne; $m^{1}$, $m^{2}$ kjaverne.

\section{Tab. IX.}

\section{Polyartemia forcipata, Fischer.}

7in. 1. Fuldwaxen, anghende llum, seet fral hoire side.

2. Simme, seet orenfial.

3. Fuldroxim Han, seot nellenifia.

4. Somune fra venstre sisls.

5. Spisken af en af Gribeantennernes Grene, starkere iins:torret.

6. Jomlen af Ilalen med IIaleplarlepne, seet orenfra.

7. Fu larve i ut af de tinligure stitker, sect nedenfra.
Fig. i. Wne of the lristles attached to the same, highly magnified.

8. I maxilla of the 2nd pair.

4. I branchial logr of the lst pair in the temale; ent, endoprolite; $e x$, exuporlite; $e p$. epiporlite; $b$, has:al limella.

10. I piese of the edge of the innermost endite with its falciformly curved bristles, nore highly magnifix.

11. A branchial leg of the 5th pair. Lettering as in fig 9 .

12. I branchial jeg of the last pair.

13. A branehial leg of the sth pair in the male. leettering as in figs. 9. 11 and 12.

\section{Plate VIII.}

Branchinecta patudosa Müller.

Fia. 1. Buly of a female with the nervous system drawn in, seeen firom the rentral side.

2. Extremity of one of the 1st pair of antennse, linghly maunitied.

3. An olfactory papilla on the same, still more highly mannificel.

1 (erebral gandion with the nerves issuing from it, seen from alove. $o$, owelhus: $a \Omega$, senswry jits in the integument of the beal; $a$, base of the first pair of antenne, with the corresponding nerver; $O$, optic nerves: $a^{2}$, nerves for the $2 m$ p pair of antemas.

5 A piece of the rentral sunglion chain.

6. The weter part of ome uf the compoum ares in longiturlinal sucction.

7. Two risual elements isolatex. d, nerve fibres from the optic nerve; $c$ optic rorl; $b$, errstatline cone; a. lenticularly thickened part of the same.

s. Lateral part of a tail segment, with 2 cuticular merves.

9. ("utaneous papillit, with sensenry l,ristles, highly mag. nitierl.

10. The anterior part of the intestine with its 2 esera, secen from above.

11 The wenital segnent if a female with marsupium and oraries ov, seen from betow.

12. I piese of the glutinous glant.

13. In egog with deavage commencerl.

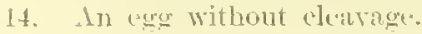

tj I larva in one of the earlier stages, seen from the vintral silke.

16. A larvil in a later stiun, seen from the rentral sirle.

17. Anterior end of the lumly in a rather more allyanced larval stage, seen from bolow. O. compound eyes; o, wetlus; $a^{1}$, 1st pair uf antemne; $a^{2}, 2$ nd pair of antenne; $L$, lalurum; $\boldsymbol{M}$, mamlibles; $p$, mandilutar less: $m^{1}, m^{2}$, maxillits

\section{Plate IX.}

\section{Polyartemia forcipata Fischer.}

Fig. 1. Full-gruwn, ovigeruns fomale, seen from the right.

2. sime, seen from alowis.

3. Ful]-gxown male, seen from bxhn

4. Sime, from the left.

5. Print of one of the rami of the prebensite antema, more highly magnifiet.

fj. Fin uf tail, with the randal lancllse, seen from above.

7. I larra in one of the earlier stages, seen from below. 
Tab. X.

Polynrtcmia forcipata, Fisclus.

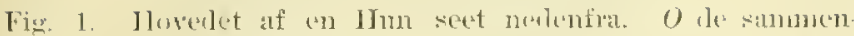
sitte Ujue; o det enkle bis: $a^{\prime}$ lsto l'an lisulere;

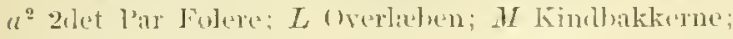
$m^{2}, m^{2}$ Kjoperne.

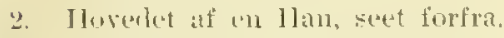

3. Fin Fuler at 1ste Par.

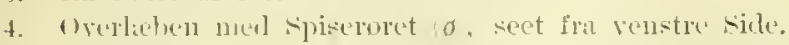

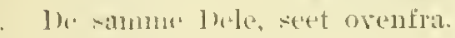

6. Hin linslbalke, seet fortira.

7. lin Kjare al 1 ste Y'ar.

8. Lin Kjere at 2let l'ar-

9. En Baranchalfor at 1ste Par.

10. Jin Branchialforl af 11 te Par.

11. Fin Branchialfixl af siclete I'ar.

12. 1)(n hagm Ind af regemet af "n fultroxen Hun,

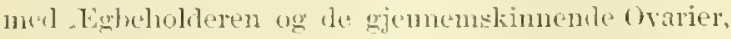
secet fra hoire sirle.

13. Crarierue med Fitkjertelen, sest wentra. ov Orarialtulerne; ovd Egleilerne; gl Kilkjertelen.

14. lit af owarieme med len tilsvarencle Eggleder, isolered og reet fin sillen.

15. Bit mumlent F, stemkt forstorret.

16. 1) bagre Del af Legrmut, ulen IJaleplaterne, af en fuldroxen IJan, seet fra ronstrot sicle. $t$ Testes: ed vas heferens; p vilre kionswatheng.

\section{Tab. XI}

\section{Lepidurus glacialis (Kroyer.}

Fig. 1. Fuldroxen Ilun, wrenfra reet.

1 a. Samme i maturlig storrelse.

2. Samme serel nodenfra, i samme Forstormese som Fig. 1.

3. Samme seet fra venstre sille, med Kroluren stierkt foroverholet.

4. En litrie, sect urentra.

5. Lin anden Larve $i$ et noget sinere stadium, seet orenfiri.

6. Fuldruxen Han, ovenfra sest.

6a. Somme i naturlig storrelse.

\section{Tab. XII.}

\section{Lepiduns glacialis kroyer.)}

Fig. 1. Foremlen af legenet, secet neulenfra. $a^{1}$ 1sta Par Folere; $a^{2}$ 2lat Par Folere; I Overleden (oploftet

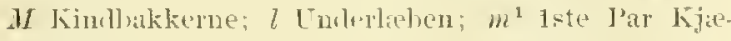
ver: $m^{2} 2_{1}$ let Par Kijerer: $p^{2}$ 1ste Jorluar.

2. Eu Foler af 1ste I'a1:

3. Jit styke af Enderlelens nexler kant med de paa. siddende. Lugtepajillew, strerkere forstorwt.

4. En Lugtepapille, meget strerkt forstormet.

5. Fin Folex af 2let Prer.

6,7. Fanme Fold af 2 andre Fxemplarer, for al vise Va riationerne: i Form og itorrelse.

8. Fin limibakk", secot fortm.

9. Jin inderste Tand af samme, starkt forstomet.

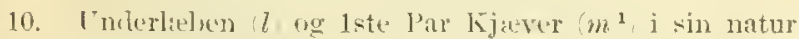
lige Forbindelse nerl hinaden, tilligement spiseroret be, wect logira.
Plate X.

Tolyartemia forcipata, Fischer:

Fig. 1. Ileal of a fimale, sen from below: O, mompound eyes; 0 , ofellus; $a^{1}, 1$ st pair of antenne; $a^{2}$, 2ul pair of antennu; $L$, labrum; $M$, manlibles; $m^{1}, m^{2}$. maxillat.

2. Ileal of a male, secen from the front.

3. One of the 1st pair of antenue.

4. Lahrun, with insophayus $\sigma$, seen trom the left.

5. Siunc parts, suen from abuve.

6. A mandihle, sern from the fromt.

7. Cone of the list pair of maxillet.

8 me of the 2 url pair of maxillic.

9 (me of the 1:1 pair of branchial legs.

10. ()ne of the 11 th par of branchial legs.

11. (me of the lant jair of loranchial lews.

12. Josterior fart of borly of a full-grown fenale, with marsupinm, and the ovaries slining through, seren from the rient.

13. Gvaries with the glutinous glanc, seen from alwore.

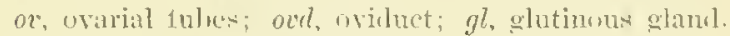

14. One of the ovaries with its corresponding oriduct, isolaterl, and seen from the side.

55. A mature crum, highly magnifierl.

16. Posterior part of the bouly, withont candal lamellex, of a full-grown male, seen from the left. $t$. testes; $v d$, ras deferens; $p$, external sexual aprenlagu.

\section{Plate XI}

\section{Lepidums glacialis líroyer.}

Fig. 1. Full-grown female, secen from albovet.

1 a. Fame, natural :iza.

2. Same, seren from lesow, magnified with the same Jwher ats figr. 1.

3. Came, sem from the left, with the body lent very mucle formarts

4. A larra, жеen from ahuse.

5. A larva in at rather more advanced stage, seen fron alove.

6. Full-grown male, reen from aluse.

(j). Same, nutural siza.

\section{Plate XII.}

\section{Lepidurus glacialis wrover.}

Fig. 1. Anterior chel of bouly, seen from beluw. $a^{2}$, lot pair of antenuse; $a^{2}, 2$ nd pair uf antenne; $L$, lillnom raicel : $M$, mandibles; $l$, posterior lip; $m^{2}$, 1st pair of maxillie; $m^{2}, 2 n$ ] pair of maxilla; $p^{2}$, 1st pair of legx.

2. An antenna of the list pair.

3. I piece of the luwer culge of the terminal part, with its olfartory japille, more highly magnifiesl.

4. An olfactory papilla, very moch magnifict.

5. An antemna if the seconil pair.

6, 7. Same antenna in "2 other specimens, to show the variation in form ane sime.

8. A manclitile seen from the front.

9. The innermost denticle of the same, higluly mag nitiert.

10. Posterior lip, 7 and 1 st pair of maxillse $\left(m^{2}\right.$ in their natural connection with one another, and exophagus toe, seen trom hethind. 
Fis. 11. ['mlertathen mel spristruset, seet fortia.

12. En Fipere af 1ste l'ar.

13. lin Kjece af 2tlet I'ar: $p$ Palje.

14. In Forl at 1ste I'ar. m C'oxallapunu; 1-5 Ensliterne; ex Exopodit.

15. En Forl af 2dut l'ar. Fingstaverne som paa foregaaende Figur.

16. In Forl af 10ile l'ar.

17. En Fod af lite I'ar. ov Kigkapseden med et indesluttet $\mathrm{T} \mathrm{s}$.

18. En For af 12 te l'ar.

19. En Forl af et af de lagerste Par verl samme Forstorretse.

20. Samme Ful lwtylelig stierkere forstoret.

21. En Forl al sillste l'ar; sommm Furstorrelse som Fig. 19

22. Sammu Fud sterkt forstorret. Bogstaverne som par de feregaaemere Fignrer.

23. Than bagre lol af Legemet mat Hateplarlen ng Basis af llaketranden", seet orention.

24. Somme Del reut neclentra.

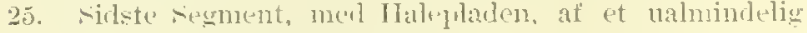
stort lixemular, seet wernfra.

26. Simme $\left[x^{2}\right.$ af 2 andre Exemplarer, for at rise Taria tionerne i Vlateplatens From.

\section{Tab. XIII.}

\section{Lepidumes glacintes, Froyer.}

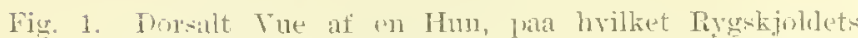
trie Del er bortaget, tor at visa de underliggende? Dele, sect orwerm. Verl langere Tists Indlegning i (rlycerin, or lagenut gjort ladst gjennem-igtigt, - aa at de indre oreaned delvis skimer igjemem, O de sammensatte Oine: oc det rnkle (1); $x$ Postocularknurlen; $M$ Kindlakkerne; $p^{1} 1$ ste Foulpar; $p^{11} 11$ te Forlyar merl Tokapslen: I Tammoret; $l$ Ieverem: 6 Hjertet; of Waricrme.

2. Latcralt vue af et andet Exemplar, paa hrilket rem stre Ilalvourt af Iivekjoldet er lyortaget. $a^{1}$ 1ste

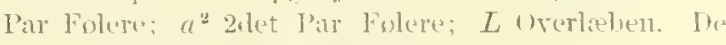
wrige Bugstater som pata Fig. 1

3. Fnctetliger af leveren, stirkt forstorget

4. Sikilkjiertelen.

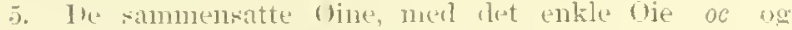
Hjernegangliet $y$, wrentira sext.

6. En kisytalkegle seet fira derl valre Eurle.

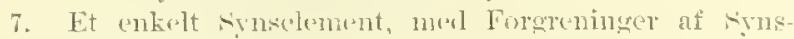
nerven reet Bisis.

8. Portorularkmulen.

9. Et Stykke af Bumgangliekjirlens forreste Del.

10. Et andet strkle liengire ladetil, simme Forstorrelsp

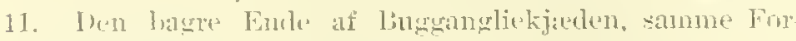
storevise.

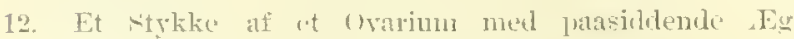
finlikiler.

13. To af be mintsto ligfollikler isterede.

14. To videre mlviklefle Firfollikler.

15. Fn enlnu mere udviklet Jufullikel.

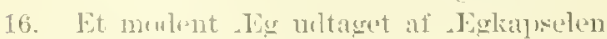

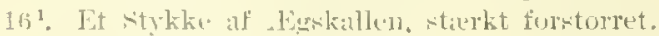

17. Ft stykke af un silulstuk.

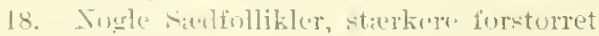

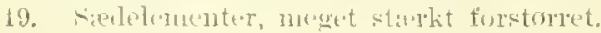

20. [in Fis] af 11 te lirr los llammen.
Fig. 11. Posterior lip and esophagus sen firom the font.

12. I maxilla of the 1st pair.

13. I maxilla of the 2 nal pair. p. paly.

14. I lecr of tlue 1st pair. m, ersal lobe; 1-5, andites; ex, exopralite; $e p$, epiporlite.

1.). I leg of the 2 ant pair. Lettring as in fig. 14.

16. I lear of the 10th pair.

17. I leg of the Ifth luir. $o x^{*}$, segeresule, comtaining an $\mathrm{e}^{\mathrm{g} g \mathrm{~g}}$.

18. A lear of the 12 th pair.

19. A leg of one of the himlmost pairs, nagniful with tho same power.

20. Fame leg, under a mueh higher maguification.

21. I leg of the last pair; maynitied with the same power as tig. 19.

22. Sance leg, highly magnified. Lettering as in the pre (eeling tiguress

23. l'osterior part of body with cauclal lanella and hase of rauclal filaments, sesen from almet

24- Same gart, seen trom belıw.

25. last sexment, with candal lamella if an musually

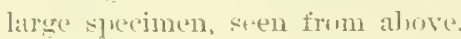

26. Sinfe part of 2 other specimens, to show variations: in the shape of the rautal lamella.

\section{Plate XIII}

\section{Lepidurus glacialis, kroyer.}

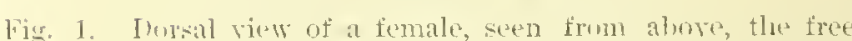
part of the carapace bring removel to show the larts fencatls. By being lept for some time in wy "rine, the bumly has heen renderesl semi-transparent, so that the internal uranes are partly visible thromgle.

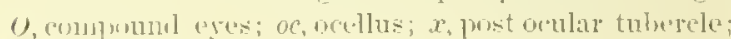

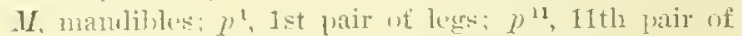

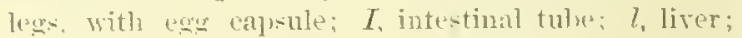
c. heart: ot, ovaries.

2. lateral view of another specinen from which the left loalf ut the earanace is remorecl. $a^{1}$, l-t prar of antemne; $a^{2}$, 2nol pair of antenne; $L$. lablum; the rest of the lettering as in fig. 1 .

3. Terninal lobes of the liver, highly mignifierl.

4. Thell ghant.

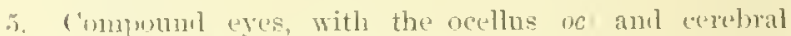
sanglion $y$, soen from ahore.

6. I crystalline come seen from the outer enst.

7. I sinere visual element, vith ramitications of the optic nerve at the base.

8. T'mstreular tulerele.

9. I'iexe of the foremost part of the ventral ganglion disin

10. Inether yiece, farther lack, sane magnitiontion.

11. The posterior end of the ventral gamplion chain, same nannitication.

12. I portion of the ovary with its eretollicles.

13. Two of the smallest eng-follioles isulaterl.

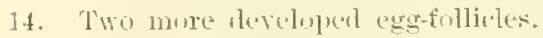

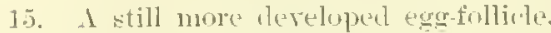

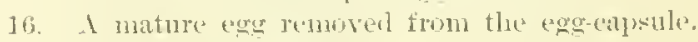

$16^{1}$. A piece of egg-shell, highly magnified.

17. A piece ot the testes.

18. some sperm-tollichs, more higlsly magnitienl.

19. Aferiu telumente, very much magnitied.

20. I lear of the 11 th prir in the male. 


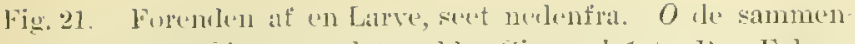
satte Gire; oc det enkle Gin: $a^{\mathrm{l}}$ 1)te l'ar Folere:

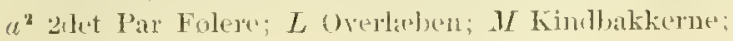

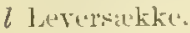

22. Jin Forl at 1ste Par af silnme farve

23. Jin Fenl at 2 led I'ar.

24. Jin Forl af 11te Par.

25. En at de bignentor liggenule Forliker.

26. En af he allerbagerste Foulder.

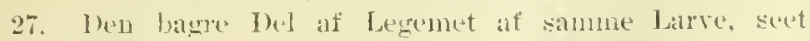
ovenfira.

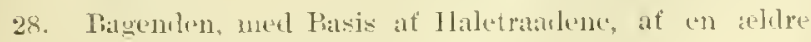
larve, wentrat sext.

\section{Tab. XIT}

\section{Limnadia lenticularis. Lin.}

Fig. 1. Fuldroxent, aegberende lixemplar, scet tha lovere side. 2. Simme oventra.

3. Simme nedentrat.

4. En kun lidt orex 1 mmo. lang L'nge, seet frol venstre ride.

5. Lin anden nuget storre Thoe, fra sinume wide.

(6. Et Exemplar, jaa hoilket den forste Viextrtribe har

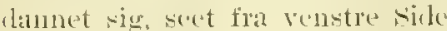

\section{Tab. XT}

\section{Limmarlia lenticularis. Lin.}

Fig. 1. buret liserende i sin naturlige situs i hoire talvel. Venstre Valvel burttaget.

2. Det forreste Afonit af Linemet seet fial renstre side sterkere forstoret. Aarerne ex burtagne. $r$ liost rum; af Fastheftningsorgun; $O$ de sammensatte Oine; oc det enkle Vie; $a^{1}$ 1ste Par Folere; $L$ orerletben; $M$ Kindlbakkerne; $m^{1}$ 1ste Par Kjever; $m^{2}$ 2ulet Par Kijerer; $i$ Tarmen; $l$ Leveren; ms Insertionsareaen for skallens Lukkenuskel; $c$ Forenulen af IJjertet.

3. Sinume Del, med liasis alt Aarerne, seet ovenfra. bigstaverne som par foregatende Figur.

4. Simme ] hel, uden darerne, seet nedentra. Jiogsta ferne som paa do 2 foregaremle figurer.

5. En Foler af 1:te Par.

(j. Fun at de pala samme teestedu. Lugtepapiller, stertst ferstorret.

7. Overlatyen seet fral venstre sicle.

8. En Kindhakke, sect forira.

9. En bed af den ventrale Jlarke, mimidlelbart bag Alund caloningen. $M$ sterlet, hvor Kindhakkernes Tygge Wele har ligget; $m^{1}$ late Par Kjerer; $m^{2}$ 2det l'ar Kjever; oes spiseroret.

10. En kijere af 1ste P'ar.

11. To at de par samme fiestede pigtirmige Borster, stierkt forstorret.

12. En Kinere af elet Har.

13. Nimme Kjeve stierkere forstorret.

\section{Tab. XVI}

\section{Limnadia Tenticularis, Lin.}

Fig. 1. En daure Foler af elet l'ar\%

2. Tre af de til Forsiden af den vodre Gren firstede l'inge, sticrkere furstomet.
Fig. 21. Anteriol enel of a larva, seen from below. $O$. conn

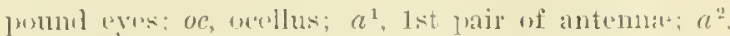
2n] pair of anteman'; L, labrum1; $M$, mandibles; $l$. biliary ereea.

22. I lexg whe the pair of the sama larva.

23. A leg of the 2 mil pair.

24. A leg of the 11 th pair.

25. One of the liegs farther batk.

26. One uf the hinelmost lexp.

27. Pusterior part of the same larsal, secen firmen aluse.

28. Posterior end of an whler larva, with the base of the comulal filanents, secen from alwore.

\section{Plate XIY}

\section{Limmadia lenticularis, Lin}

Fig. 1. Full-gruwn, wigerons specinuen, seen from the riglt

3. Same, trum alwe.

3. Sinse, tron lxduw

4. A young one, only a little (1)er 1 1mm. in length. soren from the left.

5. A somewhat larger voune one, from the left.

6. A suecinen in which the first line of growth has loeen formed, seen finm the left.

\section{Plate $\mathrm{XT}$.}

\section{Limnadia lenticularis, Lin}

Fig. 1. The animal, bying in it natural pesition in the riglit ralve: left valve renoverl.

2. The anterior part of the bouly, seen from the left, more lighly magnitierl. The oars are remeserl. $r$, mstrun; at, affixing organ; $O$. compound eres: $o c$, ocellus; $a^{\prime}$, Lst pair uf antennat; $L$, labrum; $M$. mandibles; $m^{1}$, lst par of maxille; $m^{2}$, 2nd pair of maxille: $i$. intestine: $l$, liver; $m s$, area of insertion of the thell's adeluctor muscele; c, anterior end of the heart.

3. Same laut, with the bare of the oars, sceen from alowe. Lettering as in fig. 2.

4. Same part, withont the osise, seen from bedus. Let tering as in figs. 2 and 3.

5. In antemna of the lat pilir.

6. One of the altactory bapille on the same, highly magnifierl.

7. Lahrum seen from the lett

8. A mandible, seen fromi the front.

9. Past of the rentral surfice, immediately behim the oral alerture. $1 \Gamma$, platee where the mastinating part of the mandibles has leecen; $m$ ', 1st pair of maxilla: $m^{2}, 2 n+1$ pair of maxille; oes, weophatigus.

10. I maxilla of the lst pait.

11. Two of the sliniform loristles un tle same, highly magnitied.

12. A nlaxilla of the 2nal pair.

13. Same maxilla more highly magnified.

\section{Plate XVI.}

\section{Limnadia Tenticularis, Lin}

Fig. 1. An war antemna of 2 al prair.

2. Three of the spines affixal to the front of the outer ramus, more highty magnifierl. 
Fin. 3. En Fod af 1ste Par; 1-5 Endupoliten med sine Enlited; ex Fxopoliten; $e x^{1}$ inems forsale Lap; ep Epi. politen; $m x$ Coxallappen.

4. En Coxallap isuleret wa stierkere forstorret, seet fin Iniluirlen.

5. En Forl af sillste 23rle l'ar, verl samme Forstorrelse situ Fig. 3.

6. Samme Firl, sterkere forstorret.

7 liagemen at Jegemet, reet trat venstre side

8. llaten seet bagira.

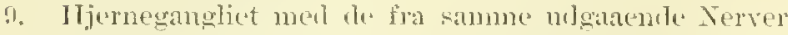

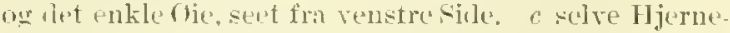
y:meliet; opt Sinsuerem; $a^{1}$ Xerver for 1ste Par Fulere; $a^{2}$ Vorver fur Litrerne; $a c$ llet enkle Oie; $x$ diettwe forreste lieament.

10. Nlernegangliet tilligemed de simmensatte Gine $O$, seet orenfr:t, $m$ biemuskler. The orrige Bogstarer whu par forengatemle Figur.

11. Thet enkle oice seet forfin.

12. Samme bagfia.

13. Simme merlenfra

14. Lin Del at Burgughekjuden, seut nerientra.

55. Jit lsarinm af et ganske ungt Inclivil].

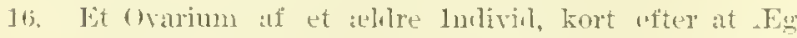
neme fra Folliklerme er indkommen i Ovarialroret. $x$. Jigleweren.

17. Et stykke af et anlet orarium, merl Egfollikler i forrkjellig lilrikling.

18. Furskiellige ligfollikier, isnlerede.

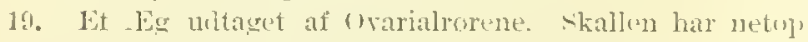
buymlt at diune sig.

20-22. Et fullfurrigt Egr meal sin kapsel, sect i 3 forshjellige Stillinger.

23. Jit styke af chen and ringefomige tovinhing af

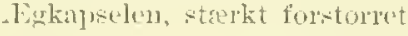

\section{Tab. XVII}

\section{Limnatia lenticularis, Lin.}

\section{[rivikingr:}

Fij. 1. En netop nulklitket Larve, reet nulentra. oc ilet wnkle Gie; $a^{1}$ ]ste P'ar Folere; $a^{2}$ alet Par Folere

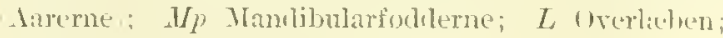
f Jaleindsnittet.

2. En larre efter 1sti' IJulskiftning, orenfra seet

3. Elilre Larve suet nerlenfra.

4. Et senere Stadiom, naa hrilket det forste Anlerge ti] die summensatte Gine. Rygskullet og Forlerno kan alikilles, secet oventra.

5. Eldre Jarre, seet netenfra.

5a. Fin Foler at 1ste l'ar, sterkt forstorret.

b. Eit noget aldire stalium, seet fra venstreside. Ven stre dare er mleladt

7. Siskte Larvextalliun, ovenfra suet.

S. Inge i 1ste postlarvale Starimu, seet wenfm.

(4) Simmer seet fra venstre fille.

\section{Tal, XYIII.}

\section{Limetis brachyurys, Müll.}

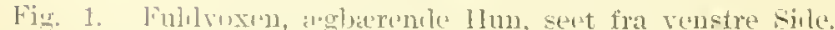

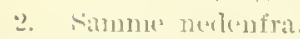

3. Fuhlvoxen Jian, secet fra hoire sisle.

4. Jloveriet af ('n 11 un, seet foriral.

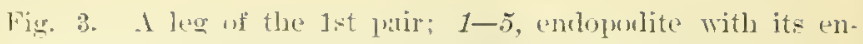
lifos: ex, exopolite; $e x^{1}$, dorsal lobe ot the latter; ep, "pipurlite; ms. cuxal lube.

4. A coxal lobe isolater ame more highly magnifier secen finoll insirle.

5. I leg of the last 23rd pair, muler the same man uifying mwer as fir. 3.

6. Same leg, more highly magnified.

7. Posterior end of lwaly. seen firm the left.

8. Tail, secen from lowind.

9. ('ereloral tanglium, with the nerves issuing from it, and the reellus, seen from the beft. c, eerelual ganslion: opt, optic nerve; $a^{2}$, nerves tur the lst jair of antemer $a^{2}$, nerves for the rars; $o c$, wellus; $x$, the tiont lisament of the ocellns.

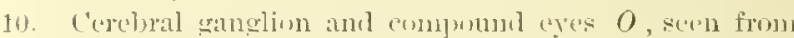

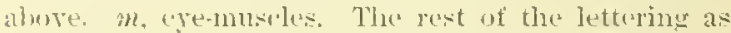
in tio. 9 .

11. owellus, secen from the fromt.

12. Same, trum hehinal.

13. Simue, frumi below

14. l'at of the ventral ganglion chain, stent from bestw.

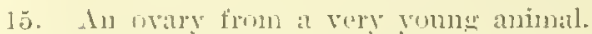

16. In wary lrom an ollex animal, soon after the eges from the follicles have "ntered the warial tule. $x$, orilnet.

17. l'jece of an wriry, with cog-follicles in different stages of divelopment.

18. Vilrious cugrefollicless, isolated.

19. An "gug taken out of the "rarial tube. The shell Jas just bureun to furm.

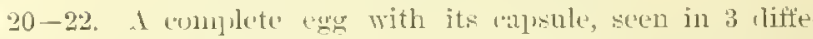
rent positions.

23. I'iere of one wiug-like expansion of the exg-capsulte lighly maguifier.

\section{Plate XYII.}

Limmadir Tenticularis, Lin.

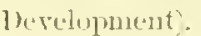

Fig. 1. A newly-hatcherl larva, seen from helew. oc, ocellus:

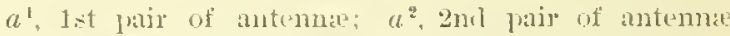
oars; $U_{p}$, mandibular legs:; $L$, labrum; $f$, caudal emargination.

2. A larva diftex the lat exuriation, seren from above.

3. An oleler larra, secule frou bejow.

4. 1 liter stare, in which the erricst rudiments of the compouml eyes, the caranace and the legs axe ris tinguishable: seren from anwre.

5. (1)]er latrva, seen frum helow.

5a. In antemat of the ist pair, highly magnifies.

6. I sommont later stage, seen from the left. Left rals wuitterl.

7. luast larval stage, seen from above

8. Jutung une in the list frost-larval stage, seen from above.

9. Simme, sien from the left

\section{Plate XVIII.}

Limnetis brachyume, In̈ll.

Fig. 1. Full-gomn, wigerems fomale, seen from the left.

2. Fance, fiom below.

3. Full-gawn male, seen from the right.

1. Hoxil of a temale, sien from the front. 
Fir. 5. Horeclet af en Han i samme stilling.

, 6. Skallen at en flun, merl Vilvterne tret lukkerle, scet fra venstre sille.

7. Simme orenfial,

\section{Tab. XIX.}

\section{Limmetis brachymors, Minll.}

Fig. 1 Legemet af an thun liggente $i$ sin natmlige situs i hoire Vilvel; renstre Valvel borttaget. h Hjestert; ovs en at de kageformige liymassir.

2. En Foler af tste l'ar.

2a. En af de bial sammis tiestede Lugtepapiller, stirkt forstorret.

3. En Foler af zilet Par Aare\%

4. Mlundregionen seet nedentra; Gverleden burtaget. M Kindhakkerne; $m^{1}$ 1ste Par Kjarer; $m^{2}$ 2det Par Kijerer; oes ipiseroret.

5. Ln Kivire af 1ste l'all.

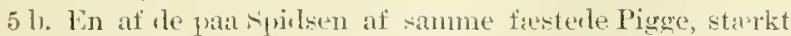
forstoret.

6. En Kijere af wilet Par.

7. Haledelen seet fra remstre side.

8. Sammir nedentra.

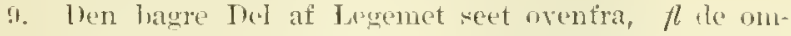
formede dorsale Lappe af bxopoditerne paa gde og 10ile Forlpar; $l$ de hladfomige torvaleplader; $u$ HaleHigene.

10. Hjertet seet oyenfra.

11. let forreste dfonit af Jegrmet af en 1 lun, seet fia renstre sidte Aarerne udelatte). O de sammensatte Oine; oc let enkle Ole: $p$ rettes forreste Liganent; $o l$ Sandergrulier; $x$ Fastheftningsorgan ?); $a^{1}$ 1ste Par Folere; $L$ wrereden; $U$ Kindbakkerne; $m^{2} 1$ ste Par Kiferer; $m^{2}$ 2ulet lar kjacer; ms Insertiensarea for skallens Jukkemuskel; I Tarmen; $l v$ Lereren.

12. En tambegrube soet wentrat.

13. IJjernegangliot med de fra samme udgatende Nerver, tilligemed de sammensatte Oine $O$ ogr det enkle ofie oc, seet netenfra; opt synsnerven; $a^{1}$ Server for 1ste Par Folere; $a^{8}$ Nerver for Aareme.

1. Summe bel ulen de sammensatte Oine', seet fra vemstre Sille. Bogstaverne som par toregaame Figur.

15. Thet enkle bie reet forin.

16. Skalkjirtelen med Muskelareaen.

\section{Tab. XX.}

\section{Limnetis brachyurus, Minl.)}

Fig. 1. En Fod af Brlie Par hos Humen, 1-5 Endopoditen ned sine Enditer; $m x$ Coxallappen; ex Exoporlitens ventrale Lap; $e x^{2}$ dens torsale Jap; ep Epipoditen.

1 a. En af de til nastsidsto Endit festede 'lorne, sticrkt furstorret.

1 b. coxallappren isoleret, og sect fra then intle silde.

2. En Fort af site Par.

3. Lin Fut af ghe Pay.

3 a. Enden af Exopoditens dorsale Lap, starkt forstorret.

4. Lin Fod af ifte Par.

5. En Forl af 12 silste) Par.

6. Legenet af en Han liggende i sin naturlige situs i renstre Valvel hoire Valvel borttaget).

7. Fu Fod af 1ste Par hos Hannen.
Fig. 5. Hear of a mule, in the same josition.

ti. Shell ot a temale, with the valves elosely shnt, seen frons the left.

7. Same, from alove

\section{Plate XIX.}

Limetis brachyures, (Minll.)

Fig. 1. Fouly of a fomale, lying in its matural position in the right shell; left valve removed. $h$, heart; ors, one of the cake-like ego-masses.

2. In antenna of the 1st pair.

2 a. One of the oltatency papille on the same, highly masnified.

3. In antenna of the 2ud pair ioarsi.

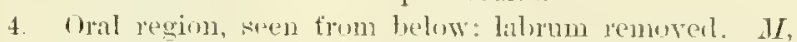
uandililes; $m^{1}$, 1.t pair of maxiltse; $m^{2}$, znd pair of maxillie; oes, resophagus.

5. I maxilla of the 1st pair.

5h. One of the spines at the end of the same, highly magnifiet.

6. A hiaxilla of the end prair.

7. Caulal part, exen from the left.

8. The sime, from ledor.

9. Posterior part of the horly, seen from ahove. $\pi$, the transformed thosal lobes of the exoportites in the 9 th and 10th pairs of logs; $l$, the leat-like lursal lamellse; $u$, watulal lubes.

10. Heart, seen from alwse

11. Interior part of the borly of a temale, seen from the left. Oills umitter, $O$, womponnd eres; oc, ncellus; $p$, its firont ligament; ol, sensory pits; $x$, aftixing organ ? ; $a^{1}$, 1st pair of antenne; $L$, lahrnu; $M$, mandililes; $m^{1}$, 1 st pair of maxille; $m^{2}$, and pilir uf maxil]er; $m s$, areat of insertion of the adduetor nuscle of the shell; $I$, intestine; $l x$, liver.

12. A sensory pit, seen from above.

13. Cerelual ganglion with the nerves issuing from it, and the componnd exes $O$ and oedlus $\langle o c$, spen from belus. opt, "nutic nerve; $a^{1}$, nerves for the 1 st. pair of antenne; $a^{2}$, nerves for the oars.

14. Sane part without the eompound eyes, seen from the left. Lettering as in fig. 13.

15. Geellus, sean from the front.

16. Shell-gland with muscular area.

\section{Plate XX.}

\section{Limnelis brechyume, Mlïll.}

Fig. 1. A leg of the 3rd pair in the female. 1-5, entopodite, with its enclites; mx, coxal lobe; $c x$, ventral lobe of exopodite; $e x^{2}$, its lorsal lobe; $c p$, epipolite.

fa. The of the spines on the perultimate endite, highly magnified.

1b. Coxal lobe isolaterl, and seen from:the inside.

2. I lege of the Stla pitix.

3. I leg of the oth pair.

3 a. Encl of torsal lolue of exoporbite, highly mannifiecl.

4. A leg of the 11th pair.

5. I lege of the 12 th last pair.

6. Borly of a mate lying in its natural position in the left valve right ralve removed.

7. A leg of the 1st pair in the male. 
lig. s. Det ridre l'arti af amme Haburlen. sterkere forrsturret.

1. Lin Forl af 2iket l'ar lus llamen.

a) aiestsidste Endit, stierkere forstorret.

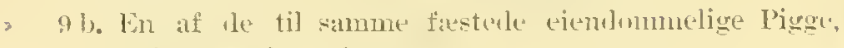
emelnu starkere forstorret.

10. Haledelen af en Han, seret fral hoire sith.

11. Nogle sittlollikler, stient forsturrerle.

12. Et strkke af en af sadstokkene.

13. Det forreste Parti af et isarimm.

, 14-17. Egfollik]er i torskjullig [tovikling.

18. En Gruple af . Eg tagne fra an af dle kageformige Eimiarer.

211. Et Stykk af Buggangliekjicden, seet nerlentra.
Fig. 8. Outer part of the sane lamed, higlyly magnitiesl.

5. 1 ley of the end fair in the male.

9 a. Last undite but one, highly magnifierl.

- 9 b. Ine of the peeuliar spines on the same, still mone high!y magnitierl.

10. Candal part of a male, seen from the right.

11. Some sperm-tollicles, lighly magnified.

- 12. l'iece of une of the tester.

13. Anterior part if an warry.

- 14-17. Fige-fullicher in different stages of develepment.

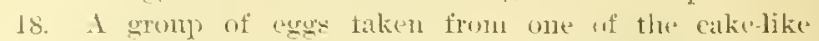
egg-massest.

2 19. I finese of the ventral ganglion chain, seen from below. 


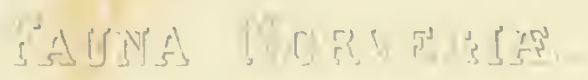

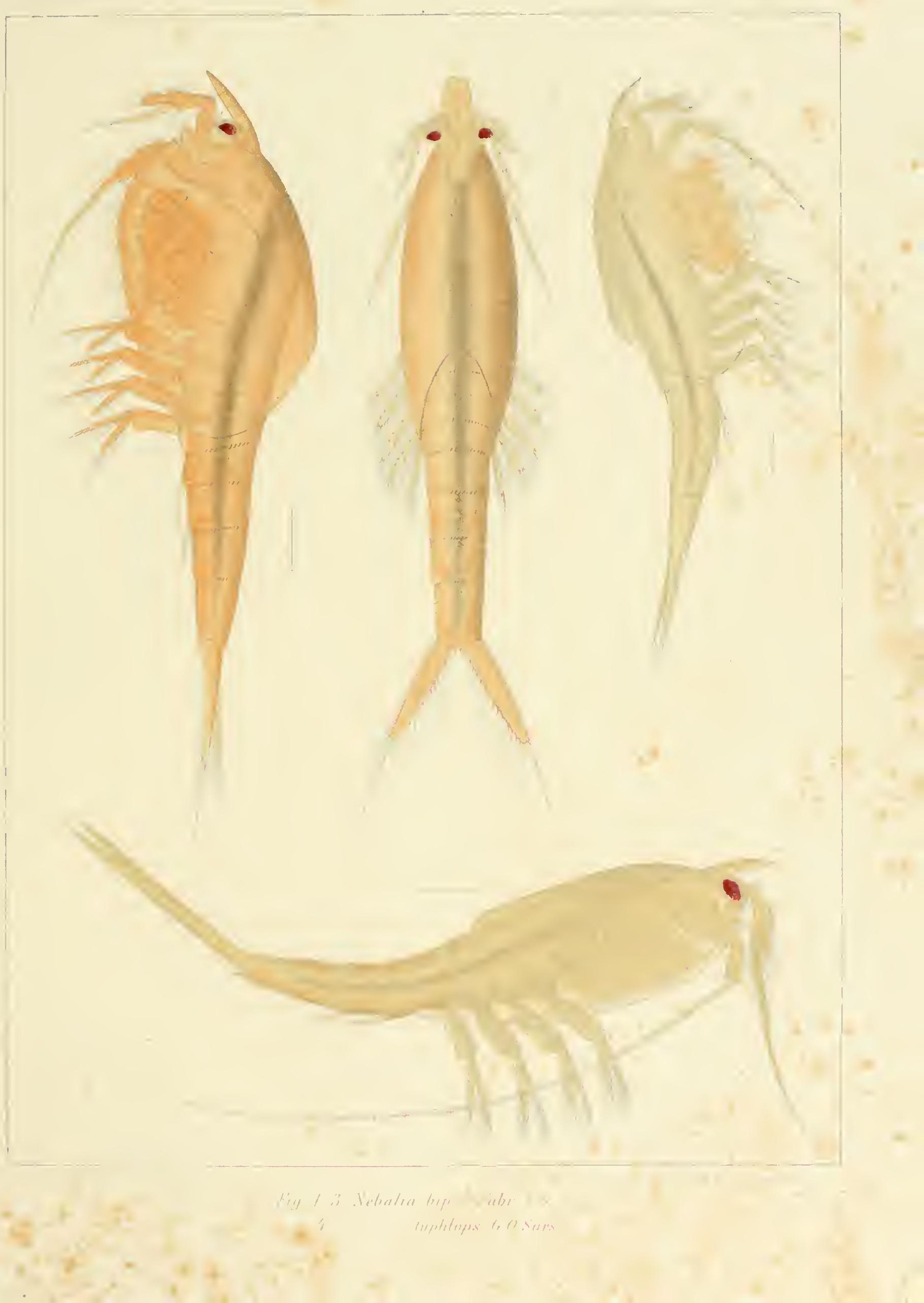





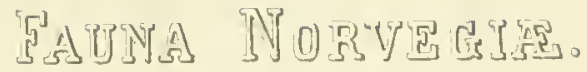

(Crustacea)

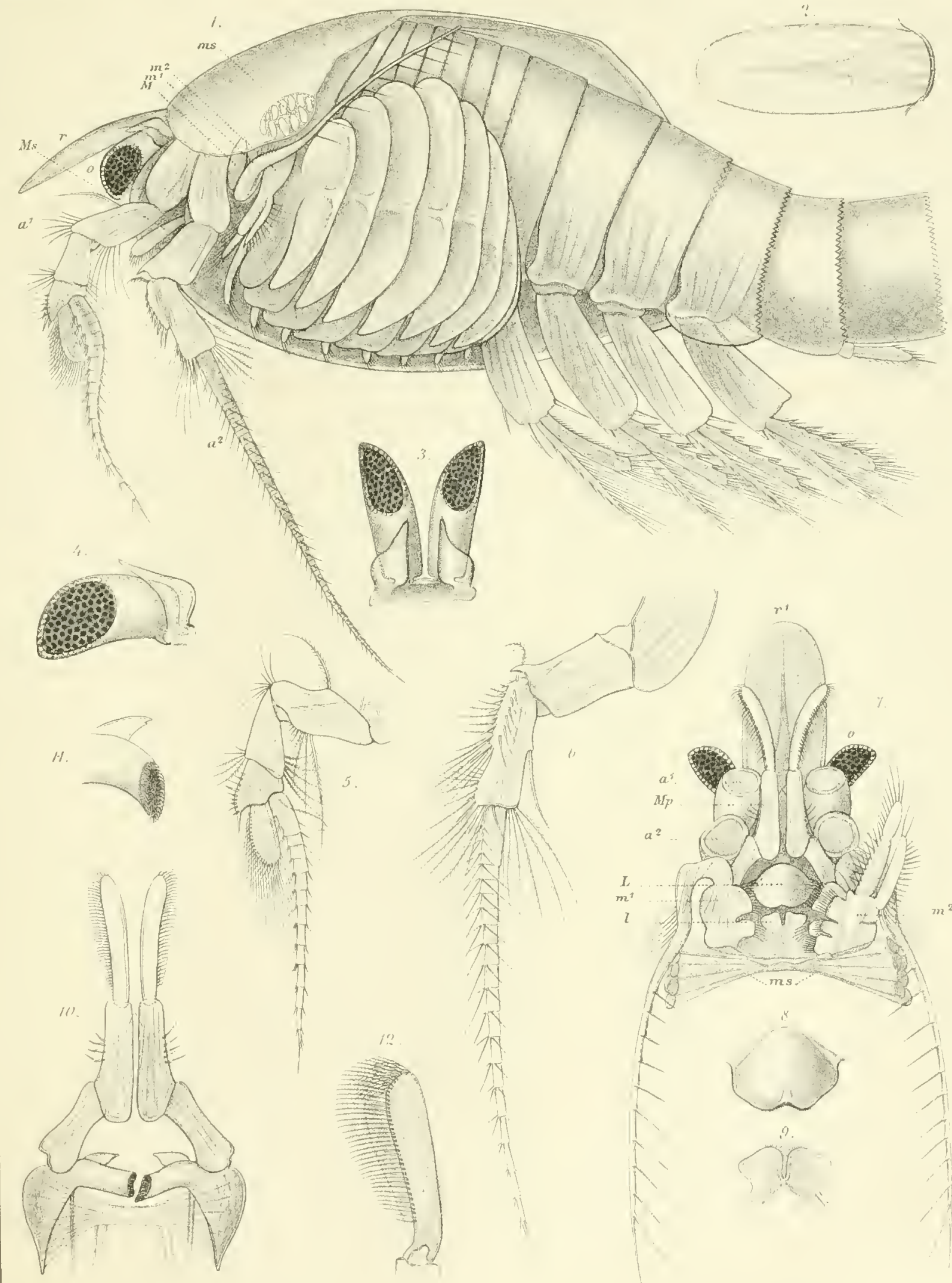





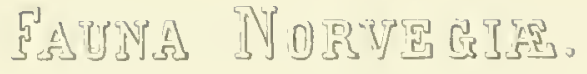

(Crustacea)

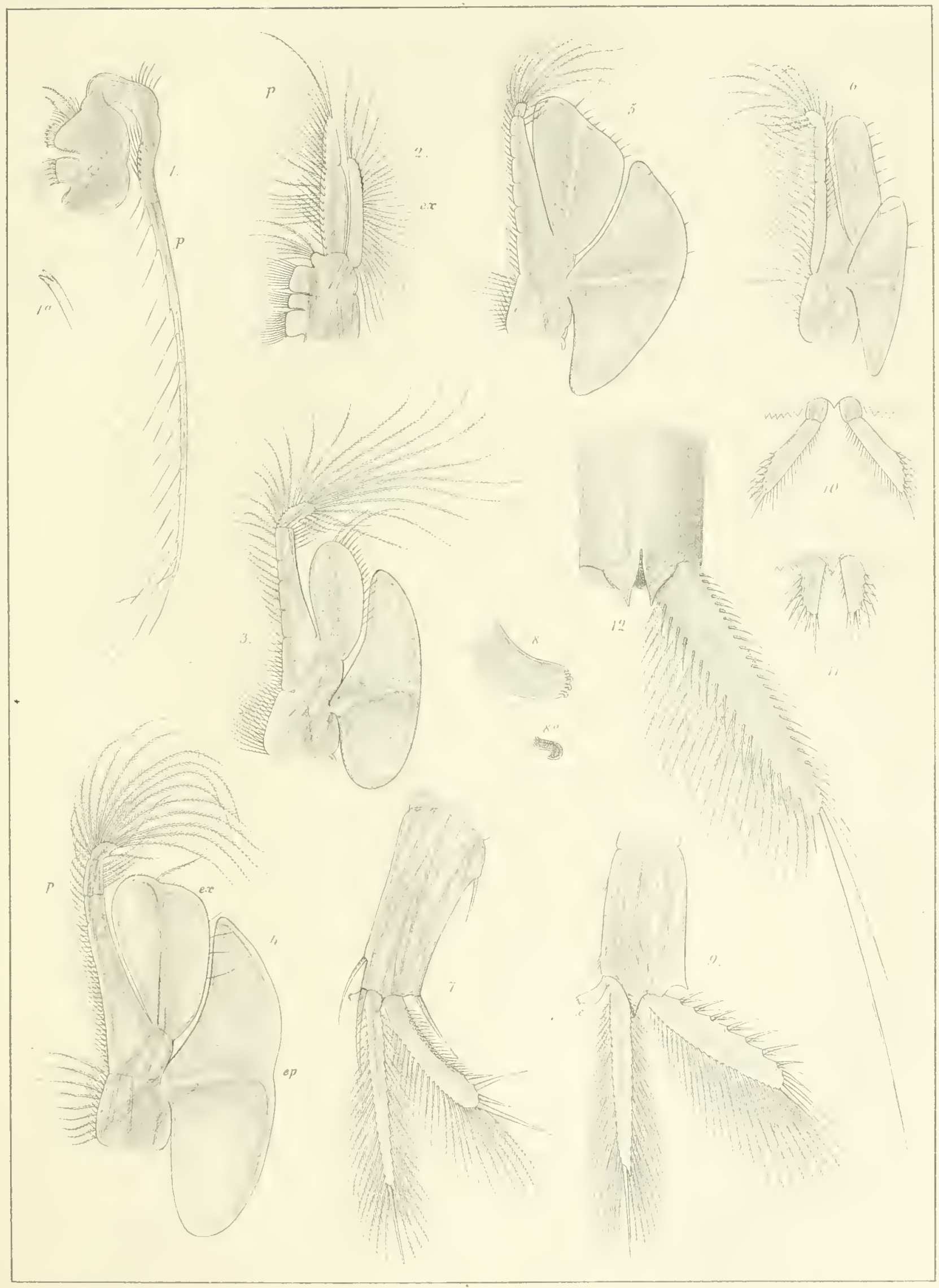





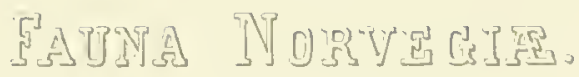

(Crustacea)

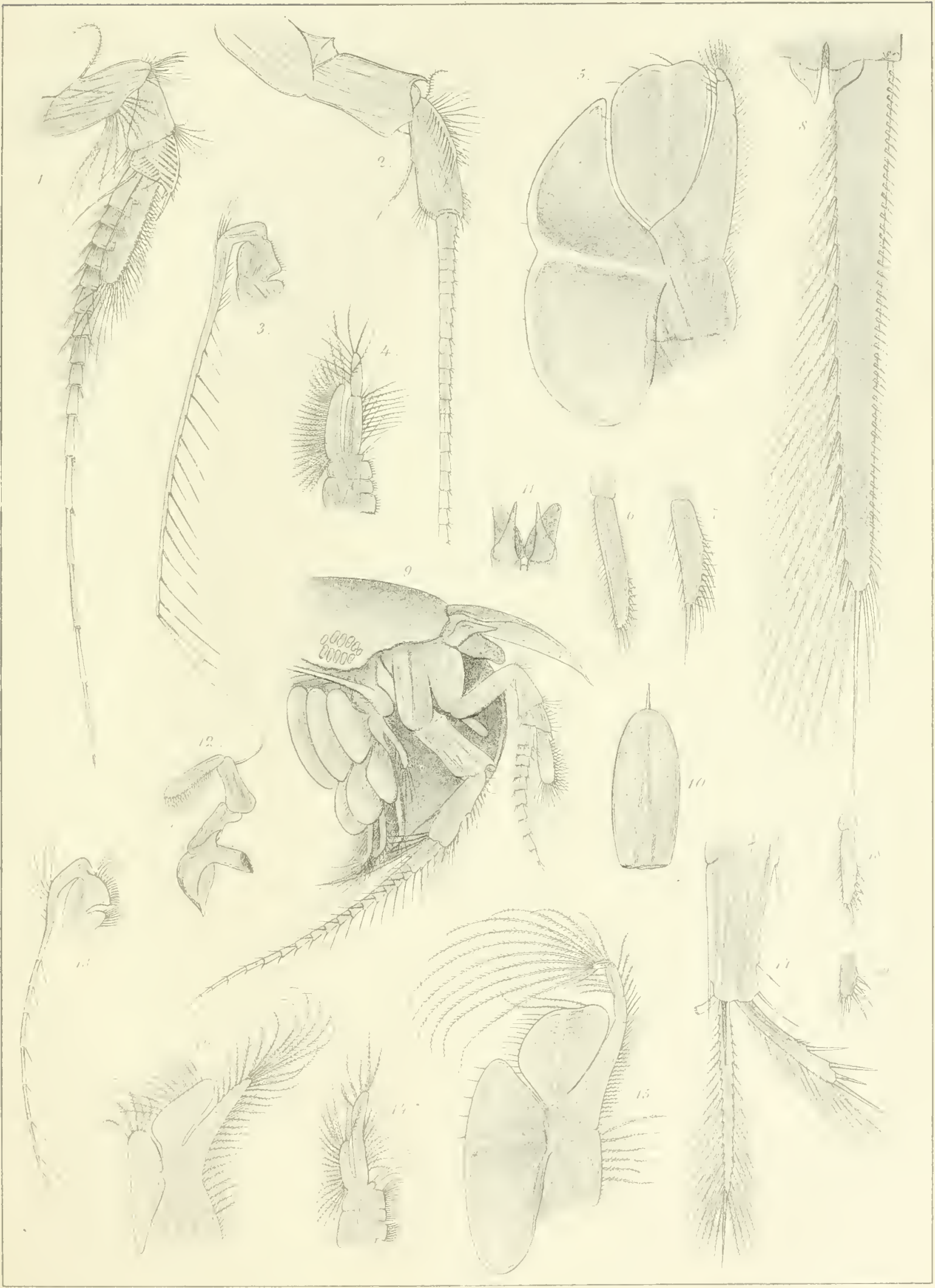

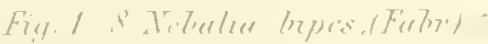

Fiy. ") I." typhlops, (1) Sines 



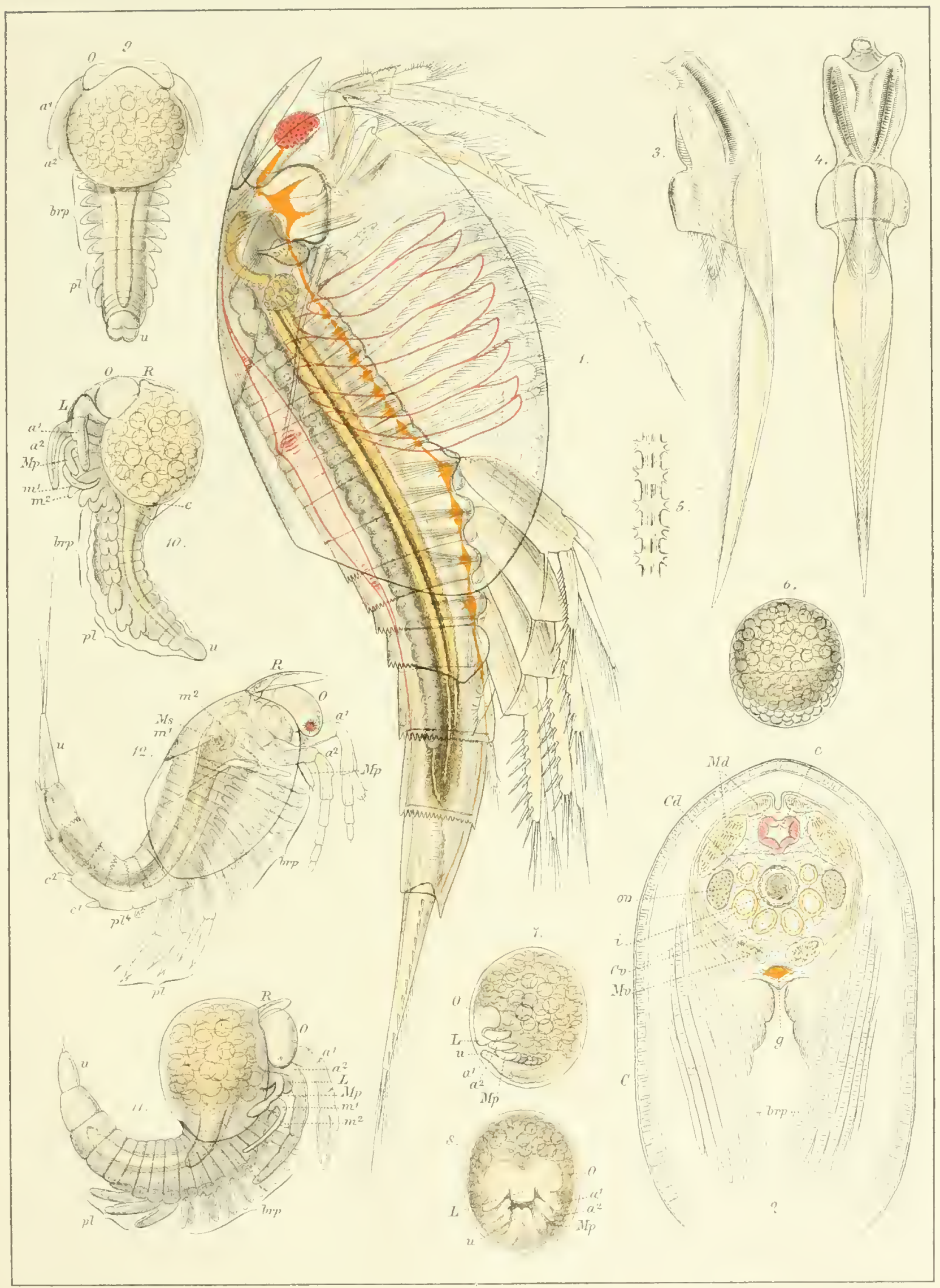





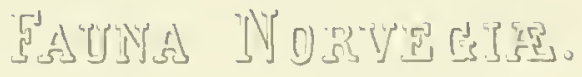

(Crustacea)
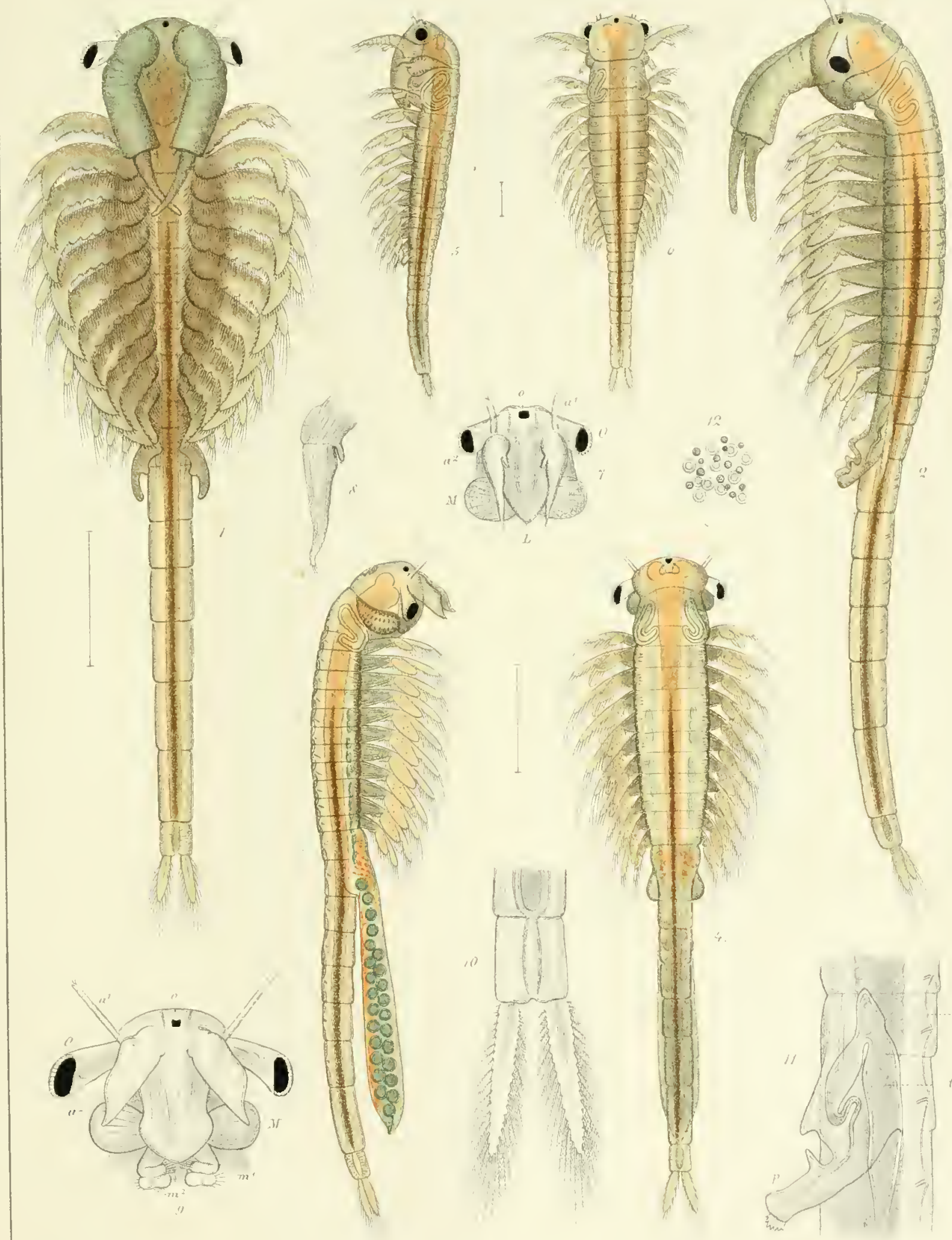



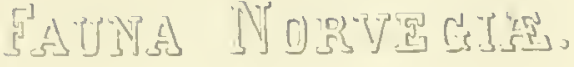

(Crustacea)

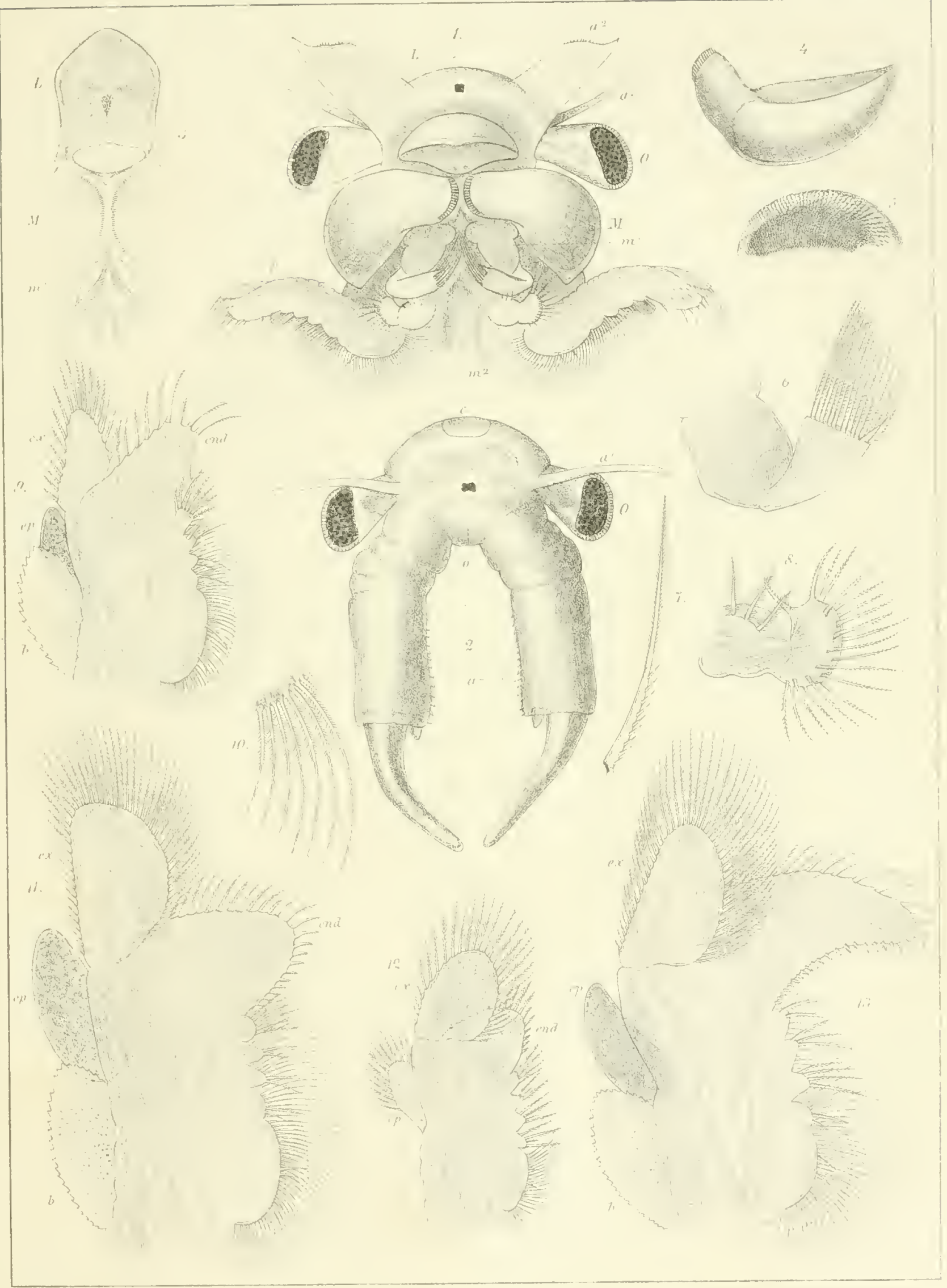





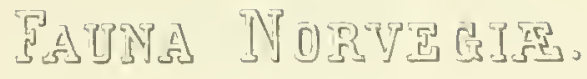

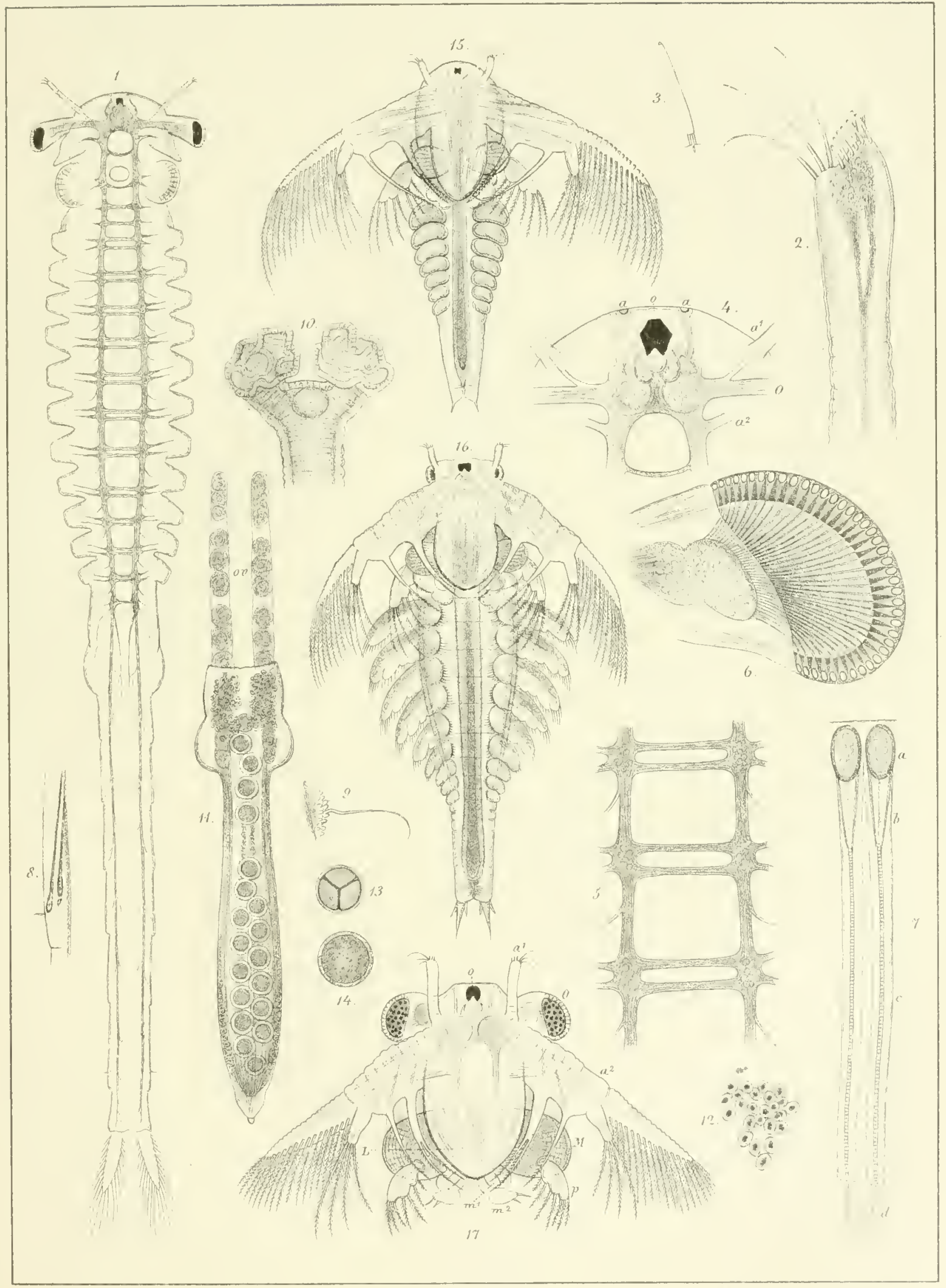

Branchineda pahudosa, MMuller). 



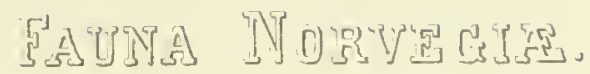

(Crustacea)

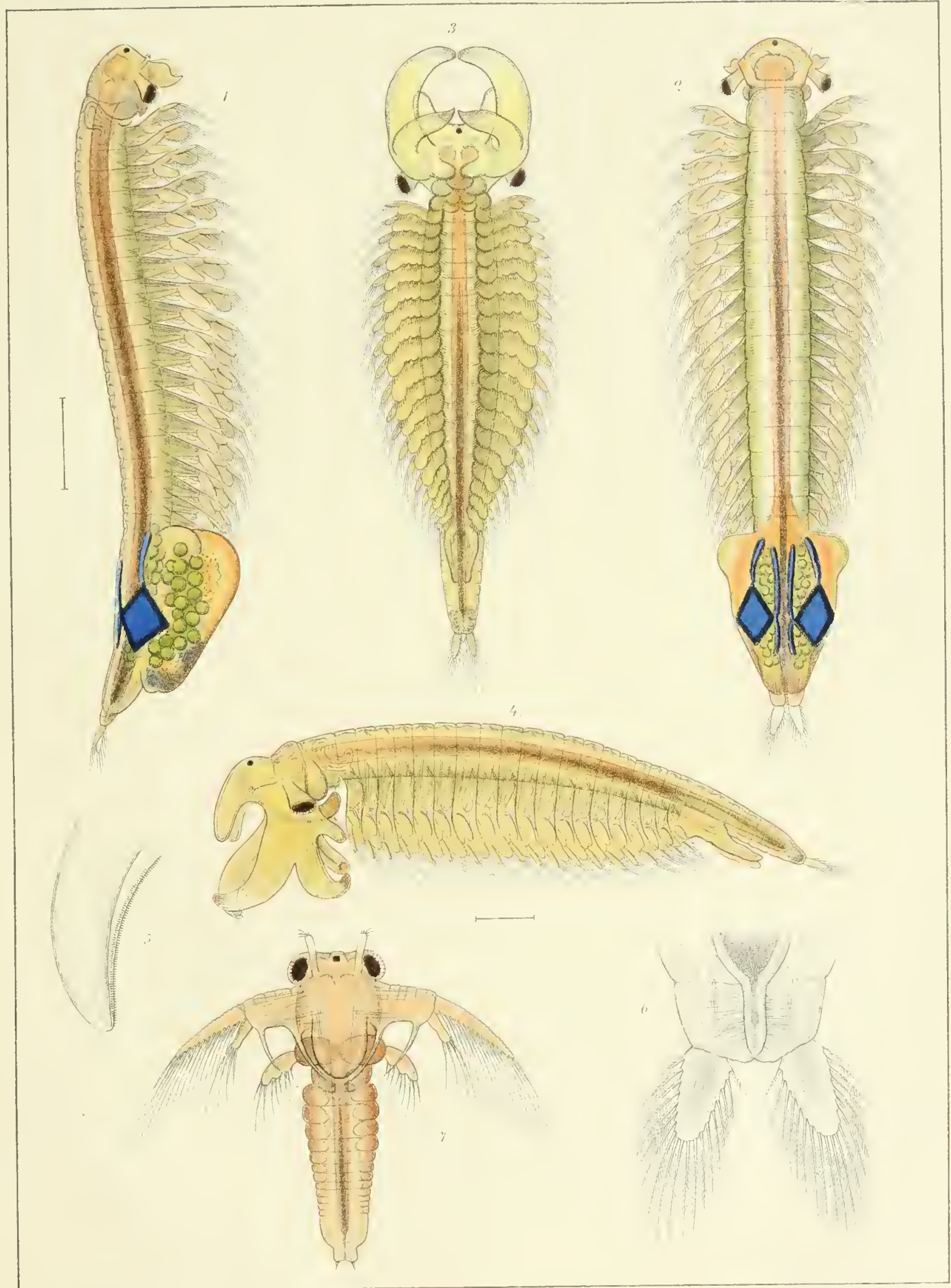





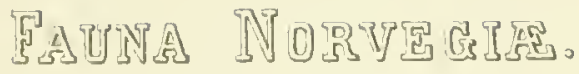

(Crustacea)

Ta X

Phyllo, di
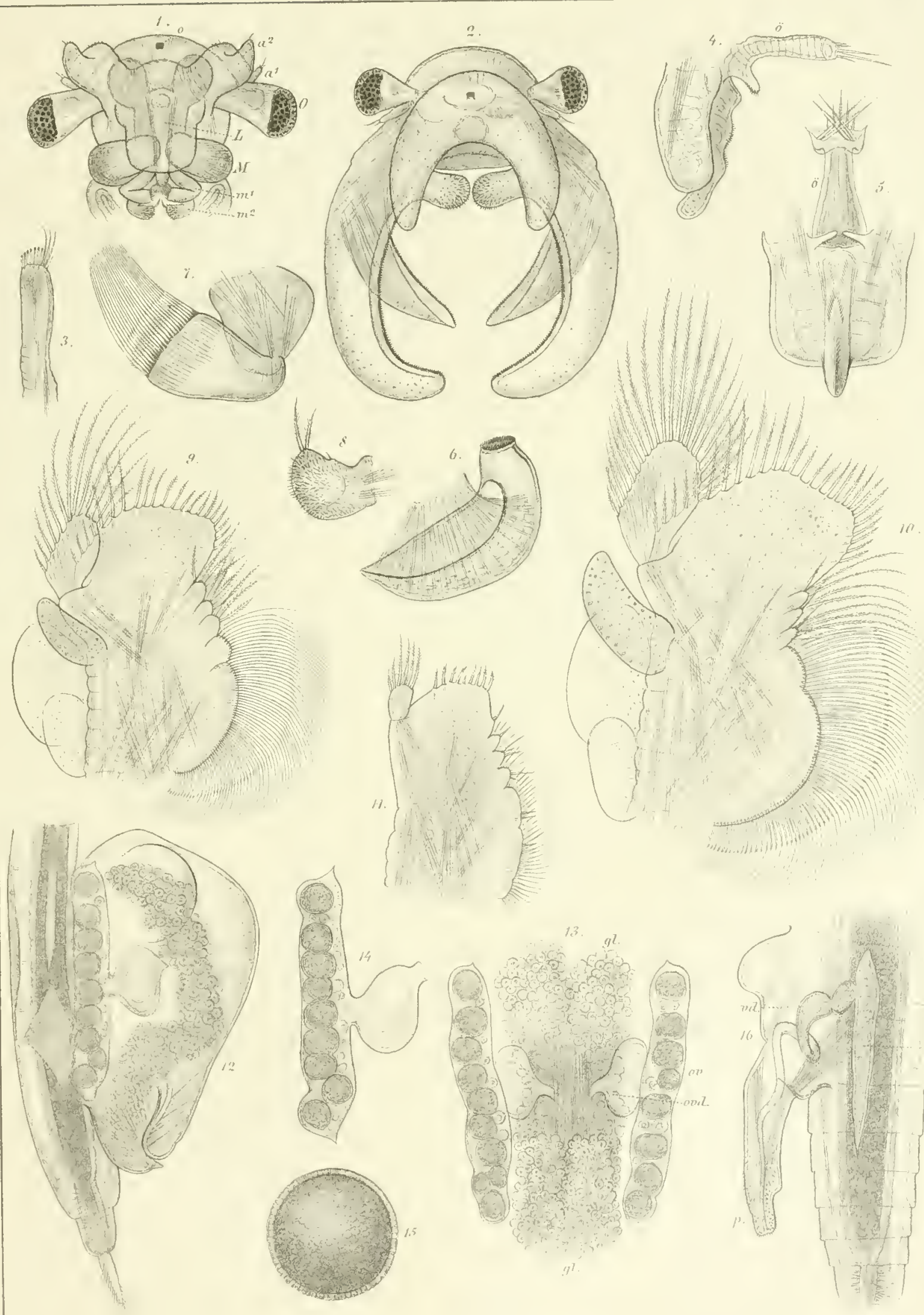

马AT N

Phyllopulia

(Crustacea)

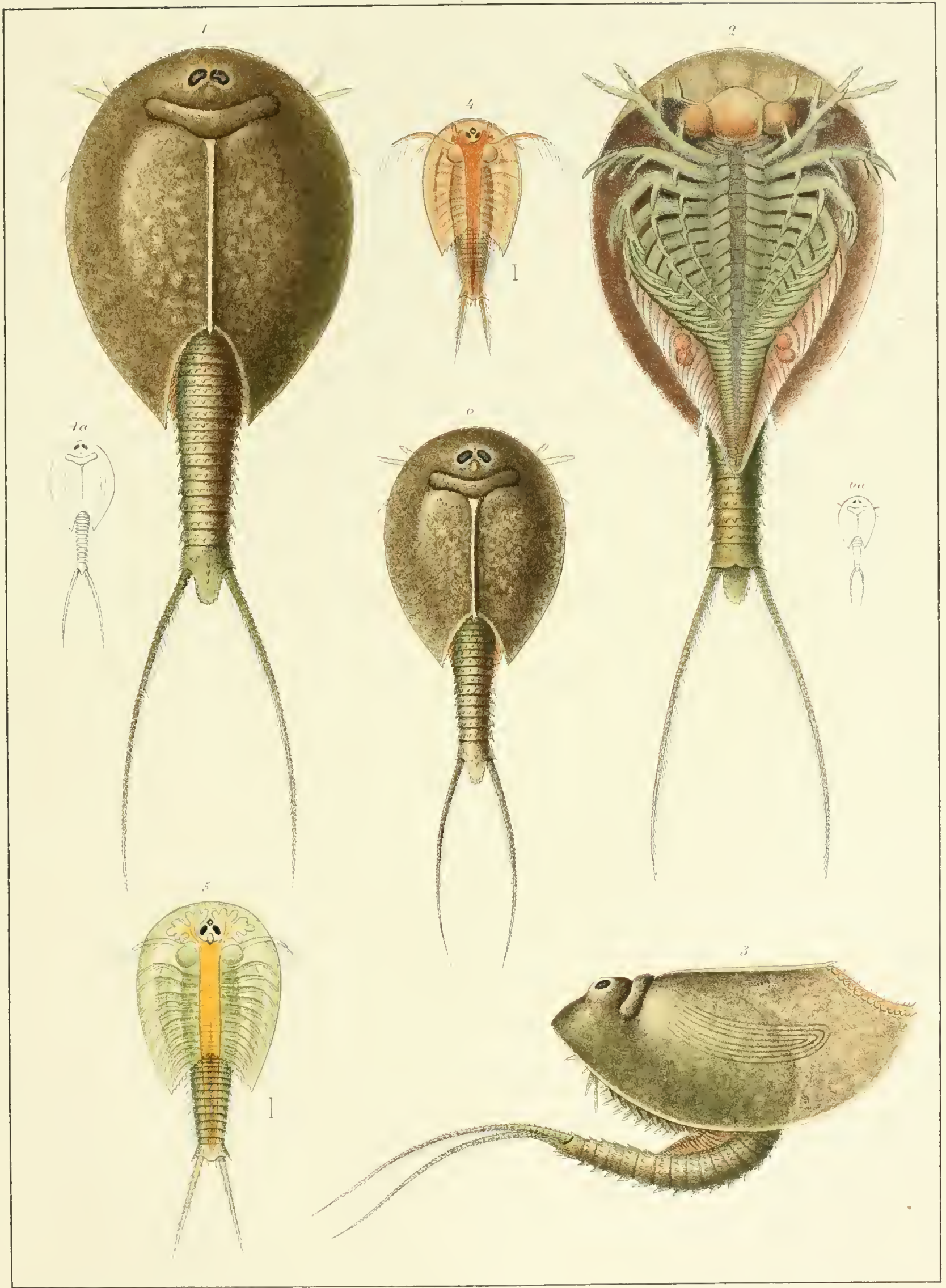

Lopriduress olarialis, fironer\% 

FAONA NDOBN

(Crustacea)

Tah XII.

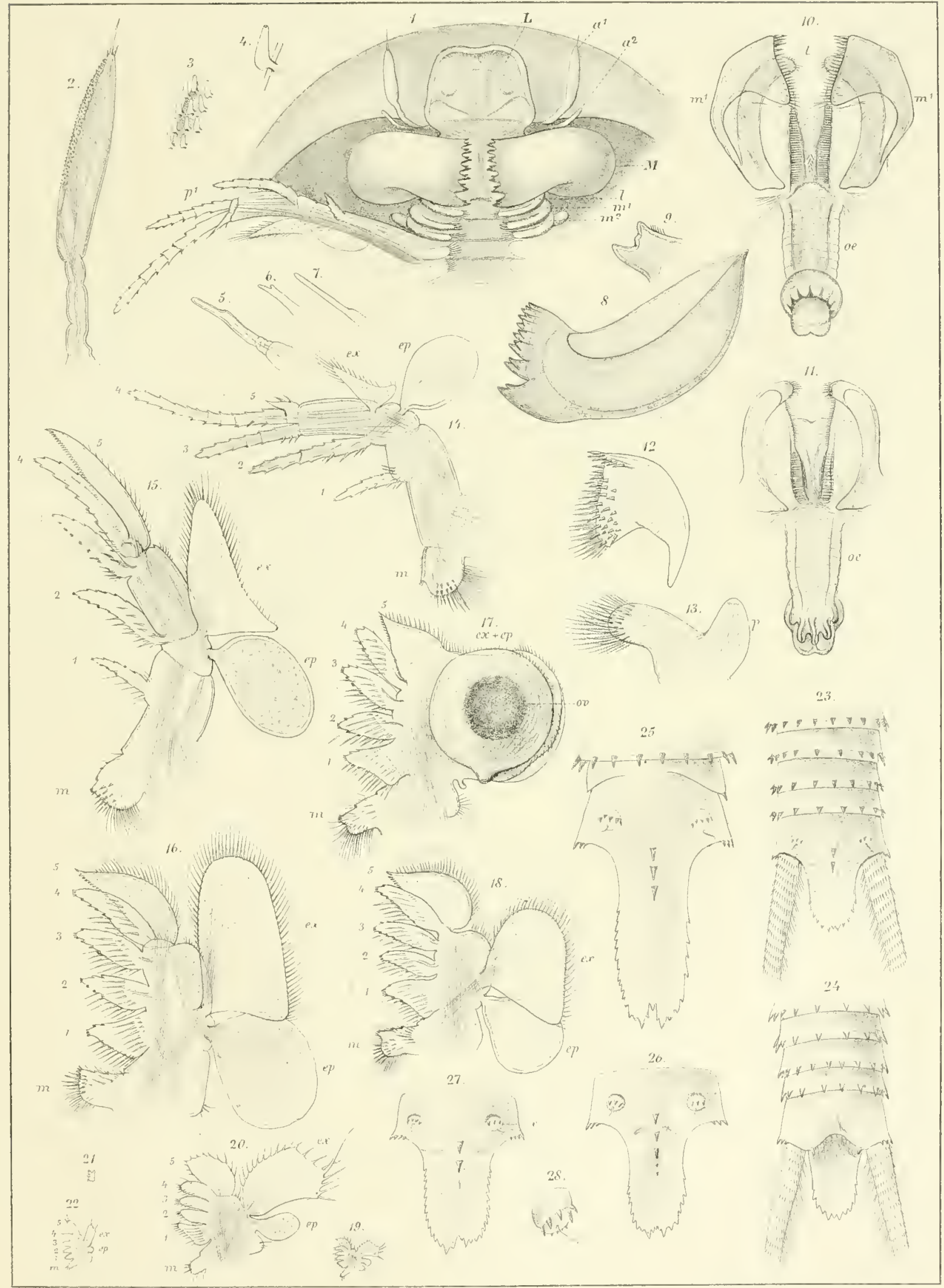

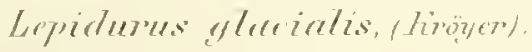





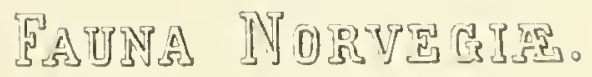

(Crustacea)

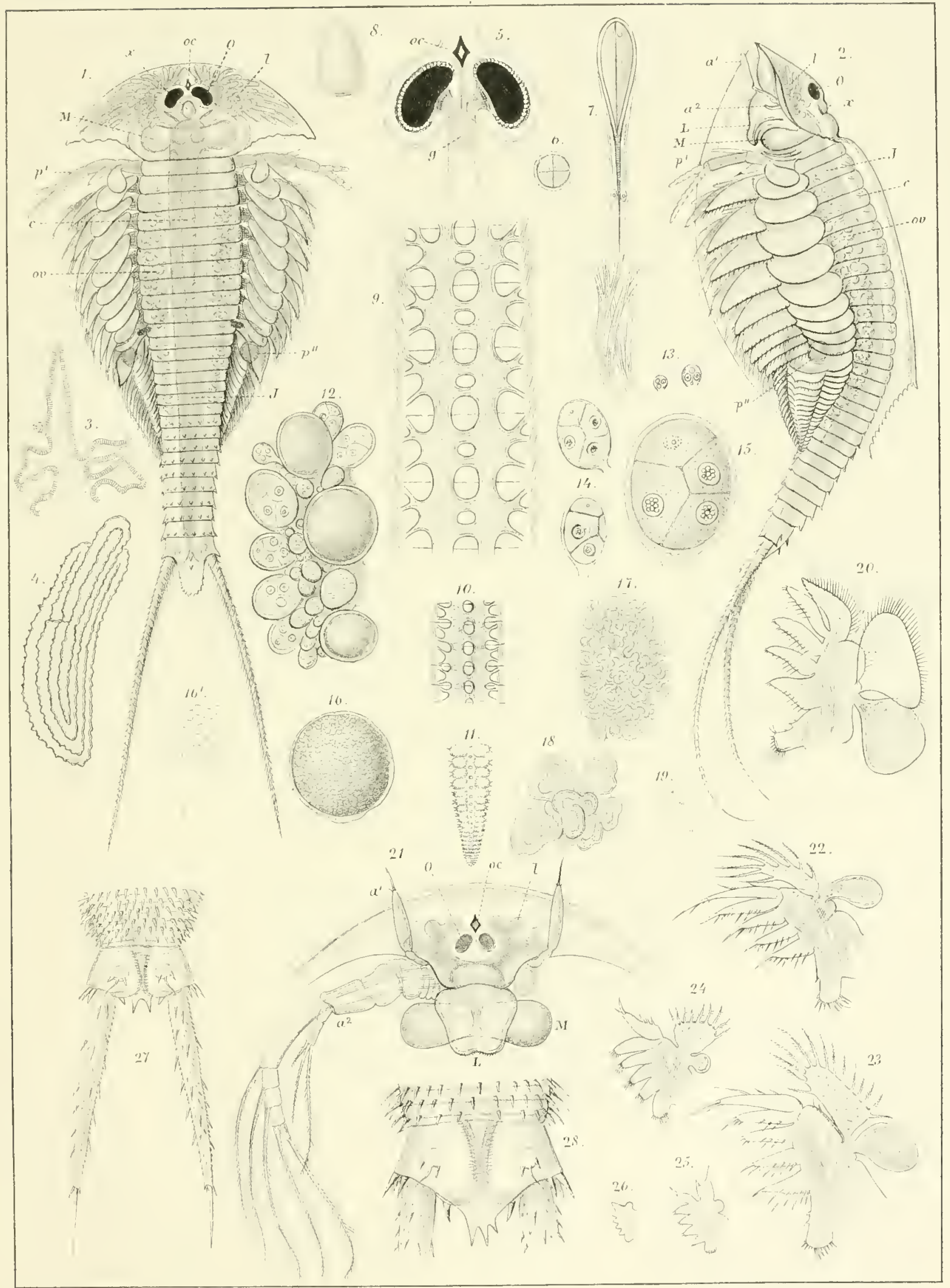

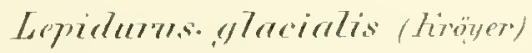





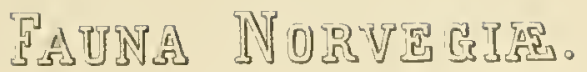

(Crustacea)

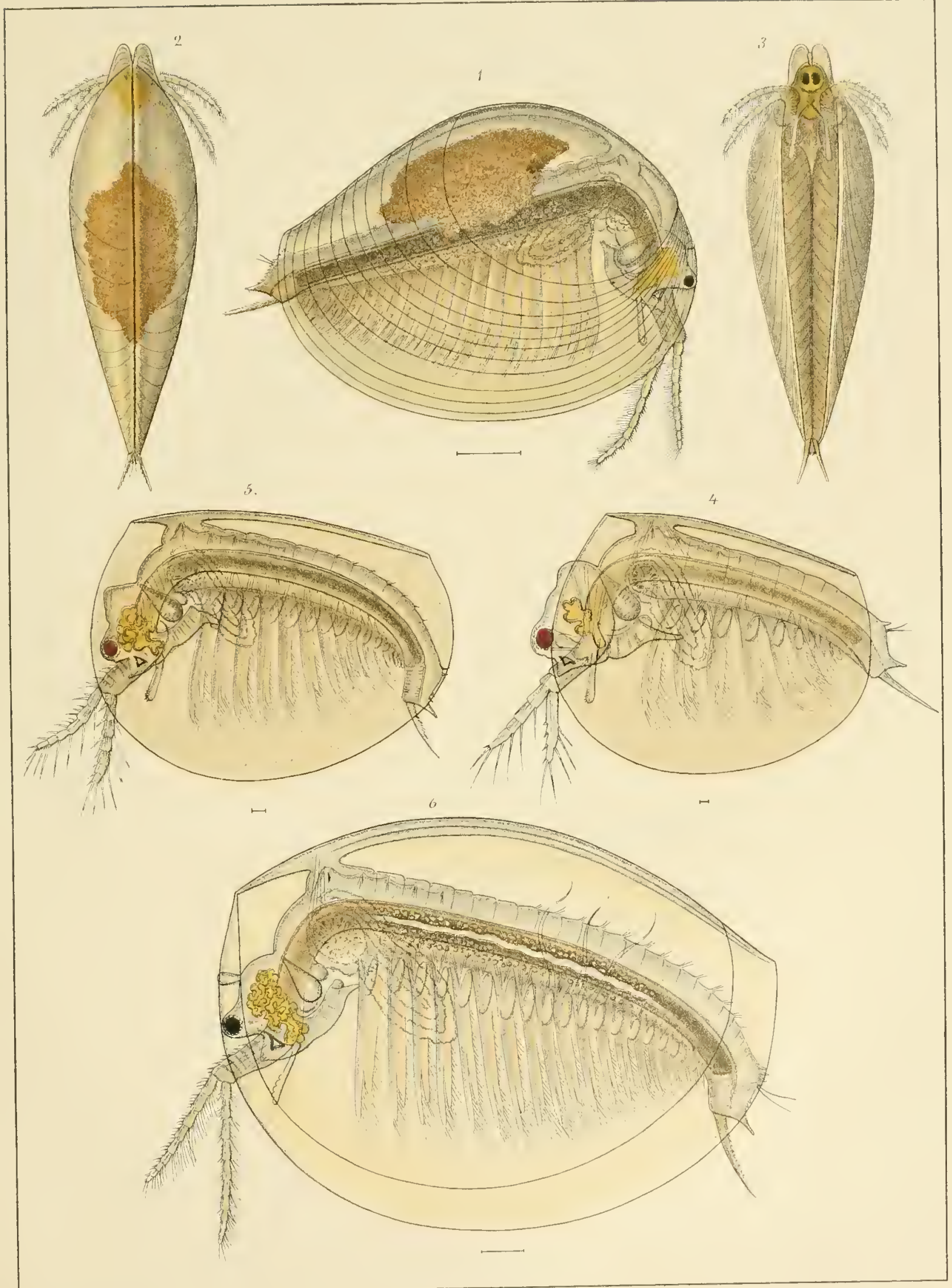

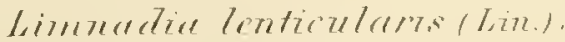





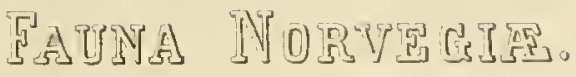

(Crustacea.)

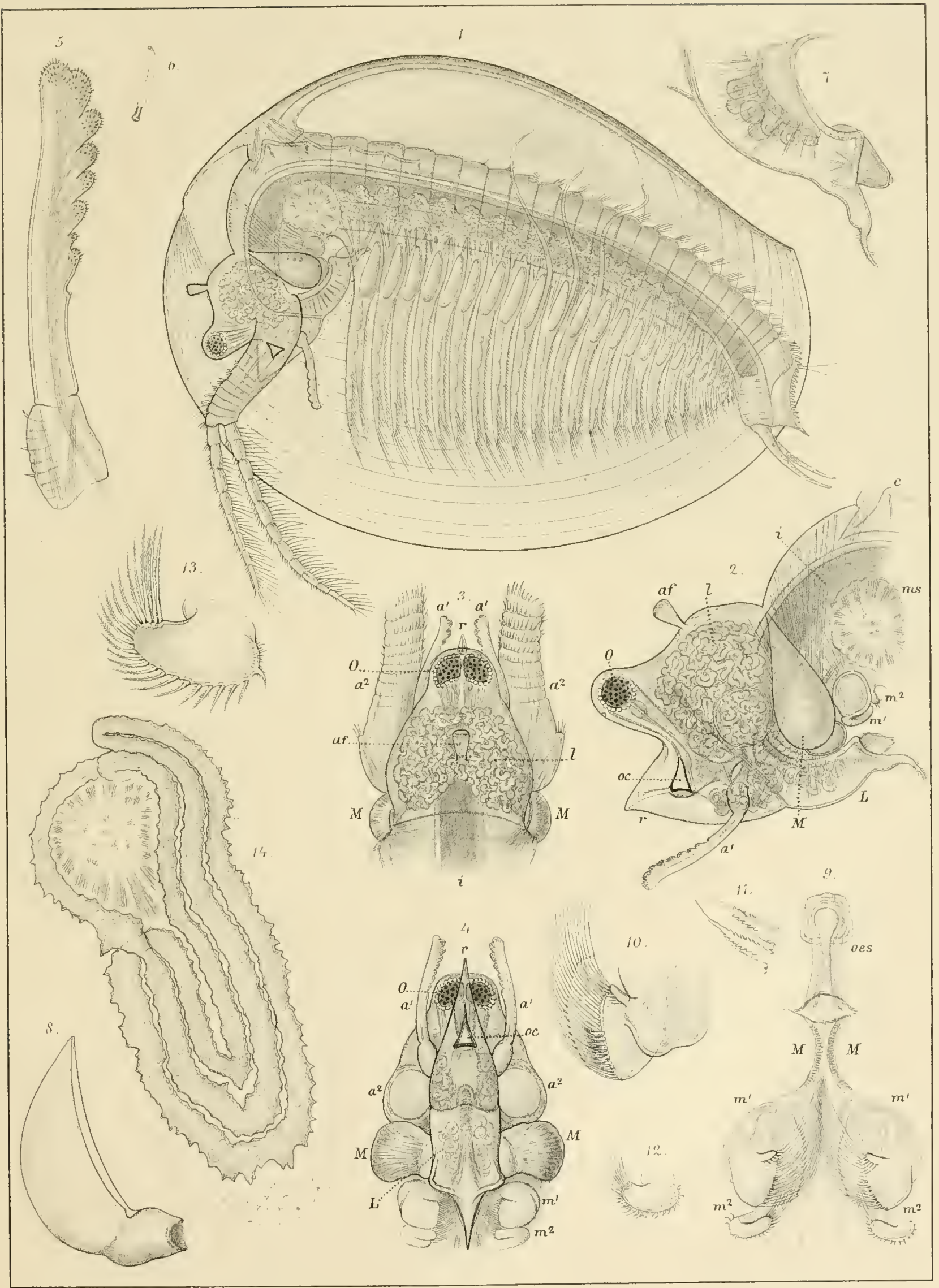

Limenertier Tenticulartes (Lin.). 



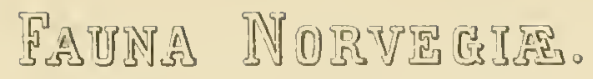

(Crustacea.)

Tab XVI

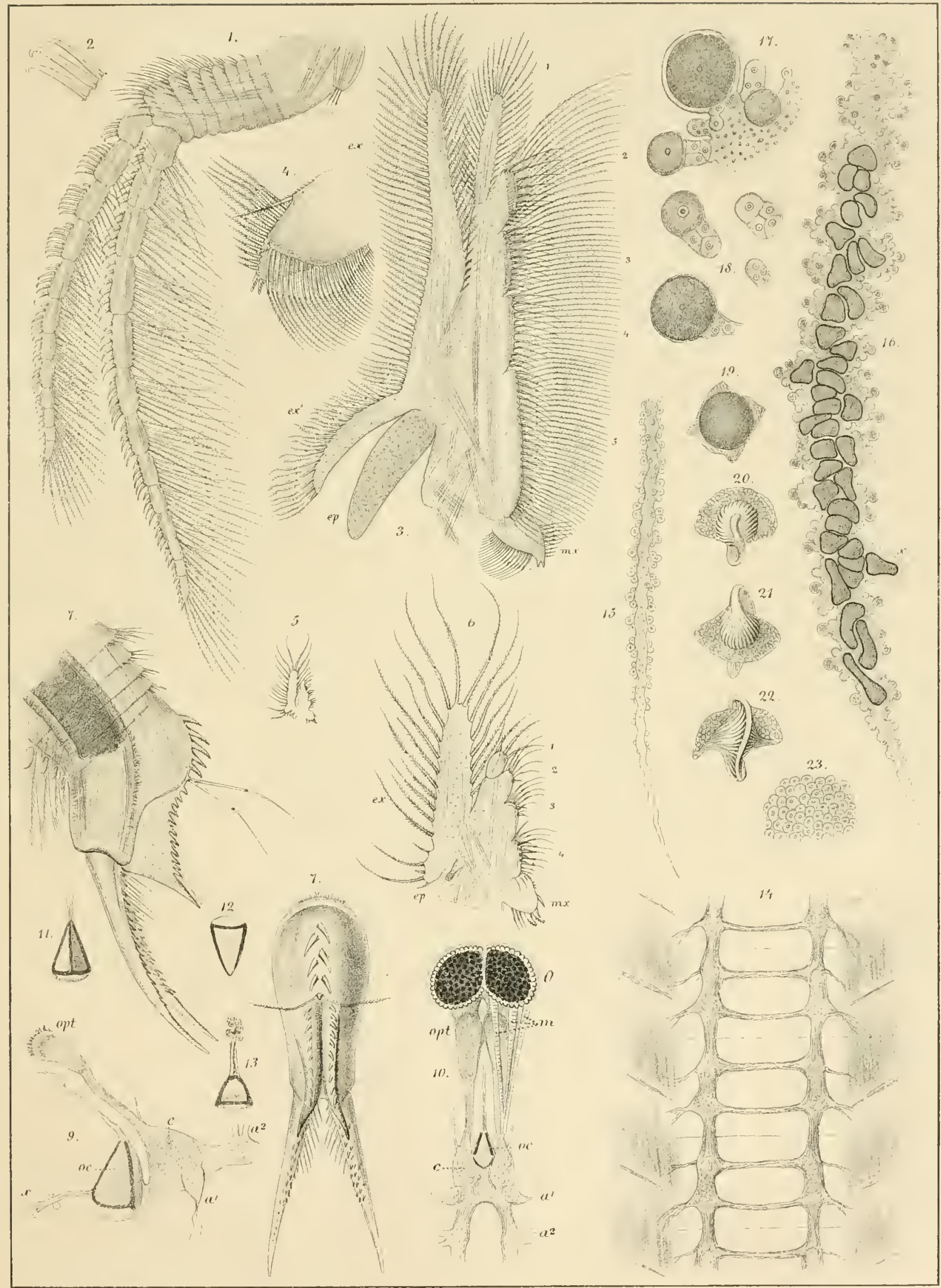





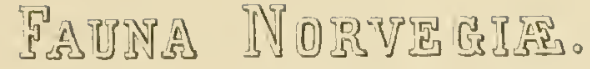

(Crustacea.) iab.XVII.

Proylingad:

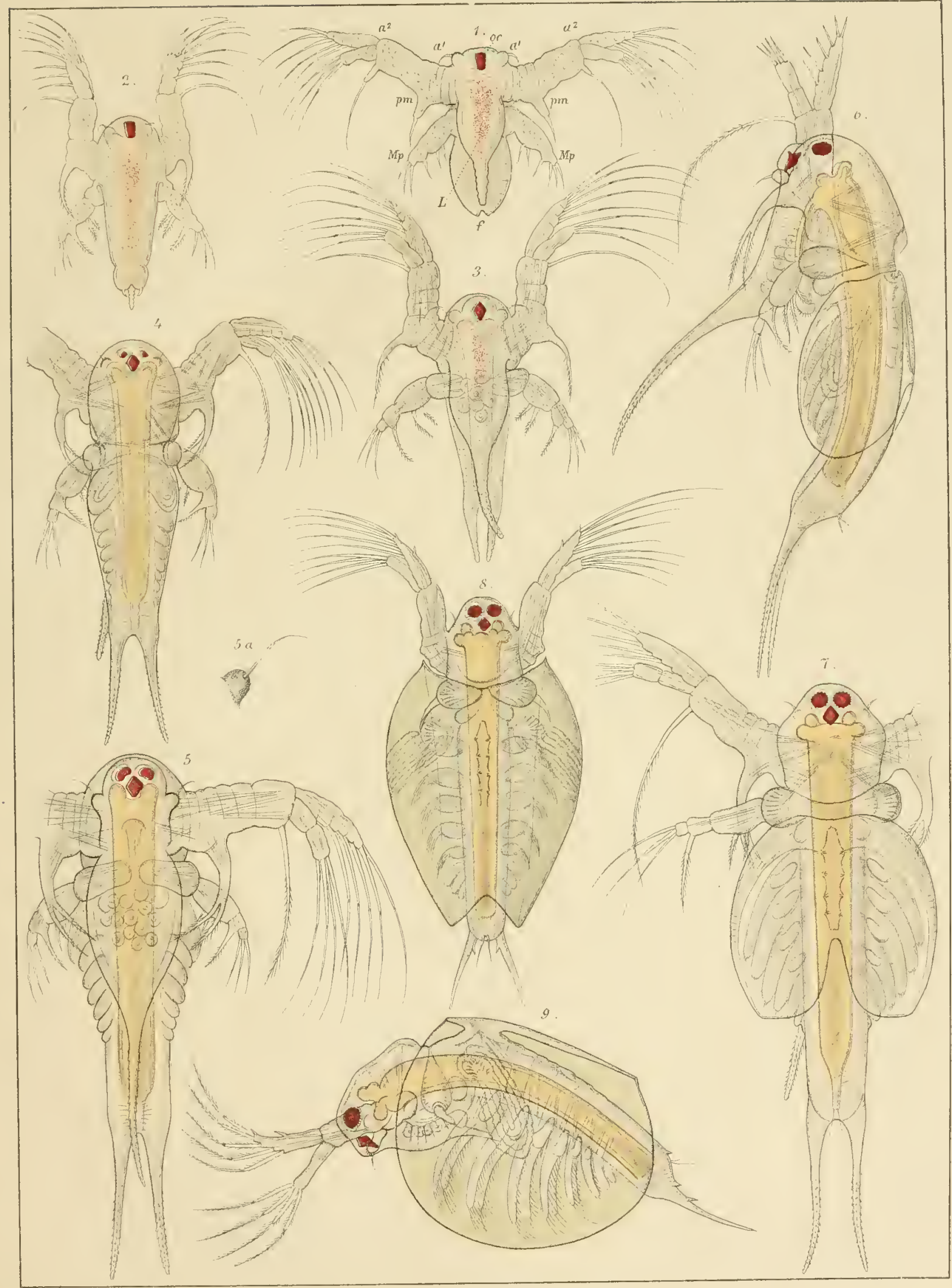

Limnadia Tenticutaris (Lin.). 



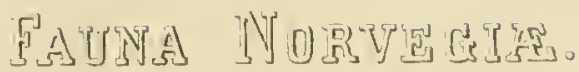

(Crustacea)

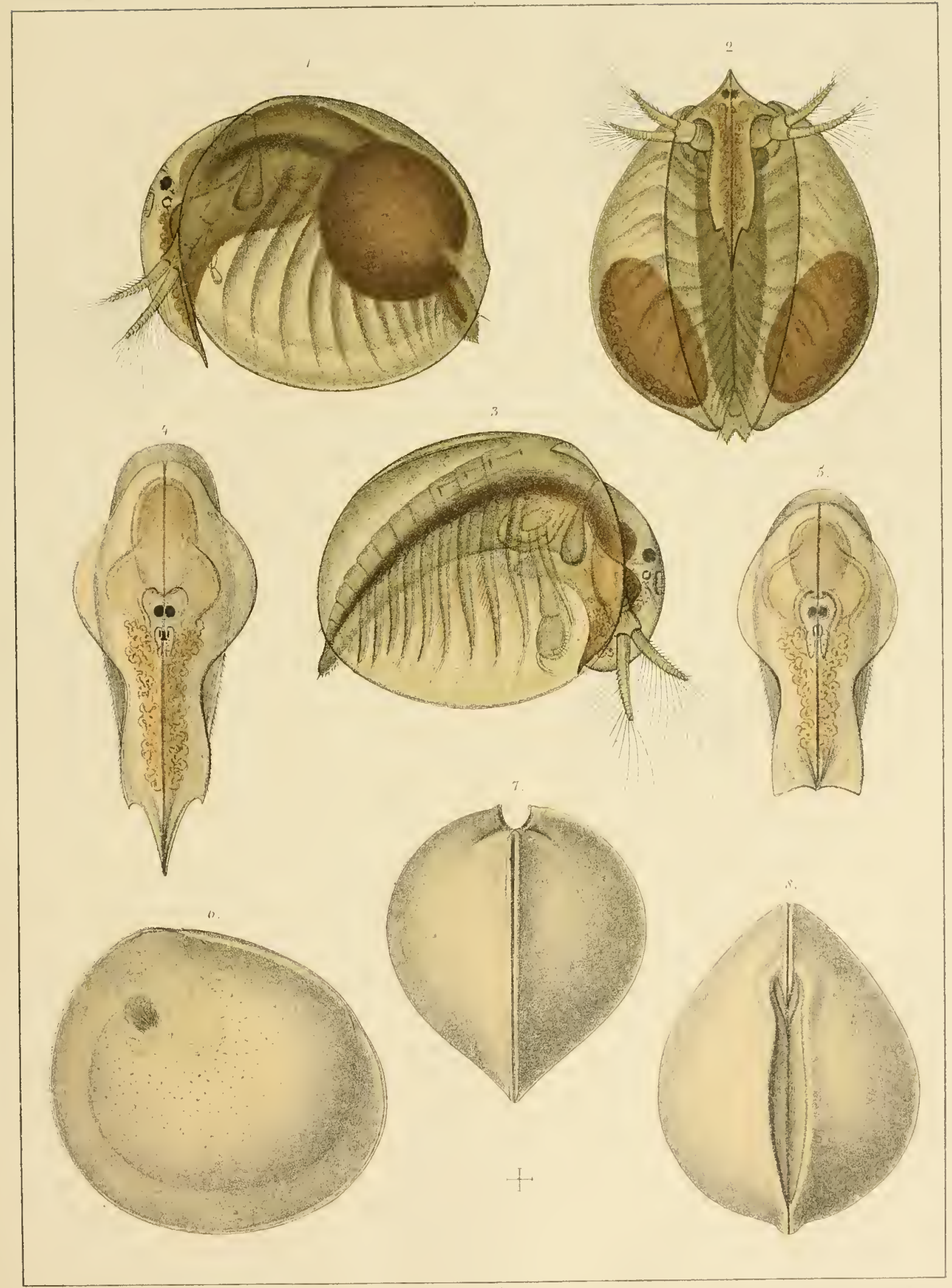





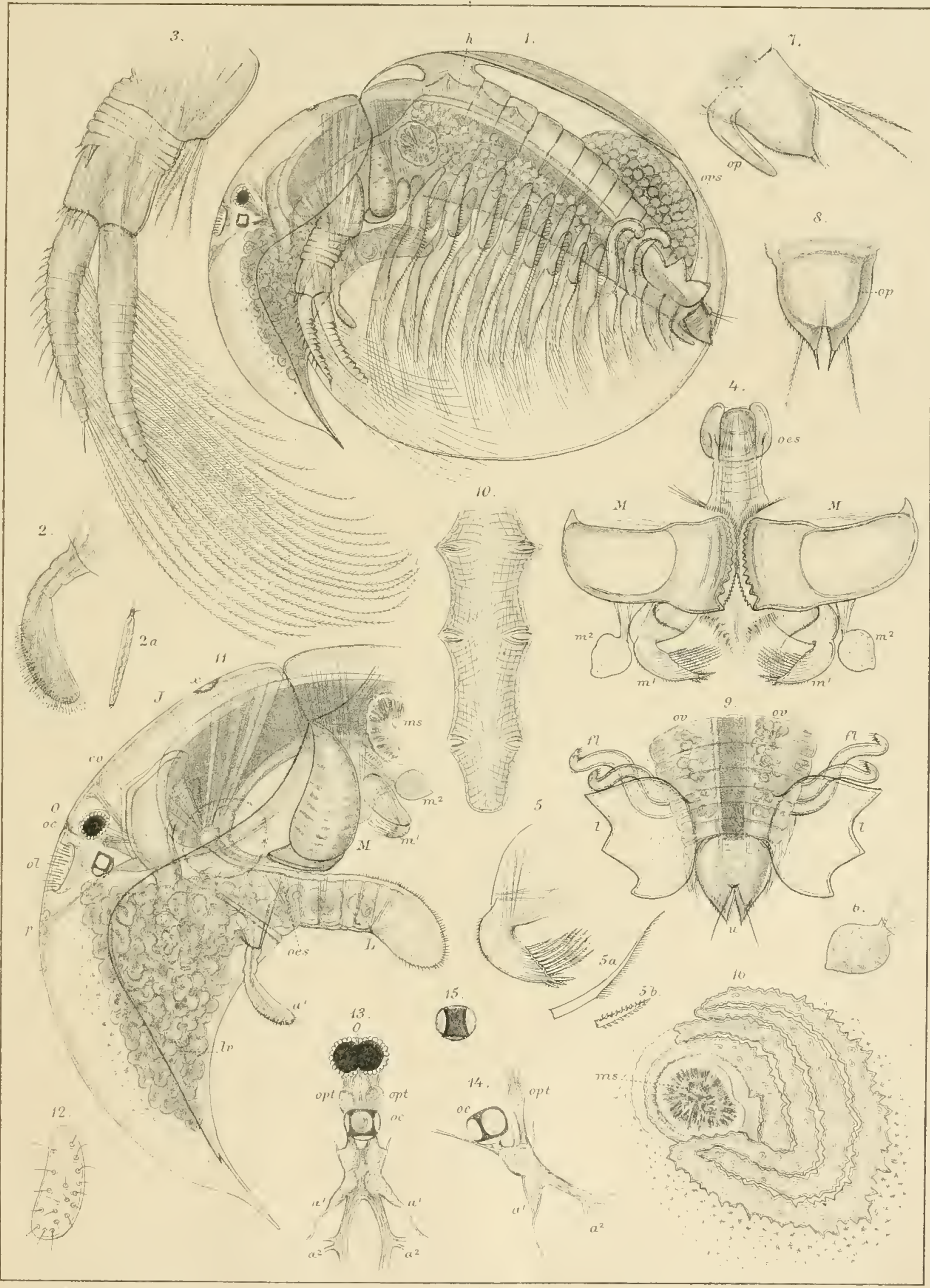





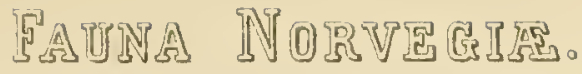

(Crustacea)

Tab XX

Phyllop . Za

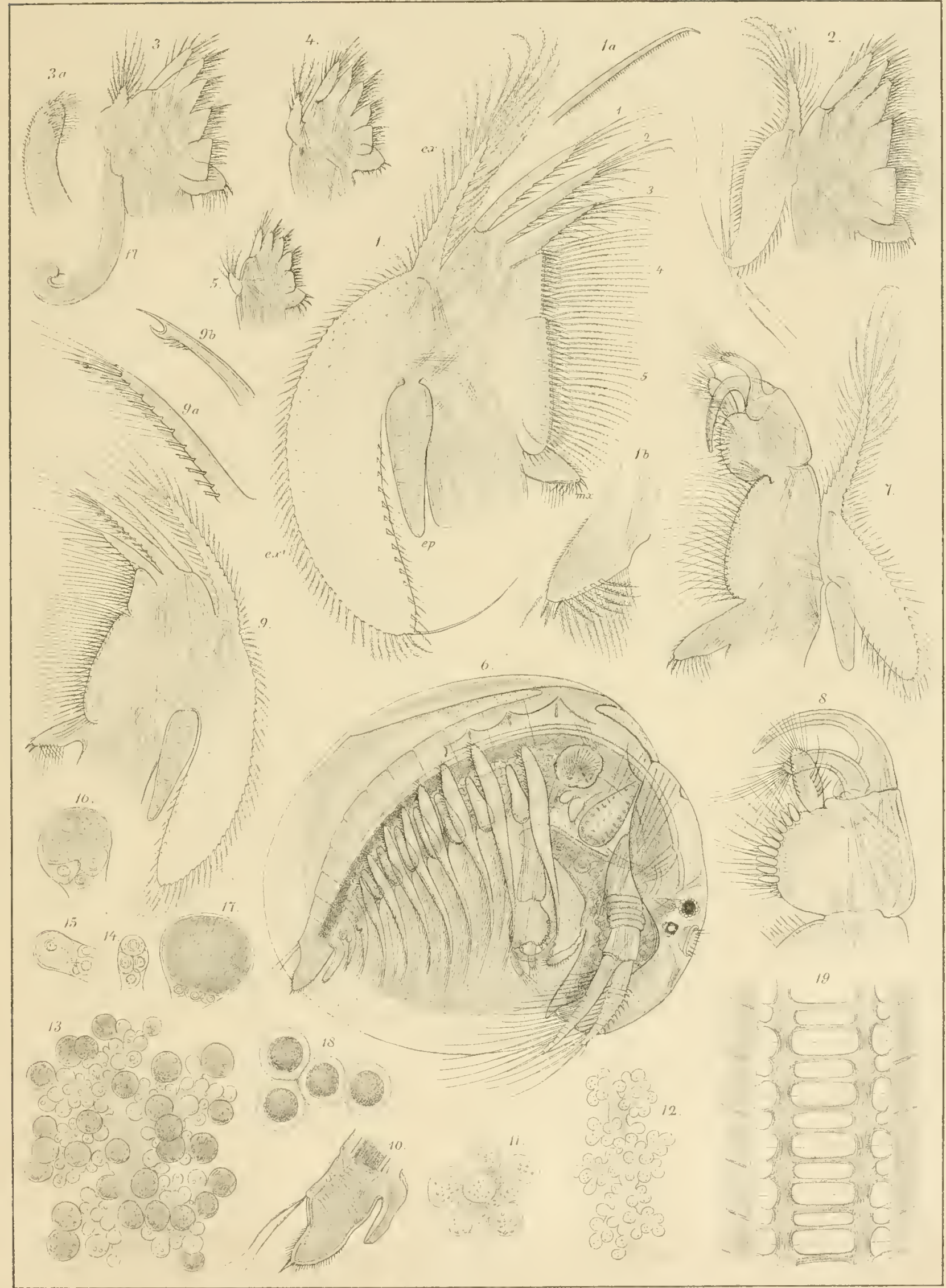

Lir $\int$ tis brarhyura, (ä̈ller) 


